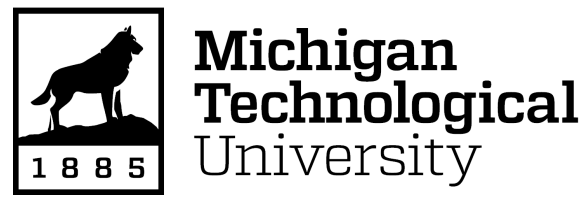

Michigan Technological University Digital Commons @ Michigan Tech

Dissertations, Master's Theses and Master's Reports

2019

\title{
AN EXPERIMENTAL STUDY OF A PASSIVE NOx ADSORBER (PNA) FOR THE REDUCTION OF COLD START DIESEL EMISSIONS
}

Conor Berndt

Michigan Technological University, ctberndt@mtu.edu

Copyright 2019 Conor Berndt

Recommended Citation

Berndt, Conor, "AN EXPERIMENTAL STUDY OF A PASSIVE NOx ADSORBER (PNA) FOR THE REDUCTION OF COLD START DIESEL EMISSIONS", Open Access Master's Thesis, Michigan Technological University, 2019.

https://doi.org/10.37099/mtu.dc.etdr/936

Follow this and additional works at: https://digitalcommons.mtu.edu/etdr

Part of the Automotive Engineering Commons 
AN EXPERIMENTAL STUDY OF A PASSIVE NOx ADSORBER (PNA) FOR THE REDUCTION OF COLD START DIESEL EMISSIONS

By

Conor T. Berndt

A THESIS

Submitted in partial fulfillment of the requirements for the degree of MASTER OF SCIENCE

In Mechanical Engineering

MICHIGAN TECHNOLOGICAL UNIVERSITY

2019

(C) 2019 Conor T. Berndt 
This thesis has been approved in partial fulfillment of the requirements for the Degree of MASTER OF SCIENCE in Mechanical Engineering.

$$
\text { Department of Mechanical Engineering - Engineering Mechanics }
$$

Thesis Co-Advisor: Dr. Jeffrey D. Naber

Thesis Co-Advisor: Dr. John H. Johnson

Committee Member: Dr. Boopathi S. Mahadevan

Department Chair: Dr. William Predebon 


\section{Table of Contents}

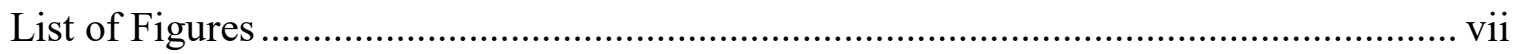

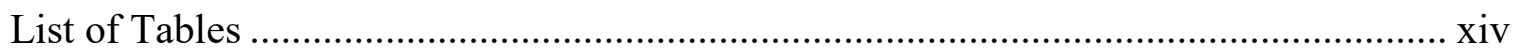

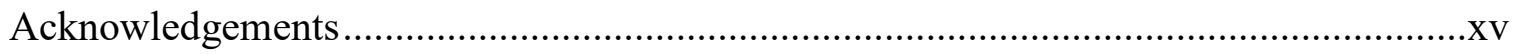

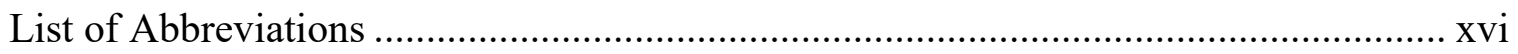

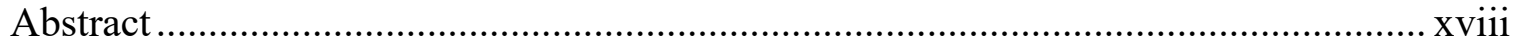

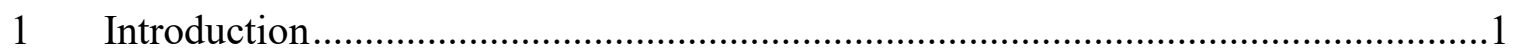

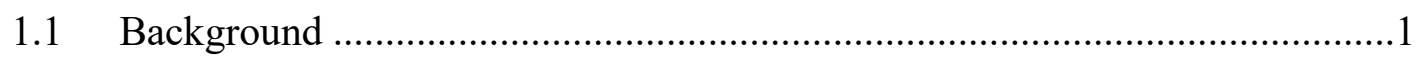

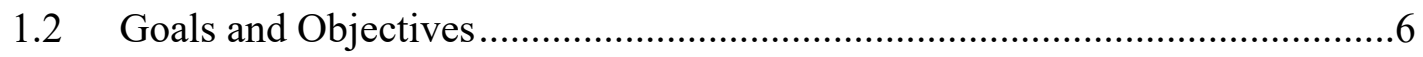

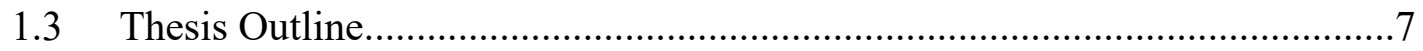

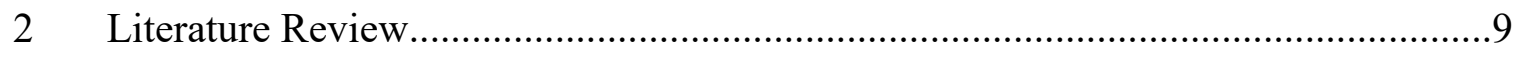

2.1 Ultra-Low NOx Aftertreatment Systems ....................................................

2.2 PNA Fundamentals...............................................................................

2.3 PNA, DOC, and Cold Start Concept Catalyst Performance............................15

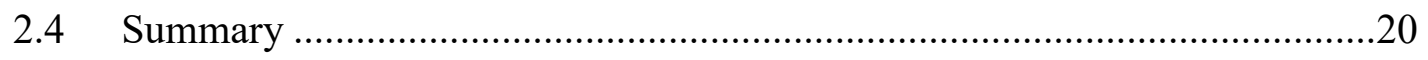

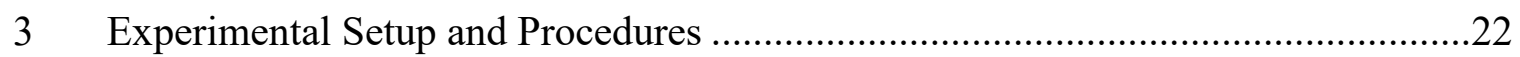

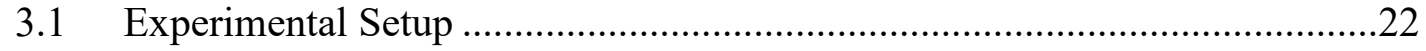

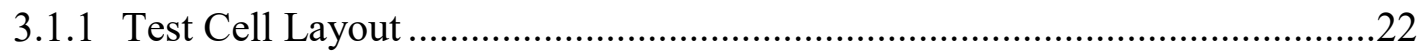

3.1.2 Engine and Dynamometer ......................................................................24

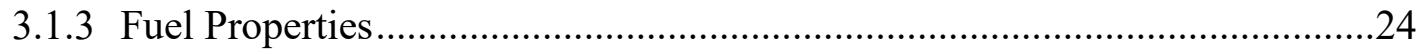

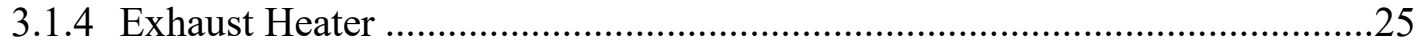




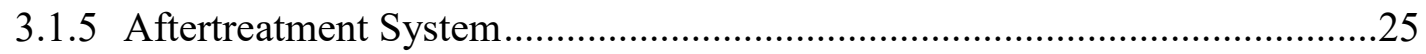

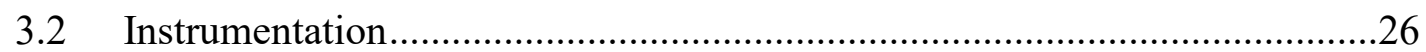

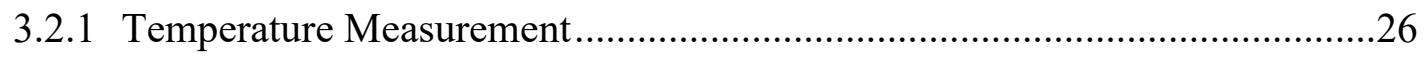

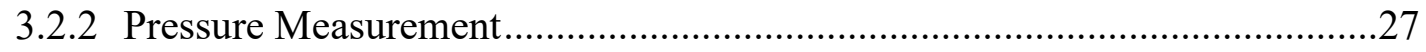

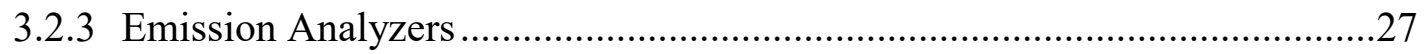

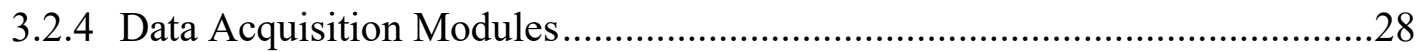

3.3 Test Procedures and Experimental Conditions ............................................28

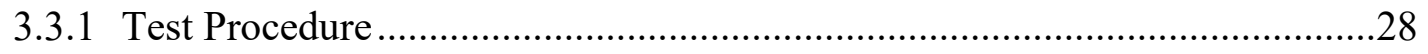

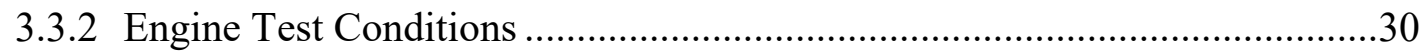

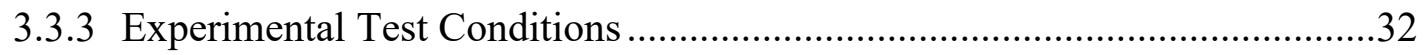

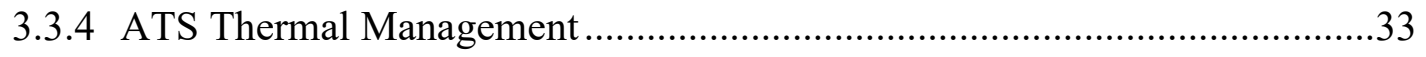

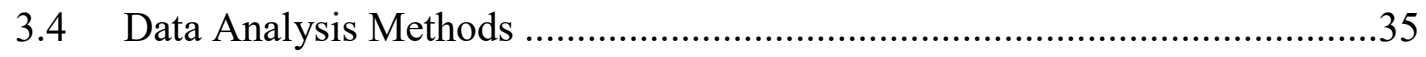

3.4.1 Adsorption and Desorption Calculations (Storage/Release) ............................35

3.4.2 Calculation of $\mathrm{NO}_{2}$ to NOx Ratio (NO Conversion Efficiency) .....................38

3.4.3 Calculation of dCSC ${ }^{\mathrm{TM}}$ Volume Weighted Temperature ..................................39

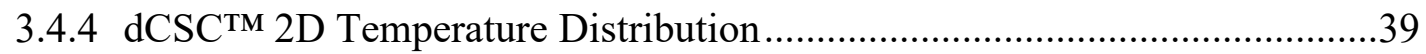

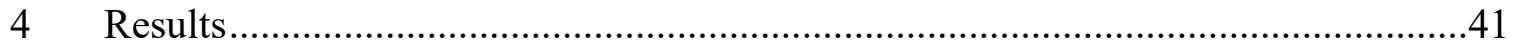

4.1 Test Phases III and IV Emissions Data ………………..............................42

4.2 $\mathrm{NO}, \mathrm{NO}_{2}$, and $\mathrm{NOx}$ Storage Performance ....................................................4

$4.3 \mathrm{NO}, \mathrm{NO}_{2}$, and $\mathrm{NOx}$ Release Performance....................................................52

4.4 $\mathrm{NO}$ to $\mathrm{NO}_{2}$ Oxidation Characteristics ..........................................................5

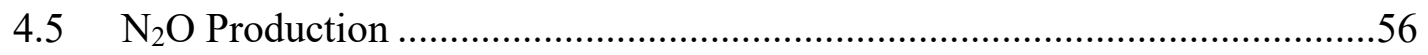

4.6 CO Storage/Oxidation Performance ............................................................57 
4.7 2D Temperature Distributions ..................................................................60

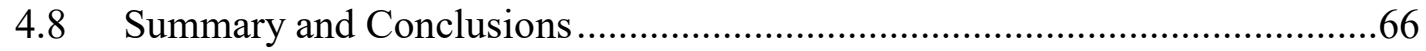

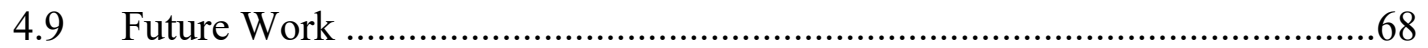

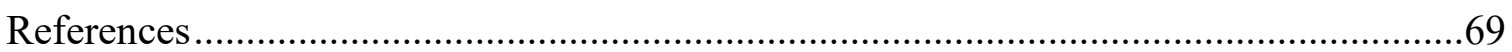

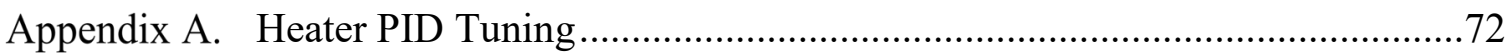

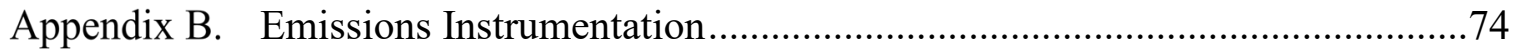

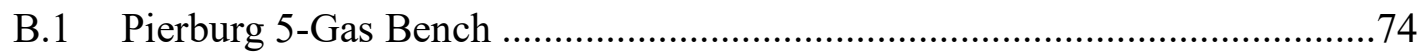

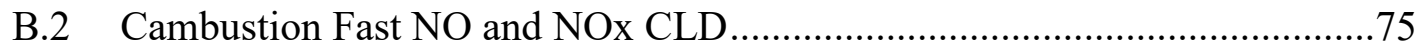

B.3 Cambustion HFR 400 Fast FID ................................................................

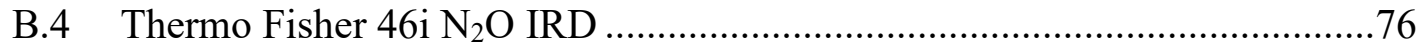

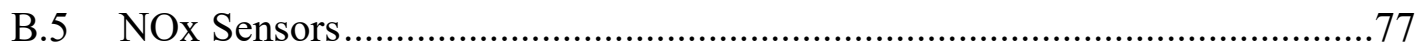


Appendix C. Paragon ULSD \#2 Fuel Analysis Results

Appendix D. Experimental Testing Matrix ……………............................................79

Appendix E. Calculation of dCSC ${ }^{\mathrm{TM}}$ Volume Weighted Temperature ...........................80

Appendix F. Emissions Timeplots During Testing......................................................82

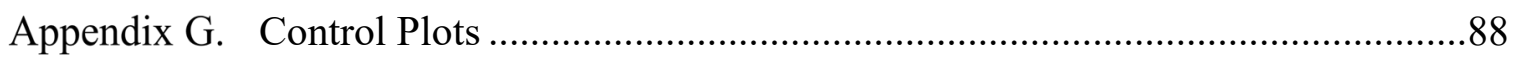

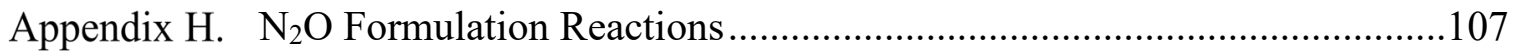

Appendix I. CO, HC, and NO Oxidation Reactions ……….....................................108

Appendix J. Additional Substrate Thermocouples.......................................................109

Appendix K. Copyright Documentation.................................................................110

K.1. Figure 1.1 Possible ULN ATS Compared to Current ATS ............................110

K.2. Copyright Permission for Thesis Figure 1.2 Turbine Outlet Temperature vs.

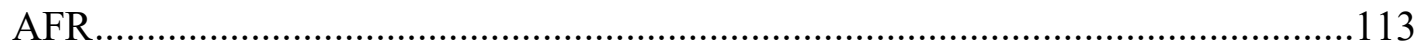

K.3. Copyright Permission for Thesis Figure 2.2 NOx Adsorption/Storage, Figure 2.3 NOx Desorption/Release, and Figure 2.4 Effects of $\mathrm{H}_{2} \mathrm{O}$ on NOx adsorption.116 K.4. Copyright Permission for Thesis Figure 2.1 ULN ATS used on a Volvo MY 13.0L Diesel Engine at SwRI

K.5. Copyright Permission for Thesis Figure $2.5 \mathrm{dCSC}^{\mathrm{TM}}$ and DOC oxidation performance, Figure 2.6 CO Oxidation Comparison of DOC, PNA, and dCSCTM, and Figure 2.7 HC adsorption, desorption, and conversion catalyst comparison...122 K.6. Copyright Permissions for Thesis Figure 2.8 200-Second dCSC ${ }^{\text {тM NOx }}$ Storage Capacity 


\section{List of Figures}

Figure 1.1 Possible ULN ATS Compared to Current ATS [9] ...........................................

Figure 1.2 Engine Turbo Outlet Temperature vs. AFR [11].............................................

Figure 2.1 ULN ATS used on a Volvo MY 13.0L Diesel Engine at SwRI [5] ...................

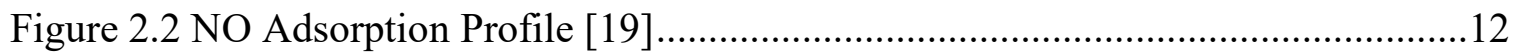

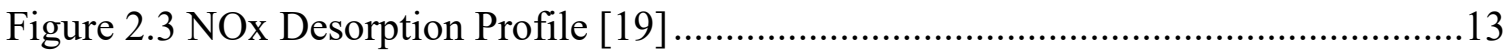

Figure 2.4 $\mathrm{H}_{2} \mathrm{O}$ Effects on NOx Storage Capacity [19] ...............................................14

Figure 2.5 Downstream DOC, PNA, and $\mathrm{dCSC}^{\mathrm{TM}} \mathrm{CO}$ Concentrations vs. Time and

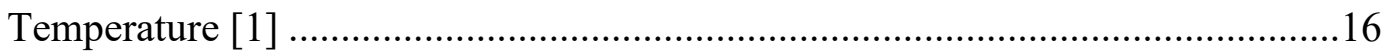

Figure 2.6 Downstream DOC, PNA, and $\mathrm{dCSC}^{\mathrm{TM}} \mathrm{HC}$ Concentrations vs. Time and

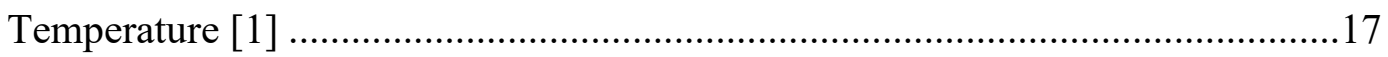

Figure 2.7 Downstream dCSC ${ }^{\mathrm{TM}}$ and $\mathrm{DOC} \mathrm{NO}_{2} / \mathrm{NOx}$ Ratio vs. Temperature [1]............18

Figure 2.8 200-Second dCSCTM NOx Storage Capacity vs. Temperature [8]...................20

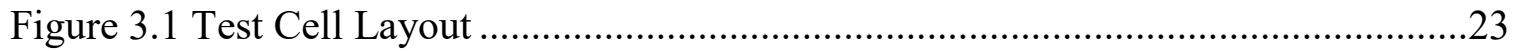

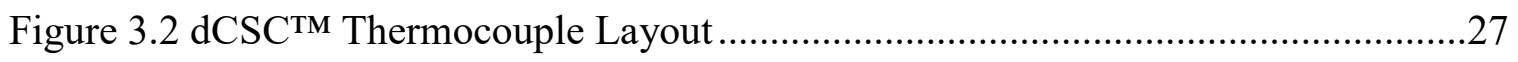

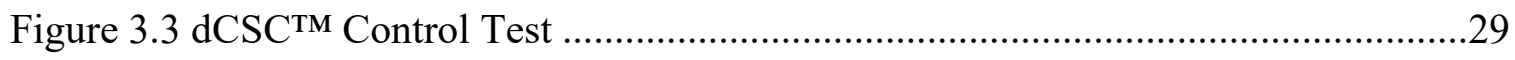

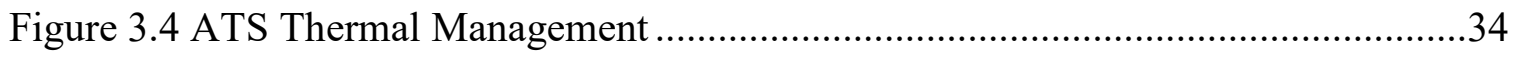

Figure 3.5 dCSC ${ }^{\text {TM }}$ Exhaust Temperatures During a Control Test ....................................35

Figure 3.6 Downstream dCSC ${ }^{\mathrm{TM}} \mathrm{NO}, \mathrm{NO}_{2}$, and NOx Concentrations during a $200{ }^{\circ} \mathrm{C}$

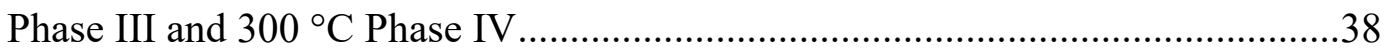


Figure 3.7 Control Test 15 at minute $115, \mathrm{dCSC}^{\mathrm{TM}}$ Temperature $200^{\circ} \mathrm{C}$, Phase III 2D Temperature Distribution

Figure 4.1 NO, $\mathrm{NO}_{2}, \mathrm{NOx}, \mathrm{CO}$, and $\mathrm{N}_{2} \mathrm{O}$ Concentrations Downstream of the dCSC ${ }^{\mathrm{TM}}$ during a $115^{\circ} \mathrm{C}$ Phase III and a $300{ }^{\circ} \mathrm{C}$ Phase IV, at Engine Condition 1

Figure 4.2 Upstream dCSCTM NOx Concentrations vs. Test Order .45

Figure 4.3 Downstream dCSC ${ }^{\mathrm{TM}}$ NOx Concentrations vs. Time during a $115^{\circ} \mathrm{C}$ Phase III and $300^{\circ} \mathrm{C}$ Phase IV, at Engine Condition 1 .46

Figure 4.4 Control Test $200{ }^{\circ} \mathrm{C}$ Phase III dCSC ${ }^{\text {TM }}$ Total NOx Stored vs. Test Order ......48

Figure 4.5 Control Test $200{ }^{\circ} \mathrm{C}$ Phase III NOx Storage Comparison, at Engine Condition 1.

Figure 4.6 Control Test $200^{\circ} \mathrm{C}$ Phase III 200-second dCSC ${ }^{\text {TM }}$ NOx Storage Capacity vs.

Test Order .50

Figure 4.7 200-second dCSC ${ }^{\text {TM }}$ NOx Storage Capacity vs. Temperature at all Engine Conditions.

Figure $4.850 \%$ dCSCTM NOx Storage Capacity vs. Temperature .52

Figure 4.9 dCSC ${ }^{\text {TM }}$ Total NOx Released vs. Temperature .53

Figure $4.10 \mathrm{dCSC}^{\mathrm{TM}}$ Percent of Stored NOx Released vs. Temperature. .54

Figure 4.11 Downstream dCSC ${ }^{\mathrm{TM}} \mathrm{NO}_{2} / \mathrm{NOx}$ Ratio vs. Temperature .56

Figure $4.12 \mathrm{~N}_{2} \mathrm{O}$ Concentration vs. Time during an $80{ }^{\circ} \mathrm{C}$ Phase III and a $300{ }^{\circ} \mathrm{C}$ Phase IV, at Engine Condition 3 .57

Figure 4.13 Downstream dCSCTM CO vs. Time during a $125^{\circ} \mathrm{C}$ Phase $\mathrm{III}$ and $300{ }^{\circ} \mathrm{C}$ Phase IV, at Engine Condition 3 
Figure $4.14 \mathrm{dCSC}{ }^{\mathrm{TM}} \mathrm{CO}$ Storage/Oxidation Efficiency vs. Time during a $125^{\circ} \mathrm{C}$ Phase III and $300{ }^{\circ} \mathrm{C}$ Phase IV, at Engine Condition 1

Figure 4.15 Downstream dCSCTM CO Oxidation \% vs. Temperature .60

Figure 4.16 Control Test 13 at minute 113 , dCSC ${ }^{\mathrm{TM}}$ Temperature $200{ }^{\circ} \mathrm{C}$, Phase III 2D Temperature Distribution 61

Figure 4.17 Test 9 minute 103 , dCSC ${ }^{\text {TM }}$ Temperature $115^{\circ} \mathrm{C}$, Phase III 2D Temperature Distribution .62

Figure 4.18 Control Test 13 at minute $119, \mathrm{dCSC}^{\mathrm{TM}}$ Temperature Approximately $250^{\circ} \mathrm{C}$, Phase IV Heating (from 200 to $300^{\circ} \mathrm{C}$ ) 2D Temperature Distribution. .63

Figure 4.19 Test 9 minute $112, \mathrm{dCSC}$ TM Temperature Approximately $175^{\circ} \mathrm{C}$, Phase IV Heating (from 115 to $300{ }^{\circ} \mathrm{C}$ ) 2D Temperature Distribution .64

Figure 4.20 Control Test 13 at minute 149 , dCSCTM Temperature $300^{\circ} \mathrm{C}$, Phase IV Release 2D Temperature Distribution .65

Figure 4.21 Test 9 minute $140, \mathrm{dCSC}^{\mathrm{TM}}$ Temperature $300^{\circ} \mathrm{C}$, Phase IV Release 2D

Temperature Distribution .66

A.1 Watlow Heater Temperature Data Showing Oscillating Response .72

A.2 Watlow Heater Temperature Response Data After Tuning .73

B.1 Downstream dCSCTM NOx Sample Locations. . .75

B.2 Cambustion fNO400 CLD NOx Channel Setup .76

B.3 $\mathrm{N}_{2} \mathrm{O}$ Analyzer $\mathrm{CO}_{2}$ Concentration Interference .77

F.1 Control Test dCSC ${ }^{\mathrm{TM}}$ Delta Pressure during Test Phases I-IV . .82

F.2 Control Test dCSC ${ }^{\text {TM }}$ Temperature during Test Phases I-IV .82 
F.3 Downstream dCSC ${ }^{\mathrm{TM}} \mathrm{CO}$ Concentration during a $200{ }^{\circ} \mathrm{C}$ Test Phase III and $300{ }^{\circ} \mathrm{C}$

Phase IV, at Engine Condition 1

F. 4 dCSC ${ }^{\text {TM }}$ CO Storage/Oxidation Efficiency during a $200{ }^{\circ} \mathrm{C}$ Test Phase III and $300{ }^{\circ} \mathrm{C}$

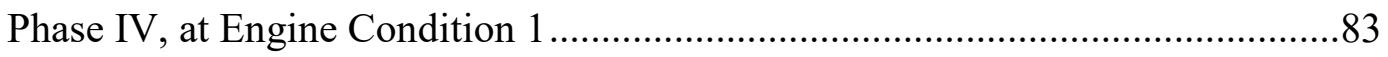

F.5 Downstream dCSC ${ }^{\mathrm{TM}} \mathrm{CO}_{2}$ Concentration during a $200{ }^{\circ} \mathrm{C}$ Test Phase III and $300{ }^{\circ} \mathrm{C}$

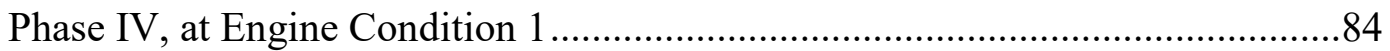

F.6 Downstream dCSC ${ }^{\mathrm{TM}} \mathrm{CO}_{2}$ Concentration during a $200{ }^{\circ} \mathrm{C}$ Test Phase III and $300{ }^{\circ} \mathrm{C}$

Phase IV, at Engine Condition 1 .........................................................................

F.7 Downstream dCSC ${ }^{\mathrm{TM}} \mathrm{NO}, \mathrm{NO}_{2}$, and NOx Concentrations during a $200{ }^{\circ} \mathrm{C}$ Test Phase III and $300{ }^{\circ} \mathrm{C}$ Phase IV, at Engine Condition 1 ................................................85

F. 8 Downstream dCSC ${ }^{\mathrm{TM}}$ NOx Sensor Concentrations during a $200^{\circ} \mathrm{C}$ Test Phase III and

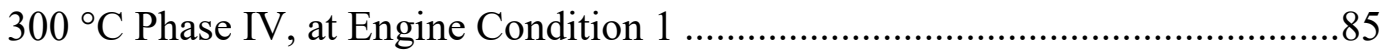

F.9 Downstream dCSC ${ }^{\text {TM }}$ Cambustion CLD NO, $\mathrm{NO}_{2}$, and $\mathrm{NOx}$ Concentrations during a $200{ }^{\circ} \mathrm{C}$ Test Phase III and $300^{\circ} \mathrm{C}$ Phase IV, at Engine Condition 1 .....................86

F.10 Downstream dCSC ${ }^{\mathrm{TM}}$ NOx Concentrations during a $200{ }^{\circ} \mathrm{C}$ Test Phase III and 300 ${ }^{\circ} \mathrm{C}$ Phase IV, at Engine Condition 1 .86

F.11 Engine Load and Speed, Turbo Outlet Temperature, and C1 Thermocouple Temperature during a $200{ }^{\circ} \mathrm{C}$ Test Phase III and $300{ }^{\circ} \mathrm{C}$ Phase IV, at Engine Condition 1 .87

F.12 Downstream dCSC ${ }^{\text {TM }}$ Brake Specific NOx during a $200{ }^{\circ} \mathrm{C}$ Test Phase III and 300 ${ }^{\circ} \mathrm{C}$ Phase IV, at Engine Condition 1

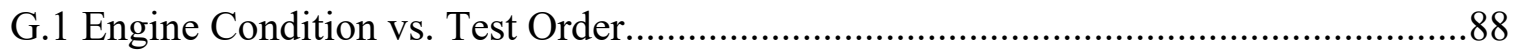

G.2 Upstream dCSC ${ }^{\text {TM }}$ NO/NOx Ratio vs. Test Order .89 
G.3 Upstream dCSC ${ }^{\text {тм }}$ NOx Sensor NOx Concentration vs. Test Order

G.4 Upstream dCSC ${ }^{\text {TM }} \mathrm{NOx}$ Sensor $\mathrm{O}_{2}$ Concentration vs. Test Order .90

G.5 Upstream dCSC ${ }^{\text {TM }}$ Pierburg NO Concentration vs. Test Order..... .90

G.6 Upstream dCSC ${ }^{\mathrm{TM}}$ Pierburg $\mathrm{NO}_{2}$ Concentration vs. Test Order .91

G.7 Upstream dCSC ${ }^{\text {TM }}$ Pierburg NOx Concentration vs. Test Order .91

G.8 Upstream dCSC ${ }^{\text {TM }}$ Pierburg CO Concentration vs. Test Order..... .92

G.9 Upstream dCSC ${ }^{\text {TM }}$ Pierburg $\mathrm{CO}_{2}$ Concentration vs. Test Order

G.10 Upstream dCSC ${ }^{\text {тм }}$ Pierburg $\mathrm{O}_{2}$ Concentration vs. Test Order .....

G.11 Test Cell Barometric Pressure vs. Test Order...... .93

G.12 Test Cell Relative Humidity vs. Test Order. .94

G.13 Average Test Cell Temperature during Test vs. Test Order .94

G.14 dCSC ${ }^{\text {TM }}$ Delta Pressure vs. Average Volume Weighted Temperature .95

G.15 Engine Intake and dCSC ${ }^{\text {TM }}$ Delta Pressures vs. Test Order. .95

G.16 AFR Calculated from Fuel and Air Flow Rates vs. Test Order .96

G.17 AFR Calculated from $\mathrm{O}_{2}$ and $\mathrm{CO}_{2}$ vs. Test Order .96

G.18 Comparison of all AFR Calculations vs. Test Order ....

G.19 Upstream dCSC ${ }^{\text {TM }}$ NOx Sensor $\mathrm{O}_{2}$ Concentration vs. Test Order ........

G.20 Engine Turbo Outlet Temperature vs. Test Order . .98

G.21 Engine Inlet Air Density vs. Test Order .98 
G.22 Coriolis Fuel Flow Meter (LabVIEW) and Calculated (Calterm) Fuel Flow Rate vs.

Test Order

G.23 Laminar Flow Element Engine Intake Air Mass Flow Rate vs. Test Order

G.24 Engine Exhaust Mass Flow Rate Measured (LabVIEW) and Calculated (Calterm) vs. Test Order .100

G.25 Engine Air Mass Flow Rate Measured (LabVIEW) and Calculated (Calterm) vs.

Test Order

G.26 Engine Intake Boost (Calterm) vs. Test Order.

G.27 Engine EGR Position (Calterm) vs. Test Order.

G.28 Engine EGR Flow Rate (Calterm) vs. Test Order

G.29 Engine Coolant Temperature (LabVIEW and Calterm) vs. Test Order

G.30 Engine Variable Geometry Turbo Position (Calterm) vs. Test Order

G.31 Engine Accelerator Pedal Position (Calterm) vs. Test Order

G.32 Engine Load vs. Test Order

104

G.33 Engine Speed vs. Test Order.

G.34 Engine Out $\mathrm{H}_{2} \mathrm{O}$ Concentration Calculated from LabVIEW Flowrate AFR vs. Test

Order 105

G.35 Engine Out $\mathrm{H}_{2} \mathrm{O}$ Concentration Calculated from Calterm Flowrate AFR vs. Test

Order

G.36 Engine Out $\mathrm{H}_{2} \mathrm{O}$ Concentration Calculated from Pierburg Engine Out $\mathrm{CO}_{2}$

Concentration vs. Test Order. 106 


\section{G.37 Engine Out $\mathrm{H}_{2} \mathrm{O}$ Concentration Calculated from Pierburg Engine Out $\mathrm{O}_{2}$}

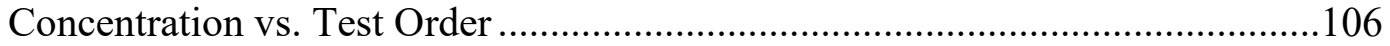

J.1 Recommended Additional Thermocouples to Measure Temperature..........................109 


\section{List of Tables}

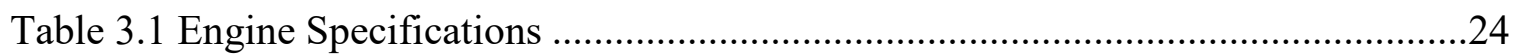

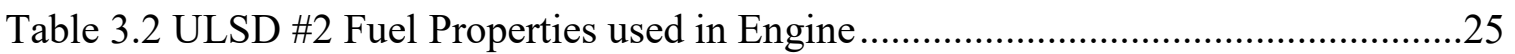

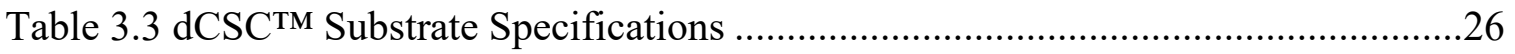

Table 3.4 Engine Test Conditions.................................................................................

Table 3.5 Emissions Storage Test Plan.........................................................................32

Table 3.6 Emissions Release/Conversion Test Plan ........................................................32

Table 3.7 Emissions Release/Conversion vs. Temperature Ramp Test Plan .....................33

Table B.1 Pierburg 5-Gas Bench Analyzer Types...........................................................74

Table C.1 Paragon ULSD \#2 Fuel Analysis Results ........................................................78

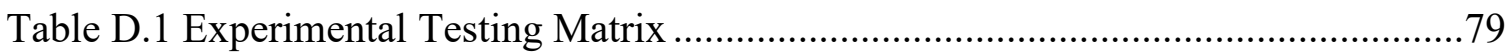




\section{Acknowledgements}

Many organizations and individuals made it possible for me to pursue this higher education and supported me throughout. I would like to thank those past and present who are responsible for this accomplishment.

I would like to thank my advisors Dr. Jeffrey Naber and Dr. John Johnson for their continued support and expertise throughout my research. Also, for providing me with the opportunity to continue my education and gain such a valuable experience. I would like to thank Dr. Boopathi S. Mahadevan for being on the committee for my defense. Dr. Scott Miers for his invaluable teaching influence on my undergraduate studies. Dr. Darrel Robinette, for being an excellent professor during my undergraduate degree and influencing me to pursue my master's degree. Zachary Stanchina, William Hansley, and Tyler Miller for assisting with the experimental testing. Henry Schmidt and Bill Atkinson for hiring me at the Michigan Tech AERB and helping me obtain a graduate research assistantship. Andreas from AVL for his support with the Pierburg 5-gas bench. Xiaobo Song from Cummins for supplying software licensure and replacement engine instrumentation. Paul Dice, for his support with the engine test cell, and many others.

I would also like to thank Tucker Alsup for working with me to design and construct the experimental test setup and to conduct experimental testing. Without his help I can honestly say I would not be here and for that I am grateful.

I would also like to thank my friends and family for their unconditional support and encouragement throughout these past two years.

For GRA financial support and support for the research conducted I would like to thank the MTU Diesel Engine Aftertreatment Consortium. The consortium partners being Cummins and Isuzu. 


\section{List of Abbreviations}

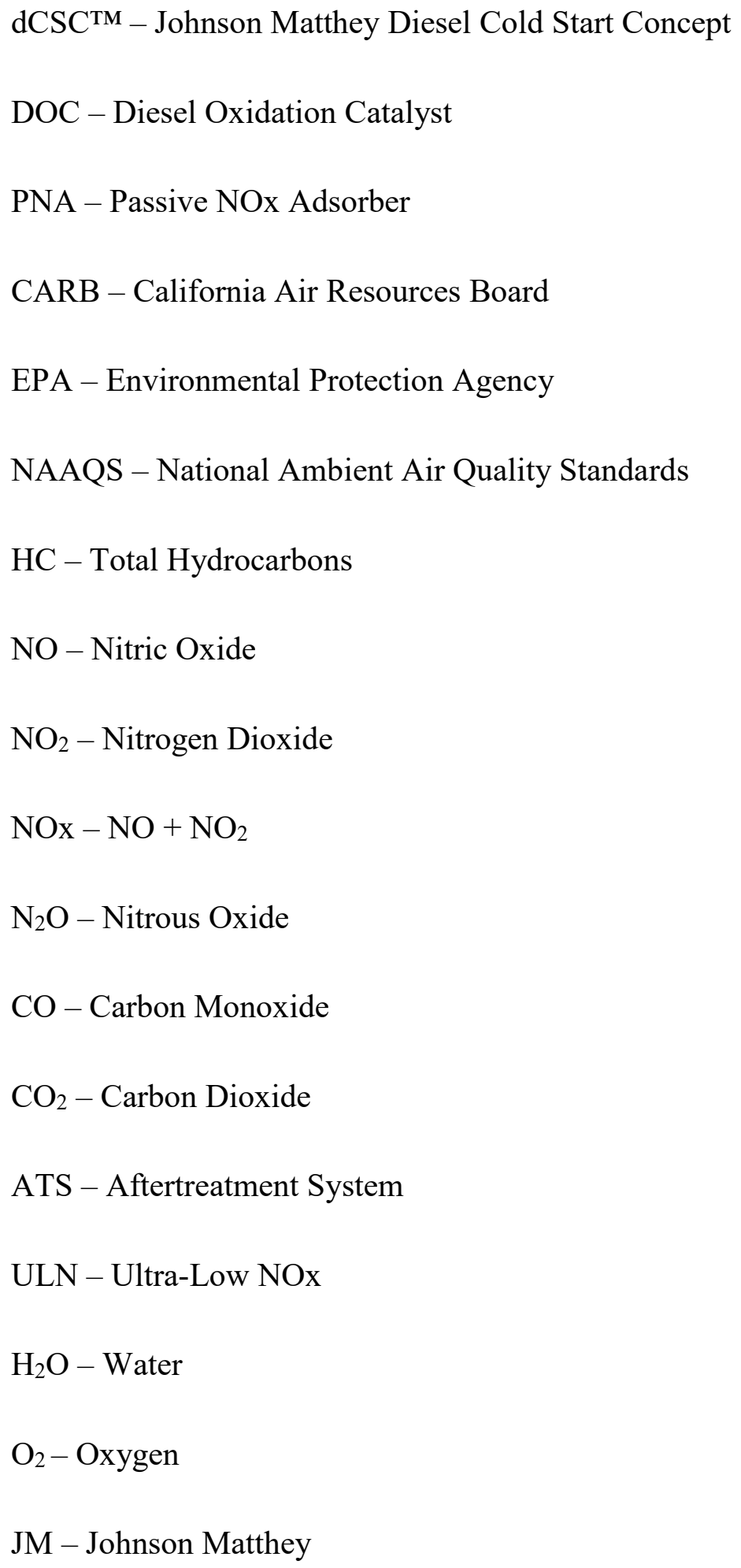


SCR - Selective Catalytic Reduction

SCR-F - Selective Catalytic Reduction Catalyst on a Diesel Particulate Filter

EGR - Exhaust Gas Recirculation

DPF - Diesel Particulate Filter

CPF - Catalyzed Particulate Filter

PM - Particulate Matter

CDA - Cylinder Deactivation

SwRI - Southwest Research Institute

LLC - Low Load Cycle

REAL - Real Emissions Assessment Logging

$\mathrm{NI}$ - National Instruments ${ }^{\mathrm{TM}}$

DAQ - Data Acquisition

VGT - Variable Geometry Turbo

AFR - Air-to-Fuel Ratio

GHG - Greenhouse Gas

PGM - Platinum Group Metals

Ar - Argon

Pd - Palladium

Pt - Platinum 


\section{Abstract}

Medium and heavy-duty diesel engines contribute nearly a third of all NOx emissions nationwide. Further reduction of NOx emissions from medium and heavy-duty diesel engines is needed in order to meet National Ambient Air Quality Standards (NAAQS) for ambient particulate matter and ozone. Current diesel engine aftertreatment systems are very efficient at reducing NOx emissions at exhaust temperatures above $200{ }^{\circ} \mathrm{C}$, however at exhaust temperatures below $200{ }^{\circ} \mathrm{C}$ there are significant NOx emissions at the tailpipe. Therefore, a reduction of diesel engine cold start and low speed/load operation emissions, where exhaust temperatures are below $200^{\circ} \mathrm{C}$, is needed. Utilizing a passive NOx adsorber (PNA) to adsorb NOx emissions at temperatures below $200^{\circ} \mathrm{C}$ and reduce tailpipe NOx emissions is part of the solution. In this research, over 200 hours of experimental testing was carried out on a Johnson Matthey Diesel Cold Start Concept Catalyst (dCSCTM), a passive NOx adsorber with hydrocarbon trapping ability on an oxidation catalyst.

Storing NOx emissions while the aftertreatment system downstream of the PNA is at temperatures below $200{ }^{\circ} \mathrm{C}$ needs to be supplemented by externally heating the aftertreatment system downstream of the PNA. This would reduce the time the aftertreatment system is at temperatures below $200^{\circ} \mathrm{C}$. The faster the aftertreatment system reaches operating temperature the less risk of substantial NOx emissions at the tailpipe, because the storage capacity of the $\mathrm{dCSC}^{\mathrm{TM}}$ is finite. Methods such as electric heaters, fuel burners, engine calibration, engine hardware changes, and others to quickly reach desired aftertreatment temperatures are being researched. The EPA and CARB are preparing to monitor the emissions regulation compliance of medium and heavy-duty diesel engines by using on-board diagnostics, throughout the useful life of the engine. They are also investigating thermal and chemical catalyst poisoning in order to accurately age and predict the life of the aftertreatment system. Improving processes and reducing contaminants in fuels can reduce the risk of chemical catalyst poisoning. 
A 2013 6.7L Cummins ISB (280 hp) diesel engine was used for a series of experiments to quantify the $\mathrm{NO}, \mathrm{NO}_{2}$, and $\mathrm{NOx}$ storage and release performance of the $\mathrm{dCSC}{ }^{\mathrm{TM}}$. NOx storage experiments were performed at a range of temperatures from 80 to $250{ }^{\circ} \mathrm{C}$ and NOx release experiments were performed at temperatures from 200 to $450{ }^{\circ} \mathrm{C}$. The portion of $\mathrm{NO}, \mathrm{NO}_{2}$, and $\mathrm{NOx}$ that is converted and the portion that remains stored on the $\mathrm{dCSC}^{\mathrm{TM}}$ and the oxidation characteristics of the $\mathrm{dCSC}^{\mathrm{TM}}$ at these temperatures were also quantified.

Peak NOx storage capacity of the $\mathrm{dCSC}^{\mathrm{TM}}$ was found to be at temperatures from 125 to $150{ }^{\circ} \mathrm{C}$. Throughout the testing, a decrease in the total NOx storage capacity was observed. However, the 200-second dCSC ${ }^{\text {TM }}$ NOx storage capacity remained constant throughout testing. The percentage of stored NOx released was observed to be over $70 \%$ if the $\mathrm{dCSC}^{\mathrm{TM}}$ temperature ramped through 200 to $265^{\circ} \mathrm{C}$ and/or reached $350{ }^{\circ} \mathrm{C}$. These temperatures coincide with the desired operating temperatures of current aftertreatment systems. The dCSC ${ }^{\mathrm{TM}}$ also shows over $50 \% \mathrm{NO}$ to $\mathrm{NO}_{2}$ oxidation at temperatures from 200 to $400{ }^{\circ} \mathrm{C}$ and a peak oxidation performance of $90 \%$ at $300{ }^{\circ} \mathrm{C}$. At temperatures of $150{ }^{\circ} \mathrm{C}$ and above, the $\mathrm{dCSC} \mathrm{CM}^{\mathrm{TM}}$ oxides 90 to $100 \%$ of $\mathrm{CO}$ to $\mathrm{CO}_{2}$. At 80 to $125^{\circ} \mathrm{C}$, the dCSC ${ }^{\text {TM }}$ oxidizes 50 to $70 \%$ of the $\mathrm{CO}$ entering the substrate to $\mathrm{CO}_{2}$. 


\section{Introduction}

The purpose of this chapter is to give background information and the goals and objectives of the research conducted. Specifically, why the research is being conducted and what need does it fill. For decades, diesel engine aftertreatment system research has been continuously driven by increasingly stringent emissions standards. The Environmental Protection Agency (EPA) and California Air Resources Board (CARB) have worked in conjunction for years to develop new emissions standards, test cycles, compliance monitoring, useful life determinations, and advanced protocols to simulate real world deterioration of the components in the diesel engine aftertreatment system.

\subsection{Background}

The current heavy-duty diesel engine aftertreatment systems can reduce tailpipe emissions with very high efficiencies once they reach their operating temperature [1]. One such system from Cummins Emissions Solutions consists of (from upstream to downstream) a DOC, DPF, DEF injector, decomposition reactor, and SCR [2]. The DOC, or Diesel Oxidation Catalyst, oxidizes $\mathrm{CO}$ to $\mathrm{CO}_{2}, \mathrm{HC}$ to $\mathrm{CO}_{2}$ and $\mathrm{H}_{2} \mathrm{O}$, and $\mathrm{NO}$ to $\mathrm{NO}_{2}$. The DPF, or Diesel Particulate Filter, filters the particulate matter (PM). The DEF, or Diesel Exhaust Fluid injector injects atomized DEF into the decomposition tube. The decomposition tube decomposes the atomized DEF into ammonia $\left(\mathrm{NH}_{3}\right)$ and water $\left(\mathrm{H}_{2} \mathrm{O}\right)$, and mixes the $\mathrm{NH}_{3}$ uniformly with the exhaust gas. The SCR, or Selective Catalytic Reduction, receives the $\mathrm{NH}_{3}$-exhaust gas mixture and reduces the $\mathrm{NOx}$ in the exhaust gas to nitrogen $\left(\mathrm{N}_{2}\right)$ and water $\left(\mathrm{H}_{2} \mathrm{O}\right)$. There is a need to periodically actively regenerate the DPF due to excess PM by performing a late diesel injection [2]. The efficiency of the SCR catalyst has been increased to $90 \%$ at temperatures as low as $200^{\circ} \mathrm{C}$ [3]. However, when these systems are below $200{ }^{\circ} \mathrm{C}$, during startup or low speed/load operation, their NOx conversion efficiency is low. One of the goals of the EPA and CARB partnership is to reduce or even eliminate these NOx emissions $[3,4,5]$. 
Currently, heavy-duty trucks contribute a third of the NOx emissions produced in California and are projected to contribute a third nationwide by 2025 [3]. Further NOx emissions regulations are required in order for the South Coast Air Basin to achieve the National Ambient Air Quality Standards (NAAQS) requirement for ambient PM and Ozone [3]. NOx emissions are a precursor to PM, this makes them especially important to meeting the NAAQS PM requirement. The current NOx reduction goal is an Ultra-Low NOx (ULN) standard of 0.02 gNOx/bhp-hr on the FTP and RMC-SET cycles [3]. The Federal Test Procedure (FTP) and Supplemental Emission Test Ramped Modal Cycle (RMC-SET) are the drive cycles currently used to certify medium and heavy-duty diesel engines [3]. The drive cycles command sequences of vehicle speed (chassis dynamometer) or engine load (engine dynamometer) and tailpipe emissions are measured. The tailpipe emissions measurements determine whether or not the specific drive cycle emissions regulations are met. Southwest Research Institute (SwRI) is working closely with CARB and the EPA to determine realistically achievable emissions levels for the drive cycles and the methods for doing so. "Per reference [3], SwRI has achieved 0.034 gNOx/bhp-hr NOx level over the FTP and a $0.038 \mathrm{~g} / \mathrm{bhp}-\mathrm{hr}$ NOx level over the RMC-SET [3]". The latest feasibility assessment from the CARB staff is that MY 2024 through 2026 heavy and medium-duty engines could be required to meet 0.05 to $0.08 \mathrm{gNOx} / \mathrm{bhp}-\mathrm{hr}$ on the FTP and RMC cycles [3, 6]. PM emissions standards will also see a reduction to $0.005 \mathrm{~g} / \mathrm{bhp}-\mathrm{hr}$ by MY 2024. MY 2027 will see an even further reduction in NOx emissions levels $[3,6]$. CARB and the EPA have reduction targets for greenhouse gas (GHG) and petroleum use as well. CARB Phase 2 GHG emissions standards will be implemented alongside the NOx and PM regulations in 2021, 2024, and 2027. These Phase $2 \mathrm{GHG}$ emissions standards require a $5.1 \%$ fuel efficiency improvement from the 2017 fuel efficiency levels, by model year 2027 [3].

A new "Low Load Cycle" (LLC) has been developed by SwRI to simulate the low speed and load of "urban tractor and vocational vehicle operations" [3, 7]. The current FTP and RMC-SET cycles fail to capture the low load and speed operation of medium and heavyduty diesel engines. It is important to capture the low speed/load operation because 
exhaust temperatures are low at these conditions: causing the current ATS to be ineffective [3, 7]. The LLC emissions requirements for NOx will be between 1 to 3 times the FTP and RMC-SET requirements (0.05 to 0.24 gNOx/bhp-hr) $[3,6]$.

During low speed/load operation, the ATS temperatures fall well below $200^{\circ} \mathrm{C}$. Increasing exhaust temperatures can be done via engine calibration, hardware, or external heat sources, and can ensure that the ATS temperature is above $200^{\circ} \mathrm{C}$ during startup and normal operation. In addition, improving ATS efficiencies at temperatures below $200^{\circ} \mathrm{C}$ can help reduce low speed/load emissions. This could involve improving the efficiency of current SCR systems at low temperatures; or employing a passive NOx adsorber (PNA) to store NOx emissions at low temperatures. Current ULN ATS solutions employ both the increase in exhaust temperatures and improving catalyst efficiencies at lower temperatures $[1,4,5,8]$.

The main goal of the ULN ATS is to reduce NOx and HC emissions during low load/speed operation and cold start. Storing NOx and HC emissions until the ATS is at operating temperature is a promising strategy. This can be achieved through the use of a PNA catalyst with zeolites to trap $\mathrm{HC}[1,5,8]$. Figure 1.1 shows a schematic of proposed ULN ATS configurations compared to today's ATS systems [9]. The schematic was put together by Daimler Trucks to reflect the proposals from references $[3,5]$. 


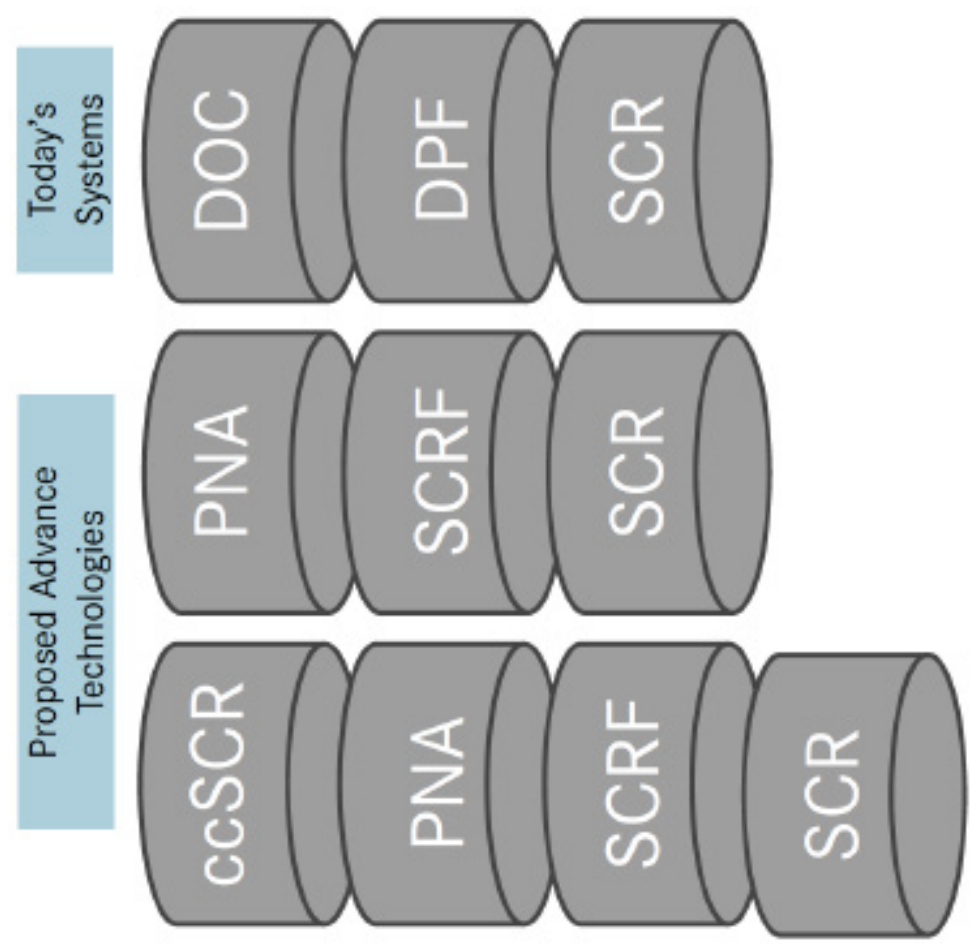

Figure 1.1 Possible ULN ATS Compared to Current ATS [9]

Both "Proposed Advance Technology" systems in Figure 1.1 include the utilization of a PNA to store NOx emissions at temperatures below $200{ }^{\circ} \mathrm{C}[3,5,9]$. PNA technology developed by Johnson Matthey to store HC, CO, and NOx emissions at low temperatures and release them at high temperatures has been developed. The device consists of a PNA with HC trapping ability on an oxidation catalyst i.e. the Diesel Cold Start Concept $\left(\mathrm{dCSC}^{\mathrm{TM}}\right)[1,8]$. The goal of this catalyst is to store emissions while the downstream ATS heats up. Externally heating the downstream ATS will reduce the time the PNA has to adsorb NOx, HC, and CO emissions and improve ATS efficiency [4, 5, 9]. Once the downstream ATS is at its operating temperature, the $\mathrm{dCSC}^{\mathrm{TM}}$ will release these emissions to the downstream ATS to be reduced and oxidized [5,8]. The ATS will have a complex control system that will require accurate thermal management in order to achieve desired tailpipe emissions [10].

The dCSC ${ }^{\text {TM }}$ has a limited NOx and HC storage capacity. Therefore, increasing exhaust temperatures quickly and keeping them above $200^{\circ} \mathrm{C}$ is still a primary goal of the ULN 
ATS. As stated before, exhaust temperatures can be increased through engine calibration, hardware, or external heat sources like electric heaters. Late fuel injections are currently a common tool used to manage the ATS temperature; research is also being done to develop external heat sources such as electric heaters and fuel burners $[3,4,5,10,11]$. Figure 1.2 shows that a reduction in engine AFR increases exhaust gas temperatures [12]. Reducing AFR can be achieved by throttling, reducing boost, valve timing, EGR, and cylinder deactivation $[4,12]$. Some of these are engine hardware changes while some of them are calibration changes will likely be needed. In Figure 1.2 the AFR was decreased through cylinder deactivation and late intake valve closing. A mixture of engine hardware and calibration changes. In this case the figure is reporting turbine outlet temperature which is at the inlet to the ATS. Cases where the turbine outlet temperature falls well below the curve are cases with high EGR rates [12].

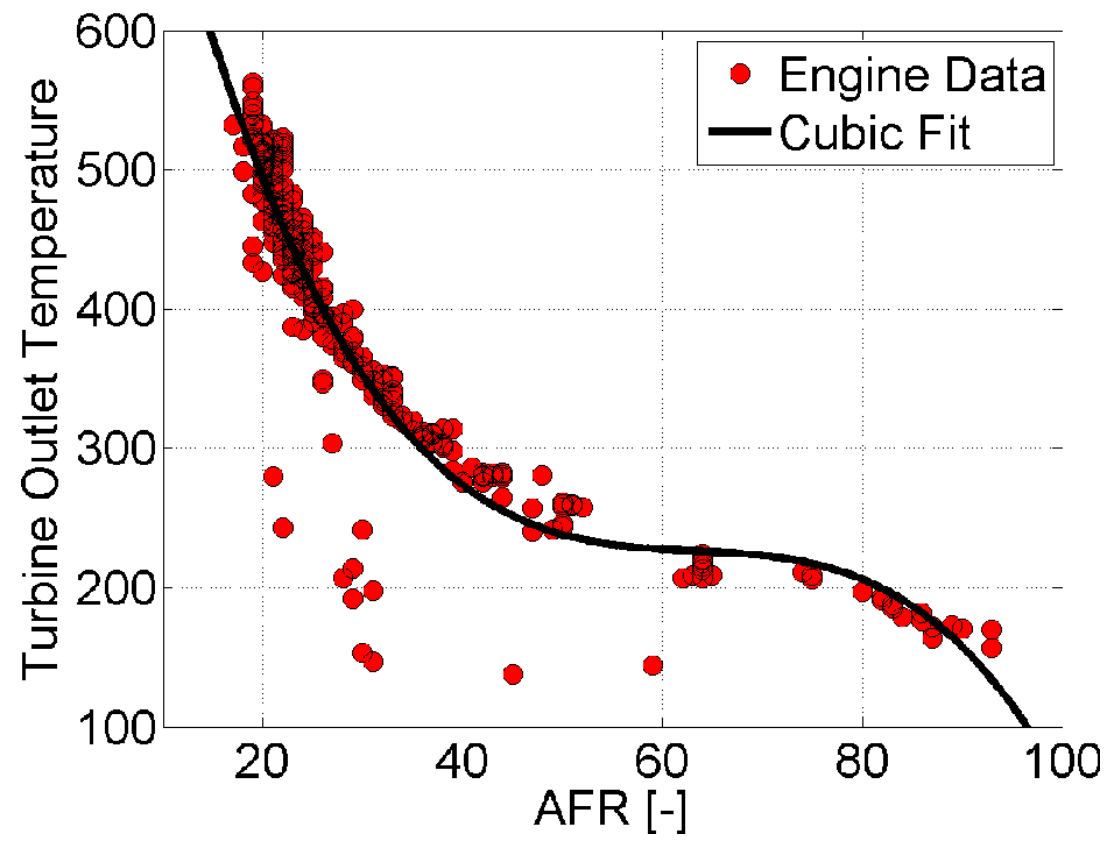

Figure 1.2 Engine Turbo Outlet Temperature vs. AFR [11].

Another objective of the EPAs Cleaner Trucks Initiative and CARB is to "ensure in-use emissions reductions $[4,12]$." One of the ways to do this is to properly determine the useful life of ATS components. This will ensure the compliance with regulations once the ATS is exposed to real world conditions. Current ATS aging procedures for certification 
are not reflective of actual real-life deterioration factors [3]. Aging methods are extremely important to developing ATS components that will be required to perform throughout the useful life of the product. Properly aging the ATS with the correct deterioration factors will allow for more accurate ATS useful life estimates and service dates. Chemical poisoning is the primary cause for catalyst malfunction. This is usually caused by fuel contaminants that could be avoided through improved fuels and processes. Understanding all of the aging effects on the ATS is vital to achieving the goal of technology with a useful life of up to 1 million miles $[3,4]$.

CARB has proposed a program called Real Emissions Assessment Logging or REAL. REAL aims to utilize onboard data loggers to monitor compliance and enforce emissions regulations. They are investigating the feasibility of using NOx sensors to monitor and determine emissions compliance. NOx sensor data could be logged for future inspection or monitored in "real" time to detect emissions compliance issues [3].

The reduction of NOx and PM emissions, ensuring the reduction of emissions through real-time monitoring, and advanced testing capabilities that are reflective of actual "realworld" situations are the overall goals of the EPA and CARB $[3,4]$.

\subsection{Goals and Objectives}

The goal of this research is to acquire experimental data on the $\mathrm{dCSC} \mathrm{CM}^{\mathrm{TM}}$ device, characterize the device's performance, and calibrate a high-fidelity 2D flow through model. This model would aid in the development of the ULN ATS and the overall goals the EPA and CARB. To achieve these goals, an engine test cell and test procedure had to be developed as well as a statistical test matrix. Determining the correct test cell instrumentation to acquire the data for the model was also needed. The specific objectives developed to achieve the research goals are as follows: 
1. Perform a literature study on the $\mathrm{dCSC}^{\mathrm{TM}}$, and other PNAs, related to experimental studies, in order to develop a set of objectives to achieve from the $\mathrm{dCSC}^{\mathrm{TM}}$ experimental data.

2. Determine the experimental data needed in order to calibrate the high-fidelity $2 \mathrm{D}$ flow through model to simulate the Johnson Matthey Cold Start Concept $\left(\mathrm{dCSC}{ }^{\mathrm{TM}}\right)$.

3. Develop the engine test cell setup to perform experimental research on the $\mathrm{dCSC}$.

4. Develop experimental testing procedures and a statistical test matrix.

5. Quantify the $\mathrm{NO}, \mathrm{NO}_{2}$, and $\mathrm{NOx}$ storage performance of the $\mathrm{dCSC} \mathrm{CM}^{\mathrm{TM}}$ at temperatures from $80^{\circ} \mathrm{C}$ to $250^{\circ} \mathrm{C}$ during the cold start period and NOx release performance at temperatures from $200^{\circ} \mathrm{C}$ to $450^{\circ} \mathrm{C}$.

6. Quantify the portion of the stored $\mathrm{NO}, \mathrm{NO}_{2}$, and $\mathrm{NOx}$ that is converted and the portion that remains stored during the warm-up period.

7. Quantify the oxidation characteristics of the $\mathrm{dCSC}^{\mathrm{TM}}$ during the experimental testing.

\subsection{Thesis Outline}

This chapter gives background on the motivation for the research herein. The National Ambient Air Quality Standards (NAAQS) drive the CARB/EPA vehicle and engine emission standards for medium and heavy-duty diesel emissions. These standards drive research to be conducted and options to be explored. This research was to better understand the $\mathrm{dCSC}^{\mathrm{TM}}$ performance during storage and release experiments.

Chapter 2 is a literature review on the $\mathrm{dCSC}^{\mathrm{TM}}$, related experimental studies, and similar technologies. These technologies are all directed towards meeting future Ultra-Low NOx standards.

Chapter 3 is an overview of the test cell setup: engine, dynamometer, instrumentation, emissions analyzers, and the methodology used to process the data. Also described is the 
experimental test procedure developed to achieve the research goals, as well as the experimental test matrix. A test procedure was developed for varying engine conditions, steady-state $\mathrm{dCSC}{ }^{\mathrm{TM}}$ temperatures, and temperature ramp rates.

Chapter 4 covers the results and the Summary/Conclusions from the experimental data. A more extensive description of the instrumentation and the data analysis calculations, time plots, control plots, and other data acquired can be found in Appendices A-H. 


\section{Literature Review}

\subsection{Ultra-Low NOx Aftertreatment Systems}

EPA and CARB are planning to reduce NOx from medium and heavy-duty diesel engines in model years 2024 and 2027 [3, 4]. The ULN standard for 2027 has not been set, but could potentially be a $90 \%$ reduction from the current 0.2 to $0.02 \mathrm{gNOx} / \mathrm{bhp}-\mathrm{hr}$ on the FTP cycle. A study performed by SwRI achieved $0.034 \mathrm{gNOx} / \mathrm{bhp}-\mathrm{hr}$ over the FTP cycle on a 2014 MY 13.0L Volvo diesel engine [3]. Engine hardware changes to aide ATS thermal management and strategic control of ATS thermal management would improve the results of the reference [5]. Figure 2.1 shows the ULN ATS used on the engine at SwRI to achieve the $0.034 \mathrm{gNOx} / \mathrm{bhp}-\mathrm{hr}$ on the FTP cycle. The system features a PNA at the outlet of the engine exhaust.

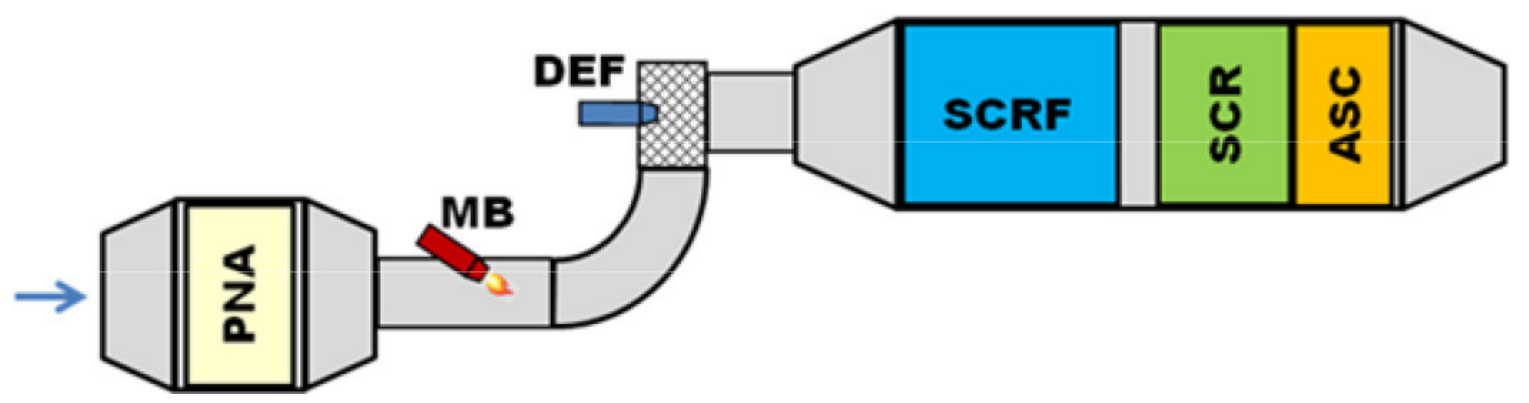

Figure 2.1 ULN ATS used on a Volvo MY 13.0L Diesel Engine at SwRI [5]

The PNA in Figure 2.1 is followed by a diesel fueled mini-burner, DEF injector, SCR-F, $\mathrm{SCR}$, and an ammonia slip catalyst (ASC). The diesel-fueled mini-burner was used as supplemental heat to achieve an SCR-F inlet temperature of $250-350^{\circ} \mathrm{C}$ [13]. The ASC compensates for slip of $\mathrm{NH}_{3}$ from the $\mathrm{SCR}$, leading to $\mathrm{NH}_{3}$ emissions at the tailpipe. The ASC oxidizes $\mathrm{NH}_{3}$ slip from the $\mathrm{SCR}$ into $\mathrm{N}_{2}$ [14]. The PNA adsorbs $\mathrm{NOx}, \mathrm{CO}$, and $\mathrm{HC}$ at low temperatures while the diesel-fueled mini-burner heats the rest of the ATS to its operating temperature $\left(250-350^{\circ} \mathrm{C}\right)$ [13]. Once the SCR is at its operating temperature, it can reduce the NOx in the exhaust gas [15]. The ability of the PNA to store emissions is finite. Therefore, the mini-burner must heat the SCR to its operating temperature (250- 
$350^{\circ} \mathrm{C}$ ) before the PNA reaches its storage capacity. Instead of needing a separate DOC, the PNA serves as the DOC for the system as well. The PNA replaces the DOC with no added thermal mass to the ATS. This is the general architecture of the ULN ATS used at SwRI to conduct the ULN feasibility study on behalf of CARB and the EPA [5].

Another ULN ATS architecture being evaluated, shown in Figure 1.1, is to have a closecoupled SCR (ccSCR) or a LO-SCR in front of the PNA in Figure 2.1. Positioning this SCR in front of all of the other ATS components and as close to the engine as possible will allow it to heat up quickly. It would not reduce NOx at its highest efficiency, but the amount of NOx it does reduce would reduce the workload of the PNA to store NOx during cold start. The LO-SCR would also supplement the ATS during hard acceleration events where a spike in tailpipe NOx emissions is possible [16]. Multiple SCR's within the system would require complex dosing system with the ability to dose at low temperatures. Therefore, the dosing system must be externally heated so that it can effectively deliver DEF to the ATS [16].

Cold start is not the only operation in which NOx emissions must be reduced. The development of the Low Load Cycle (LLC) will test the ULN ATS systems efficiency during low speed and load medium and heavy-duty diesel engine operation. Therefore, it is important that the ATS reaches operating temperature quickly, but also stays at operating temperature (above $200^{\circ} \mathrm{C}$ ). This will be achieved through properly packaging, positioning, and insulating the ATS to reduce thermal losses [16].

\subsection{PNA Fundamentals}

NOx storage or adsorption is a viable strategy for controlling cold start NOx emissions by using PNA technology that can adsorb NOx emissions at temperatures below $200^{\circ} \mathrm{C}$. Common PNA formulations include ceria/alumina-supported $\mathrm{Pd} / \mathrm{Pt}$ and zeolite supported Pd. Ceria/alumina-supported and zeolite supported Pd allows the PNA to store NOx at temperatures below $200^{\circ} \mathrm{C}$ as opposed to the alkaline earth oxide that is used on Lean NOx Trap's. Zeolite supported Pd formulations have superior resistance to sulfur and HC 
poisoning over the ceria/alumina and alkaline earth oxide $\mathrm{Pd} / \mathrm{Pt}$ [17]. In addition to adsorption of NOx the Pd zeolite's serve as an HC trap as well. The combination of an HC trap and NOx adsorber, and good resistance to Sulphur and HC poisoning, makes the zeolite Pd PNA catalyst the best current option for cold start emissions control $[1,8,17$, $18]$.

Figure 2.2 illustrates NO adsorption on a PNA catalyst, from a flow reactor study at the University of Houston [19]. The gas mixture to the reactor was $80{ }^{\circ} \mathrm{C}$ and contained 400 ppm NO, 2\% $\mathrm{O}_{2}$, balance Ar. The gas mixture was comprised of all $\mathrm{NO}$ and no $\mathrm{NO}_{2}$ because diesel engine outlet NOx is $90-95 \%$ NO. The catalyst was fed with the gas for 5 minutes and the downstream $\mathrm{NO}, \mathrm{NO}_{2}$, and $\mathrm{NOx}$ concentrations were measured. There is $400 \mathrm{ppm} \mathrm{NO}$ at the catalyst inlet, therefore a measurement less than $400 \mathrm{ppm}$ of total NOx at the catalyst outlet indicates NO storage or adsorption. The $\mathrm{x}$-axis shows test time in seconds and the y-axis shows downstream PNA $\mathrm{NO}, \mathrm{NO}_{2}$, and $\mathrm{NOx}$ concentrations in ppm. The downstream PNA NOx concentrations are much lower than $400 \mathrm{ppm}$ during the first 100 seconds. Indicating during the first 100 seconds, a large amount of NO is being adsorbed. During the 100 to 300 second time, the downstream PNA NO and NOx concentrations are over $350 \mathrm{ppm}$ which is less than $50 \mathrm{ppm}$ lower than the $400 \mathrm{ppm}$ at the PNA inlet. During these 200 seconds the PNA reaches its NOx adsorption/storage capacity. There is a constant 0 ppm $\mathrm{NO}_{2}$ concentration at the PNA outlet for the duration of the adsorption process that is occurring. The inlet gas temperature, $80^{\circ} \mathrm{C}$, is too low for the PNA to oxidize $\mathrm{NO}$ to $\mathrm{NO}_{2}$. Therefore, $0 \%$ of the upstream $\mathrm{NO}$ is oxidized to $\mathrm{NO}_{2}$ [19]. 


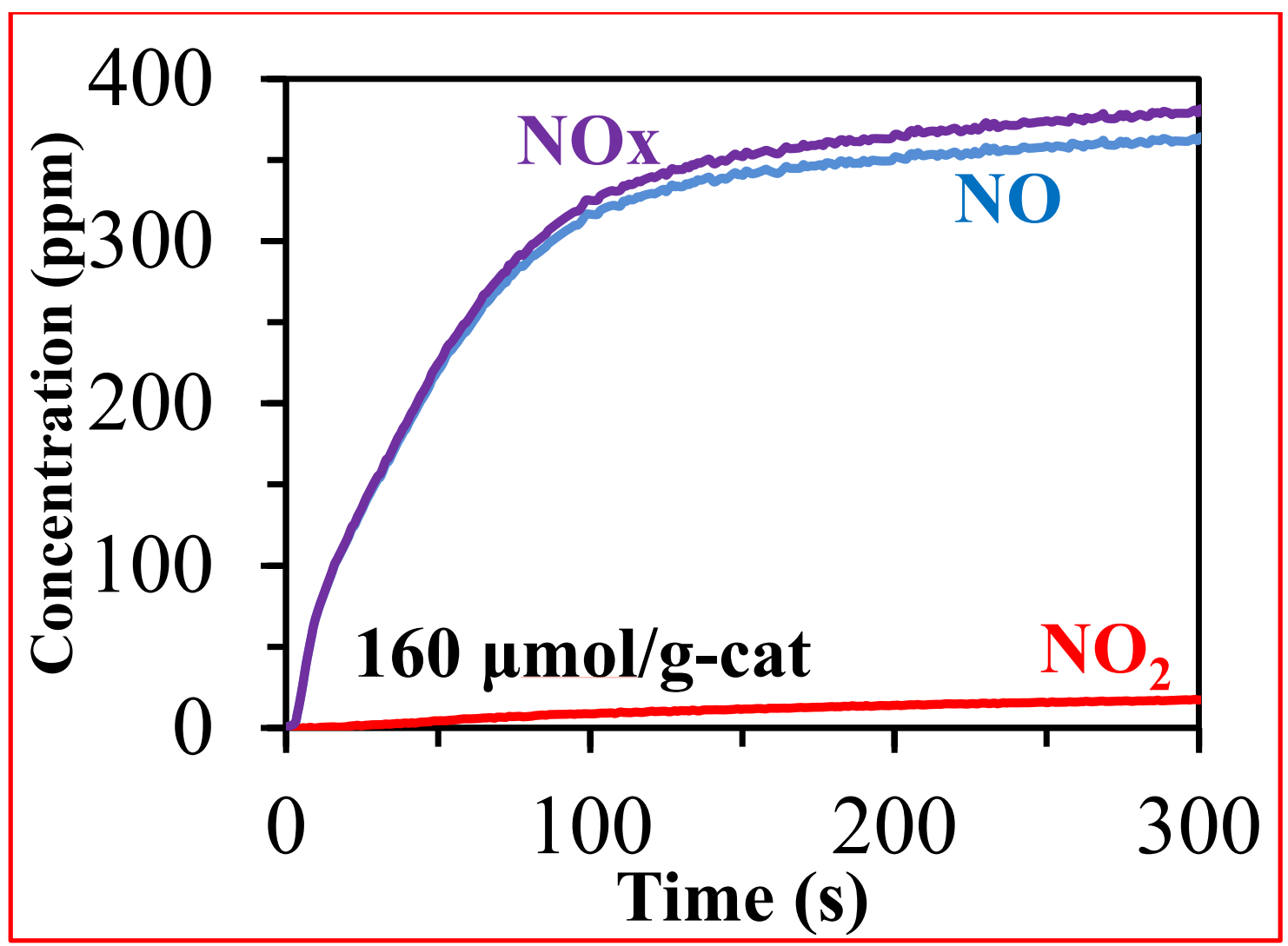

Figure 2.2 NO Adsorption Profile [19]

A NOx desorption profile from the same study, is shown in Figure 2.3. The x-axis shows feed gas temperature in ${ }^{\circ} \mathrm{C}$ and the y-axis shows downstream PNA NO, $\mathrm{NO}_{2}$, and $\mathrm{NOx}$ concentrations in ppm. The y-axis starts at $0 \mathrm{ppm}$, to properly compare the $\mathrm{NO}, \mathrm{NO}_{2}$, and NOx desorption profiles. In Figure 2.3 the PNA is being fed with the same feed gas as Figure 2.2 except for the $400 \mathrm{ppm}$ NO. In this figure, the PNA has reached its NOx peak storage capacity at $80^{\circ} \mathrm{C}$ from the adsorption event in Figure 2.2. The temperature of the feed gas is increasing at a rate of $20^{\circ} \mathrm{C}$ per minute from 80 to $500{ }^{\circ} \mathrm{C}$. As the feed gas temperature increases, the downstream PNA NO, $\mathrm{NO}_{2}$, and $\mathrm{NOx}$ concentrations increase. The PNA inlet NO concentration is not increasing and the outlet concentration is increasing indicating NOx is being desorbed from the PNA. The downstream PNA NOx concentration reaches a peak as the feed gas temperature reaches $150{ }^{\circ} \mathrm{C}$. The PNA continues to release NOx until the feed gas temperature reaches $250^{\circ} \mathrm{C}$. The presence of $\mathrm{NO}_{2}$ downstream of the PNA indicates the PNA is oxidizing $\mathrm{NO}$ to $\mathrm{NO}_{2}$. The $\mathrm{d}_{200}=52 \%$ 
in the top right corner of Figure 2.3 indicates that by the time the feed gas temperature reached $200{ }^{\circ} \mathrm{C}, 52 \%$ of the adsorbed NOx had been desorbed.

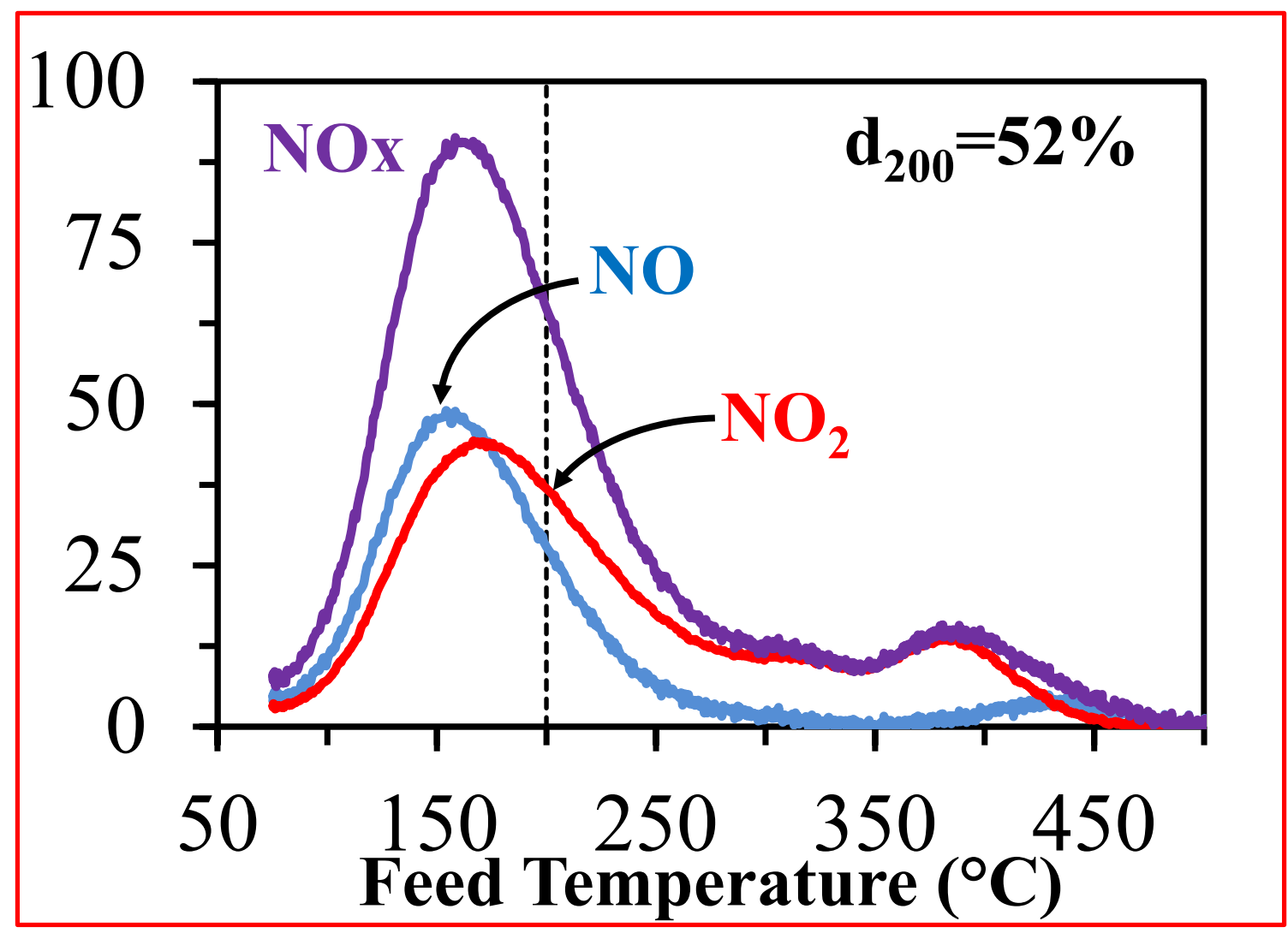

Figure 2.3 NOx Desorption Profile [19]

Similar profiles are observed for the storage and release of other exhaust gas constituents: such as $\mathrm{CO}$ and $\mathrm{HC}$. The presence of $\mathrm{H}_{2} \mathrm{O}$ in the exhaust gas can inhibit the ability of the PNA to adsorb $\mathrm{HC}$ and NOx. The presence of $\mathrm{CO}$ in exhaust gas can mitigate this inhibition [20].

The same experiment as Figure 2.2 was conducted three times in Figure 2.4. Of those three experiments, two were conducted with the addition of $5 \% \mathrm{H}_{2} \mathrm{O}$ in the feed gas and one was conducted with no $\mathrm{H}_{2} \mathrm{O}$ in the feed gas. Of those two experiments containing 5\% $\mathrm{H}_{2} \mathrm{O}$ in the feed gas, one was "oxytreated" beforehand. The "oxytreatment" consists of a $10 \% \mathrm{O}_{2}$ balance Ar feed gas to the reactor at $750^{\circ} \mathrm{C}$ for two hours. The data in Figure 2.4 
illustrates the inhibition of water on NOx adsorption by comparing the PNA NOx adsorption profiles from the three experiments [19].

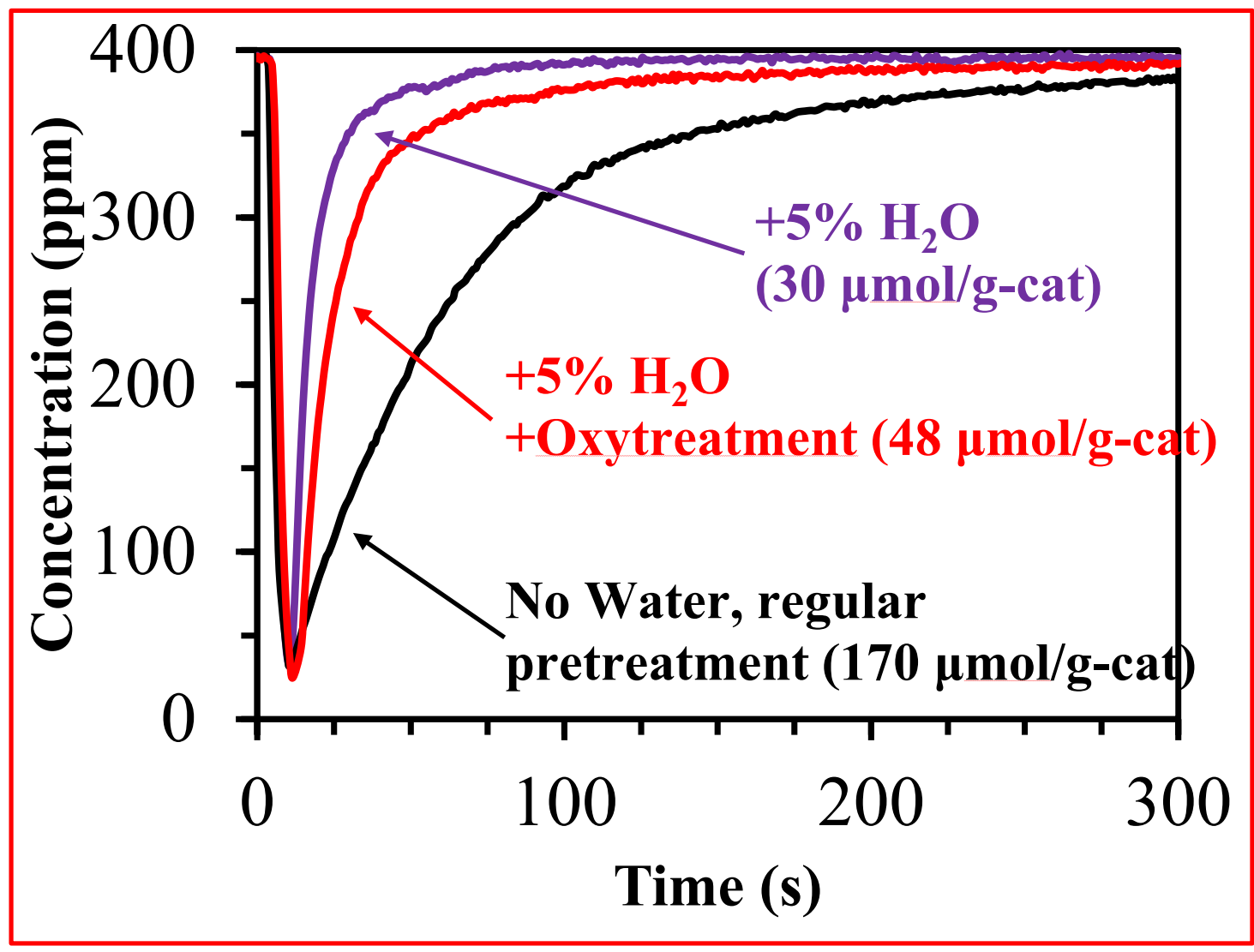

Figure 2.4 $\mathrm{H}_{2} \mathrm{O}$ Effects on NOx Storage Capacity [19]

The y-axis shows NOx concentration in ppm and the $\mathrm{x}$-axis shows time, in seconds. The addition of water in the exhaust will inhibit the PNA's ability to store NOx. Therefore, higher NOx concentrations will be observed sooner at the PNA outlet with increasing $\mathrm{H}_{2} \mathrm{O}$ concentrations. The oxytreatment attempts to reduce this water inhibition. At the 50 second time, the $\mathrm{NO}$ concentration downstream of the PNA with no $\mathrm{H}_{2} \mathrm{O}$ in the feed gas and no oxytreatment was $200 \mathrm{ppm}$. The NO concentration downstream of the PNA that was fed with feed gas containing $5 \% \mathrm{H}_{2} \mathrm{O}$ and no oxytreatment was $375 \mathrm{ppm}$ at the 50 second time. The NO concentration downstream of the PNA that was oxytreated and fed with feed gas containing $\mathrm{H}_{2} \mathrm{O}$ was $345 \mathrm{ppm}$. Therefore, the "oxytreated" experiment, containing $5 \% \mathrm{H}_{2} \mathrm{O}$ in the feed gas, experienced less NOx storage inhibition than the 
experiment containing the $5 \% \mathrm{H}_{2} \mathrm{O}$ without oxytreatment. Therefore, it can be deduced that the oxytreatment reduced the inhibition effect of $\mathrm{H}_{2} \mathrm{O}$ in the feed gas. In both the oxytreated and non oxytreated case, the $5 \% \mathrm{H}_{2} \mathrm{O}$ present in the feed gas caused the downstream PNA NO concentration to increase more rapidly than the experiment with no $\mathrm{H}_{2} \mathrm{O}$.

\subsection{PNA, DOC, and Cold Start Concept Catalyst Performance}

The Johnson Matthey Diesel Cold Start Concept (dCSC ${ }^{\mathrm{TM}}$ ), is a PNA with HC trapping ability on an oxidation catalyst $[1,8]$. In reference [1], the dCSC ${ }^{\text {TM }}$ was compared to a separate DOC and PNA to show the advantages of the $\mathrm{dCSC}^{\mathrm{TM}}$ which has coupling of DOC and PNA technologies [1].

The dCSC ${ }^{\mathrm{TM}}$, DOC, and PNA were exposed to $5 \% \mathrm{H}_{2} \mathrm{O}$, balance air, at $750{ }^{\circ} \mathrm{C}$, for 16 hours. The substrates were then fed gas containing $10 \% \mathrm{O}_{2}, 5 \% \mathrm{CO}_{2}, 5 \% \mathrm{H}_{2} \mathrm{O}$, balance $\mathrm{N}_{2}$ at $650^{\circ} \mathrm{C}$ to clean the substrates of any stored emissions. All three substrates were then cooled to a temperature of $80^{\circ} \mathrm{C}$ with the same feed gas composition. Once the substrates reached a steady state temperature of $80^{\circ} \mathrm{C}, 200 \mathrm{ppm} \mathrm{NO}, 200 \mathrm{ppm} \mathrm{CO}$, and $500 \mathrm{ppm}$ decane (on a $\mathrm{C}_{1}$ basis) was added to the feed gas for 100 seconds. At the conclusion of the 100 seconds, the temperature of the feed gas was increased from 80 to $650^{\circ} \mathrm{C}$ at a rate of $100{ }^{\circ} \mathrm{C}$ per minute [1].

During this experiment, $\mathrm{CO}$ concentrations were measured downstream of the $\mathrm{dCSC} \mathrm{CM}^{\mathrm{TM}}$, PNA, and DOC. Figure 2.5 shows the CO oxidation comparison between the $\mathrm{dCSC} \mathrm{CM}^{\mathrm{TM}}$, DOC, and PNA. The dCSC ${ }^{\mathrm{TM}}$ is referred to in the plot legend as the CSC. At the 50 second point in the experiment, the downstream $\mathrm{dCSC}^{\mathrm{TM}}$ and PNA CO concentrations are around $50 \mathrm{ppm}$ and the downstream DOC CO concentration is around $175 \mathrm{ppm}$. The amount of PGM on each substrate effects the $\mathrm{CO}$ oxidation capabilities of each substrate [1]. The PNA and dCSC ${ }^{\text {TM }}$ contain a significantly higher amount of PGM than the DOC substrate. This is why the $\mathrm{CO}$ oxidation of the PNA and $\mathrm{dCSC} \mathrm{CM}^{\mathrm{TM}}$ is greater than the DOC. 
100 seconds into the experiment, the feed gas starts its temperature ramp from 80 to 650 ${ }^{\circ} \mathrm{C}$. As soon as the feed gas temperature starts increasing, the downstream PNA and dCSC $^{\text {TM }} \mathrm{CO}$ concentrations start decreasing. Both downstream PNA and dCSC ${ }^{\text {TM }} \mathrm{CO}$ concentrations reach $0 \mathrm{ppm}$ before the feed gas temperature reaches $140{ }^{\circ} \mathrm{C}$. The downstream DOC CO concentration does not start decreasing until the feed gas temperature reaches $140{ }^{\circ} \mathrm{C}$ and reaches $0 \mathrm{ppm}$ once the feed gas temperature reaches 200 ${ }^{\circ} \mathrm{C}[1]$.

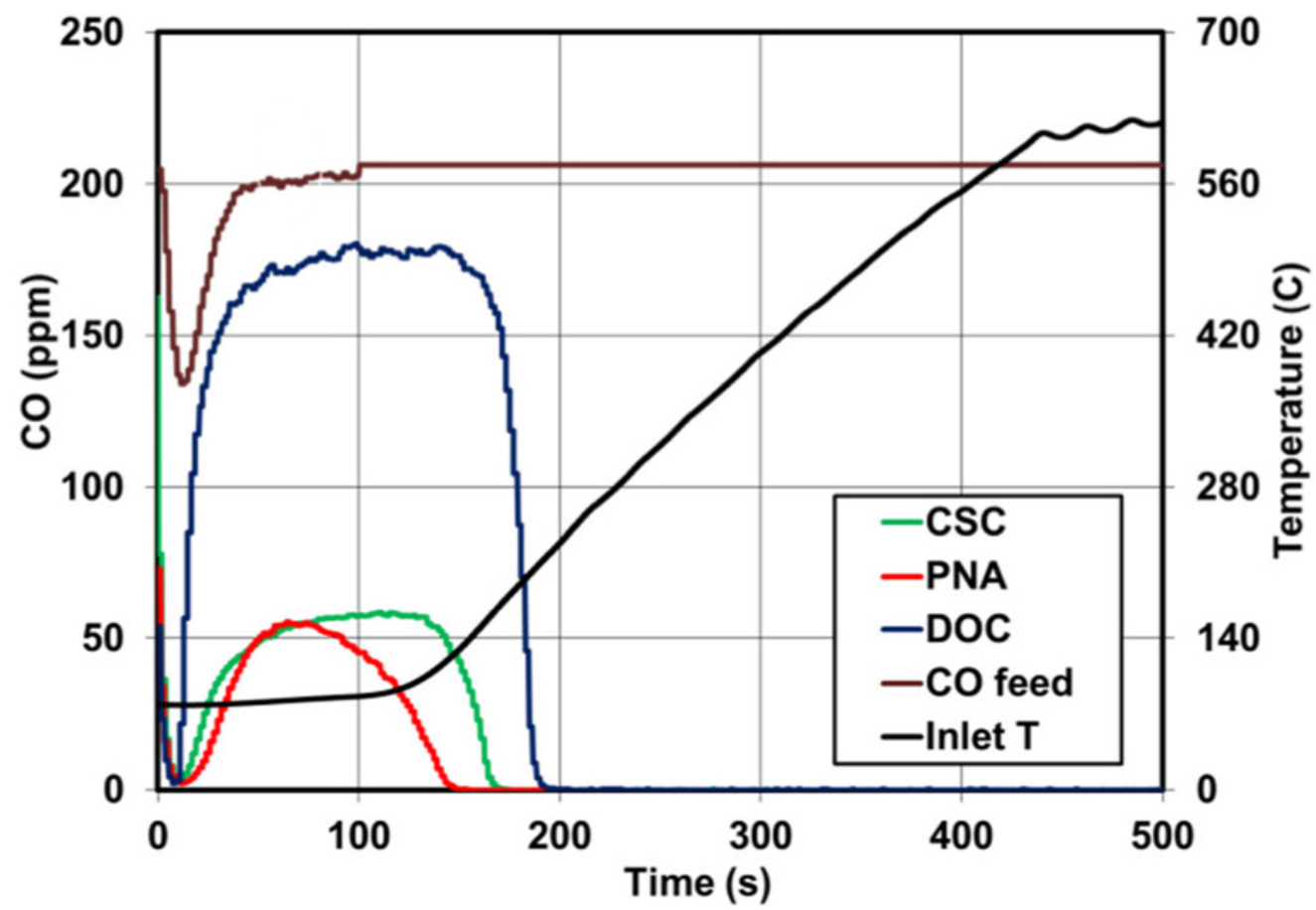

Figure 2.5 Downstream DOC, PNA, and dCSC ${ }^{\text {TM }}$ CO Concentrations vs. Time and Temperature [1]

The dCSCTM and PNA show significantly higher CO oxidation than the DOC [1]. During the same experiment as Figure 2.5, downstream dCSC ${ }^{\mathrm{TM}}$, DOC, and PNA HC concentrations were measured. Figure 2.6 shows the HC concentrations downstream of the substrates. From time 0 to 100 seconds, the downstream HC concentrations of all three substrates are less than $50 \mathrm{ppmC}$ (on $\mathrm{C}_{1}$ basis), while the upstream $\mathrm{HC}$ concentration is $500 \mathrm{ppmC}$. Therefore, all three substrates show significant HC adsorption per reference [1]. 
At the 100 second point, the inlet gas temperature starts increasing from 80 to $650{ }^{\circ} \mathrm{C}$. When the inlet gas temperature reaches $150^{\circ} \mathrm{C}$, the downstream DOC and PNA HC concentrations begin to increase indicating desorption of HC. The downstream dCSC TM $\mathrm{HC}$ concentration does not start increasing until the inlet gas temperature reaches $200{ }^{\circ} \mathrm{C}$. At $220{ }^{\circ} \mathrm{C}$ inlet gas temperature of all three downstream substrate temperatures peak. The downstream PNA concentration peaks highest at $120 \mathrm{ppmC}$, the downstream DOC HC concentration peaks at $100 \mathrm{ppmC}$, and the downstream $\mathrm{dCSC} \mathrm{CM}^{\mathrm{TM}} \mathrm{HC}$ concentration peaks at slightly over 50 ppmC. The peak downstream dCSC ${ }^{\text {TM }} \mathrm{HC}$ concentration is less than half of the peak downstream DOC and PNA HC concentrations. This shows that the $\mathrm{dCSC}^{\mathrm{TM}}$ more effectively converts the stored HC than the DOC and PNA substrates. Once the inlet gas temperature reaches above $250{ }^{\circ} \mathrm{C}$, all three substrates show $100 \% \mathrm{HC}$ oxidation efficiency [1].

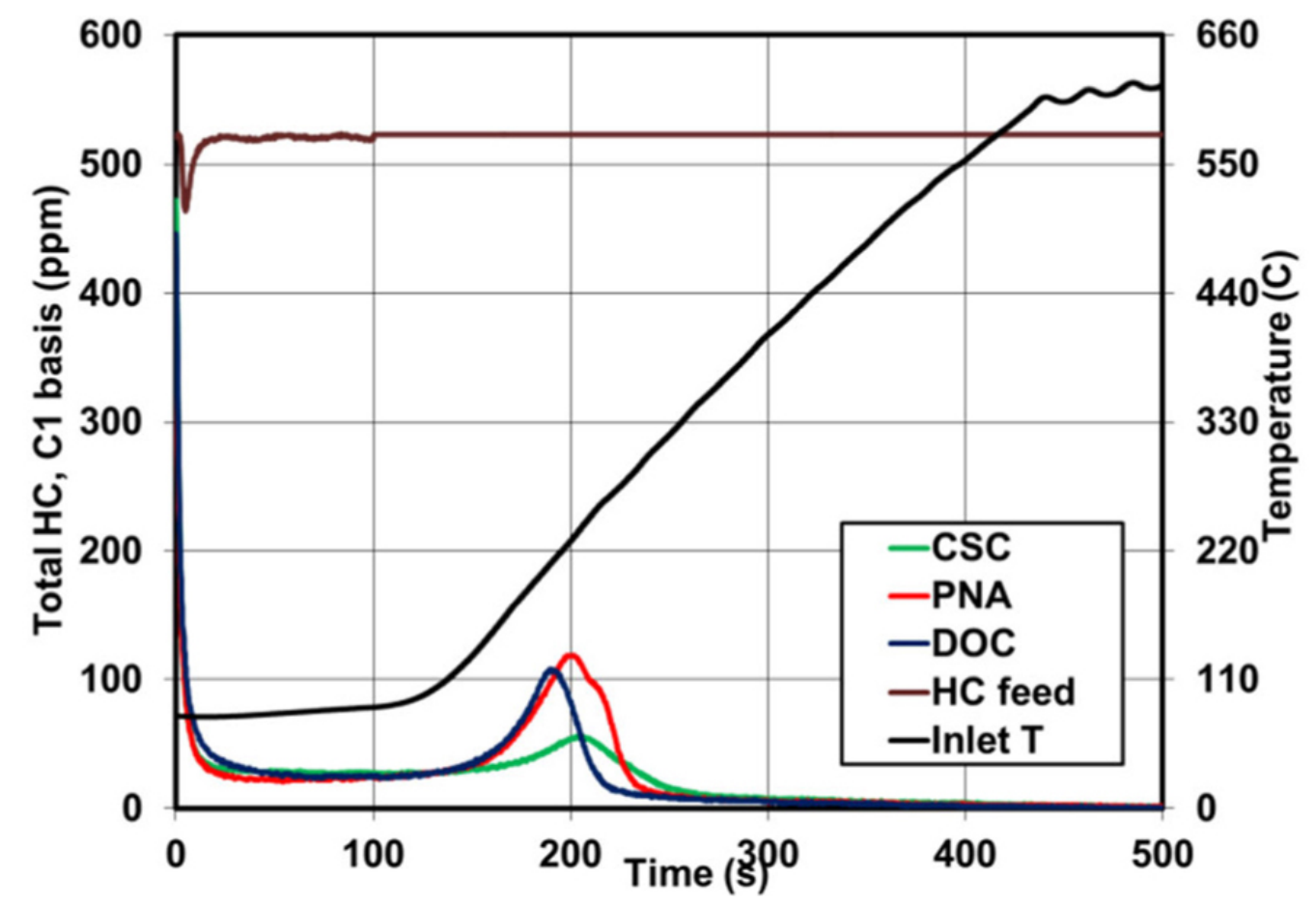

Figure 2.6 Downstream DOC, PNA, and dCSC ${ }^{\text {TM }}$ HC Concentrations vs. Time and Temperature [1]

It was determined during further testing in reference [8] that during the temperature ramp in Figures 2.5 and 2.6 that $\mathrm{N}_{2} \mathrm{O}$ is produced due to the $\mathrm{HC}$ lean NOx reductions 
occurring. Peak downstream substrate $\mathrm{N}_{2} \mathrm{O}$ concentrations observed were 126,74 , and 30 ppm for the DOC, PNA, and dCSC ${ }^{\text {TM }}$ substrates, respectively [8].

An additional experiment was run in reference [1] to characterize steady state $\mathrm{NO}$ to $\mathrm{NO}_{2}$ oxidation activity of the DOC and dCSCTM. Figure 2.7 shows the steady state $\mathrm{NO}_{2} / \mathrm{NOx}$ ratio downstream of the $\mathrm{DOC}$ and $\mathrm{dCSC}^{\mathrm{TM}}$ substrates vs. temperature. The same feed gas containing 200 ppm NO, 200 ppm CO, 500 ppmC decane ( $\mathrm{C}_{1}$ basis), $10 \% \mathrm{O}_{2}, 5 \% \mathrm{CO}_{2}$, $5 \% \mathrm{H}_{2} \mathrm{O}$, balance $\mathrm{N}_{2}$ was fed to the DOC and dCSCTM at temperatures from 200 to 550 ${ }^{\circ} \mathrm{C}$, in $50{ }^{\circ} \mathrm{C}$ intervals. The gases were fed to the DOC and $\mathrm{dCSC}{ }^{\mathrm{TM}}$ substrates for 30 minutes to ensure steady state $\mathrm{NO}$ to $\mathrm{NO}_{2}$ oxidation was occurring [1].

The dCSC ${ }^{\mathrm{TM}}$ substrate shows slightly less $\mathrm{NO}$ to $\mathrm{NO}_{2}$ oxidation than the DOC. Both the $\mathrm{dCSC}^{\mathrm{TM}}$ and $\mathrm{DOC}$ have peak $\mathrm{NO}_{2} / \mathrm{NOx}$ oxidation performance at a substrate temperature of $300^{\circ} \mathrm{C}$. At $300{ }^{\circ} \mathrm{C}$ the $\mathrm{dCSC} \mathrm{CM}^{\mathrm{TM}}$ converts $45 \%$ of the upstream $\mathrm{NO}$ to $\mathrm{NO}_{2}$ and the DOC converts $55 \%$. The $\mathrm{NO}$ oxidation of both is substantial from $250^{\circ} \mathrm{C}$ to $350^{\circ} \mathrm{C}$. At substrate temperatures lower than $250^{\circ} \mathrm{C}$ and higher than $350^{\circ} \mathrm{C}$ the $\mathrm{NO}$ oxidation decreases significantly [1].

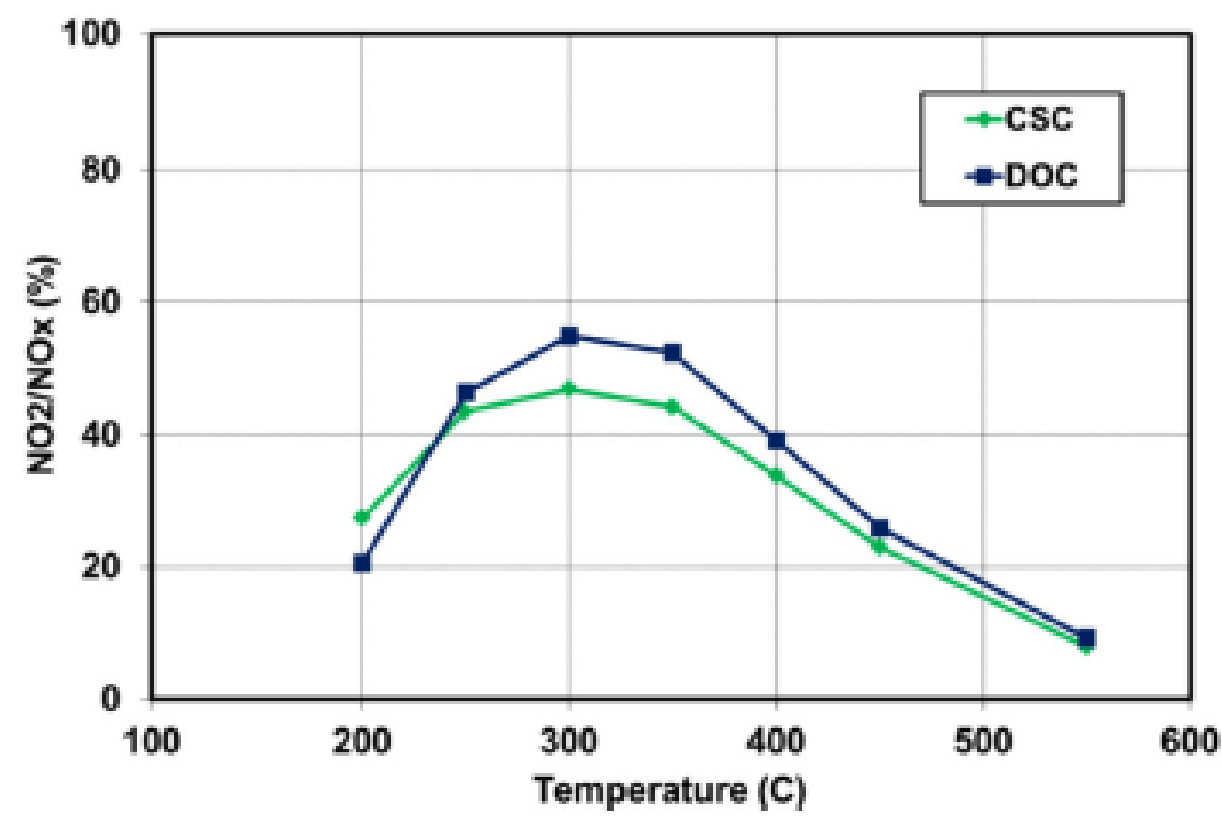

Figure 2.7 Downstream dCSC ${ }^{\mathrm{TM}}$ and $\mathrm{DOC} \mathrm{NO}_{2} / \mathrm{NOx}$ Ratio vs. Temperature [1]. 
Figure 2.8 shows the 200 -second NOx storage capacity of the Johnson Matthey Diesel Cold Start Concept (dCSCTM) [8]. In addition to the experiments above, experiments were performed in reference [8] to quantify the NOx storage capability of the dCSCTM. In reference [8], multiple cold start concept substrates containing PNA catalyst with HC trapping ability and an oxidation catalyst were prepared. All of the experiments took place in a laboratory reactor. First, the substrates were hydrothermally aged at $650{ }^{\circ} \mathrm{C}$ for 2 hours with various feed gas compositions to reflect different air-to-fuel ratios.

NOx adsorption experiments were performed with feed gas mixtures comprised to emulate exhaust gas from a diesel engine during cold start. The substrates were preheated to $500{ }^{\circ} \mathrm{C}$ in feed gas of $10 \% \mathrm{O}_{2}, 5 \% \mathrm{CO}_{2}, 5 \% \mathrm{H}_{2} \mathrm{O}$, and a balance of $\mathrm{N}_{2}$. The substrates were held at $500{ }^{\circ} \mathrm{C}$ to ensure desorption of any emissions from all of the active NO storage sites on the catalysts. The substrates were then cooled to low temperatures ranging from 80 to $250^{\circ} \mathrm{C}$ with the same feed gas composition. Once the substrates reached the temperature setpoint for the certain test, $200 \mathrm{ppm} \mathrm{NO}, 200 \mathrm{ppm} \mathrm{CO}$, and 500 ppmC decane (on a $\mathrm{C}_{1}$ basis) was added to the feed gas. The substrates were fed with this gas from 10 minutes to ensure complete saturation of all of the available NOx storage sites [8].

The NOx storage capacity of the substrates at temperatures of 80 to $250^{\circ} \mathrm{C}$ is characterized in Figure 2.8. The optimal temperature of the substrates to store NOx emissions is observed from 125 to $175^{\circ} \mathrm{C}$ where the NOx storage capacity peaks [8]. The storage capacity falls off from 125 to $80{ }^{\circ} \mathrm{C}$. As feed gas temperature decreases from 125 to $80^{\circ} \mathrm{C}, \mathrm{H}_{2} \mathrm{O}$ presence in the feed gas increases, this presence of water inhibits the NO storage sites from storing the NO in the feed gas. Storage capacity also decreases as temperature increases from 200 to $250^{\circ} \mathrm{C}$. This is due to the NO storage sites becoming unstable above $200^{\circ} \mathrm{C}[8]$. 


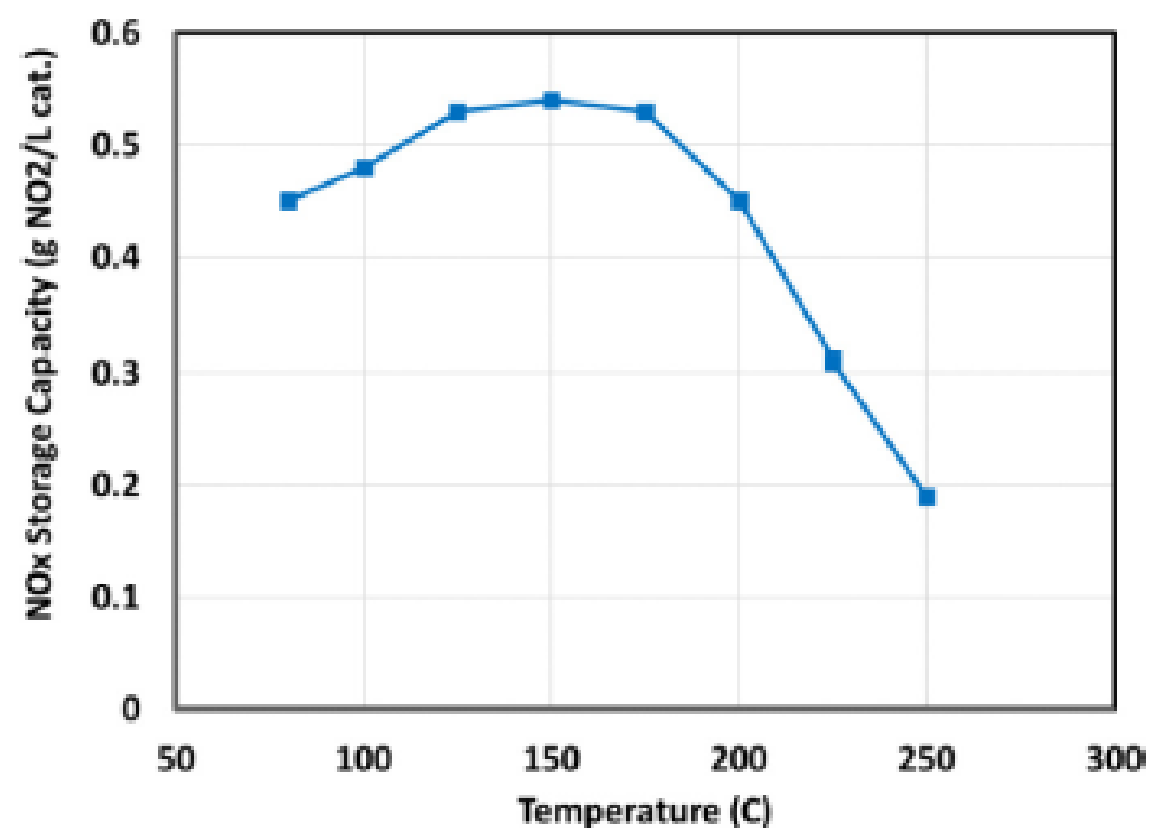

Figure 2.8 200-Second dCSC ${ }^{\text {TM }}$ NOx Storage Capacity vs. Temperature [8]

\subsection{Summary}

The $\mathrm{dCSC}^{\mathrm{TM}}$ device would integrate into the ULN ATS in Figure 2.1 as the PNA.

Followed by an external heat source of some sort, to reduce the time the SCR and the rest of the ATS needs to reach operating temperature $[11,16]$. The goal of the system is to meet ULN regulations for medium and heavy-duty diesel engines for 2024, 2026, and subsequent MY's. The EPA and CARB also plan for regulations over time to include emissions compliance for all use-cases, extended warranty requirements, accurate useful life determinations, and real time emissions logging capabilities [3].

Research has consisted of laboratory reactor studies on various substrates $[1,8,19,16]$, engine dynamometer studies on ULN ATS architectures [5, 13], engine hardware and calibration changes, [5, 16, 12], the development of new test cycles [7], and additional research studies to evaluate the feasibility and methods for achieving regulations laid out in reference [3]. 
The goal of this research is to acquire experimental data on the $\mathrm{dCSC} \mathrm{CM}^{\mathrm{TM}}$ device, characterize the device's performance, and use the data to calibrate a high-fidelity 2D flow through model of the $\mathrm{dCSC}{ }^{\mathrm{TM}}$. The model will be able to accurately predict outlet $\mathrm{dCSC}^{\mathrm{TM}}$ species concentrations, 2D temperature distributions, delta pressure, etc. This may be the first model of the $\mathrm{dCSC}{ }^{\mathrm{TM}}$ and it will be very useful for the development of the ULN ATS, aiding the efforts being made by the EPA, CARB, and companies that need to meet future regulations. 


\section{Experimental Setup and Procedures}

The experimental set-up was developed in order to carry out the experiments to gather the data needed to meet the objectives outlined in the Introduction. The test procedures and the experiments were then designed to get the data needed for the $\mathrm{dCSC} \mathrm{CM}^{\mathrm{TM}}$ model and to determine the effect of the various variables on the storage, release, and oxidation of NO, $\mathrm{NO}_{2}, \mathrm{CO}$, and $\mathrm{N}_{2} \mathrm{O}$. The calculation procedures and equations used for analyzing the experimental data are also explained.

\subsection{Experimental Setup}

This section covers the general test cell layout, engine and dynamometer, fuel properties, exhaust heater, and ATS. The purpose of this section is to give background information on the experimental setup, engine, fuel properties, electric heater capability, and the aftertreatment system components.

\subsubsection{Test Cell Layout}

Figure 3.1 shows the layout of the Michigan Tech diesel engine aftertreatment test cell which was specifically modified to perform the $\mathrm{dCSC}^{\mathrm{TM}}$ research. Additions to the test cell included the Thermo Fisher $46 \mathrm{i} \mathrm{N}_{2} \mathrm{O}$ analyzer, a Cambustion fNOx400 NOx analyzer, and a Cambustion HFR 400 Fast FID total hydrocarbon analyzer. The ambient air inlet and valve B were also added. 


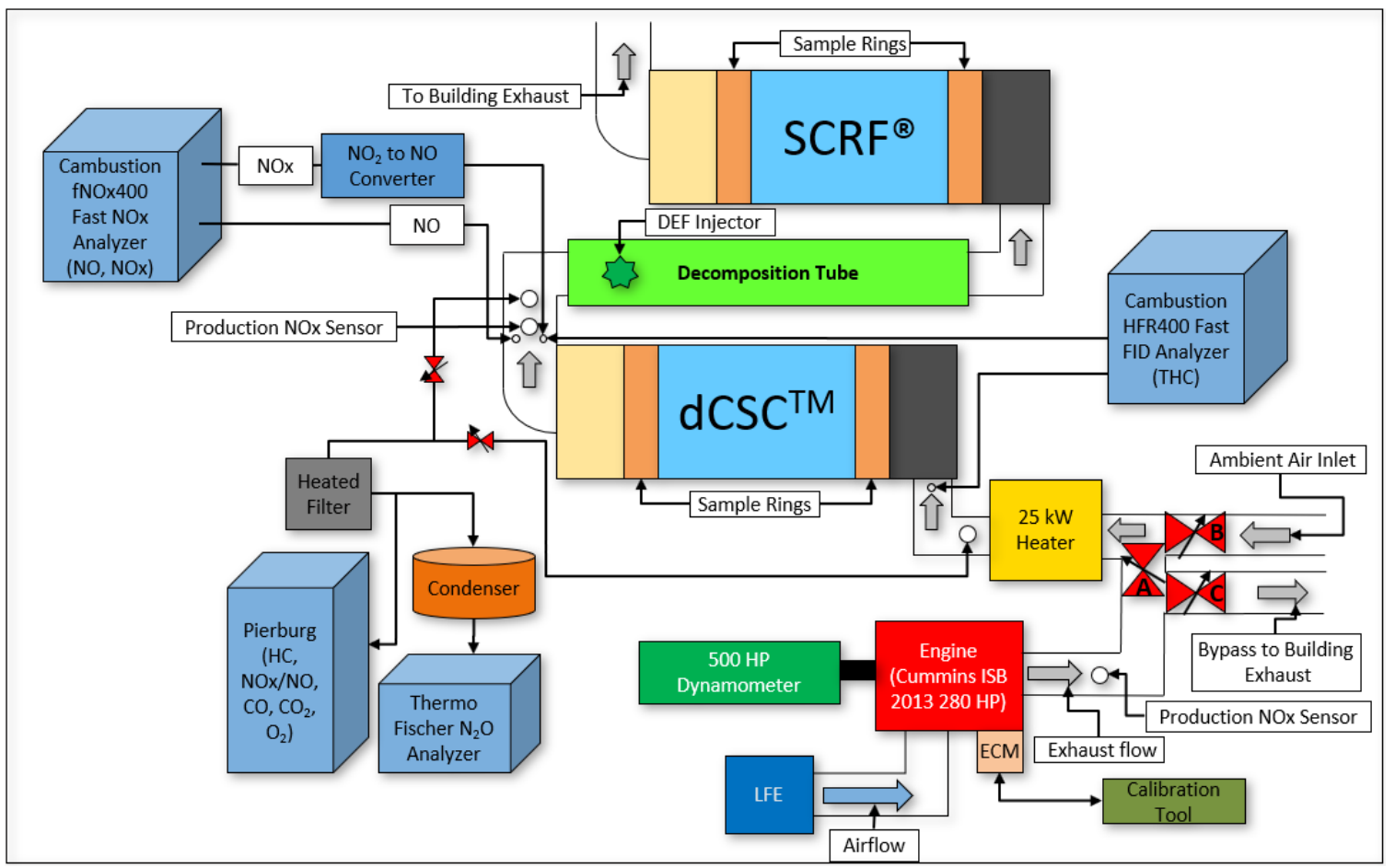

Figure 3.1 Test Cell Layout

The 2013 6.7L 6-cylinder Cummins ISB engine is coupled to a 500 HP dynamometer. The engine is controlled by the Calterm calibration tool provided by Cummins. A laminar flow element accurately measures the mass flow rate of air into the engine. A $25-\mathrm{kW}$ heater from Watlow is in-line to control exhaust temperature to desired setpoints. See Appendix A for additional information on the exhaust heater. There are two NOx sensors in the ATS. One sensor measures the engine outlet NOx concentrations and the other measures downstream dCSC ${ }^{\mathrm{TM}}$ NOx concentrations. See Appendix B for additional information on the NOx sensors. The Pierburg 5-gas analyzer and $\mathrm{N}_{2} \mathrm{O}$ analyzer can measure emissions upstream or downstream of the $\mathrm{dCSC}^{\text {TM }}$. Appendices B. 1 and B. 4 have additional information on the Pierburg 5-gas bench and Thermo Fisher $\mathrm{N}_{2} \mathrm{O}$ analyzer, respectively. Two fast response analyzers from Cambustion are part of the instrumentation. One of the analyzers measures NO and NOx and the other measures HC. For more information on the Cambustion analyzers see Appendices B.2 and B.3. Each Cambustion analyzer has two channels, one upstream and one downstream of the $\mathrm{dCSC}^{\mathrm{TM}}$. There is a DEF injector downstream of the $\mathrm{dCSC}^{\mathrm{TM}}$ and upstream of the 
SCRF®. The SCRF® is a Selective Catalytic Reduction catalyst on a Diesel Particulate Filter (DPF).

\subsubsection{Engine and Dynamometer}

As stated earlier, a 2013 6.7L inline 6-cylinder Cummins ISB engine, rated for $280 \mathrm{HP}$ at $2400 \mathrm{rpm}$, was used to conduct the experimental testing. A list of engine specifications is shown in Table 3.1. The engine is coupled to a Dynamatic water-cooled eddy current dynamometer rated for $500 \mathrm{HP}$ from 1700-7000 rpm. The dyno controls engine speed through a Digalog dynamometer controller.

Table 3.1 Engine Specifications

\begin{tabular}{|l|l|}
\hline Model & Cummins ISB \\
\hline MY & 2013 \\
\hline Displacement & $6.7 \mathrm{~L}, 408$ in $^{3}$ \\
\hline Cylinders & 6 \\
\hline Aspiration & Holset Variable Geometry Turbocharger \\
\hline Bore \& Stroke & $107 \times 124 \mathrm{~mm}$ \\
\hline EGR System & Electronically controlled and cooled \\
\hline CR & $17.3: 1$ \\
\hline Firing Order & $1-5-3-6-2-4$ \\
\hline Fuel System & High pressure common rail, Bosch DI \\
\hline Rated power and speed & $280 \mathrm{HP}$ at $2400 \mathrm{rpm}$ \\
\hline Rated torque and speed & $660 \mathrm{lb}-\mathrm{ft}$ at $1600 \mathrm{rpm}$ \\
\hline
\end{tabular}

\subsubsection{Fuel Properties}

A batch of summer blend \#2 ultra-low sulfur diesel (ULSD \#2) was purchased and stored at Krans Oil in Lake Linden for the $\mathrm{dCSC}^{\mathrm{TM}}$ testing. A fuel sample was sent to Paragon Laboratories in Livonia, Michigan for analysis and the results are shown in Table 3.2. For the complete analysis results from Paragon see Appendix C. 
Table 3.2 ULSD \#2 Fuel Properties used in Engine

\begin{tabular}{|l|l|}
\hline Fuel Type & ULSD $\# 2$ \\
\hline Carbon $(\mathrm{Wt} \%)$ & $86.55 \%$ \\
\hline Hydrogen $(\mathrm{Wt} \%)$ & $13.45 \%$ \\
\hline API Gravity at $15.56^{\circ} \mathrm{C}$ & $34.5^{\circ} \mathrm{API}$ \\
\hline Density at $15.56^{\circ} \mathrm{C}$ & $0.8516 \mathrm{~g} / \mathrm{mL}$ \\
\hline Specific Gravity at $15.56^{\circ} \mathrm{C}$ & 0.8524 \\
\hline LHV & $19669 \mathrm{BTU} / \mathrm{lb} 45.749$ \\
\hline NLHV & $18442 \mathrm{BTU} / \mathrm{lb} 42.895$ \\
\hline Cetane & 51.7 \\
\hline Air to Fuel Ratio (CH-based) & 14.58 \\
\hline Hydrogen to Carbon Atomic Ratio & 1.852 \\
\hline
\end{tabular}

\subsubsection{Exhaust Heater}

A $25-\mathrm{kW}$ heater was used to control exhaust gas temperatures to the desired setpoints for the dCSCTM testing. The heater and the heater controller were manufactured by Watlow. Controller PID's were tuned to eliminate temperature oscillations and they ensure temperature setpoint accuracy. Additional details on the exhaust heater and heater PID tuning are in Appendix A.

\subsubsection{Aftertreatment System}

The ATS consists of a Johnson Matthey dCSC ${ }^{\mathrm{TM}}$ upstream of an SCRF $^{\circledR}$ previously used to conduct research at MTU $[21,22]$. The $\mathrm{dCSC}^{\mathrm{TM}}$ was degreened before the experimental testing began. The $\mathrm{dCSC}^{\mathrm{TM}}$ was degreened by running the engine at 1660 $\mathrm{rpm}, 550 \mathrm{~N}-\mathrm{m}$, and with $32 \mathrm{mg} / \mathrm{stroke}$ of late fuel injection. The $25-\mathrm{kW}$ heater was set to $700^{\circ} \mathrm{C}$ and the $\mathrm{dCSC}^{\mathrm{TM}}$ was held at temperatures between 650 and $700^{\circ} \mathrm{C}$ for 2 hours. This was done to emulate the hydrothermal aging done on the cold start concept technology testing in $[1,8]$. The $\mathrm{dCSC}^{\mathrm{TM}}$ substrate specifications are shown in Table 3.3. 
Table 3.3 dCSC ${ }^{\text {TM }}$ Substrate Specifications

\begin{tabular}{|l|l|}
\hline Material & Cordierite \\
\hline Diameter (inch) & 10.5 \\
\hline Length (inch) & 6 \\
\hline Cell Geometry & Square \\
\hline Total Volume (L) & 8.51 \\
\hline Open Volume (L) & 7.72 \\
\hline Cell Density /in & \\
\hline Cell Width (in) & 400 \\
\hline Open Frontal Area (in $\left.{ }^{2}\right)$ & 0.046 \\
\hline Channel Wall Thickness (in) & 78.5 \\
\hline Wall Density (g/cm $\left.{ }^{3}\right)$ & 0.004 \\
\hline Porosity (\%) & 1.2 \\
\hline Number of Inlet Cells & 35 \\
\hline
\end{tabular}

*Total Volume minus No Flow Zone

\subsection{Instrumentation}

This section introduces the instrumentation used to record the data needed to meet the research objectives. Numerous thermocouples, pressure transducers, emission analyzers, and DAQ systems were utilized to gather the data needed.

\subsubsection{Temperature Measurement}

The $\mathrm{dCSC}{ }^{\mathrm{TM}}$ substrate is instrumented with 32 thermocouples. These thermocouples are 16-inch Omega K-type MQSS series thermocouples with a 304 stainless steel sheath. The temperature data are used to monitor the $2 \mathrm{D}$ temperature distribution during testing.

Figure 3.2 shows the location of each thermocouple in the $\mathrm{dCSC}^{\mathrm{TM}}$. 

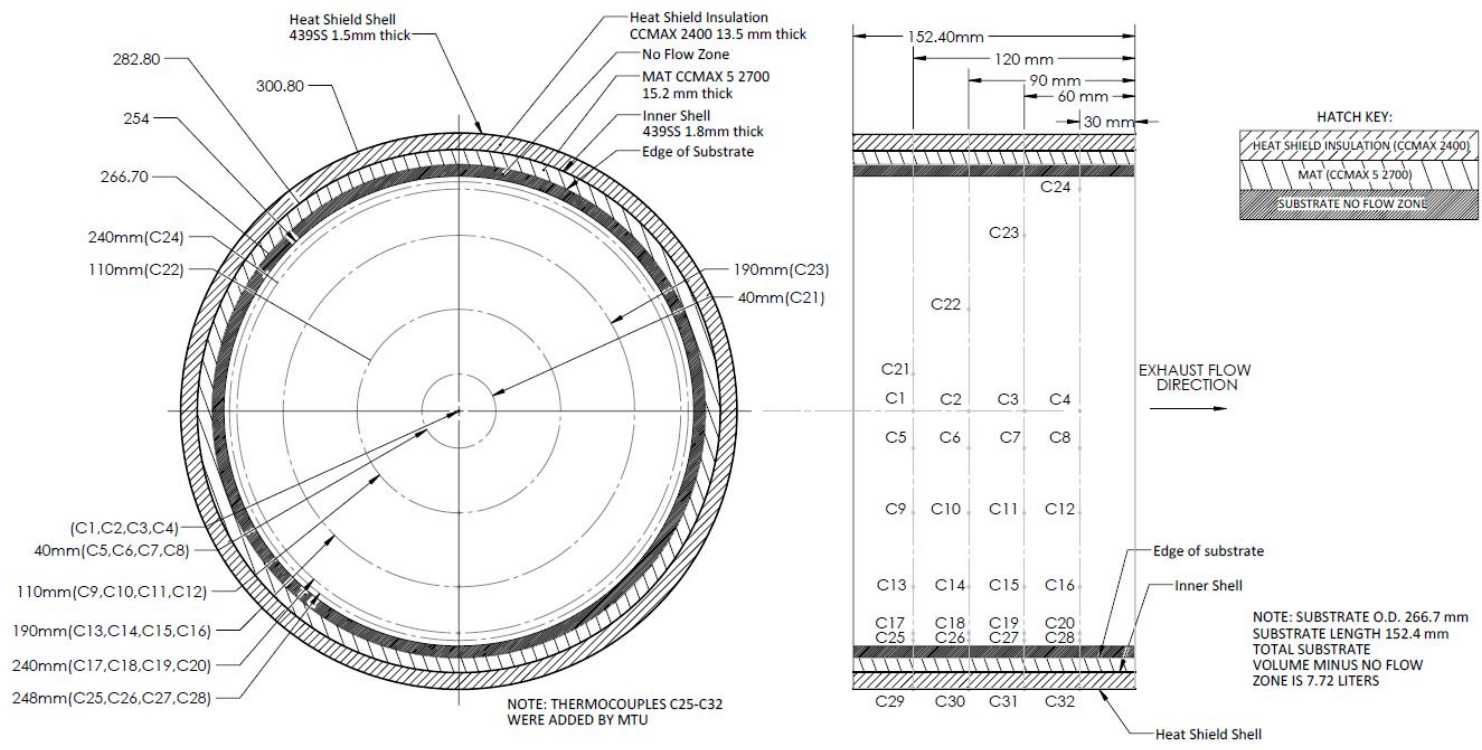

Figure 3.2 dCSC TM Thermocouple Layout

\subsubsection{Pressure Measurement}

Intake air flow is monitored by an engine intake manifold pressure sensor and a laminar flow device upstream of the intake manifold. The laminar flow device's delta pressure is monitored with an Omega high accuracy oil-filled pressure transducer. The dCSC ${ }^{\text {TM }}$ delta pressure is monitored with a similar transducer.

\subsubsection{Emission Analyzers}

Exhaust gas constituents are measured by a number of analyzers. A 5-gas analyzer from Pierburg measures $\mathrm{O}_{2}, \mathrm{CO}_{2}, \mathrm{CO}, \mathrm{NOx}$, and total hydrocarbons. However, the sampling system is not conducive to measuring hydrocarbons; the sample lines are too long and the hydrocarbons get adsorbed on the sample lines. $\mathrm{N}_{2} \mathrm{O}$ concentrations in the exhaust gas are measured by a Thermo Fisher $46 \mathrm{i}_{2} \mathrm{O}$ analyzer. Both the Pierburg 5-gas bench and Thermo Fisher $\mathrm{N}_{2} \mathrm{O}$ analyzer are setup to measure either upstream or downstream dCSC ${ }^{\text {TM }}$ NOx concentrations. This is done by opening a pneumatic valve to either the upstream or downstream sample site and closing the other. There are two production NOx sensors in the system to measure engine out and downstream $\mathrm{dCSC}^{\mathrm{TM}} \mathrm{NOx}$ 
concentrations. A Cambustion $\mathrm{fNOx} 400 \mathrm{CLD}$ is used to measure downstream dCSC ${ }^{\mathrm{TM}}$ NOx and NO concentrations. One of the fNOx400 channels was converted from NO measurement to NOx measurement. See Appendix B for additional details on all of the emission analyzers.

\subsubsection{Data Acquisition Modules}

National instruments NICDAQ modules are used to log temperatures, pressures, flow rates, Cambustion fNOx400 NOx concentrations, and numerous other signals. NI LabVIEW is used to monitor and log these signals as well as control the sampling system for the Pierburg 5-gas bench and the Thermo Fisher 46i $\mathrm{N}_{2} \mathrm{O}$ analyzer. Electronic solenoids, controlled in LabVIEW, allow compressed air to open one-way valves to either an upstream or downstream $\mathrm{dCSC}^{\mathrm{TM}}$ sampling system, for these two analyzers.

\subsection{Test Procedures and Experimental Conditions}

This section lays out specific test procedures that were developed to conduct the experiments and the test conditions for those experiments. The procedures were developed by running test experiments before starting the research testing. During the test experiments, heater PID controls were tuned, engine controls were calibrated, and the overall setup was refined.

\subsubsection{Test Procedure}

Figure 3.3 shows engine load, engine speed, turbine outlet temperature, and the temperature of the thermocouple at the front and middle of the $\mathrm{dCSC} \mathrm{CM}^{\mathrm{TM}}$ substrate $(\mathrm{C} 1$ Thermocouple), during a test. The Phases of every test are illustrated in Figure 3.3 as well. 


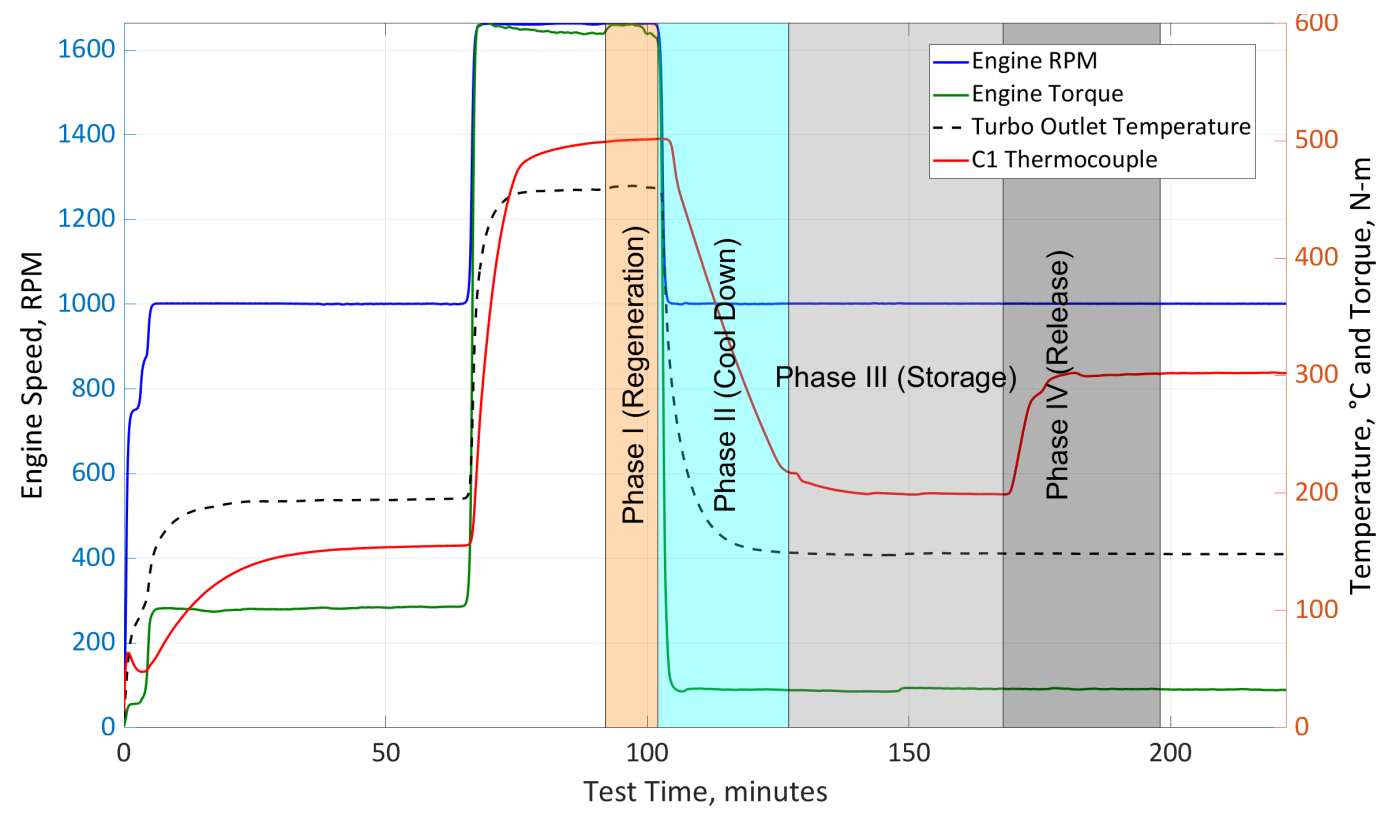

Figure 3.3 dCSC $^{\text {TM }}$ Control Test

Prior to Phase I of the test, the engine is warmed up to a steady state coolant temperature. This ensures the engine-out emissions will be constant during Phases III and IV.

Phase I of the test, is called regeneration. During this Phase, the engine is set to $1660 \mathrm{rpm}$ and $600 \mathrm{~N}-\mathrm{m}$ and exhaust is routed to the aftertreatment system. With the aid of the heater, the $\mathrm{dCSC}^{\mathrm{TM}}$ will reach $500{ }^{\circ} \mathrm{C}$ and will be kept at that temperature for 10 minutes to clean the surface of the substrate and ensure the release of all emissions from the substrate $[1,8,19]$. When the 10 minutes is over, the exhaust is routed directly to the building exhaust and Phase II begins.

During Phase II (Cool Down) the building exhaust is allowed to pull ambient air through the heater to the aftertreatment system. This allows the temperature of the aftertreatment system to be controlled by the heater to the desired temperature for Phase III. During Phase II the engine is also set to the desired condition for the test. The engine will remain at this condition for the remainder of the test. Once the $\mathrm{dCSC} \mathrm{TM}^{\mathrm{TM}}$ is controlled to the desired temperature for Phase III (Storage), the ambient air inlet to the aftertreatment 
system is sealed off. Once the ambient air inlet is sealed off, the exhaust flow is routed to the aftertreatment system. At this time, Phase III (Storage) begins.

Phase III (Storage) is the portion of the test where $\mathrm{dCSC}^{\mathrm{TM}}$ emissions storage capacity is calculated. The $\mathrm{dCSC}^{\mathrm{TM}}$ is controlled to a desired constant temperature for Phase III by the $25-\mathrm{kW}$ heater heating exhaust gas upstream of the dCSC ${ }^{\text {тм }}$. The Pierburg 5-gas bench and the Thermo Fischer $46 \mathrm{i}_{2} \mathrm{O}$ analyzer are both measuring downstream emissions for the entirety of Phases III \& IV. Phase III is 40 minutes long to ensure that the dCSC ${ }^{\text {TM }}$ emissions storage sites are saturated and steady state emissions can be measured. At the conclusion of Phase III, the $25-\mathrm{kW}$ heater is set to heat the exhaust gas upstream of the $\mathrm{dCSC}^{\mathrm{TM}}$ so that the $\mathrm{dCSC}^{\mathrm{TM}}$ temperature will ramp up to a desired constant temperature for Phase IV. As soon as the temperature ramp begins, so does Phase IV.

Phase IV (Release) is the portion of the test where $\mathrm{dCSC}^{\mathrm{TM}}$ emissions' release performance is calculated. Once the $\mathrm{dCSC}{ }^{\mathrm{TM}}$ temperature reaches the desired constant temperature, it is held there for 20 minutes in order to ensure the $\mathrm{dCSC} \mathrm{CM}^{\mathrm{TM}}$ is finished releasing emissions and steady state emissions can be measured.

At the conclusion of Phase IV, the Pierburg 5-gas bench and the Thermo Fischer 46i N2O analyzer are used to measure upstream $\mathrm{dCSC}{ }^{\mathrm{TM}}$ emissions concentrations.

\subsubsection{Engine Test Conditions}

In order to re-create cold start conditions, the three low-load engine conditions shown in Table 3.4 were determined. These are the engine conditions used in Phases III and IV of each experiment, shown in Figure 3.3. The conditions allowed for low dCSC ${ }^{\text {TM }}$ temperatures to be achieved during Phase III (storage phase) of tests. The use of condition 2 was vital to achieving a high $\mathrm{dCSC}^{\mathrm{TM}}$ temperature during Phase IV (release

phase) of tests. Condition 2 was also used to achieve a higher temperature ramp rate of 40 ${ }^{\circ} \mathrm{C} / \mathrm{min}$ from Phase III to Phase IV. The ramp rate was achieved by changing from engine condition 1 to 2 at the beginning of Phase IV. Engine condition 3 was needed in order to achieve $\mathrm{dCSC} \mathrm{CM}^{\mathrm{TM}}$ temperature of $80^{\circ} \mathrm{C}$ during Phase III of a test. Engine condition is set 
before Phase III begins and remains at that condition for the entirety of Phases III and IV. The only exception to the previous statement is the test where a $40{ }^{\circ} \mathrm{C} / \mathrm{min}$ temperature ramp rate was desired. During this test engine condition changes from 1 to 2 at the start of Phase IV, to achieve the temperature ramp rate of $40^{\circ} \mathrm{C} / \mathrm{min}$ in the $\mathrm{dCSC}{ }^{\mathrm{TM}}$. Table 3.4 also shows engine out or upstream $\mathrm{dCSC}{ }^{\mathrm{TM}}$ emissions concentrations at each engine condition, measured by the Pierburg 5-gas bench. The air-to-fuel ratio at each engine condition was calculated from the measured fuel flow and air flow into the engine. They were measured with a Coriolis fuel mass flow rate meter and a laminar flow element instrumented to measure air mass flow rate. The $\mathrm{H}_{2} \mathrm{O}$ concentration out of the engine was calculated using the AFR and the fuel properties from Table 3.2.

Table 3.4 Engine Test Conditions

\begin{tabular}{|c|c|c|c|}
\hline Engine Parameter & $\begin{array}{c}\text { Condition } \\
1\end{array}$ & $\begin{array}{c}\text { Condition } \\
2\end{array}$ & $\begin{array}{c}\text { Condition } \\
3\end{array}$ \\
\hline Speed (rpm) & 1000 & 1290 & 750 \\
\hline Load (N-m) & 35 & 46 & 22 \\
\hline Exhaust Flow Rate (kg/min) & 3.5 & 4.9 & 2.6 \\
\hline Turbine Outlet Temperature $\left({ }^{\circ} \mathrm{C}\right)$ & 140 & 180 & 110 \\
\hline Air-to-Fuel Ratio (AFR) & 100 & 83 & 130 \\
\hline $\mathrm{EGR}(\%)$ & 0 & 0 & 0 \\
\hline $\mathrm{O}_{2}(\%)$ & 17.5 & 17.1 & 18.0 \\
\hline $\mathrm{CO} 2(\%)$ & 2.5 & 2.9 & 1.8 \\
\hline $\mathrm{H}_{2} \mathrm{O}(\%)$ & 1.9 & 2.3 & 1.5 \\
\hline $\mathrm{CO}^{(\mathrm{ppm})}$ & 86 & 95 & 75 \\
\hline $\mathrm{NO}_{(\mathrm{ppm})}$ & 175 & 209 & 211 \\
\hline $\mathrm{NO} 2(\mathrm{ppm})$ & 10 & 7 & 18 \\
\hline $\mathrm{NOx}_{(\mathrm{ppm})}$ & 185 & 216 & 229 \\
\hline
\end{tabular}




\subsubsection{Experimental Test Conditions}

Table 3.5 shows a list of desired dCSC ${ }^{\mathrm{TM}}$ temperatures for Phase III. These temperatures were decided upon based on findings from other dCSCTM, PNA, and DOC research publications $[1,8,17,18,24]$. Refer to Chapter 2 Figure 2.8 for temperatures tested on the $\mathrm{dCSC}^{\mathrm{TM}}$ in reference [8]. These tests were all conducted with a $\mathrm{dCSC} \mathrm{CM}^{\mathrm{TM}}$ temperature of $300{ }^{\circ} \mathrm{C}$ during Phase IV of the test.

Table 3.5 Emissions Storage Test Plan

\begin{tabular}{|c|c|}
\hline Engine Test Condition & $\begin{array}{c}\text { Phase III (Storage) Emissions } \\
\text { Temperature, }{ }^{\circ} \mathrm{C}\end{array}$ \\
\hline 1 & $100,125^{*}, 150,200,225,250$ \\
\hline 2 & $115,150,200,250$ \\
\hline 3 & 80 \\
\hline
\end{tabular}

The use of "**" next to a number in Tables 3.5-3.7 indicates that the test is a repeat of a test in one of the other two tables.

Based on downstream dCSCTM ATS operating temperatures, a list of desired dCSC ${ }^{\mathrm{TM}}$ temperatures was determined for Phase IV of the $\mathrm{dCSC}^{\mathrm{TM}}$ testing. This list of temperatures is referred to as the emissions release/conversion test plan in Table 3.6. The $\mathrm{dCSC}^{\mathrm{TM}}$ temperature during Phase III and engine condition for Phases III and IV is in Table 3.6 as well. Engine condition 1 and $150^{\circ} \mathrm{C}$ Phase III (storage) dCSCTM temperature was tested at $200-450^{\circ} \mathrm{C}$ Phase IV (release) $\mathrm{dCSC}^{\mathrm{TM}}$ temperatures. This was done in order to characterize the temperature of the $\mathrm{dCSC}^{\mathrm{TM}} \mathrm{vs}$. its ability to regain its NOx storage capacity.

Table 3.6 Emissions Release/Conversion Test Plan

\begin{tabular}{|c|c|}
\hline $\begin{array}{c}\text { Engine Test Condition } \\
\text { \& Phase III (Storage) } \\
\text { Temperature, }{ }^{\circ} \mathrm{C}\end{array}$ & $\begin{array}{c}\text { Phase IV (Release) Emissions } \\
\text { Temperature, }{ }^{\circ} \mathrm{C}\end{array}$ \\
\hline Condition $1 \& 150$ & $200,250,300^{*}, 350^{*}, 400,450$ \\
\hline Condition $2 \& 150$ & $300^{*}, 350$ \\
\hline Condition 1 \& 125 & $300^{*}$ \\
\hline Condition 1\&200 & $300^{*}, 400$ \\
\hline
\end{tabular}

The use of "*”" next to a number in Tables 3.5-3.7 indicates that the test is a repeat of a test in one of the other two tables. 
Testing was completed to compare the release/conversion performance to temperature ramp rate. Two tests were run with the same Phase III and Phase IV temperature setpoints, but with different temperature ramp rates between the two. Details of these two tests are in Table 3.7. The first test was completed with a ramp rate of $20{ }^{\circ} \mathrm{C} / \mathrm{min}$ and the second with a rate of $40{ }^{\circ} \mathrm{C} / \mathrm{min}$. In order to achieve the $40{ }^{\circ} \mathrm{C} / \mathrm{min}$ ramp rate, the engine condition changes from condition 1 to 2 at the conclusion of Phase III and the start of Phase IV.

Table 3.7 Emissions Release/Conversion vs. Temperature Ramp Test Plan

\begin{tabular}{|c|c|c|c|}
\hline $\begin{array}{c}\text { Engine Test } \\
\text { Condition \& Phase } \\
\text { III (Storage) } \\
\text { Temperature, }{ }^{\circ} \mathrm{C}\end{array}$ & $\begin{array}{c}\text { Ramp Rate, } \\
{ }^{\circ} \mathrm{C} / \text { minute }\end{array}$ & $\begin{array}{c}\text { Engine Test } \\
\text { Condition \& Phase } \\
\text { IV (Release) } \\
\text { Temperature, }{ }^{\circ} \mathrm{C}\end{array}$ & $\begin{array}{c}\text { Ramp } \\
\text { Time, } \\
\text { minutes }\end{array}$ \\
\hline Condition $1 \& 150^{*}$ & 20 & Condition $1 \& 350$ & 10 \\
\hline Condition $1 \& 150$ & 40 & Condition $2 \& 350$ & 5 \\
\hline
\end{tabular}

A complete list of tests that were run can be found in Appendix D. A MATLAB vector containing the numbers 1 through 25 was randomized using the command 'randperm' to generate the test run order. In between each test in the run order, test 4, the control test, was run. The control test is performed at engine condition $1,200{ }^{\circ} \mathrm{C}$ Phase III $\mathrm{dCSC}^{\mathrm{TM}}$ temperature, and a $300{ }^{\circ} \mathrm{C}$ Phase IV dCSCTM temperature.

\subsubsection{ATS Thermal Management}

Characterizing the $\mathrm{dCSC}{ }^{\mathrm{TM}}$ performance at different temperatures is presented in Chapter 4. The data will be used to calibrate a model of the $\mathrm{dCSC} \mathrm{CM}^{\mathrm{TM}}$ characteristics at different temperatures. Therefore, controlling the ATS temperature during the experiments is vital. Figure 3.4 shows the system (also shown in Figure 3.1) for controlling the temperature in the ATS. 


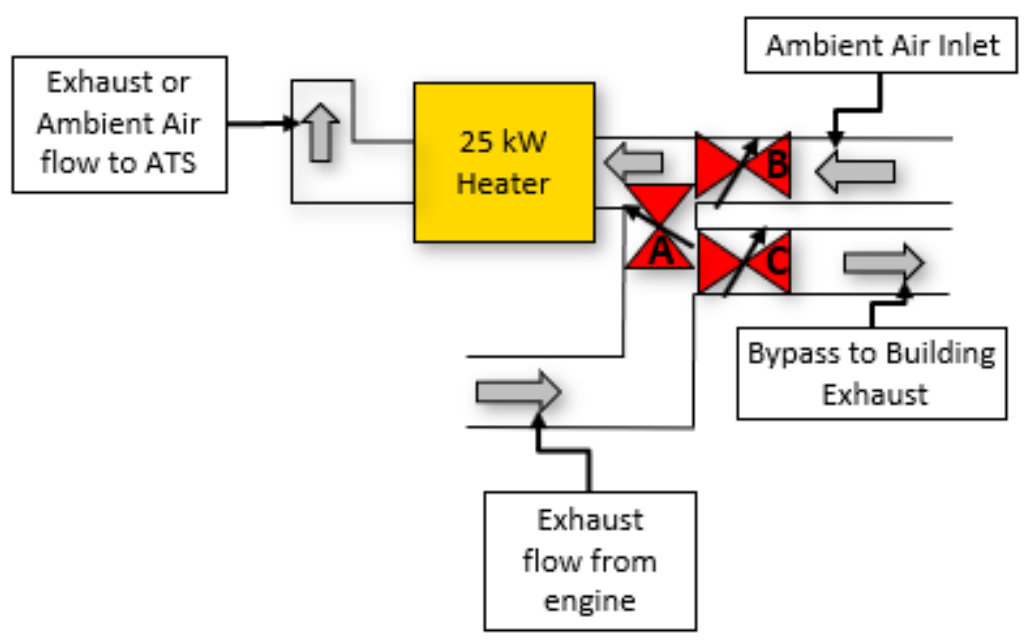

Figure 3.4 ATS Thermal Management

The exhaust flow from the 2013 Cummins ISB engine can be routed to the ATS by closing valves $\mathrm{C}$ and $\mathrm{B}$ and opening valve $\mathrm{A}$. The exhaust can also be routed directly to the building's exhaust by closing valve $\mathrm{A}$ and opening valve $\mathrm{C}$. While valve $\mathrm{A}$ is closed, valve $B$ can be opened to allow ambient air to be pulled through the ATS. This strategy is utilized to cool the ATS while also controlling the ATS temperature with the $25-\mathrm{kW}$ heater. This allows the $\mathrm{dCSC} \mathrm{CM}^{\mathrm{TM}}$ temperature to be controlled and stabilized at the desired temperature for Phase III of the test. This strategy also minimizes the possibility of the building exhaust vacuum pulling engine exhaust past valve A when it is closed. This is because the building exhaust will be able to pull ambient air through an open valve B rather than deadheading on valve $\mathrm{A}$.

Figure 3.5 shows the $\mathrm{dCSC}^{\mathrm{TM}}$ temperatures and a calculated $\mathrm{dCSC} \mathrm{TM}^{\mathrm{TM}}$ volume weighted temperature. Equation 3.7 and Appendix E describe how the volume weighted temperature is calculated. In Figure 3.5 the $\mathrm{dCSC}^{\mathrm{TM}}$ temperatures are measured by thermocouples C1, C2, and C18. The location of these thermocouples is shown in Figure 3.2. $\mathrm{C} 1$ and $\mathrm{C} 4$ are located on the centerline of the $\mathrm{dCSC}{ }^{\text {TM }}$ substrate. $\mathrm{C} 1$ is $32.4 \mathrm{~mm}$ from the upstream face and $\mathrm{C} 4$ is $30 \mathrm{~mm}$ from the downstream face of the substrate. $\mathrm{C} 18$ is $120 \mathrm{~mm}$ radially from the center of the $\mathrm{dCSC}^{\mathrm{TM}}$ and $30 \mathrm{~mm}$ downstream of $\mathrm{C} 1$, axially. 
The thermocouple data in Figure 3.5 shows how the $\mathrm{dCSC}^{\mathrm{TM}}$ temperature is accurately and actively controlled during the experiment.

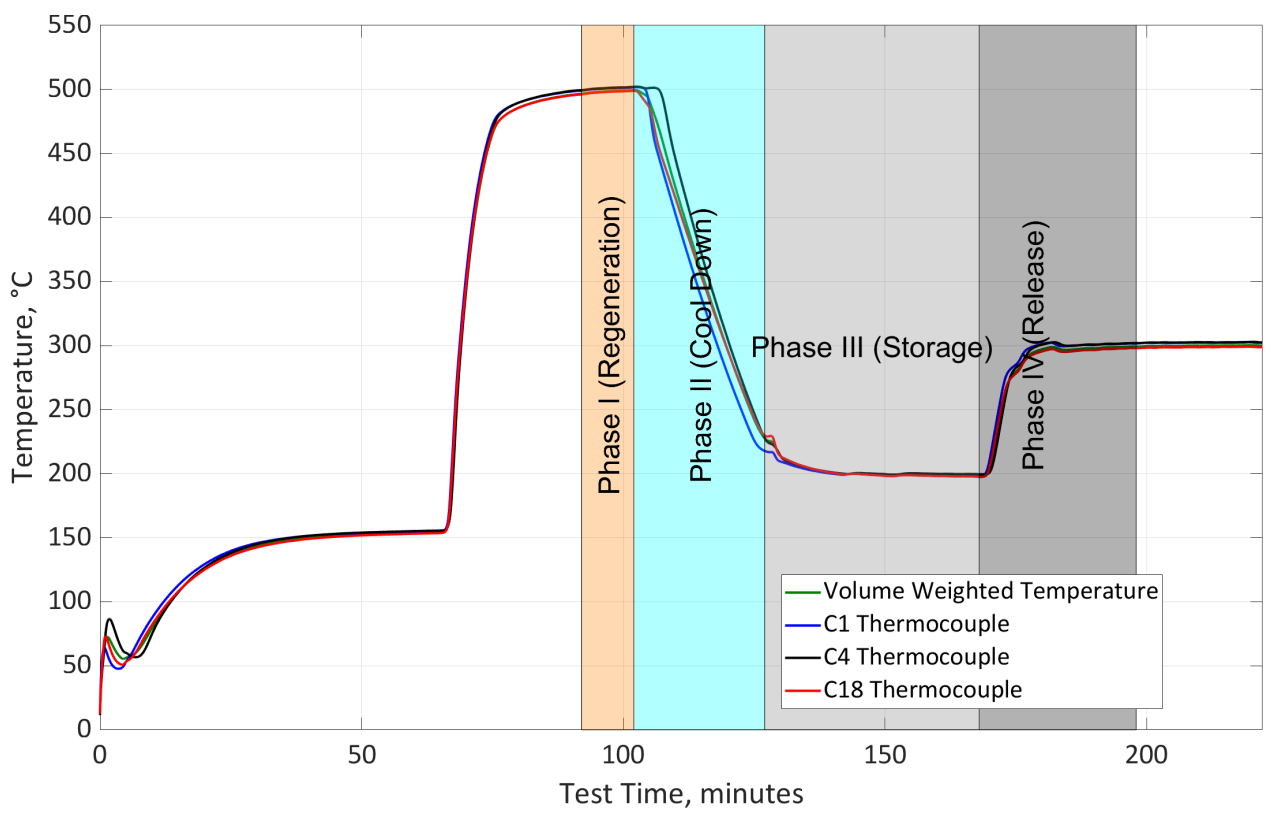

Figure 3.5 dCSCTM Exhaust Temperatures During a Control Test

\subsection{Data Analysis Methods}

The equations in this section were used in the postprocessing of the experimental data. The results from these equations were used to quantify the $\mathrm{dCSC}^{\mathrm{TM}}$ performance characteristics. Chapter 4 covers the results that were computed using these equations.

\subsubsection{Adsorption and Desorption Calculations (Storage/Release)}

The following equations were used to calculate the NOx storage and release, $\mathrm{N}_{2} \mathrm{O}$ production, and $\mathrm{NO}_{2}$ to $\mathrm{NOx}$ ratio at the $\mathrm{dCSC}^{\mathrm{TM}}$ outlet. Equation 3.1 is used to calculate the molar flow rate of the exhaust.

$$
\dot{n}_{\text {exhaust }}=\frac{\dot{m}_{\text {exhaust }}}{M_{\text {exhaust }}}
$$


Where, $\dot{n}_{\text {exhaust }}$ is the molar flow rate of the exhaust. $\dot{m}_{\text {exhaust }}$ is the mass flow rate of the exhaust which is equal to the measured $\dot{m}_{\text {air }}$ plus the $\dot{m}_{\text {fuel }}$. The $M_{\text {exhaust }}$ is the molecular weight of the exhaust. The molecular weight of the exhaust used was 28.97 per reference [25]. After calculating the molar flow rate of the exhaust, the molar flow rate of NOx in the exhaust is calculated using Equation 3.2.

$$
\dot{n}_{N O x}=\dot{n}_{\text {exhaust }} * \frac{C_{N O x}}{1,000,000}
$$

Where $\dot{n}_{N O X}$ is the molar flow rate of NOx, and $C_{N O X}$ is the concentration of NOx in the exhaust. A more general form of Equation 3.2 is Equation 3.3, which can be used to calculate the molar flow rate of any exhaust gas constituent.

$$
\dot{n}_{X}=\dot{n}_{\text {exhaust }} * \frac{C_{X}}{1,000,000}
$$

Where $\dot{n}_{X}$ is the molar flow rate of any exhaust gas constituent $\mathrm{x}$ and $C_{X}$ is the exhaust gas concentration of that constituent, $x$. Using the molar flow rate of a species in the exhaust, in this case it is NOx, the species' storage, release, or production can be calculated using Equation 3.4.

$$
n_{\text {NOx Stored }}=\sum_{i=t_{i}}^{t_{f}}\left(\dot{n}_{N O x \operatorname{In}(i)}-\dot{n}_{\text {NOx Out }(i)}\right) * \Delta t
$$

Where, $n_{\text {NOx stored }}$ is the moles of NOx stored. The sampling increment $(\Delta t)$ is 0.5 seconds or $2 \mathrm{~Hz}$. The summation for $n_{\text {NOx Stored }}$ is computed from the start of Phase III $\left(t_{i}\right)$ to the time at which downstream $\mathrm{dCSC}^{\mathrm{TM}} \mathrm{NOx}$ concentrations are equal to the upstream dCSC ${ }^{\mathrm{TM}}$ NOx concentrations $\left(t_{f}\right)$. NOx storage in mass units can be computed by multiplying the moles of NOx stored ( $n_{\mathrm{NOx}}$ stored $)$ by the molecular weight of $\mathrm{NO}_{2}$ which is the definition of $\mathrm{x}=2$ (44.01). The molecular weight of $\mathrm{NO}_{2}$ is used to calculate NOx stored because once NOx reaches the atmosphere the NO portion will be oxidized into $\mathrm{NO}_{2} \cdot \dot{n}_{\text {NOx In (i) }}$ is the molar flow rate of NOx into the $\mathrm{dCSC}^{\mathrm{TM}}$ and $\dot{n}_{\text {NOx out }(i)}$ is 
the molar flow rate of NOx out of the $\mathrm{dCSC}^{\mathrm{TM}}$. Equation 3.5 is used to calculate the moles of $\mathrm{N}_{2} \mathrm{O}$ produced.

$$
n_{N_{2} O \text { Produced }}=\sum_{i=t_{i}}^{t_{f}}\left(\dot{n}_{N_{2} O \text { In }(i)}-\dot{n}_{N_{2} O \text { out }(i)}\right) * \Delta t
$$

Where, $n_{N_{2} O}$ Produced is the moles of $\mathrm{N}_{2} \mathrm{O}$ produced. $\dot{n}_{N_{2} O}$ In is the molar flow rate of $\mathrm{N}_{2} \mathrm{O}$ into the dCSCTM and $\dot{n}_{N_{2} O}$ out is the molar flow rate of $\mathrm{N}_{2} \mathrm{O}$ out of the dCSC ${ }^{\mathrm{TM}} . \mathrm{N}_{2} \mathrm{O}$ molar flow rate is calculated using Equation 3.3 and the $\mathrm{N}_{2} \mathrm{O}$ concentration $\left(C_{\mathrm{N}_{2} \mathrm{O}}\right)$.

During Phase III of the experiments, the downstream dCSC ${ }^{\text {TM }}$ NOx concentration increases from 0 ppm NOx to the upstream $\mathrm{dCSC}^{\mathrm{TM}} \mathrm{NOx}$ concentration. The point at which the downstream NOx concentration is exactly $50 \%$ of the upstream concentration (where the ratio is 0.5 ) is referred to as $\mathrm{dCSC} \mathrm{CM}^{\mathrm{TM}} 50 \% \mathrm{NOx}$ storage capacity. The ratio of the $\mathrm{dCSC}^{\mathrm{TM}}$ downstream NOx concentration to the upstream NOx concentration (dCSCTM NOx inlet to outlet ratio) is calculated using Equation 3.6.

$$
\frac{N O x_{\text {out }}}{N O x_{\text {In }}}=\frac{C_{N O_{\mathrm{x} O u t}}}{C_{N O x_{\text {In }}}}
$$

Where, $\frac{N O x_{\text {Out }}}{N O x_{I n}}$ is the ratio of the dCSCTM downstream NOx concentration to the upstream concentration. $C_{N O_{\mathrm{x} O u t}}$ is the downstream dCSC ${ }^{\mathrm{TM}} \mathrm{NOx}$ concentration and $C_{N O x_{I n}}$ is the upstream NOx concentration. 


\subsubsection{Calculation of $\mathrm{NO}_{2}$ to NOx Ratio (NO Conversion Efficiency)}

Equation 3.7 is used to calculate $\mathrm{NO}_{2}$ to $\mathrm{NOx}$ ratio at the outlet of the $\mathrm{dCSC}$ TM. This allows for the characterization of the NOx oxidation characteristics of the $\mathrm{dCSC} \mathrm{CM}^{\mathrm{TM}}$ during the steady state portions of Phases III and IV.

$$
\frac{\mathrm{NO}_{2}}{N O x}=\frac{C_{N O_{2} \text { out }}}{C_{\text {NOx }} \text { out }}
$$

Where $\frac{\mathrm{NO}_{2}}{\mathrm{NOX}}$ is the $\mathrm{NO}_{2}$ to $\mathrm{NOx}$ ratio at the $\mathrm{dCSC} \mathrm{CM}^{\mathrm{TM}}$ outlet, $\mathrm{C}_{\mathrm{NO}_{2} \text { out }}$ is the concentration of $\mathrm{NO}_{2}$ at the dCSC ${ }^{\mathrm{TM}}$ outlet, and $C_{N O x_{\text {out }}}$ is the concentration of NOx at the $\mathrm{dCSC}$ TM outlet. In Figure 3.6, the outlet concentration is greater for $\mathrm{NO}_{2}$ than $\mathrm{NO}$ during Phase IV. This is because the substrate temperatures during these two phases are high enough to oxidize a large portion of the upstream $\mathrm{NO}$ to downstream $\mathrm{NO}_{2}$.
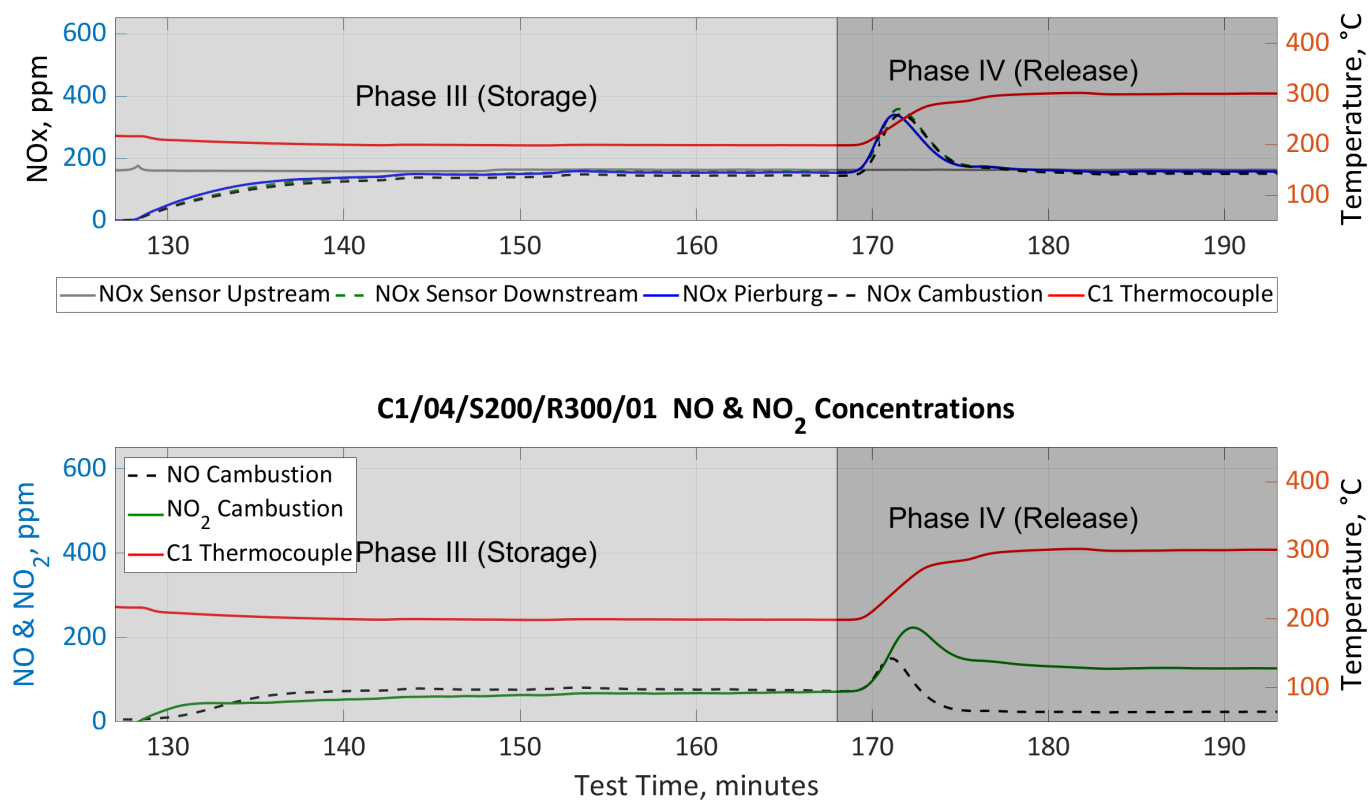

Figure 3.6 Downstream dCSC ${ }^{\mathrm{TM}} \mathrm{NO}, \mathrm{NO}_{2}$, and $\mathrm{NOx}$ Concentrations during a $200{ }^{\circ} \mathrm{C}$

Phase III and $300{ }^{\circ} \mathrm{C}$ Phase IV 
The NOx Storage is computed using the downstream NOx concentration versus time from the Pierburg CLD, Cambustion CLD, NOx sensor, and two upstream NOx concentrations from the Pierburg and NOx sensor.

\subsubsection{Calculation of dCSC $^{\mathrm{TM}}$ Volume Weighted Temperature}

$\mathrm{dCSC}^{\mathrm{TM}}$ volume weighted temperature is calculated using Equation 3.8.

$$
T_{V . W .}=\sum_{i=1}^{24}\left(W_{\text {T.C. }(i)} * T_{\text {T.C. }(i)}\right)
$$

Where $T_{V . W}$. is the $\mathrm{dCSC}^{\mathrm{TM}}$ volume weighted temperature, $W_{\text {T.C.(i) }}$ is the weight applied to each thermocouple, and $T_{\text {T.C. (i) }}$ is the thermocouple temperature reading. The weight applied to each thermocouple is calculated using Equation 3.9.

$$
W_{\text {T.C. }}=\frac{V_{T . C .}}{V_{T . V .}}
$$

Where, $W_{T . C .}$ is the weight applied to each thermocouple reading. $V_{\text {T.C. }}$ is the volume that each thermocouple represents and $V_{T . V}$. is the total volume of instrumented dCSCTM. Appendix E is a detailed explanation of the $\mathrm{dCSC}^{\mathrm{TM}}$ volume weighted temperature calculation.

\subsection{4 dCSC ${ }^{\text {TM }}$ 2D Temperature Distribution}

The top half of the $\mathrm{dCSC}{ }^{\mathrm{TM}}$ is instrumented with $32 \mathrm{~K}$-type omega thermocouples, as shown in Figure 3.2. The temperature data from thermocouples $\mathrm{C} 1$ through $\mathrm{C} 20$ are used to plot a $2 \mathrm{D}$ temperature distribution of the top half of the $\mathrm{dCSC}^{\mathrm{TM}}$. This plot is then mirrored across the centerline of the $\mathrm{dCSC}{ }^{\mathrm{TM}}$ to illustrate the entire substrate temperature distribution. Thermocouples $\mathrm{C} 22,23$, and $\mathrm{C} 24$ are instrumented on the bottom half of the $\mathrm{dCSC}^{\mathrm{TM}}$. The RMS Error in the plot title is computed using the difference between these three thermocouples and the mirrored 2D temperature distribution. A MATLAB code 
was written to plot the temperature distribution using the command 'contourf.' The 'contourf' command plots each thermocouple reading at its axial and radial location within the substrate. The resulting distribution assumes a linear temperature gradient in between the thermocouple readings. Thermocouples C13-C16 were not used to create the 2D temperature distributions. Because it was assumed a maldistribution in the exhaust flow upstream of the $\mathrm{dCSC}^{\mathrm{TM}}$ caused this row of thermocouples to be at a higher temperature than the thermocouples radially inward of this row. Figure 3.7 shows the $\mathrm{dCSC}^{\text {TM }} 2 \mathrm{D}$ temperature distribution during Phase III of a test where the temperature setpoint was $200^{\circ} \mathrm{C}$.

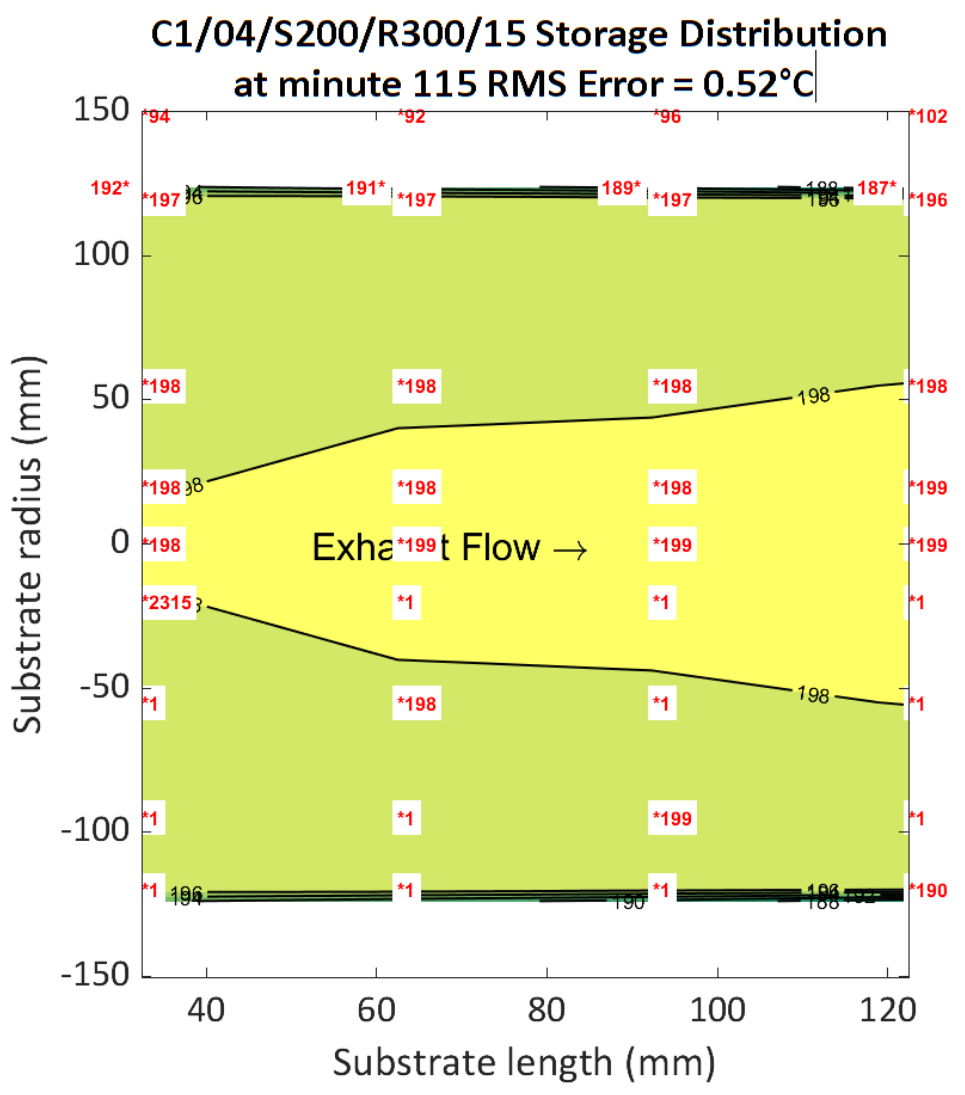

Figure 3.7 Control Test 15 at minute 115 , dCSC TM Temperature $200^{\circ} \mathrm{C}$, Phase III $2 \mathrm{D}$ Temperature Distribution

The numbers in red indicate the actual thermocouple readings in the $\mathrm{dCSC}{ }^{\mathrm{TM}}$. Each *1's in red font indicates a location in the $\mathrm{dCSC}^{\mathrm{TM}}$ where there is no thermocouple. 


\section{Results}

This chapter presents the experimental data results from Phases III and IV. These two Phases are the portions of the testing where emissions storage, release, and oxidation were observed and analyzed. Section 4.1 discusses the emissions time plots during experiment Phases III and IV. Appendix F shows the measured emissions concentrations, engine parameters, delta pressures, and temperatures vs. time during a test. Appendix G shows the control parameters measured for each test such as upstream $\mathrm{dCSC} \mathrm{CM}^{\mathrm{TM}}$ emissions concentrations, exhaust mass flow rate, intake air mass flow rate, etc.

Section 4.2 discusses the $\mathrm{NO}, \mathrm{NO}_{2}$, and $\mathrm{NOx}$ storage/adsorption performance of the $\mathrm{dCSC}^{\mathrm{TM}}$ for a range of temperatures from 80 to $250^{\circ} \mathrm{C}$, during Phase III of the testing. Section 4.3 discusses the $\mathrm{NO}, \mathrm{NO}_{2}$, and $\mathrm{NOx}$ release/desorption performance of the $\mathrm{dCSC}^{\mathrm{TM}}$ for a range of temperatures from 200 to $450^{\circ} \mathrm{C}$, during Phase IV the of testing. Section 4.4 shows the dCSC ${ }^{\text {TM }} \mathrm{NO}$ to $\mathrm{NO}_{2}$ oxidation characteristics. dCSC ${ }^{\mathrm{TM}} \mathrm{NO}$ to $\mathrm{NO}_{2}$ oxidation was calculated during Phases III and IV of testing, after the transient NOx storage or release event. During NOx release at the beginning of Phase IV, an $\mathrm{N}_{2} \mathrm{O}$ concentration is observed downstream of the $\mathrm{dCSC}^{\mathrm{TM}}$ and section 4.5 discusses this production of $\mathrm{N}_{2} \mathrm{O}$. The dCSCTM $\mathrm{CO}$ storage/oxidation characteristics are discussed in section 4.6. Appendices $\mathrm{H}$ and I discuss the $\mathrm{N}_{2} \mathrm{O}$ formulation and oxidation reactions in the $\mathrm{dCSC}^{\mathrm{TM}}$, respectively

$\mathrm{dCSC}^{\mathrm{TM}} 2 \mathrm{D}$ temperature distribution data were measured during Phases III and IV of testing and were plotted using the methodology described in 3.4.4. Section 4.7 presents the $2 \mathrm{D}$ temperature distribution plots of the $\mathrm{dCSC} \mathrm{CM}^{\mathrm{TM}}$ temperatures. Throughout the figures in this chapter, the $\mathrm{C} 1$ thermocouple within the $\mathrm{dCSC} \mathrm{CM}^{\mathrm{TM}}$ is referenced to represent the $\mathrm{dCSC}{ }^{\mathrm{TM}}$ temperature. It was determined that additional thermocouples are needed to accurately capture the temperature gradient in the substrate, Appendix J discusses this.

Section 4.8 is the Summary and Conclusions of the results and Section 4.9 discusses recommendations for future work. 


\subsection{Test Phases III and IV Emissions Data}

Figure 4.1 shows the $\mathrm{NO}, \mathrm{NO}_{2}, \mathrm{NOx}, \mathrm{CO}$, and $\mathrm{N}_{2} \mathrm{O}$ concentrations at the outlet of the $\mathrm{dCSC}^{\mathrm{TM}}$ during a test with temperatures of $115^{\circ} \mathrm{C}$ during Phase III and $300^{\circ} \mathrm{C}$ during Phase IV. The NO and NOx are measured by the Cambustion Fast Response CLD analyzer. $\mathrm{NO}_{2}$ is calculated by subtracting the measured $\mathrm{NO}$ from the measured $\mathrm{NOx}$. $\mathrm{CO}$ is measured by the Pierburg 5-gas bench and $\mathrm{N}_{2} \mathrm{O}$ is measured by the Thermo Fisher $46 \mathrm{i}$ $\mathrm{N}_{2} \mathrm{O}$ analyzer. Before the start of Phase III, the $\mathrm{dCSC}^{\mathrm{TM}}$ has been controlled to $115^{\circ} \mathrm{C}$ via the $25-\mathrm{kW}$ electric heater. Once the temperature in the $\mathrm{dCSC} \mathrm{CM}^{\mathrm{TM}}$ stabilizes at $115^{\circ} \mathrm{C}$, exhaust gas is routed to the $\mathrm{dCSC} \mathrm{CM}^{\mathrm{TM}}$ and Phase III begins.

During Phase III, NO and NOx concentrations at the $\mathrm{dCSC} \mathrm{CM}^{\mathrm{TM}}$ outlet start at $0 \mathrm{ppm}$ and increase until they reach the upstream $\mathrm{dCSC}^{\mathrm{TM}}$ concentration of $\mathrm{NO}$ and $\mathrm{NOx}$, indicating $\mathrm{NO}$ and $\mathrm{NO}_{2}$ storage. At a temperature of $115^{\circ} \mathrm{C}$, there is zero $\mathrm{NO}$ to $\mathrm{NO}_{2}$ oxidation occurring in the $\mathrm{dCSC}^{\mathrm{TM}}$ and the upstream NOx is comprised of $99 \%$ NO. Therefore, 0 ppm $\mathrm{NO}_{2}$ is measured at the $\mathrm{dCSC}^{\mathrm{TM}}$ outlet. $\mathrm{CO}$ concentrations downstream of the $\mathrm{dCSC}^{\mathrm{TM}}$ start at $0 \mathrm{ppm}$ and increase until they reach approximately $40 \mathrm{ppm}$. The upstream $\mathrm{dCSC}{ }^{\mathrm{TM}} \mathrm{CO}$ concentration during this test was approximately $85 \mathrm{ppm}$. This indicates a storage and oxidation of $\mathrm{CO}$ on the $\mathrm{dCSC} \mathrm{CM}^{\mathrm{TM}}$. After the $\mathrm{dCSC} \mathrm{CM}^{\mathrm{TM}}$ has finished storing emissions and the concentrations have reached steady state, steady state concentrations are recorded.

During Phase IV, $\mathrm{dCSC}^{\mathrm{TM}}$ temperature increases from 115 to $300{ }^{\circ} \mathrm{C}$. As the temperature is increasing and reaches approximately $200^{\circ} \mathrm{C}$, the $\mathrm{NO}$ and NOx concentrations start increasing, indicating NOx release. The concentrations peak at approximately $450 \mathrm{ppm}$ as the $\mathrm{dCSC} \mathrm{CM}^{\mathrm{TM}}$ temperature reaches $250^{\circ} \mathrm{C}$ and then decrease to a steady state concentration. Once the $\mathrm{dCSC}{ }^{\mathrm{TM}}$ temperature reaches approximately $220^{\circ} \mathrm{C}$, the $\mathrm{NO}_{2}$ concentration starts increasing, and the $\mathrm{dCSC} \mathrm{CM}^{\mathrm{TM}}$ is now at a high enough temperature to oxidize some of the stored $\mathrm{NO}$ to $\mathrm{NO}_{2}$ while releasing it. The $\mathrm{NO}_{2}$ concentration peaks as the temperature reaches $265^{\circ} \mathrm{C}$ and then decreases to a steady state concentration of approximately $110 \mathrm{ppm}$. The NOx concentration returns to its initial value of 
approximately $150 \mathrm{ppm}$, and the NO concentration reaches a steady state concentration of about $40 \mathrm{ppm}$. The steady state $\mathrm{NO}_{2}$ concentration is more than double the $\mathrm{NO}$ concentration, indicating over half of the NO entering the substrate is being oxidized to $\mathrm{NO}_{2}$. These steady state concentrations from each test are used to compute the downstream dCSC ${ }^{\text {TM }} \mathrm{NO}_{2} / \mathrm{NOx}$ ratio at each Phase IV temperature. As soon as the $\mathrm{dCSC}^{\mathrm{TM}}$ temperature starts increasing, the $\mathrm{CO}$ concentration downstream of the $\mathrm{dCSC} \mathrm{CM}^{\mathrm{TM}}$ starts to decrease and reaches $0 \mathrm{ppm}$ by the time the temperature reaches approximately $150{ }^{\circ} \mathrm{C}$. The $\mathrm{dCSC} \mathrm{CM}^{\mathrm{TM}}$ is then oxidizing all the upstream $\mathrm{CO}$ to downstream $\mathrm{CO}_{2}$. A concentration of $\mathrm{N}_{2} \mathrm{O}$ is observed at the $\mathrm{dCSC}^{\mathrm{TM}}$ outlet as the temperature approaches 200 ${ }^{\circ} \mathrm{C}$. This concentration increases from $0 \mathrm{ppm}$ to a peak of approximately $14 \mathrm{ppm}$ as the $\mathrm{dCSC}^{\mathrm{TM}}$ reaches $230^{\circ} \mathrm{C}$ and then decreases back to $0 \mathrm{ppm}$. The concentration of $\mathrm{N}_{2} \mathrm{O}$ at the $\mathrm{dCSC}^{\mathrm{TM}}$ outlet is due to a small occurrence of $\mathrm{HC}$ lean NOx conversion occurring within the $\mathrm{dCSC} \mathrm{CM}^{\mathrm{TM}}$, this is supported in reference [1].
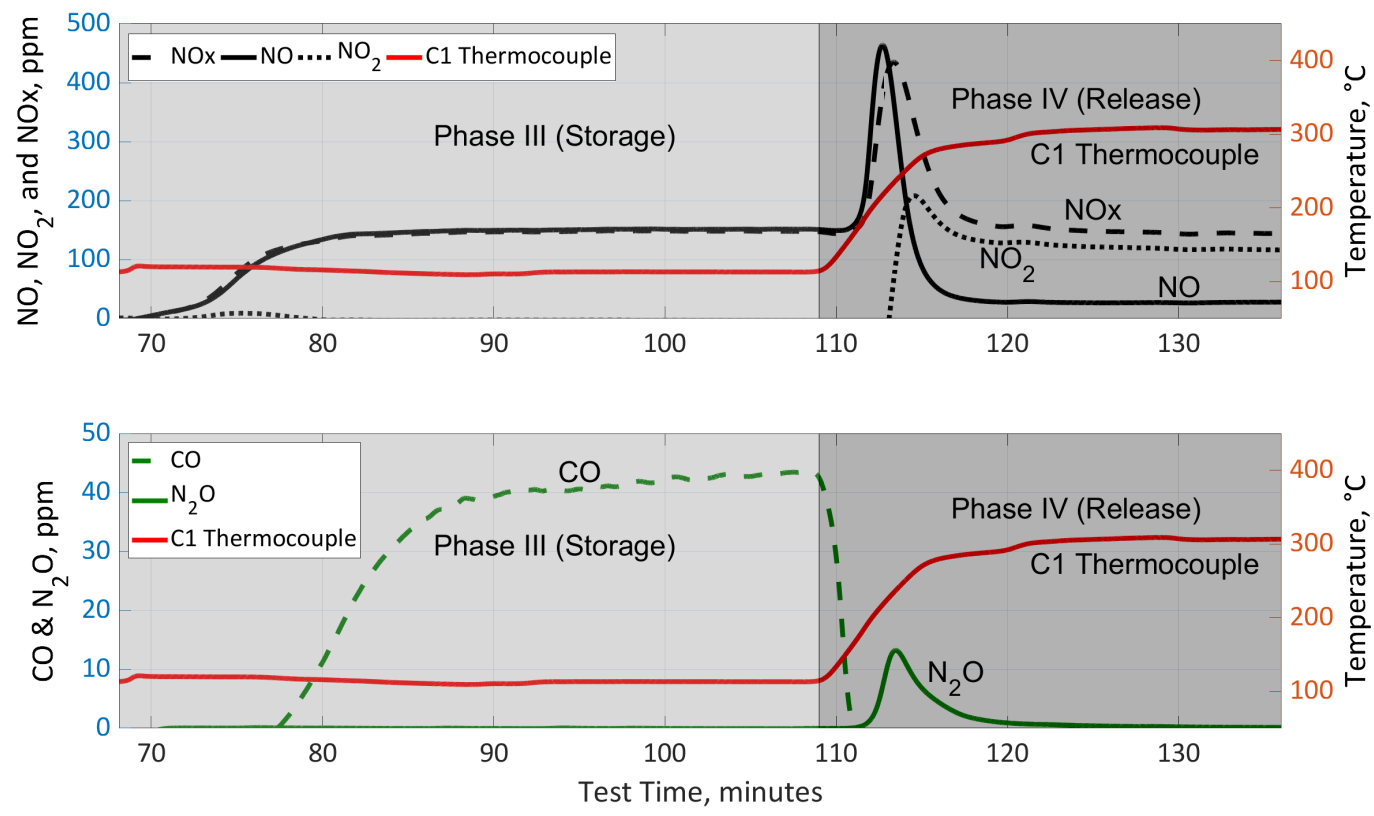

Figure 4.1 NO, $\mathrm{NO}_{2}, \mathrm{NOx}, \mathrm{CO}$, and $\mathrm{N}_{2} \mathrm{O}$ Concentrations Downstream of the dCSC ${ }^{\mathrm{TM}}$ during a $115^{\circ} \mathrm{C}$ Phase III and a $300{ }^{\circ} \mathrm{C}$ Phase IV, at Engine Condition 1 


\subsection{NO, $\mathrm{NO}_{2}$, and NOx Storage Performance}

NOx concentrations upstream of the $\mathrm{dCSC}^{\mathrm{TM}}$ were measured using both the NOx sensor and the Pierburg CLD. NOx concentrations downstream of the $\mathrm{dCSC}{ }^{\mathrm{TM}}$ were measured using the NOx sensor, Pierburg CLD, and a Cambustion CLD. Referring to Equation 3.4, a NOx concentration at the inlet (upstream) and outlet (downstream) of the $\mathrm{dCSC}{ }^{\mathrm{TM}}$ is needed to compute the NOx stored. In this case there are two NOx concentration measurements made at the inlet (upstream) and three NOx concentration measurements made at the outlet (downstream). The upstream $\mathrm{dCSC}^{\mathrm{TM}} \mathrm{NOx}$ concentration is constant throughout Phases III and IV of each of the tests as the engine condition remains constant. The NOx sensor monitors the upstream dCSCTM NOx concentration for the

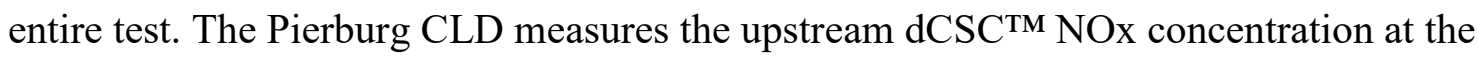
conclusion of Phase IV of each of the tests.

The two upstream dCSCTM NOx concentrations (Pierburg and NOx Sensor) are compared in Figure 4.2. Figure 4.2 includes upstream dCSC ${ }^{\text {TM }}$ NOx concentration data for all of the tests completed. Therefore, tests completed at all three engine conditions described in Chapter 3. The y-axis of the plot is NOx in ppm and the $\mathrm{x}$-axis is the order in which each test was run. The upstream NOx concentration changes slightly from test to test due to factors such as test cell environmental conditions and engine condition. The Pierburg CLD measurement in Figure 4.2 is consistently slightly higher than the NOx sensor measurement. The Pierburg CLD upstream $\mathrm{dCSC}^{\mathrm{TM}}$ NOx concentration measurement is

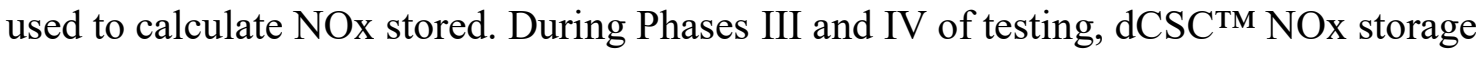
and release are calculated, respectively. 


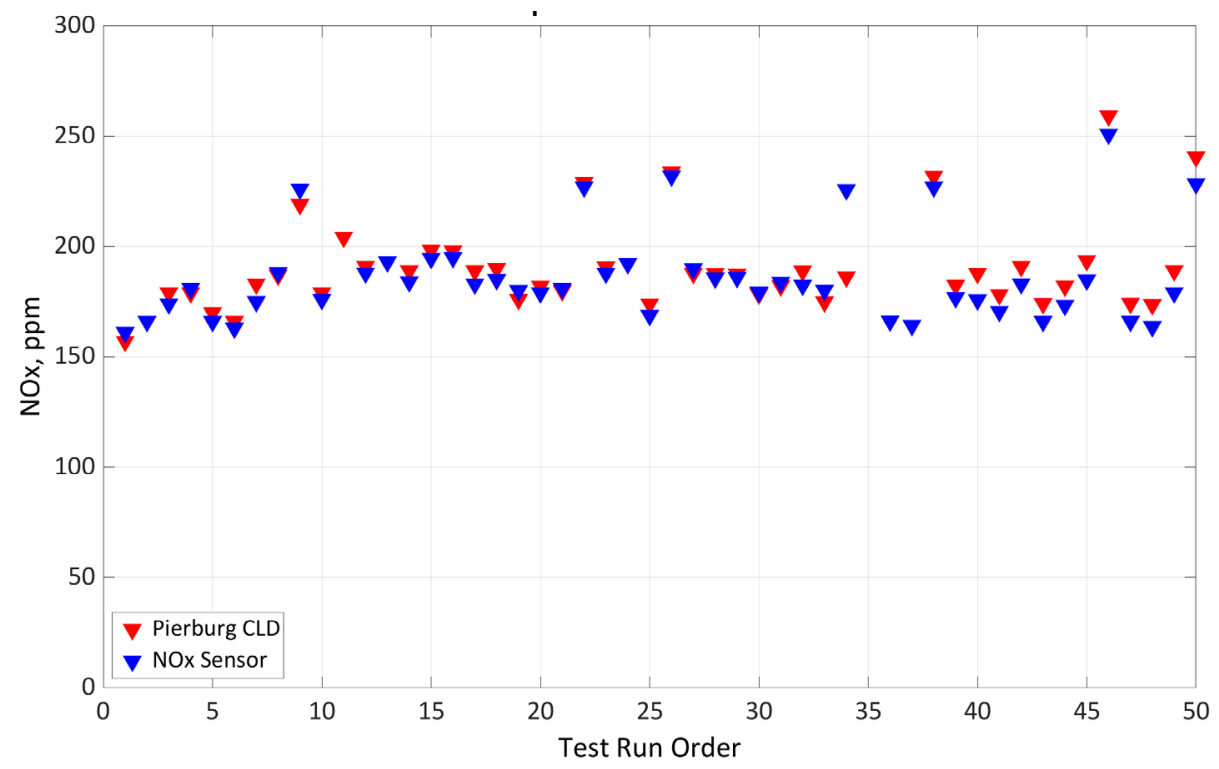

Figure 4.2 Upstream dCSC ${ }^{\mathrm{TM}}$ NOx Concentrations vs. Test Order

In order to calculate $\mathrm{dCSC}^{\mathrm{TM}} \mathrm{NOx}$ storage and release, a downstream dCSC ${ }^{\text {TM }}$ NOx concentration measurement is needed. Figure 4.3 shows the downstream dCSC ${ }^{\text {TM }}$ NOx concentrations from the three different instruments during Phase III and IV of an experiment.

Before the start of Phase III, the $\mathrm{dCSC}^{\mathrm{TM}}$ temperature is controlled to $115^{\circ} \mathrm{C}$ with a feed of room air that has been heated by the $25-\mathrm{kW}$ Watlow heater. Once the dCSCTM temperature is stabilized at $115^{\circ} \mathrm{C}$, the feed is changed from heated ambient air to heated exhaust gas containing approximately $200 \mathrm{ppm}$ of NOx. The exhaust gas temperature is also controlled by the $25-\mathrm{kW}$ Watlow heater. The downstream dCSC ${ }^{\mathrm{TM}} \mathrm{NOx}$ concentration starts at $0 \mathrm{ppm}$ and increases to reach the upstream $\mathrm{dCSC}^{\mathrm{TM}} \mathrm{NOx}$ concentration. The measured concentration of each of the three instruments measuring downstream dCSC ${ }^{\mathrm{TM}} \mathrm{NOx}$ concentrations varies from instrument to instrument. The Pierburg NOx measurement increases first followed by the Cambustion CLD and NOx Sensor, respectively. Therefore, computing NOx stored with each of the three downstream NOx concentrations yields three different NOx stored values. 
During Phase IV, the feed of exhaust gas is being heated from 115 to $300{ }^{\circ} \mathrm{C}$. An increase in downstream dCSC ${ }^{\mathrm{TM}} \mathrm{NOx}$ concentrations is not observed until the exhaust gas temperature reaches $200{ }^{\circ} \mathrm{C}$. By the time the exhaust gas reaches $265^{\circ} \mathrm{C}$, the downstream $\mathrm{dCSC}^{\mathrm{TM}} \mathrm{NOx}$ concentrations have peaked and are decreasing to reach the upstream $\mathrm{dCSC}^{\mathrm{TM}}$ NOx concentration. Therefore, the majority of the NOx release occurs from 200 to $265{ }^{\circ} \mathrm{C}$.

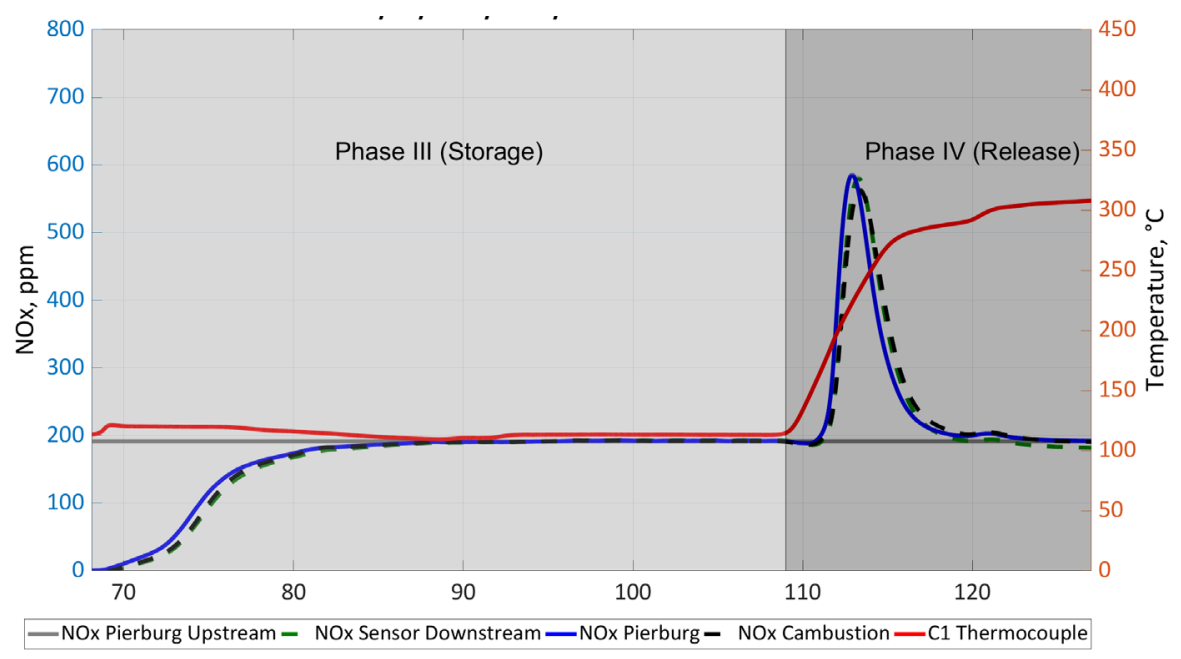

Figure 4.3 Downstream dCSC ${ }^{\mathrm{TM}}$ NOx Concentrations vs. Time during a $115^{\circ} \mathrm{C}$ Phase III and $300{ }^{\circ} \mathrm{C}$ Phase IV, at Engine Condition 1

NOx storage was computed for each of the three NOx concentration measurements downstream of the dCSC ${ }^{\text {TM }}$. Figure 4.4 shows total NOx storage for the tests with a 200 ${ }^{\circ} \mathrm{C}$ temperature during $\mathrm{dCSC}{ }^{\mathrm{TM}}$ test Phase III from each downstream NOx measurement. Note that there is space between the points on the figure because these tests were not conducted with a $200{ }^{\circ} \mathrm{C}$ Phase III storage temperature.

The total NOx stored for the first eight control tests is approximately 0.6 g.NOx/L.Sub. During the last six control tests the total NOx stored was reduced to approximately 0.35 g.NOx/L.Sub. This is likely due to a decrease in the number of active NO storage sites on the $\mathrm{dCSC}^{\mathrm{TM}}$ substrate, or in the effectiveness of the sites, as more tests are completed. 
Engine out NOx is composed of 90 to $95 \% \mathrm{NO}$, only a 5 to $10 \%$ of the $\mathrm{NOx}$ is $\mathrm{NO}_{2}$. Therefore, most of the NOx stored by the $\mathrm{dCSC}^{\mathrm{TM}}$ is NO. The activity of the NO storage sites directly affects the total $\mathrm{NOx}$ storage. However, it is still possible for some $\mathrm{NO}_{2}$ to be stored on the $\mathrm{dCSC} \mathrm{CM}^{\mathrm{TM}}$.

From reference [19], $\mathrm{H}_{2} \mathrm{O}$ can greatly inhibit NOx storage. Ambient air flows through the $\mathrm{dCSC}^{\mathrm{TM}}$ during Phase II of testing to control the $\mathrm{dCSC}^{\mathrm{TM}}$ to the Phase III temperature setpoint. It was investigated as to whether or not the relative humidity in the test cell had an effect on the NOx storage. During the first control test the relative humidity in the test cell was measured to be $36 \%$ and during the last test it was measured to be $28 \%$. From the first control test to the last control test total NOx stored decreased by $46 \%$. The relative humidity during the last test was $8 \%$ lower than it was during the first test. This indicates that relative humidity of the test cell did not affect the total NOx storage. There was no trend showing that relative humidity in the test cell increased as NOx stored decreased. The relative humidity in the test cell was recorded for each test (Appendix G, Figure G.12) and the engine out $\mathrm{H}_{2} \mathrm{O}$ concentrations are shown in Table 3.4.

There are significant reductions in control test total NOx storage from approximately 0.6 to 0.5 g.NOx/L.Sub. and 0.5 to 0.4 g.NOx/L.Sub. at the $15^{\text {th }}$ test and the $35^{\text {th }}$ test, respectively. These two transitions occur from control test 7 to 8 and control test 17 to 18 and have been labeled with a black dashed line in Figure 4.4. The time the dCSC ${ }^{\mathrm{TM}}$ was at $500{ }^{\circ} \mathrm{C}$ and exposed to engine exhaust while the engine was at $1660 \mathrm{rpm}$ and $600 \mathrm{~N}-\mathrm{m}$ was quantified at the start of the $15^{\text {th }}$ and $35^{\text {th }}$ tests. At the start of the $15^{\text {th }}$ test the $\mathrm{dCSC}^{\text {TM }}$ had been at $500{ }^{\circ} \mathrm{C}$ and exposed to exhaust gas from the diesel engine at 1660 $\mathrm{rpm}$ and $600 \mathrm{~N}-\mathrm{m}$ for a total of 5 hours and 30 minutes. At the start of the $35^{\text {th }}$ test the $\mathrm{dCSC}^{\mathrm{TM}}$ had been exposed to these conditions for 9 hours and 10 minutes. This hightemperature high load exposure is likely the reason for the reduced activity of the NO storage sites. 


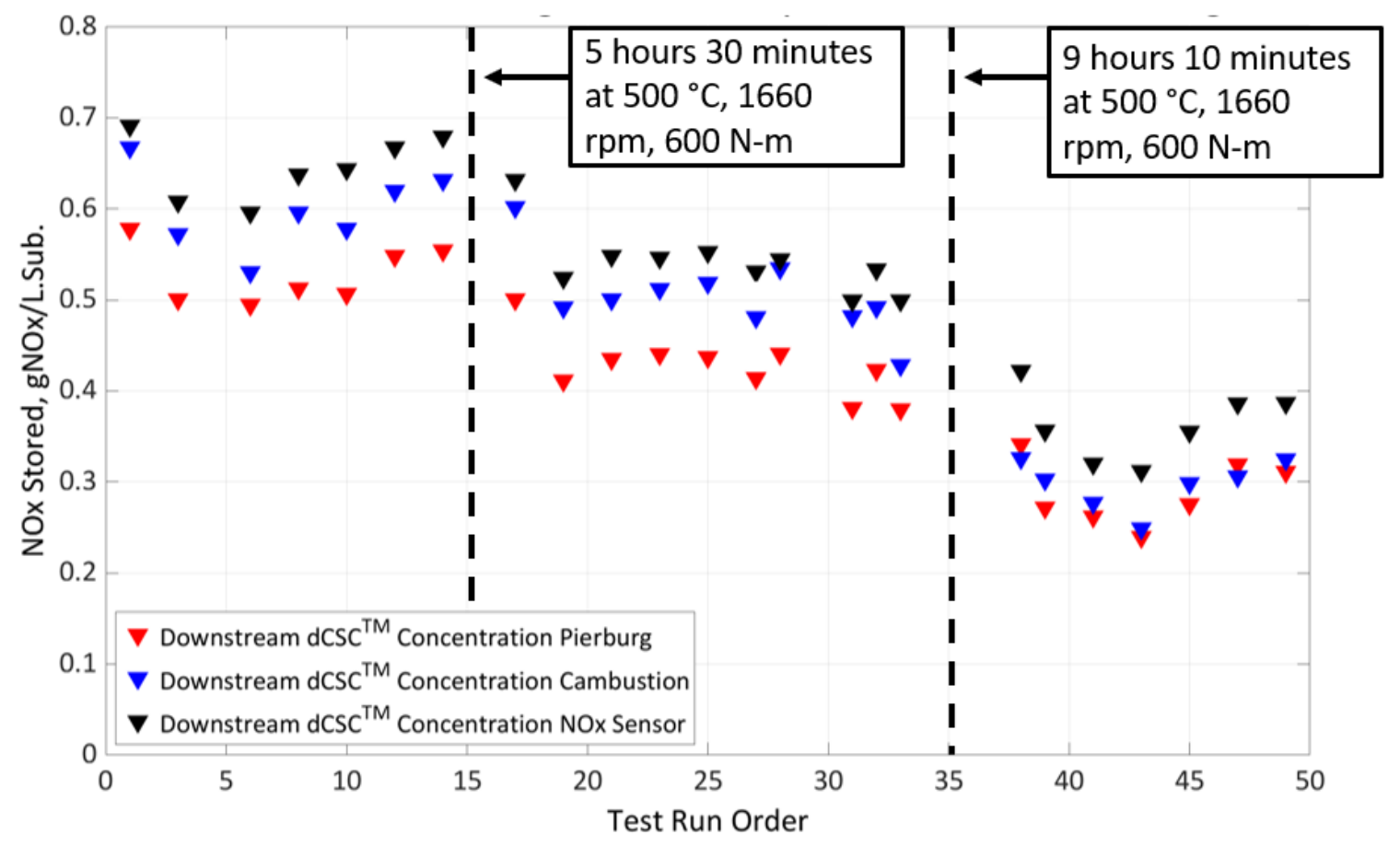

Figure 4.4 Control Test $200^{\circ} \mathrm{C}$ Phase III dCSC ${ }^{\mathrm{TM}}$ Total NOx Stored vs. Test Order

Figure 4.5 shows the data from Phase III (storage) from two control tests, control test 7 and control test 23 . Control test 7 was the $14^{\text {th }}$ test to be run and control test 23 was the $48^{\text {th }}$ test run. Figure 4.5 shows downstream dCSC $^{\text {TM }}$ NOx concentrations from the Pierburg CLD, during the $200{ }^{\circ} \mathrm{C}$ Phase III, for both tests. It also shows total NOx stored, computed from the downstream NOx concentrations. The total NOx stored from control test 23 is 0.32 g.NOx/L.Sub. while the total NOx stored from control test 7 is 0.55 g.NOx/L.Sub. This is a significant decrease in the total NOx storage capacity of the $\mathrm{dCSC}^{\text {TM }}$ from the $14^{\text {th }}$ to the $48^{\text {th }}$ test run.

The initial rate of storage appears to be similar from 79-81 minutes, which refers to the initial bulk diffusion of reactants. Bulk diffusion of reactants is when the NO is reacting with the NO storage sites on the outer surfaces of the substrate, which are the easiest storage sites to reach, as discussed in reference [23]. The pore diffusion of reactants is when the NO in the feed gas has to diffuse through the substrate to reach active NO storage sites that are not as accessible as the bulk diffusion storage sites. Reactants go to 
these sites after the easiest (bulk diffusion) NO storage sites have been saturated, as discussed in reference [23]. At a time of 81 minutes, the two NOx traces split and test 23's downstream dCSC ${ }^{\text {TM }}$ NOx concentration increases more rapidly towards the upstream NOx concentration than test 7's. This indicates a decrease in the activity of the pore diffusion $\mathrm{NO}$ storage sites on the $\mathrm{dCSC}^{\mathrm{TM}}$, which causes the decrease in NOx storage capacity.
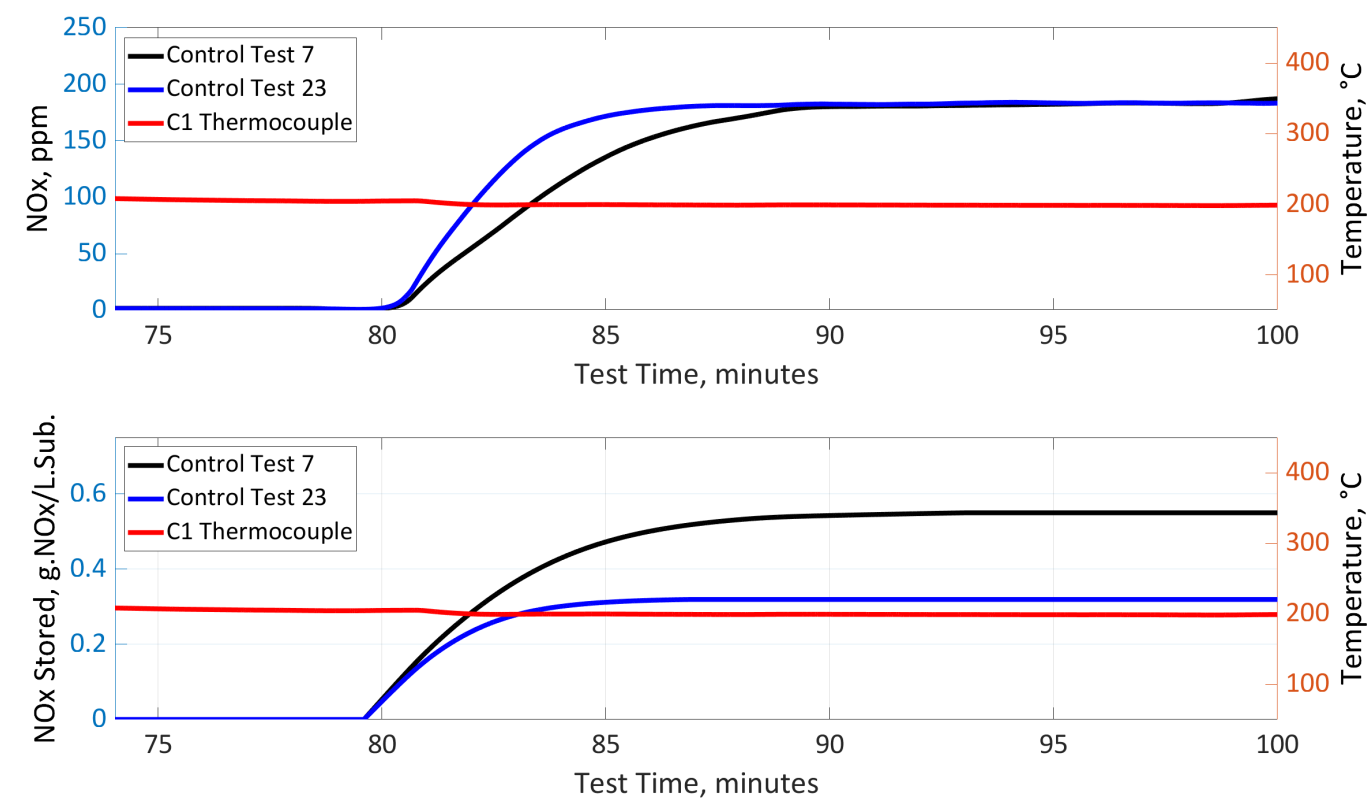

Figure 4.5 Control Test $200{ }^{\circ} \mathrm{C}$ Phase III NOx Storage Comparison, at Engine Condition 1

Over 200 hours of testing was completed on the $\mathrm{dCSC}^{\mathrm{TM}}$. The total NOx storage capacity of the $\mathrm{dCSC}^{\mathrm{TM}}$ appears to decrease over time due to a reduction of the active pore diffusion NO storage sites. However, the bulk diffusion NO storage sites appear to remain active. dCSC ${ }^{\mathrm{TM}}$ NOx storage capacity was computed for the first 200 seconds of each test. Figure 4.6 shows the total NOx stored during the first 200 seconds of the 200 ${ }^{\circ} \mathrm{C}$ Phase III control tests. The 200 -second NOx storage capacity of the dCSCTM over the first 15 tests is roughly 0.35 g.NOx/L.Sub. The 200 -second NOx storage capacity over 
the last 15 tests is slightly less at 0.3 g.NOx/L.Sub. Indicating that the majority of the $\mathrm{dCSC}^{\mathrm{TM}}$ bulk diffusion NO storage sites remain active.

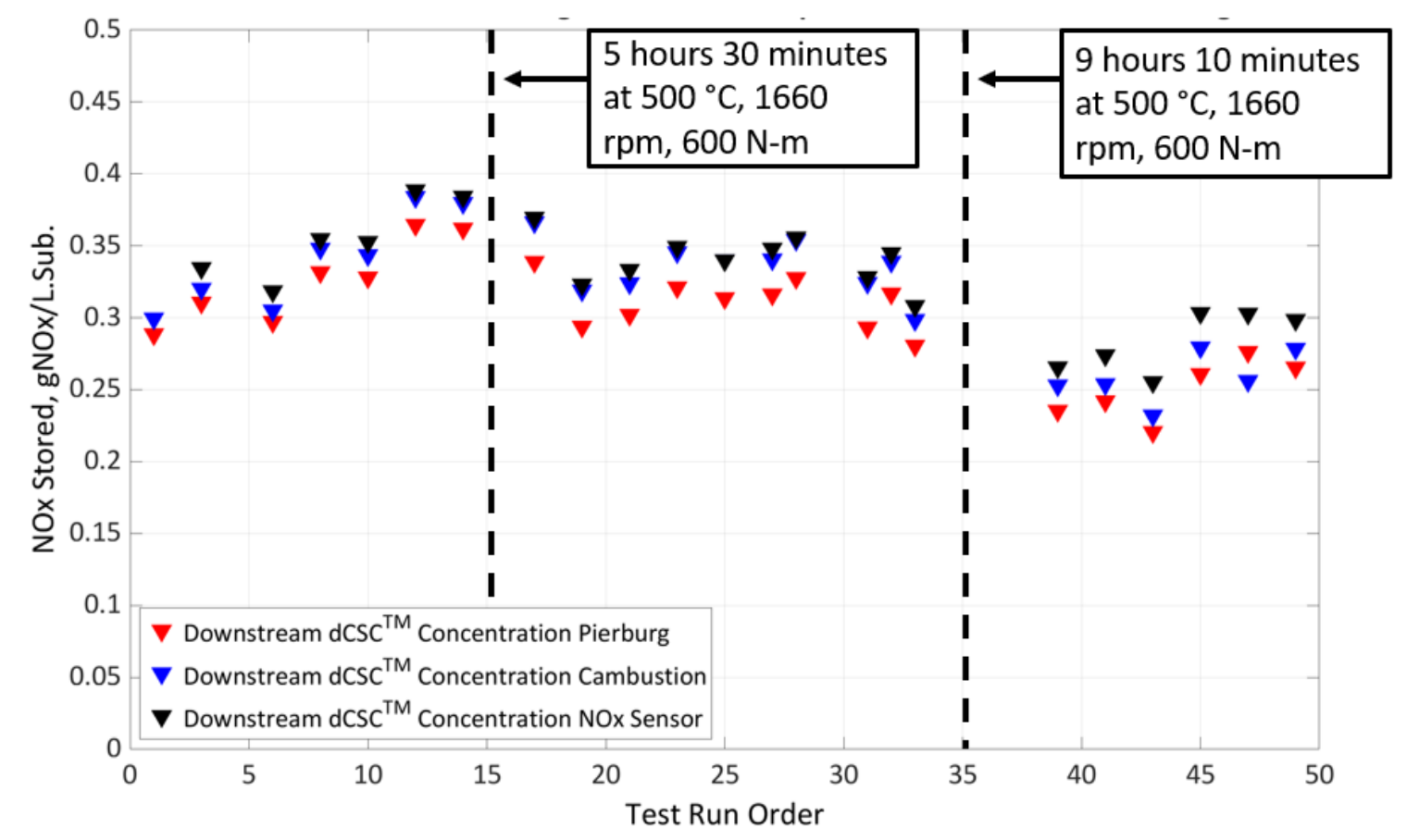

Figure 4.6 Control Test $200{ }^{\circ} \mathrm{C}$ Phase III 200-second dCSCTM NOx Storage Capacity vs. Test Order

The 200-second NOx storage capacity of the $\mathrm{dCSC}^{\mathrm{TM}}$ at Phase III test temperatures of 80 to $250{ }^{\circ} \mathrm{C}$ was computed. The NOx measurements used were the Pierburg CLD, upstream and downstream measurements. Figure 4.7 shows the 200 second NOx storage capacity of the $\mathrm{dCSC}^{\mathrm{TM}}$ versus the average volume weighted temperature calculated by the equations in section 3.4.3.

Consistent with references [1] and [8], the range of temperatures at which the $\mathrm{dCSC} \mathrm{CM}^{\mathrm{TM}}$ stores the largest quantity of NOx is 125 to $150{ }^{\circ} \mathrm{C}$. The storage capacity slightly decreases as the temperature decreases from $125^{\circ} \mathrm{C}$. This is because as the temperature is decreasing, the water concentration in the exhaust is increasing. The higher presence of water in the exhaust inhibits the ability of the NO storage sites on the $\mathrm{dCSC}{ }^{\mathrm{TM}}$, as is 
discussed in references $[1,8,19]$. At temperatures above $200{ }^{\circ} \mathrm{C}$ the NO storage sites on the $\mathrm{dCSC}^{\mathrm{TM}}$ become unstable and less able to store NOx $[1,8]$.

The black curve in Figure 4.7 is a $3^{\text {rd }}$ order polynomial fit of the tests performed at engine condition 1. There are two points in Figure 4.7 at $150{ }^{\circ} \mathrm{C}$ and 0.65 g.NOx/L.Sub. that were performed at engine condition 2 (exhaust flow rate $-4.9 \mathrm{~kg} / \mathrm{min}$ ), where the exhaust flow rate is $1.5 \mathrm{~kg} / \mathrm{min}$ more than engine condition 1 (exhaust flow rate $-3.5 \mathrm{~kg} / \mathrm{min}$ ). Therefore, during the 200 -second period, the $\mathrm{dCSC}{ }^{\mathrm{TM}}$ NO storage sites were exposed to a more molecules of NO than the tests at engine condition 1, and thus store a larger mass of NOx.

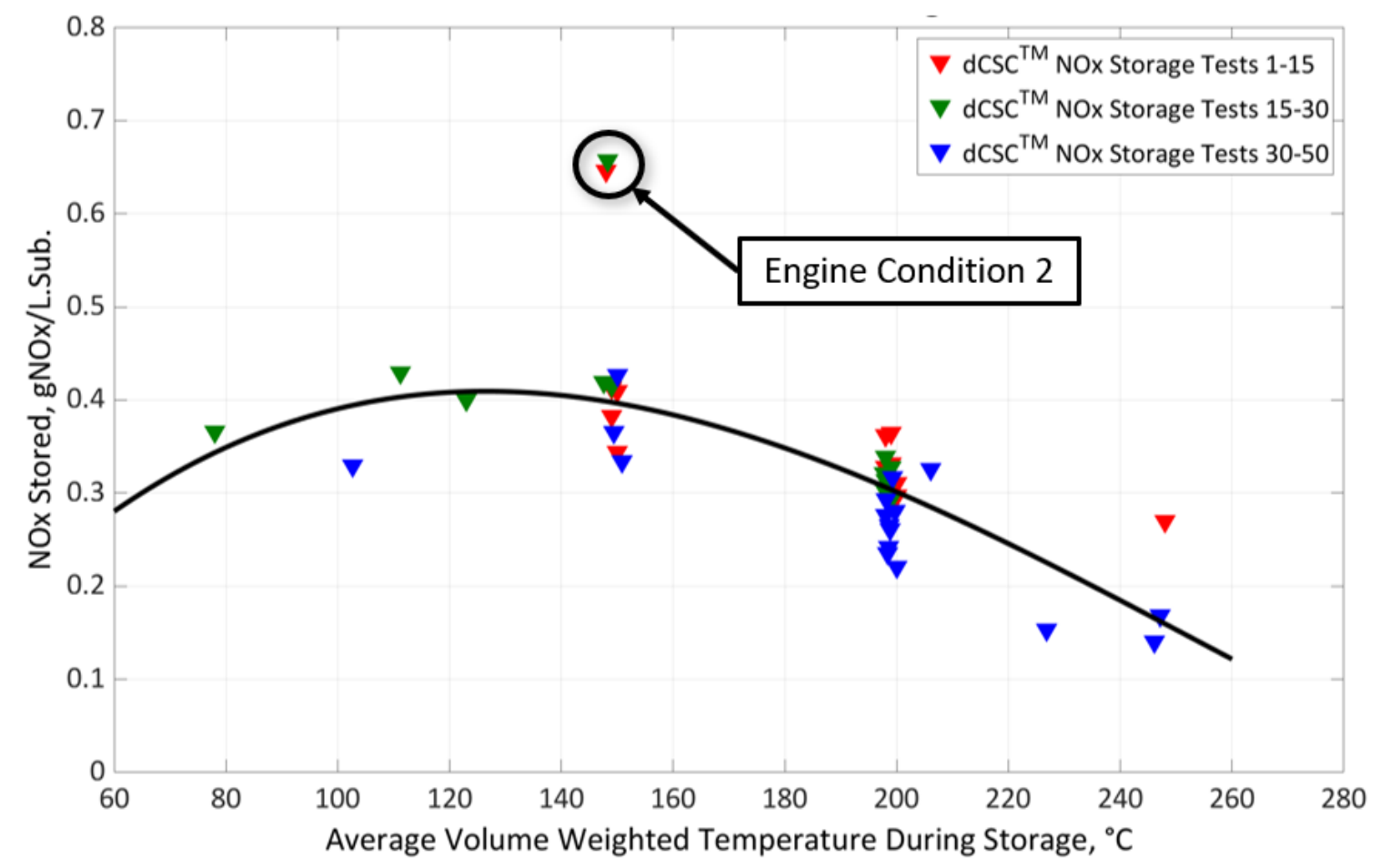

Figure 4.7 200-second dCSC ${ }^{\mathrm{TM}}$ NOx Storage Capacity vs. Temperature at all Engine Conditions

During Phase III of each test, the ratio of downstream dCSCTM NOx concentration to the upstream concentration ( $\mathrm{dCSC}^{\text {TM }} \mathrm{NOx}$ inlet to outlet ratio) begins at 0 and increases to 1 . The time it takes for the ratio to reach 0.5 (dCSC $\mathrm{dM} 50 \%$ NOx storage capacity) is 
dependent upon the temperature of the $\mathrm{dCSC}^{\mathrm{TM}}$. Figure 4.8 shows time in minutes for the ratio to reach 0.5 at different $\mathrm{dCSC} \mathrm{CM}^{\mathrm{TM}}$ temperatures.

The data in Figure 4.8 refers to the tests in three groups, tests 1-15, tests 15-30, and tests 30-50. The groups are arranged in chronological order in which the tests were run. Tests 1-15 show the largest amount of time before the $\mathrm{dCSC}$ TM $50 \%$ NOx storage capacity is reached, while tests 15-30 show a reduction in time and tests 30-50 show an even further reduction in time. The reduction in time to the $50 \%$ NOx storage capacity with increasing number of tests run is another indication that the pore diffusion NO storage sites are becoming less active.

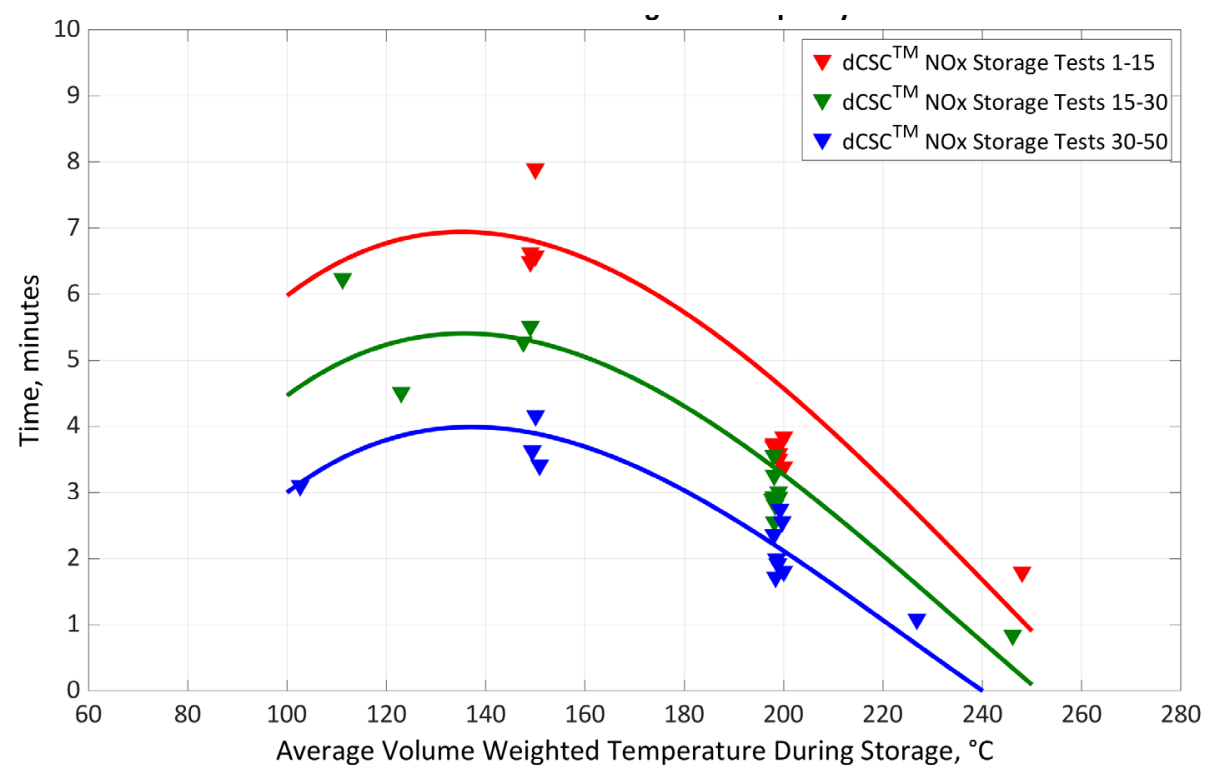

Figure $4.850 \%$ dCSC ${ }^{\mathrm{TM}}$ NOx Storage Capacity vs. Temperature

\subsection{NO, $\mathrm{NO}_{2}$, and NOx Release Performance}

NOx release is calculated during Phase IV of each test. During this phase, the $\mathrm{dCSC}^{\mathrm{TM}}$ temperature increases from the temperature setpoint during Phase III to the temperature setpoint for Phase IV. As the $\mathrm{dCSC}^{\mathrm{TM}}$ temperature increases, the downstream $\mathrm{dCSC}^{\mathrm{TM}}$ NOx concentration increases from the initial value to a peak and then decreases to the 
initial value, which indicates a NOx release. The NOx released in g.NOx/L.Sub. is calculated during this time using Equation 3.4.

Figure 4.9 shows the NOx released by the $\mathrm{dCSC}^{\mathrm{TM}}$ at different Phase IV (release) average volume weighted temperatures. The average volume weighted temperature of the $\mathrm{dCSC}^{\mathrm{TM}}$ is calculated using the equations in section 3.4.3. The $\mathrm{dCSC}^{\mathrm{TM}} \mathrm{NOx}$ storage capacity is highest at Phase III (storage) temperatures of 125 to $150{ }^{\circ} \mathrm{C}$ and decreases as temperature increases from that range. Tests run with Phase III temperatures of 200 to $250{ }^{\circ} \mathrm{C}$ showed lower total NOx storage capacity. The dCSC ${ }^{\text {TM }}$ can only release NOx that it has first adsorbed or stored. Therefore, the NOx released is dependent upon the NOx stored during Phase III, which is dependent upon the Phase III dCSCTM temperature. In addition, $\mathrm{dCSC}^{\mathrm{TM}} \mathrm{NOx}$ storage capacity has shown to decrease with increasing number of tests run.

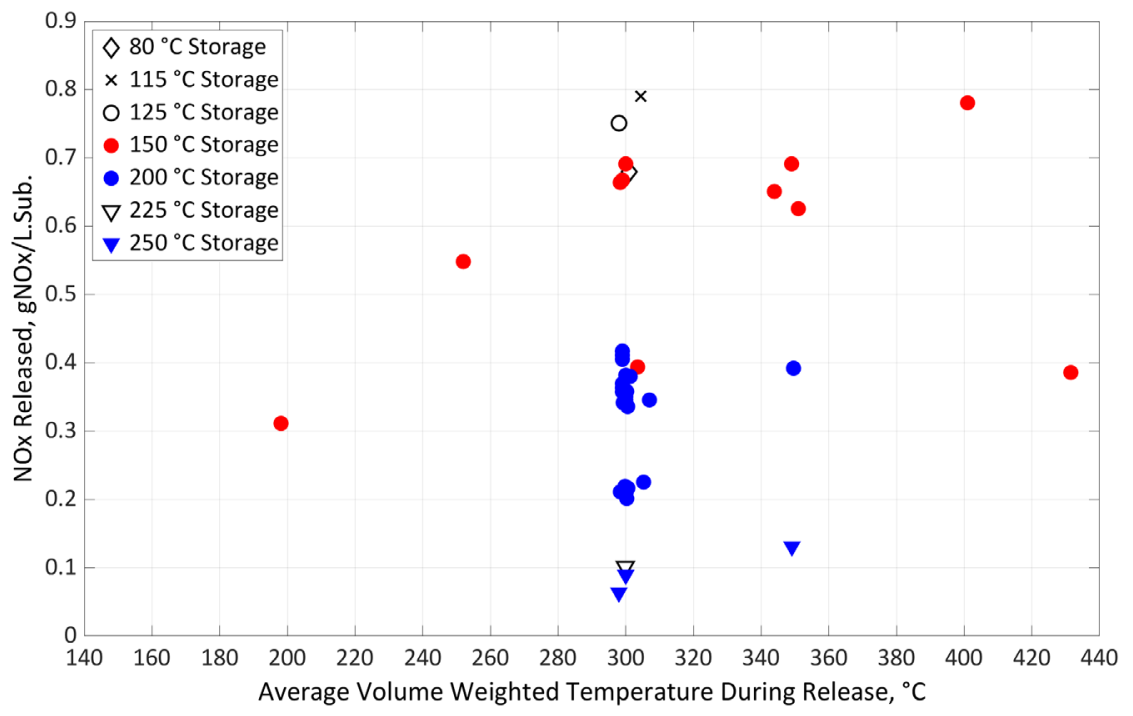

Figure 4.9 dCSC ${ }^{\text {TM }}$ Total NOx Released vs. Temperature

The tests with $150{ }^{\circ} \mathrm{C}$ Phase III storage temperatures were followed by Phase IV release temperatures of 200 to $450^{\circ} \mathrm{C}$. This was done to determine the percentage of NOx stored that is released at different temperatures. Figure 4.10 shows the percentage of NOx stored during Phase III that is released during Phase IV. The black line is a curve fit through the percentage of stored NOx released points during the tests with a $150{ }^{\circ} \mathrm{C}$ Phase III 
(storage) temperature. With a $150{ }^{\circ} \mathrm{C}$ Phase III temperature, as Phase IV (release) temperature increases, the percentage of NOx stored released also increases.

Two of the tests with a $300{ }^{\circ} \mathrm{C}$ average volume weighted release temperature, show a percentage of stored NOx released lower than $30 \%$. These two tests had a storage temperature of $250{ }^{\circ} \mathrm{C}$. Therefore, the temperature increase during Phase IV was from 250 to $300{ }^{\circ} \mathrm{C}$. The rapid NOx release of the $\mathrm{dCSC}^{\text {TM }}$ has been found to occur from 200 to $265{ }^{\circ} \mathrm{C}$ in reference [8]. Therefore, the NOx release event for these two tests, which occurs from 250 to $300{ }^{\circ} \mathrm{C}$, does not pass through the rapid NOx release temperature range. However, there is a secondary rapid NOx release centered around $350{ }^{\circ} \mathrm{C}$ per reference [8]. A test was conducted with $250{ }^{\circ} \mathrm{C}$ Phase III storage temperature and a 350 ${ }^{\circ} \mathrm{C}$ Phase IV release temperature that shows over $90 \%$ of the stored NOx released. Therefore, in order to release a high percentage of the stored NOx, the release temperature ramp must ramp from $200-265^{\circ} \mathrm{C}$ or reach at least $350{ }^{\circ} \mathrm{C}$. The 250 to 350 ${ }^{\circ} \mathrm{C}$ temperature ramp is $60 \%$ more efficient at releasing NOx than the 250 to $300{ }^{\circ} \mathrm{C}$ temperature ramp.

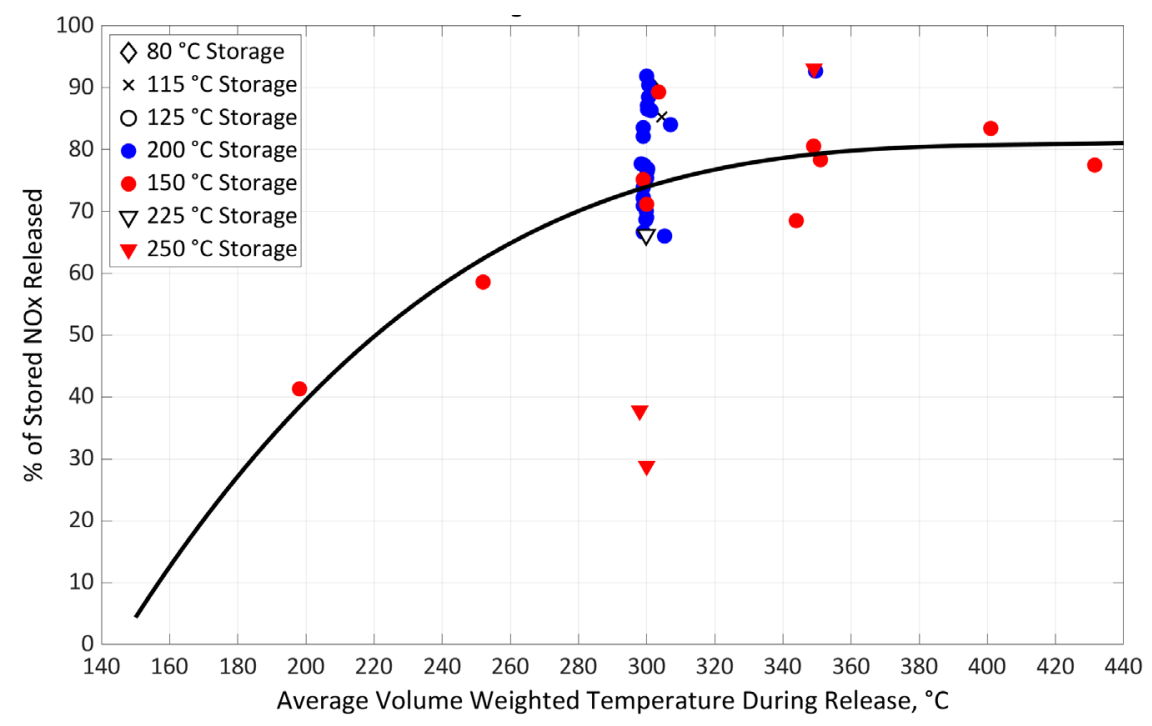

Figure $4.10 \mathrm{dCSC}^{\text {TM }}$ Percent of Stored NOx Released vs. Temperature 


\subsection{NO to $\mathrm{NO}_{2}$ Oxidation Characteristics}

The dCSC ${ }^{\mathrm{TM}}$ oxidizes $\mathrm{NO}$ to $\mathrm{NO}_{2}$ through the catalytic oxidation reaction show in Equation 4.1 below.

$$
2 \mathrm{NO}+\mathrm{O}_{2} \leftrightarrow 2 \mathrm{NO}_{2}
$$

During Phases III and IV of testing, after the transient NOx storage and release periods, steady state emissions are measured. The Cambustion CLD measures NO and NOx downstream of the dCSCTM. Subtracting the NO from the NOx measurement yields $\mathrm{NO}_{2}$. This $\mathrm{NO}_{2}$ value and the Cambustion $\mathrm{NOx}$ value are used to calculate the $\mathrm{NO}_{2}$ to $\mathrm{NOx}$ ratio at the $\mathrm{dCSC}^{\mathrm{TM}}$ outlet.

Figure 4.11 shows the $\mathrm{NO}$ to $\mathrm{NO}_{2}$ oxidation performance of the $\mathrm{dCSC} \mathrm{CM}^{\mathrm{TM}}$ at different temperatures. As temperature increases, the $\mathrm{NO}$ to $\mathrm{NO}_{2}$ oxidation reaction rate increases and more of the NO passing through the substrate is oxidized to $\mathrm{NO}_{2}$. Therefore, as the $\mathrm{dCSC}^{\mathrm{TM}}$ temperature increases from 100 to $300^{\circ} \mathrm{C}$, the $\mathrm{NO}_{2} / \mathrm{NOx}$ ratio increases. Which indicates that the $\mathrm{NO}$ to $\mathrm{NO}_{2}$ oxidation is increasing. At temperatures below $300{ }^{\circ} \mathrm{C}$ Equation 4.1 has an equilibrium towards the right side of the equation. From 300 to $450^{\circ} \mathrm{C}$, the $\mathrm{NO}_{2} / \mathrm{NOx}$ ratio decreases, meaning less of the $\mathrm{NO}$ passing through the substrate at these temperatures is oxidized to $\mathrm{NO}_{2}$. This is because Equation 4.1 has an equilibrium which shifts to the left side of the equation at these higher temperatures which is discussed in reference [27]. Therefore, the $\mathrm{dCSC}{ }^{\mathrm{TM}} \mathrm{NO}$ to $\mathrm{NO}_{2}$ ratio is decreasing as temperature increases beyond $300{ }^{\circ} \mathrm{C}$. 


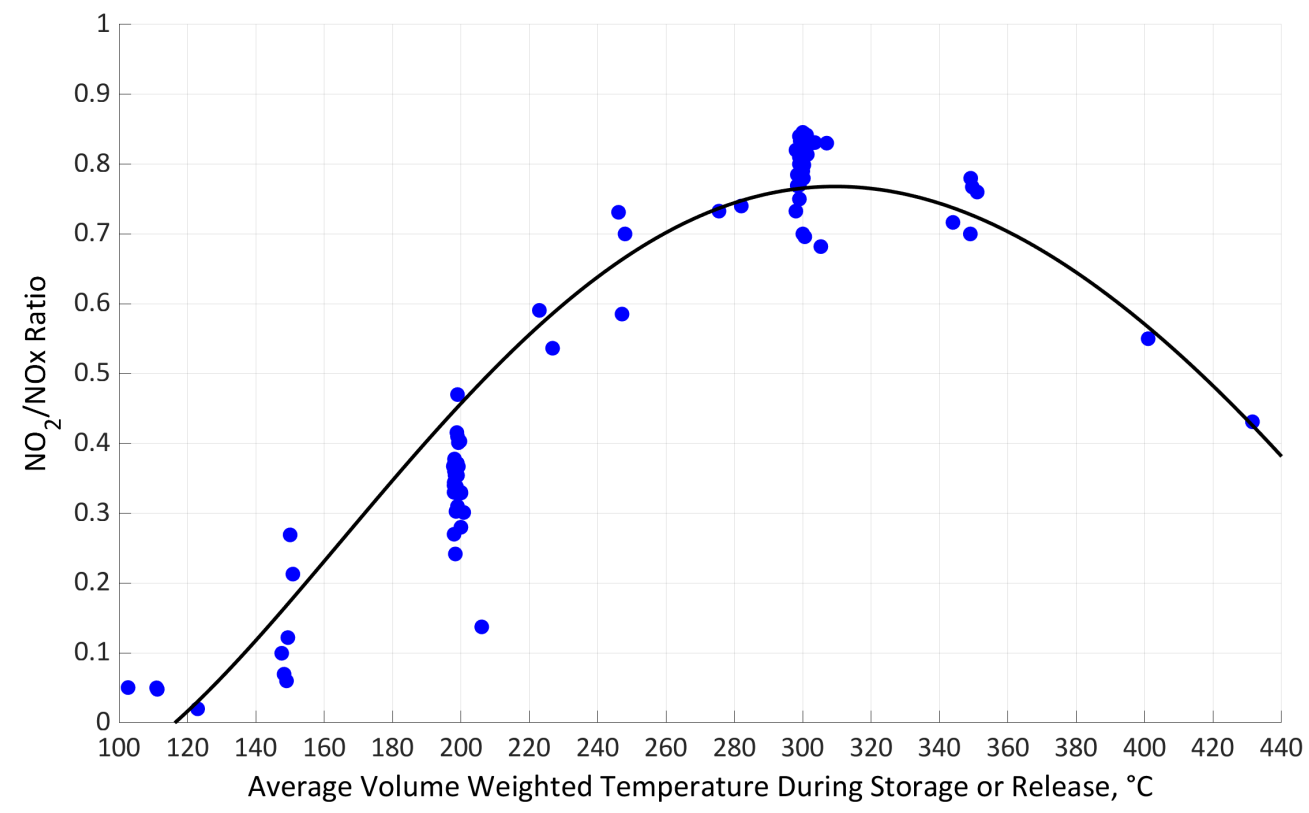

Figure 4.11 Downstream dCSC ${ }^{\text {TM }} \mathrm{NO}_{2} / \mathrm{NOx}$ Ratio vs. Temperature

\section{5 $\quad \mathrm{N}_{2} \mathrm{O}$ Production}

$\mathrm{N}_{2} \mathrm{O}$ concentrations were measured downstream of the $\mathrm{dCSC}^{\mathrm{TM}}$ substrate during Phases III and IV of testing. While the dCSC ${ }^{\text {TM }}$ is releasing NOx, after a Phase III storage temperature of $150{ }^{\circ} \mathrm{C}$ or less, there is a low level of $\mathrm{NOx}$ conversion to $\mathrm{N}_{2} \mathrm{O}$ observed. This production of $\mathrm{N}_{2} \mathrm{O}$ in the $\mathrm{dCSC}^{\mathrm{TM}}$ is a result of the $\mathrm{HC}$ lean NOx reduction that occurs on the substrate, as discussed in reference [1]. The oxidation of adsorbed HC and $\mathrm{NO}$, once the $\mathrm{dCSC} \mathrm{TM}^{\mathrm{TM}}$ is approximately $200{ }^{\circ} \mathrm{C}$ and above, potentially results in the formation of $\mathrm{N}_{2} \mathrm{O}$ [28]. Equation $\mathrm{H} .1$ and H.2 in Appendix $\mathrm{H}$ describes the reactions that produce $\mathrm{N}_{2} \mathrm{O}$ [28].

Figure 4.12 shows the $\mathrm{N}_{2} \mathrm{O}$ concentration at the $\mathrm{dCSC}^{\mathrm{TM}}$ outlet during an $80{ }^{\circ} \mathrm{C}$ Phase III and a $300{ }^{\circ} \mathrm{C}$ Phase IV, at engine condition 3. At the beginning Phase IV, while the $\mathrm{dCSC}^{\mathrm{TM}}$ is releasing $\mathrm{NOx}$ and $\mathrm{HC}$, there is $\mathrm{N}_{2} \mathrm{O}$ production. The $\mathrm{N}_{2} \mathrm{O}$ concentration increases to a peak of $12 \mathrm{ppm}$ and then decreases to a constant concentration of $0 \mathrm{ppm}$ at the $300{ }^{\circ} \mathrm{C}$ Phase IV temperature. 


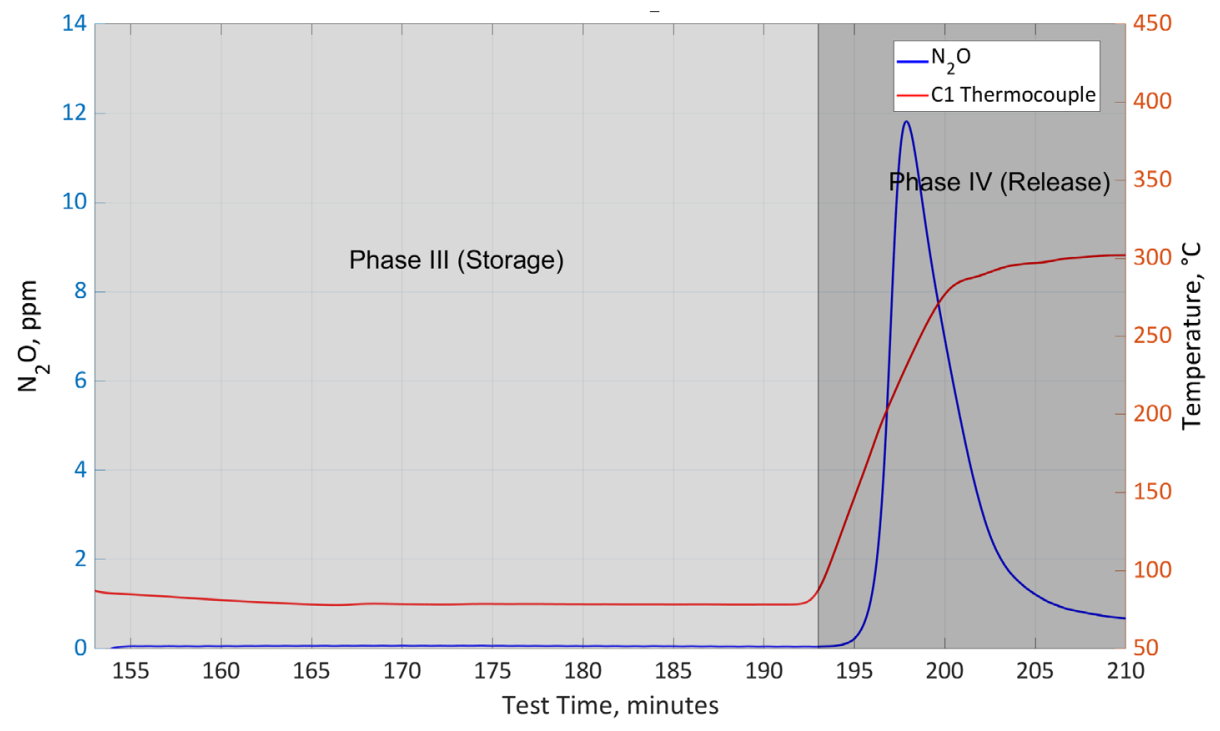

Figure 4.12 $\mathrm{N}_{2} \mathrm{O}$ Concentration vs. Time during an $80{ }^{\circ} \mathrm{C}$ Phase III and a $300{ }^{\circ} \mathrm{C}$ Phase IV, at Engine Condition 3

\subsection{CO Storage/Oxidation Performance}

Figure 4.13 shows the $\mathrm{CO}$ concentration at the $\mathrm{dCSC}^{\mathrm{TM}}$ outlet, during a $125^{\circ} \mathrm{C}$ Phase III and $300{ }^{\circ} \mathrm{C}$ Phase IV test at engine condition 1. During Phase III the downstream $\mathrm{dCSC}^{\text {TM }} \mathrm{CO}$ concentration increases from $0 \mathrm{ppm}$ to a constant value of $35 \mathrm{ppm}$. The $\mathrm{CO}$ concentration upstream during this test is $85 \mathrm{ppm}$. The difference between the upstream 85 ppm CO concentration and downstream 35 ppm CO concentration is stored/oxidized by the $\mathrm{dCSC}^{\text {TM }}$. During the start of Phase IV, as the $\mathrm{dCSC}^{\text {TM }}$ temperature is increasing from 125 to $300{ }^{\circ} \mathrm{C}$, the $\mathrm{CO}$ concentration decreases to $0 \mathrm{ppm}$. As the $\mathrm{dCSC} \mathrm{TM}^{\mathrm{TM}}$ temperature increases, the $\mathrm{CO}$ oxidation capability of the $\mathrm{dCSC} \mathrm{TM}^{\mathrm{TM}}$ increases and oxidizes all the $\mathrm{CO}$ to $\mathrm{CO}_{2}$. 


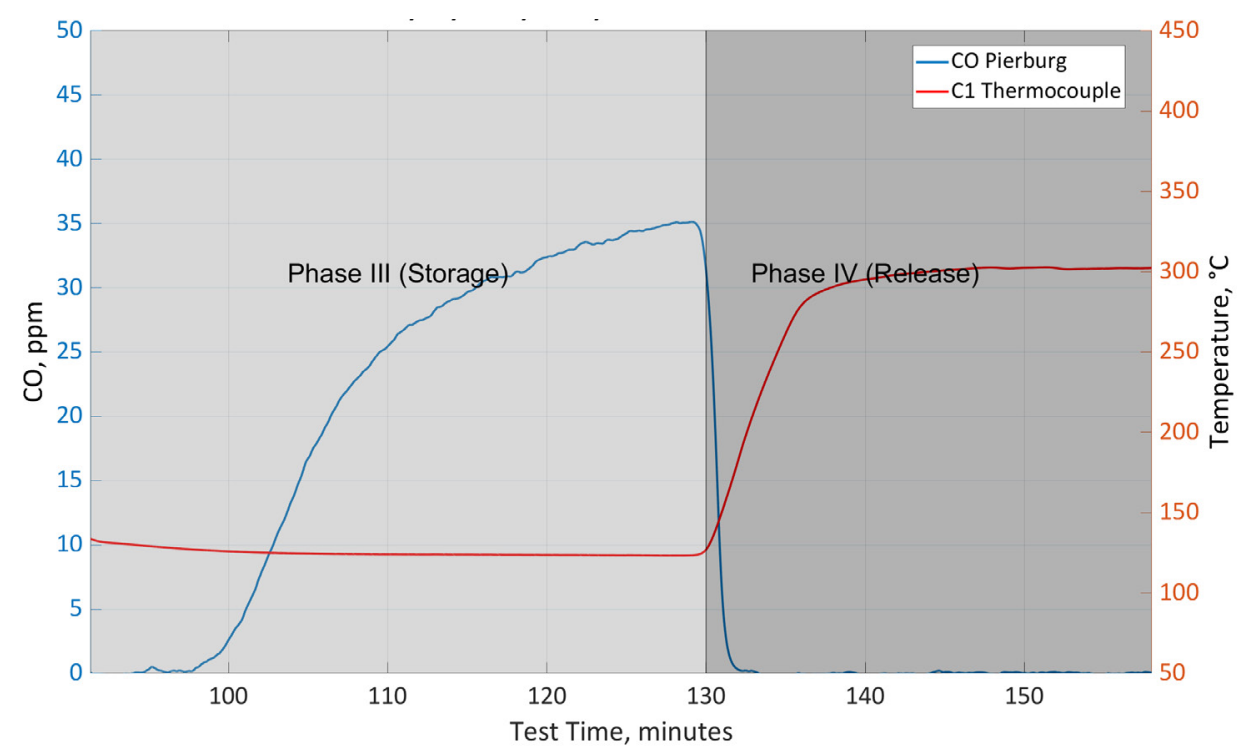

Figure 4.13 Downstream dCSC ${ }^{\text {TM }} \mathrm{CO}$ vs. Time during a $125^{\circ} \mathrm{C}$ Phase III and $300{ }^{\circ} \mathrm{C}$ Phase IV, at Engine Condition 3

Figure 4.14 shows the $\mathrm{dCSC}{ }^{\mathrm{TM}} \mathrm{CO}$ storage/oxidation efficiency of the $125^{\circ} \mathrm{C}$ Phase III and $300{ }^{\circ} \mathrm{C}$ Phase IV test, . During Phase III, the storage/oxidation efficiency starts at $100 \%$ and then decreases to $55 \%$ towards the end of Phase III. At the start of Phase IV the $\mathrm{dCSC} \mathrm{TM}^{\mathrm{TM}}$ temperature increase from 125 to $300^{\circ} \mathrm{C}$. As dCSC $\mathrm{AM}^{\mathrm{TM}}$ temperature increases the CO storage/oxidation increases to $100 \%$. As $\mathrm{dCSC}^{\mathrm{TM}}$ temperature increases all of the upstream $\mathrm{CO}$ is oxidized to downstream $\mathrm{CO}_{2}$. 


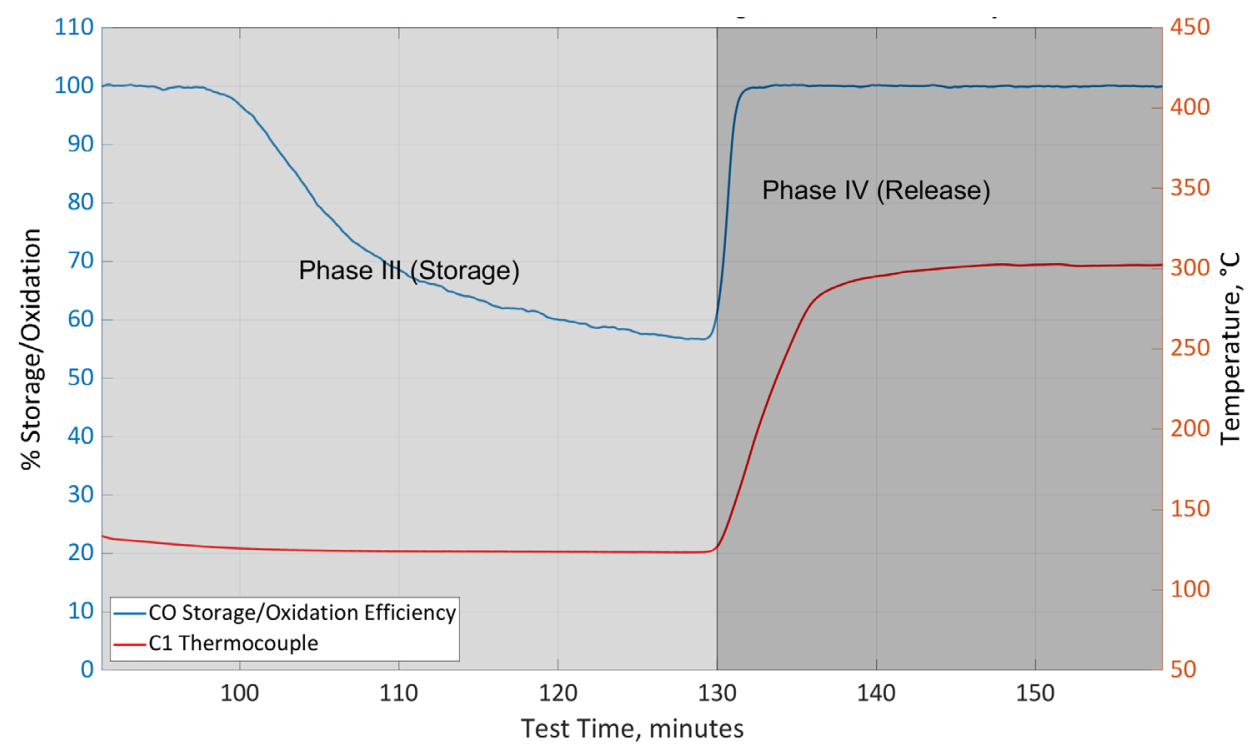

Figure 4.14 dCSC ${ }^{\text {TM }}$ CO Storage/Oxidation Efficiency vs. Time during a $125{ }^{\circ} \mathrm{C}$ Phase III and $300{ }^{\circ} \mathrm{C}$ Phase IV, at Engine Condition 1

Figure 4.15 shows the steady state $\mathrm{CO}$ oxidation of the $\mathrm{dCSC} \mathrm{CM}^{\mathrm{TM}}$ at different average volume weighted temperatures during Phases III and IV. The data in Figure 4.15 are from all the testing completed. At $150{ }^{\circ} \mathrm{C}$, there is $100 \% \mathrm{CO}$ oxidation for the tests completed at engine condition 1 . The $150{ }^{\circ} \mathrm{C}$ tests at engine condition 2 showed $90-99 \% \mathrm{CO}$ oxidation. This is because at engine condition 2 (exhaust flow rate $-4.9 \mathrm{~kg} / \mathrm{min}$ ), the exhaust flow rate is $1.5 \mathrm{~kg} / \mathrm{min}$ more than engine condition 1 (exhaust flow rate -3.5 $\mathrm{kg} / \mathrm{min}$ ). Therefore, the $\mathrm{dCSC} \mathrm{CM}^{\mathbf{T}}$ is exposed to more molecules of $\mathrm{CO}$ at engine condition 2 than at engine condition 1 . At temperatures above $150{ }^{\circ} \mathrm{C}$ the $\mathrm{dCSC} \mathrm{CM}^{\mathrm{TM}} \mathrm{CO}$ oxidation is $100 \%$. The $\mathrm{CO}$ oxidation $\%$ decreases from 150 to $100{ }^{\circ} \mathrm{C}$ because the $\mathrm{CO}$ to $\mathrm{CO}_{2}$ oxidation reaction rate is decreasing as temperature decreases. Also, the $\mathrm{CO}$ storage ability of the $\mathrm{dCSC}^{\mathrm{TM}}$ is being inhibited by $\mathrm{H}_{2} \mathrm{O}$ in the exhaust at these low temperatures. However, from 100 to $80{ }^{\circ} \mathrm{C}$ the $\mathrm{CO}$ oxidation percentage increases. This is because the test at $80{ }^{\circ} \mathrm{C}$ was performed at engine condition 3 (exhaust flow rate $-2.6 \mathrm{~kg} / \mathrm{min}$ ) where the exhaust flow rate is $0.9 \mathrm{~kg} / \mathrm{min}$ less than engine condition 1 (exhaust flow rate -3.5 $\mathrm{kg} / \mathrm{min}$ ) where the $100{ }^{\circ} \mathrm{C}$ test was completed. Therefore, the $\mathrm{dCSC} \mathrm{CM}^{\mathrm{TM}}$ is exposed to fewer molecules of $\mathrm{CO}$ at engine condition 3 than at engine condition 1. At temperatures 
from 80 to $125{ }^{\circ} \mathrm{C}$ the $\mathrm{dCSC}^{\mathrm{TM}}$ showed 55 to $70 \% \mathrm{CO}$ oxidation and 90 to $100 \% \mathrm{CO}$ oxidation at temperatures from 150 to $400{ }^{\circ} \mathrm{C}$.

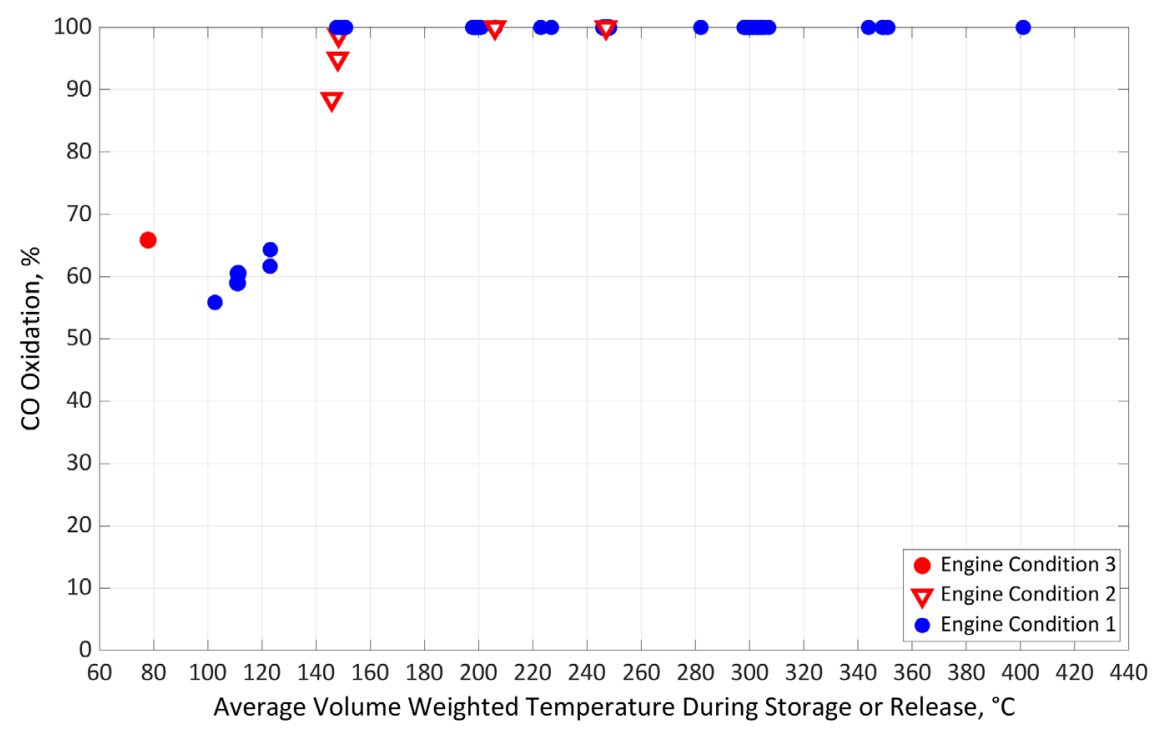

Figure 4.15 Downstream dCSC ${ }^{\mathrm{TM}} \mathrm{CO}$ Oxidation \% vs. Temperature

\subsection{D Temperature Distributions}

Figure 4.16 shows the dCSCTM 2D temperature distribution for Phase III of control test 13 using the analysis methodology in Section 3.4.4. The temperature setpoint for the $\mathrm{dCSC}^{\mathrm{TM}}$ during Phase III of a control test is $200{ }^{\circ} \mathrm{C}$. Each row of thermocouples (radial location) shows less than $6{ }^{\circ} \mathrm{C}$ temperature difference from the front to the back of the substrate. From the center of the $\mathrm{dCSC}^{\mathrm{TM}}$ to the outermost radius there is a $13{ }^{\circ} \mathrm{C}$ temperature difference between the furthest downstream thermocouple locations in each 
row. The specific test name is shown in Figures 4.16 through 4.21, the names describe all the conditions for the test ${ }^{1}$.

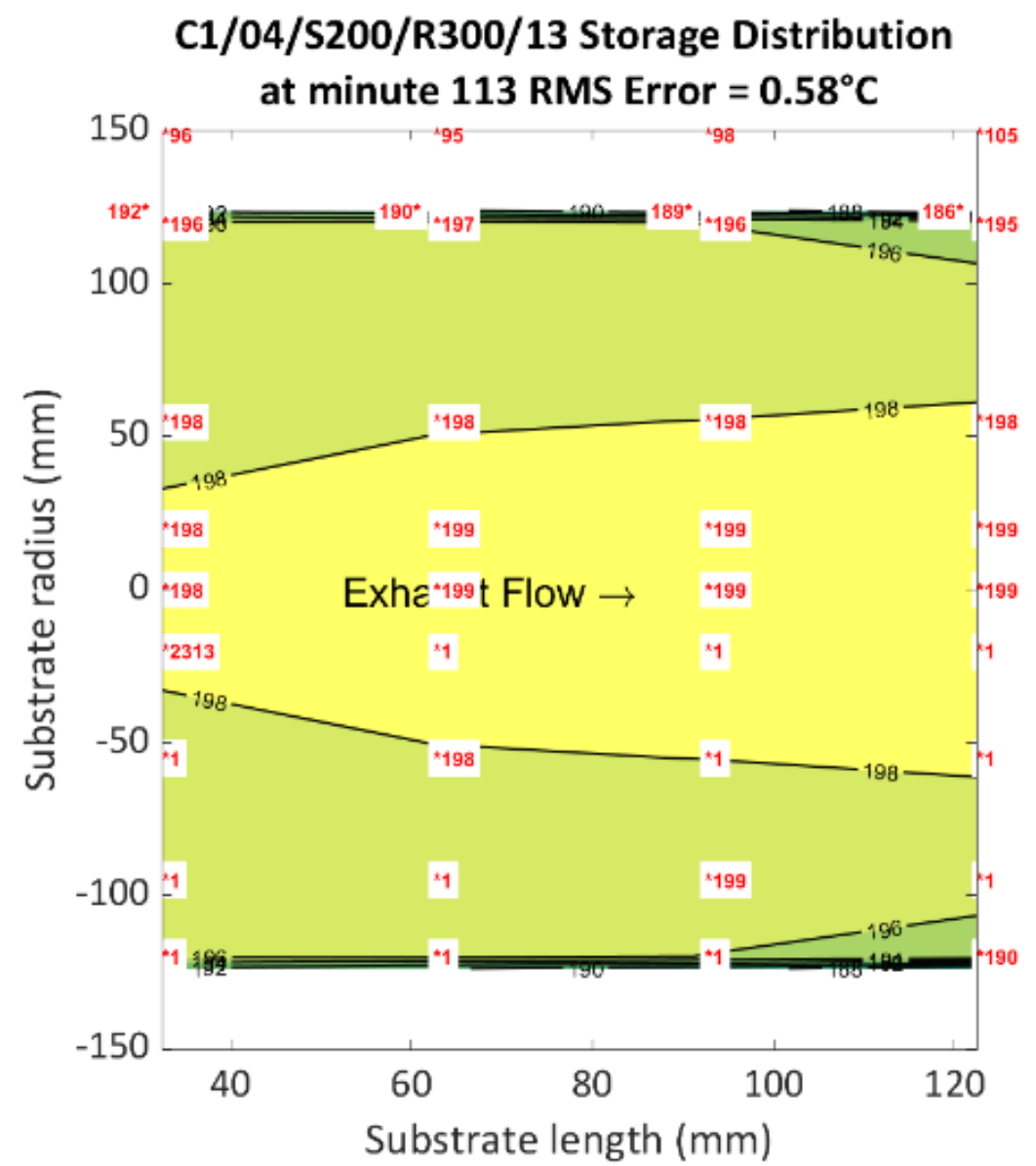

Figure 4.16 Control Test 13 at minute 113 , dCSC ${ }^{\text {TM }}$ Temperature $200{ }^{\circ} \mathrm{C}$, Phase III 2D Temperature Distribution

$1 *$ Engine Condition/Test Number/Storage Temperature $\left({ }^{\circ} \mathrm{C}\right) /$ Release Temperature $\left({ }^{\circ} \mathrm{C}\right) /$ Indicates \# of times the specific test has been run $(02=2$ nd time running test $) .-T R 1$ indicates $20^{\circ} \mathrm{C} / \mathrm{min}$ ramp rate. -TR2 indicates 
Figure 4.17 shows the $\mathrm{dCSC}^{\mathrm{TM}} 2 \mathrm{D}$ temperature distribution for a test with a $115^{\circ} \mathrm{C}$ Phase III temperature. Differing from Figure 4.16, each row of thermocouples (radial location) shows less than $3{ }^{\circ} \mathrm{C}$ temperature difference from the front to the back of the substrate. From the center of the $\mathrm{dCSC} \mathrm{CM}^{\mathrm{TM}}$ to the outermost radius there is a $6{ }^{\circ} \mathrm{C}$ temperature difference between the furthest downstream thermocouple locations in each row. Figure 4.16 showed larger temperature gradient's because the temperature setpoint was $200{ }^{\circ} \mathrm{C}$, $75^{\circ} \mathrm{C}$ higher than Figure 4.17, and room temperature is approximately the same.

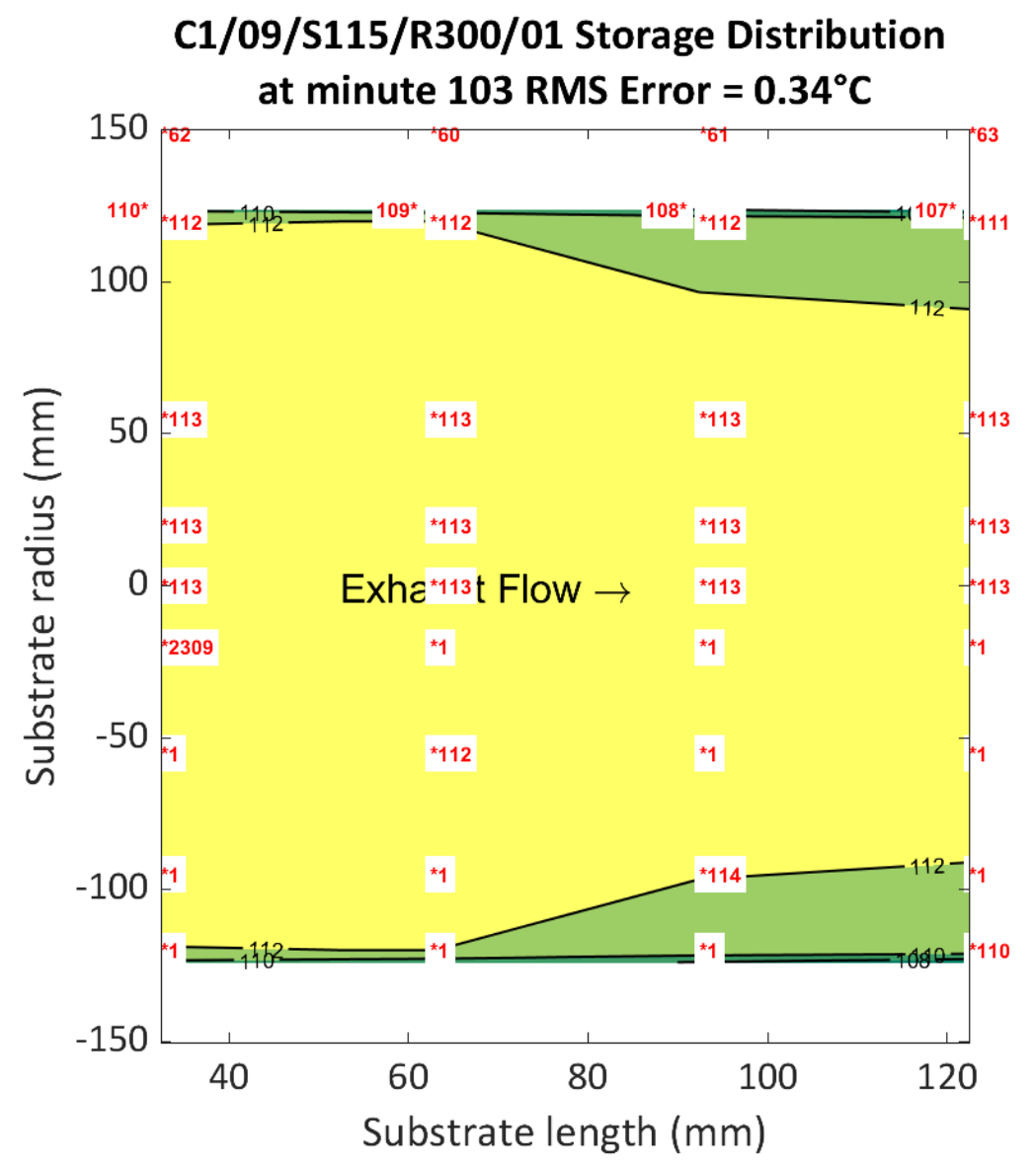

Figure 4.17 Test 9 minute 103, dCSC TM Temperature $115^{\circ} \mathrm{C}$, Phase III 2D Temperature Distribution

At the start of Phase IV, the dCSC TM temperature increases from the Phase III temperature setpoint to the Phase IV temperature setpoint. Figure 4.18 shows the dCSC ${ }^{\mathrm{TM}}$ $2 \mathrm{D}$ temperature distribution during this temperature increase. In this case it is plotted for 
control test 13 , where the temperature is increasing from 200 to $300{ }^{\circ} \mathrm{C}$, at minute 119 when the $\mathrm{dCSC} \mathrm{TM}^{\mathrm{TM}}$ temperature is approximately $250{ }^{\circ} \mathrm{C}$. During this temperature increase there is a $20^{\circ} \mathrm{C}$ temperature difference between the $\mathrm{C} 1$ and $\mathrm{C} 4$ thermocouples (front and back). There is also a 20 to $30{ }^{\circ} \mathrm{C}$ temperature difference from the center row of thermocouples to the outermost radius of the substrate.

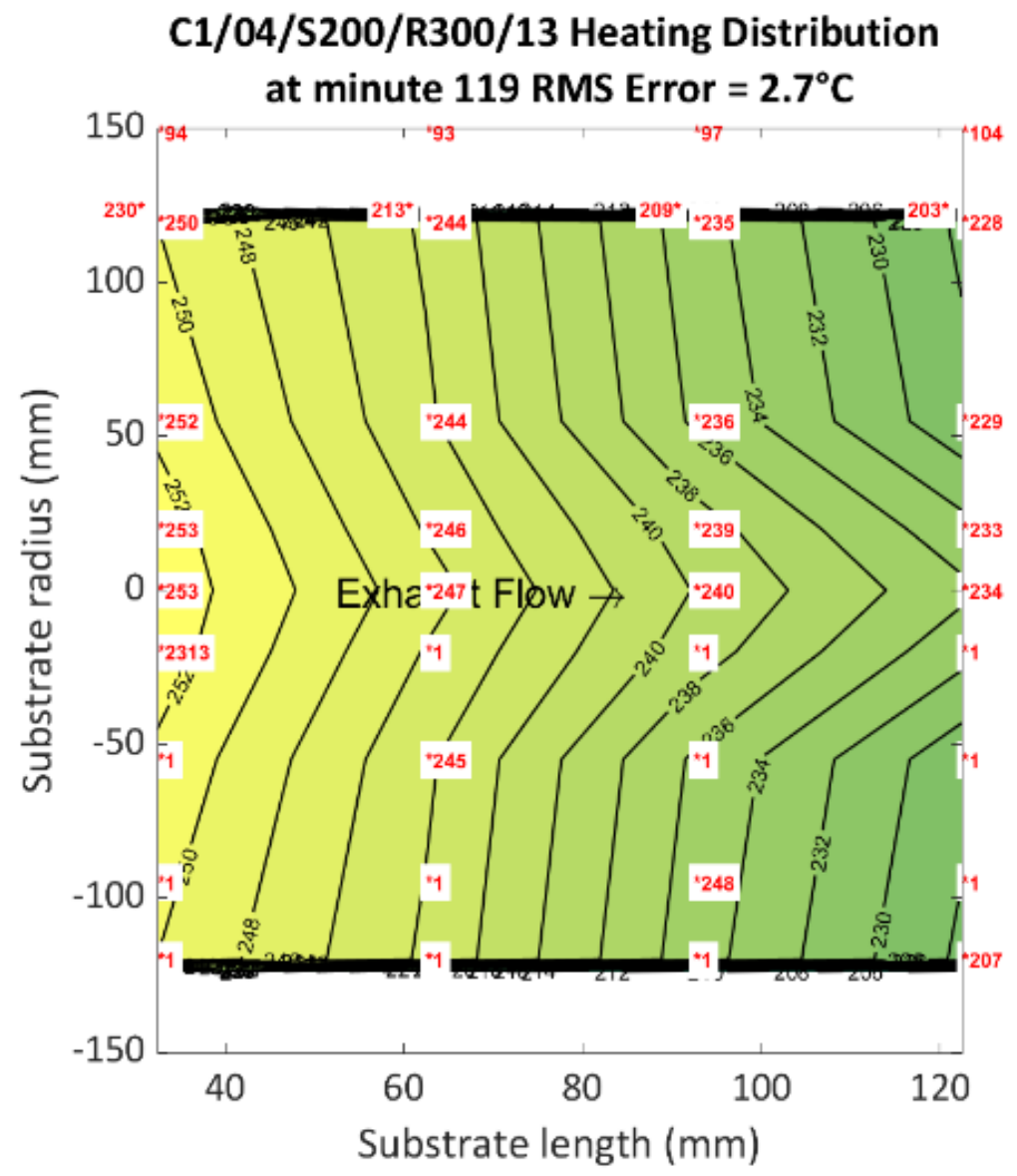

Figure 4.18 Control Test 13 at minute 119 , dCSC ${ }^{\text {TM }}$ Temperature Approximately $250^{\circ} \mathrm{C}$, Phase IV Heating (from 200 to $300^{\circ} \mathrm{C}$ ) 2D Temperature Distribution

Figure 4.19 shows the $\mathrm{dCSC} \mathrm{CM}^{\mathrm{TM}} 2 \mathrm{D}$ temperature distribution during a temperature increase from 115 to $300{ }^{\circ} \mathrm{C}$ during Phase IV. The $2 \mathrm{D}$ distribution is plotted at minute 119 when the temperature is approximately $250{ }^{\circ} \mathrm{C}$. During this temperature increase within the $\mathrm{dCSC}^{\mathrm{TM}}$ there is a $30{ }^{\circ} \mathrm{C}$ temperature difference between the $\mathrm{C} 1$ and $\mathrm{C} 4$ thermocouples (front and back). This is $10{ }^{\circ} \mathrm{C}$ higher than in Figure 4.18 because the temperature ramp 
starts at $115^{\circ} \mathrm{C}$ in Figure 4.19 rather than $200{ }^{\circ} \mathrm{C}$ in Figure 4.18. Therefore, the $\mathrm{dCSC}$ TM temperature ramps an additional $75^{\circ} \mathrm{C}$ in Figure 4.19 which makes the temperature gradient larger. There is also a $30^{\circ} \mathrm{C}$ temperature difference from the center row of thermocouples to the outermost radius of the substrate, which is on the higher end of the same gradient in Figure 4.18.

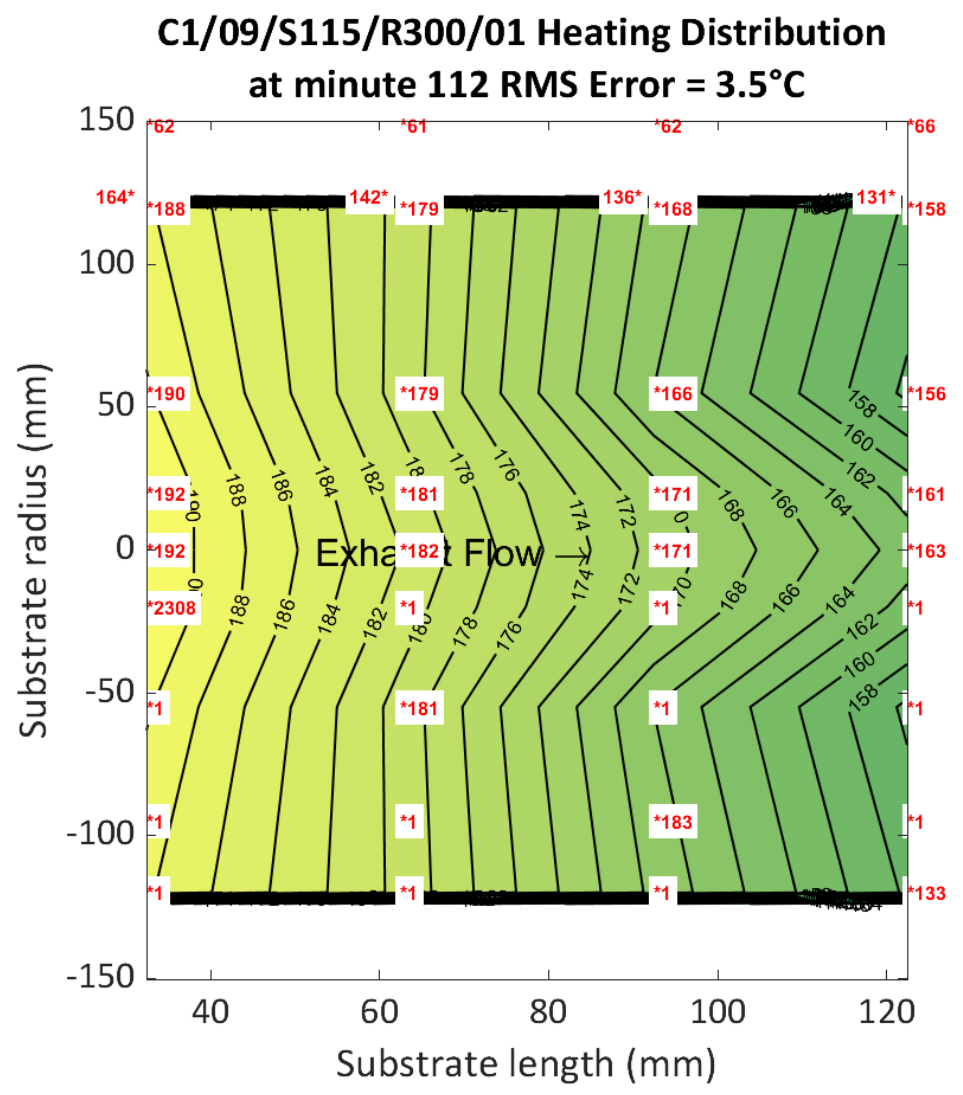

Figure 4.19 Test 9 minute 112 , dCSCTM Temperature Approximately $175^{\circ} \mathrm{C}$, Phase IV Heating (from 115 to $300{ }^{\circ} \mathrm{C}$ ) 2D Temperature Distribution

Figure 4.20 shows the $\mathrm{dCSC} \mathrm{CM}^{\mathrm{TM}} 2 \mathrm{D}$ temperature distribution at test minute 149 of control test 13 , when the $\mathrm{dCSC} \mathrm{CM}^{\mathrm{TM}}$ has reached the $300^{\circ} \mathrm{C}$ Phase IV temperature setpoint. Each row of thermocouples (radial location) shows less than $3{ }^{\circ} \mathrm{C}$ temperature difference from the front to the back of the substrate. From the center of the dCSCTM to the outermost radius there is a $26{ }^{\circ} \mathrm{C}$ temperature difference between the furthest downstream thermocouple locations in each row. This is twice the temperature difference from Figure 
4.16. This is expected because the temperature setpoint is $100^{\circ} \mathrm{C}$ higher in Figure 4.20 than 4.16 , but the room temperature is approximately the same, providing a larger temperature gradient.

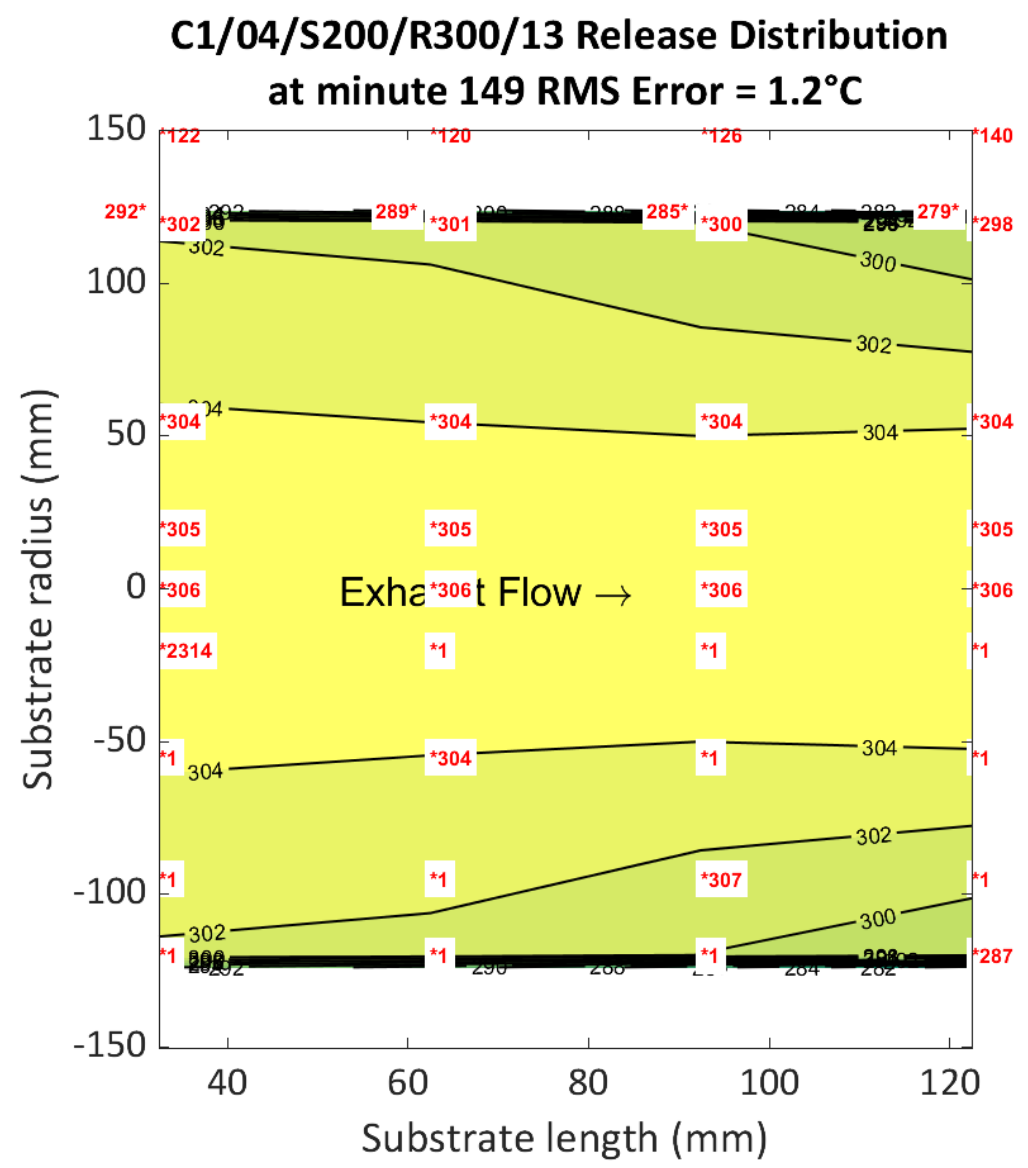

Figure 4.20 Control Test 13 at minute 149, dCSC ${ }^{\text {TM }}$ Temperature $300{ }^{\circ} \mathrm{C}$, Phase IV Release 2D Temperature Distribution

Figure 4.21 shows the $\mathrm{dCSC} \mathrm{CM}^{\mathrm{TM}} 2 \mathrm{D}$ temperature distribution at test minute 140 of test 9 , when the $\mathrm{dCSC}{ }^{\mathrm{TM}}$ has reached the $300^{\circ} \mathrm{C}$ Phase IV temperature setpoint. The temperature gradients between the thermocouples in each row, and between the rows, is within $1{ }^{\circ} \mathrm{C}$ of the temperature gradients in Figure 4.20. This is because the temperature setpoint is the same for Phase IV of both tests and test cell temperature is approximately the same. The RMS error for the dCSC ${ }^{\mathrm{TM}} 2 \mathrm{D}$ temperature distributions never exceeds 5 ${ }^{\circ} \mathrm{C}$. 


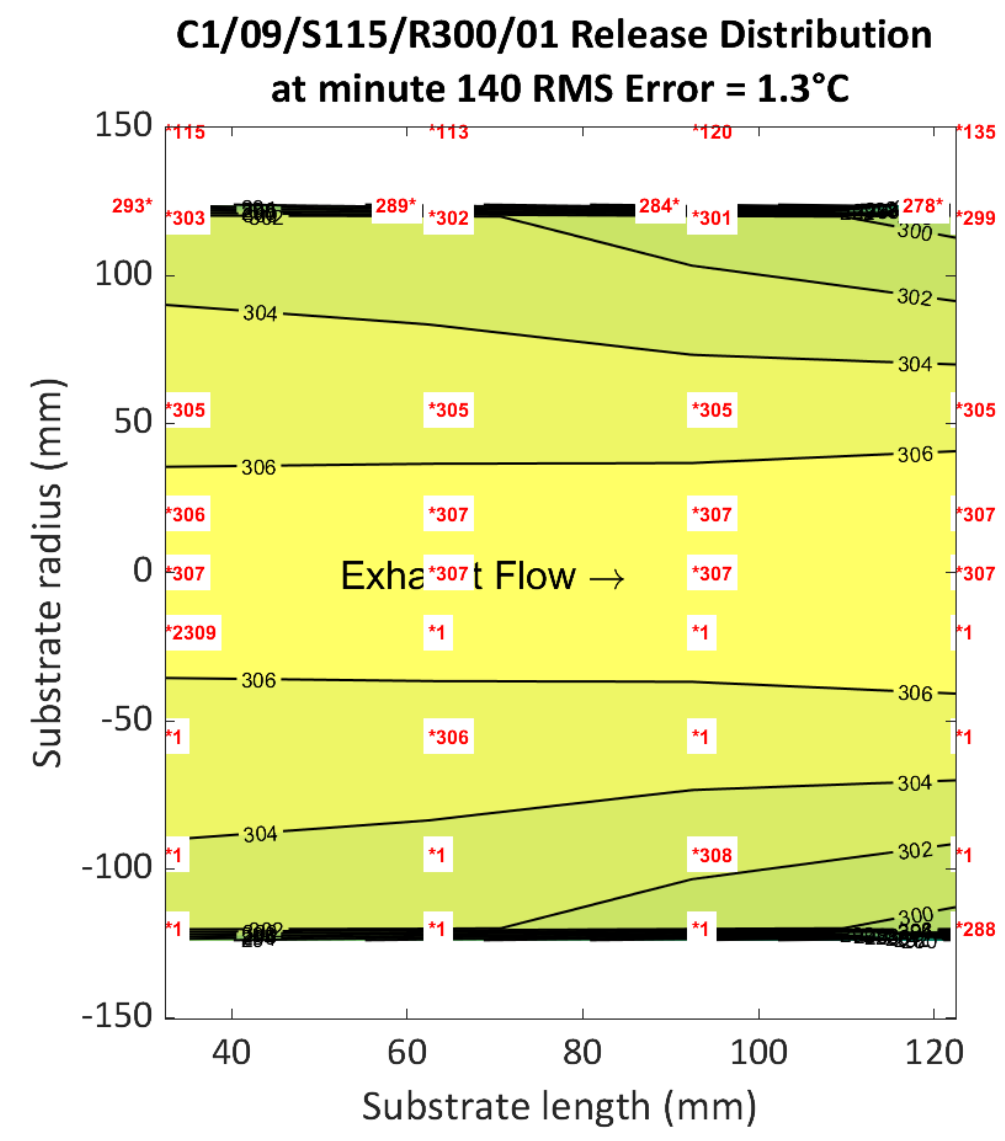

Figure 4.21 Test 9 minute $140, \mathrm{dCSC} \mathrm{TM}^{\mathrm{TM}}$ Temperature $300^{\circ} \mathrm{C}$, Phase IV Release 2D

Temperature Distribution

\subsection{Summary and Conclusions}

A literature review was conducted to determine data and fundamentals of PNA devices that are available. An engine test cell and test procedure were developed as well as a statistical test matrix. The test cell instrumentation needed to acquire the data for the high-fidelity 2D flow through model of the $\mathrm{dCSC}^{\mathrm{TM}}$ was determined. Data analysis methods were developed to determine the $\mathrm{dCSC}^{\mathrm{TM}}$ performance characteristics from the experimental data. Over 200 hours of testing was completed on the Diesel Cold Start Concept Catalyst (dCSCTM) with a 2013 Cummins ISB 6.7L $280 \mathrm{hp}$ diesel engine. 
The goal of the $\mathrm{dCSC}^{\mathrm{TM}}$ is to store $\mathrm{NO}, \mathrm{NO}_{2}, \mathrm{CO}$, and $\mathrm{HC}$ emissions at temperatures below $200{ }^{\circ} \mathrm{C}$ where the current ATS is ineffective and release them at temperatures above $200{ }^{\circ} \mathrm{C}$ when the downstream ATS has increased its temperature. A list of conclusions from the experimental results are as follows.

1. Consistent with reference [8], the $\mathrm{dCSC}^{\mathrm{TM}}$ shows significant low temperature NOx storage capability, with peak NOx storage occurring from 125 to $150^{\circ} \mathrm{C}$.

2. Once the $\mathrm{dCSC}^{\mathrm{TM}}$ temperature has been at $500{ }^{\circ} \mathrm{C}$ while being exposed to exhaust gas from the diesel engine at $1660 \mathrm{rpm}$ and $600 \mathrm{~N}-\mathrm{m}$ for 5 hours and 30 minutes the $200{ }^{\circ} \mathrm{C}$ total NOx storage capacity reduces from approximately 0.6 to 0.5 g.NOx/L.Sub. After 9 hours and 10 minutes at these conditions the $200{ }^{\circ} \mathrm{C}$ $\mathrm{dCSC}^{\mathrm{TM}}$ total NOx storage capacity reduces from 0.5 to 0.4 g.NOx/L.Sub.

3. However, during the first 200 -seconds of Phase III of testing, the $200{ }^{\circ} \mathrm{C} \mathrm{dCSC}$ TM NOx storage capacity remained nearly constant at 0.3 g.NOx/L.Sub.

4. The ability of the $\mathrm{dCSC} \mathrm{CM}^{\mathrm{TM}}$ to regain NOx storage capacity is dependent upon the release temperatures. If the $\mathrm{dCSC}^{\text {TM }}$ temperature ramped through the 200 to 265 ${ }^{\circ} \mathrm{C}$ range, rapid NOx release was observed and the substrate released over $70 \%$ of the NOx stored on the substrate. At a release temperature of $350{ }^{\circ} \mathrm{C}$, another rapid NOx release temperature range was observed and 70 to $90 \%$ of the NOx stored was released. This conclusion is supported by the data in reference [8].

5. The 250 to $350{ }^{\circ} \mathrm{C}$ temperature ramp is $60 \%$ more efficient at releasing NOx than the 250 to $300{ }^{\circ} \mathrm{C}$ temperature ramp.

6. The rapid NOx release temperature range of the $\mathrm{dCSC} \mathrm{CM}^{\mathrm{TM}}$ occurs at temperatures above $200{ }^{\circ} \mathrm{C}$. This is well within the operating temperature range of the aftertreatment system after the cold start period.

7. $\mathrm{N}_{2} \mathrm{O}$ production was measured as a result of the $\mathrm{HC}$ lean $\mathrm{NO}$ reduction that occurs on the $\mathrm{dCSC}^{\mathrm{TM}}$, this is supported by the data in reference [1]. A peak $\mathrm{N}_{2} \mathrm{O}$ concentration of $12 \mathrm{ppm}$ was measured during a $\mathrm{dCSC} \mathrm{CM}^{\mathrm{TM}}$ temperature ramp from an $80{ }^{\circ} \mathrm{C}$ Phase III to a $300{ }^{\circ} \mathrm{C}$ Phase IV. This indicates the upstream NO is 
converted to downstream $\mathrm{N}_{2} \mathrm{O}$ during the temperature ramp at the beginning of Phase IV, where NOx release is observed.

8. At temperatures from 200 to $400{ }^{\circ} \mathrm{C}$, the $\mathrm{dCSC}^{\mathrm{TM}}$ shows $50 \%$ or greater NO to $\mathrm{NO}_{2}$ oxidation. $\mathrm{NO}$ to $\mathrm{NO}_{2}$ oxidation peaks at approximately $75 \%$ at $300{ }^{\circ} \mathrm{C}$.

9. The $\mathrm{dCSC}^{\mathrm{TM}}$ also showed 50 to $70 \% \mathrm{CO}$ oxidation at temperatures of $125^{\circ} \mathrm{C}$ and below. At temperatures of $150{ }^{\circ} \mathrm{C}$ and above the $\mathrm{dCSC}$ TM oxidizes 90 to $100 \%$ of the $\mathrm{CO}$ emissions entering the substrate.

10. The RMS error of the $\mathrm{dCSC} \mathrm{CM}^{\mathrm{TM}} 2 \mathrm{D}$ temperature distributions is less than $5^{\circ} \mathrm{C}$.

\subsection{Future Work}

Modeling of the $\mathrm{dCSC}^{\text {TM }}$ substrate will take place now that the experimental data has been acquired. This model will be used to predict downstream $\mathrm{dCSC} \mathrm{CM}^{\mathrm{TM}}$ emissions concentrations at specified conditions. In conjunction with the species model an accurate thermal model of the device will be developed from all of the temperature data acquired herein.

In order to improve the temperature measurements, it is recommended that an additional row of thermocouples be instrumented within the $\mathrm{dCSC}^{\mathrm{TM}}$ substrate. Details of this recommendation are in Appendix $\mathrm{J}$.

Additional experimental research with accurate methods to measure upstream and downstream dCSC ${ }^{\text {TM }} \mathrm{HC}$ is needed. This needs to be done in order to calibrate the HC storage, release, and oxidation performance of the $\mathrm{dCSC} \mathrm{CM}^{\mathrm{TM}}$.

The NOx storage capacity of the $\mathrm{dCSC} \mathrm{TM}^{\mathrm{T}}$ is finite, therefore, the faster the more robust downstream ATS reaches its operating temperature of over $200^{\circ} \mathrm{C}$, the better.

Experimental research must be done to determine a reliable method for increasing the ATS temperature downstream of the $\mathrm{dCSC}^{\mathrm{TM}}$ as quickly as possible. Electric heaters, fuel burners, engine calibration, engine hardware, etc. have all been brought up as viable options [5, 11, 12, 13]. 


\section{References}

1. Chen, H., Mulla, S., Weigert, E., Camm, K. et al., "Cold Start Concept (CSCTM): A Novel Catalyst for Cold Start Emission Control," SAE Int. J. Fuels Lubr. 6(2):2013, doi:10.4271/2013-01-0535. (2013)

2. “Modular Aftertreatment System," Cummins Inc. [Online]. Available: https://www.cummins.com/components/aftertreatment/modular-aftertreatmentsystem. [Accessed: 09-Nov-2019].

3. CARB, "California Air Resources Board Staff Current Assessment of the Technical Feasibility of Lower NOx Standards and Associated Test Procedures for 2022 and Subsequent Model Year Medium-Duty and Heavy-Duty Diesel Engines," CARB staff white paper, (2019).

4. “Cleaner Trucks Initiative,” EPA, 21-Feb-2019. [Online]. Available: https://www.epa.gov/regulations-emissions-vehicles-and-engines/cleaner-trucksinitiative. [Accessed: 10-Nov-2019]. (2019)

5. Sharp, C., Webb, C., Neely, G., Sarlashkar, J. et al., "Achieving Ultra Low NOx Emissions Levels with a 2017 Heavy-Duty On-Highway TC Diesel Engine and an Advanced Technology Emissions System - NOx Management Strategies," SAE Int. J. Engines 10(4):2017, doi:10.4271/2017-01-0958. (2017)

6. Emission Standards, Available from: www.dieselnet.com.

7. "Low Load Cycle (LLC)," Emission Test Cycles: Low Load Cycle (LLC). [Online]. Available: https://www.dieselnet.com/standards/cycles/llc.php. [Accessed: 12-Nov-2019]. (2019)

8. Chen, H., Liu, D., Weigert, E., Cumaranatunge, L. et al., "Durability Assessment of Diesel Cold Start Concept (dCSCTM) Technologies," SAE Int. J. Engines 10(4):2017, doi:10.4271/2017-01-0955. (2017)

9. Alissa Recker, "Fuel Contaminants, Effects on Aftertreatment, and Their Limits on NOx Stringency and Extended Useful Life", presentation, University of Wisconsin Madison symposium on technologies to meet ultra-low NOx standards. https://www.erc.wisc.edu/symposium2019.php. (2019) 
10. Naseri, M., Aydin, C., Mulla, S., Conway, R. et al., "Development of Emission Control Systems to Enable High NOx Conversion on Heavy Duty Diesel Engines," SAE Int. J. Engines 8(3):2015, doi:10.4271/2015-01-0992. (2015)

11. Culbertson, D., Pradun, J., Khair, M., and Diestelmeier, J., "Development of Robust Electric Heating System for Medium Duty Diesel Vehicles," SAE Technical Paper 2017-01-0937, doi:10.4271/2017-01-0937. (2017)

12. Magee, Mark E. "Exhaust Thermal Management Using Cylinder Deactivation and Late Intake Valve Closing.” MS Thesis, Purdue University, May, (2014)

13. Sharp, C., Webb, C., Neely, G., Carter, M. et al., "Achieving Ultra Low NOX Emissions Levels with a 2017 Heavy-Duty On-Highway TC Diesel Engine and an Advanced Technology Emissions System - Thermal Management Strategies," SAE Int. J. Engines 10(4):2017, doi:10.4271/2017-01-0954. (2017)

14. J. M. S. E. Control, “Ammonia slip catalysts,” JM Stationary Emissions Control. [Online]. Available: https://www.jmsec.com/air-pollution-solutions/selectivecatalytic-reduction-scr/ammonia-slip-catalysts/?L=0. [Accessed: 10-Nov-2019].

15. W. A. Majewski, "Selective Catalytic Reduction," Selective Catalytic Reduction [Online]. Available: https://www.dieselnet.com/tech/cat_scr.php. [Accessed: 10Nov-2019]. (2005)

16. Sharp, C., Webb, C., Yoon, S., Carter, M. et al., "Achieving Ultra Low NOX Emissions Levels with a 2017 Heavy-Duty On-Highway TC Diesel Engine Comparison of Advanced Technology Approaches," SAE Int. J. Engines 10(4):2017, doi:10.4271/2017-01-0956. (2017)

17. Zheng, Y., "Low-Temperature Pd/Zeolite Passive NOx Adsorbers: Structure, Performance, and Adsorption Chemistry." The Journal of Physical Chemistry C 121(29): 15793-15803. (2017)

18. Chen, H. Y.; Collier, J. E.; Liu, D. X.; Mantarosie, L.; Duran-Martin, D.; Novak, V.; Rajaram, R. R.; Thompsett, D. Low Temperature NO Storage of Zeolite Supported Pd for Low Temperature Diesel Engine Emission Control. Catal. Lett. 2016, 146, 1706-1711.(2016) 
19. S. Malamis, M.P. Harold, W.S. Epling, "Coupled NO and C3H6 Trapping, Release and Conversion on Pd-BEA: Evaluation of The Lean Hydrocarbon $\mathrm{NO} \neg \mathrm{x}$ Trap," in press, Ind. Eng. Chem. Res. (2019)

20. Vu, A.; Luo J.; Li, J.; Epling, W.S.; Effects of CO on Pd/BEA Passive $\mathrm{NO}_{\mathrm{x}}$ Adsorbers. Catal. Lett. 2017, 147, 745-750. (2017)

21. "An Experimental Investigation of the Effect of Temperature and Space Velocity on the Performance of a Cu-Zeolite Flow-through SCR and a SCR Catalyst on a DPF with and without PM Loading," Vaibhav Kadam, MS Thesis, Michigan Technological University, (2016)

22. “An Experimental Investigation into NO2 Assisted Particulate Oxidation With and Without Urea and Active Regeneration of Particulate Matter in a SCR Catalyst on a DPF," Erik Gustafson, MS Thesis, Michigan Technological University, (2016)

23. "Catalyst Fundamentals," Catalyst Fundamentals. [Online]. Available: https://www.dieselnet.com/tech/cat_fund.php\#rate. [Accessed: 11-Nov-2019].

24. Pihl, J., Majumdar, S.S., NO adsorption and desorption phenomena on a Pdexchanged zeolite passive NOx adsorber, CLEERS Workshop, September 19, (2018)

25. Heywood, John B., Internal Combustion Engine Fundamentals. New York: McGraw-Hill, (1988)

26. James Sanchez, "EPA's Cleaner Trucks Initiative”, presentation, University of Wisconsin Madison symposium on technologies to meet ultra-low NOx systems. https://www.erc.wisc.edu/symposium2019.php (2019)

27. W.A. Majewski, "Diesel Oxidation Catalyst," Diesel Oxidation Catalyst [Online]. Available: https://www.dieselnet.com/tech/cat_doc.php. [Accessed: 6-Dec-2019]. (2018)

28. Malamis, S., Ambast, M., Harold, M.P., Epling, Coupled NO and C3H6 trapping, release and conversion on Pd-BEA, W., CLEERS Workshop, September 19, (2018) 


\section{Appendix A. $\quad$ Heater PID Tuning}

Tuning of the heater PID controller was needed in order to achieve zero steady state temperature error. $10{ }^{\circ} \mathrm{C}$ temperature oscillations were observed when attempting to hold the temperature constant, as shown in Figure A.1. The C1, C2, C3, and C4 thermocouples are on the centerline of the $\mathrm{dCSC}^{\mathrm{TM}}$ substrate spaced evenly from front to back, respectively.

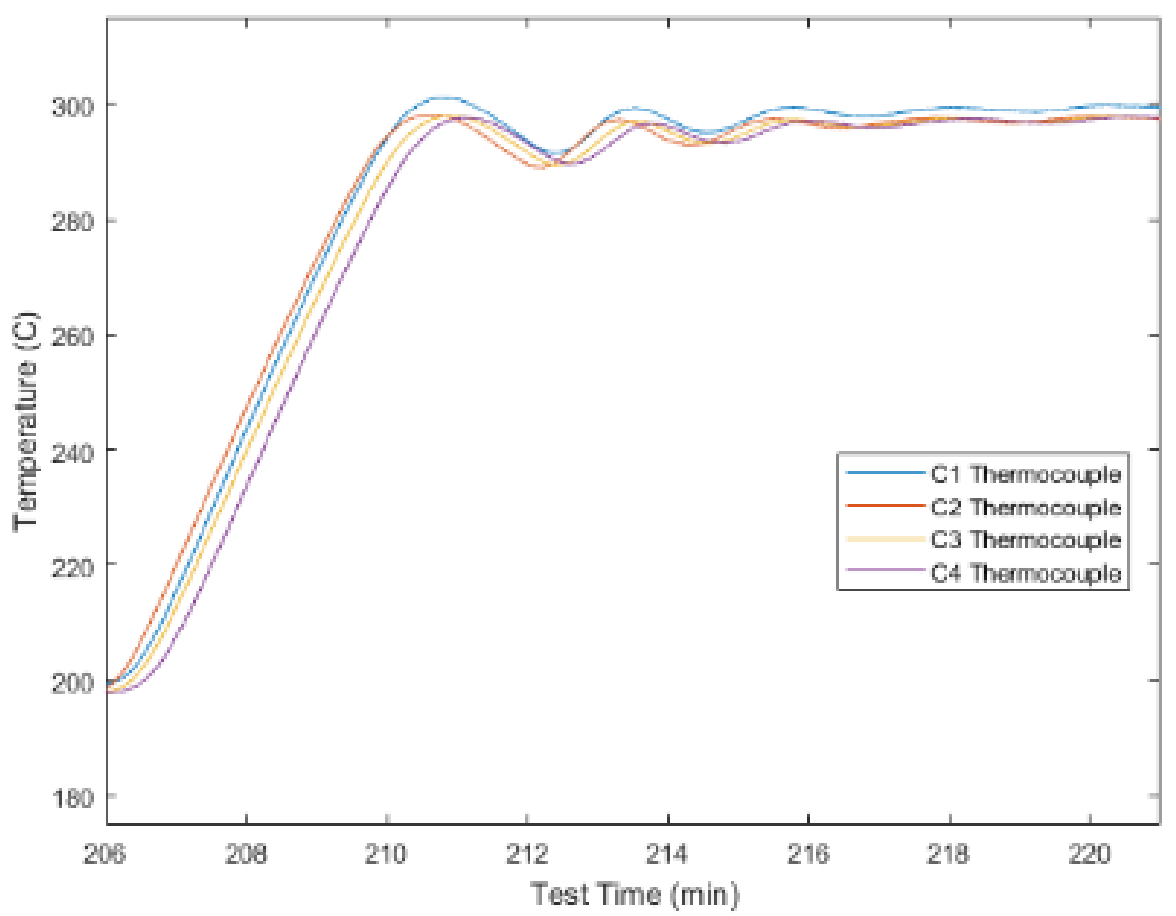

A.1 Watlow Heater Temperature Data Showing Oscillating Response

By tuning the heater controller all temperature oscillations were eliminated. As shown in Figure A.2, the $\mathrm{dCSC}^{\mathrm{TM}}$ thermocouple data achieve steady state readings. 


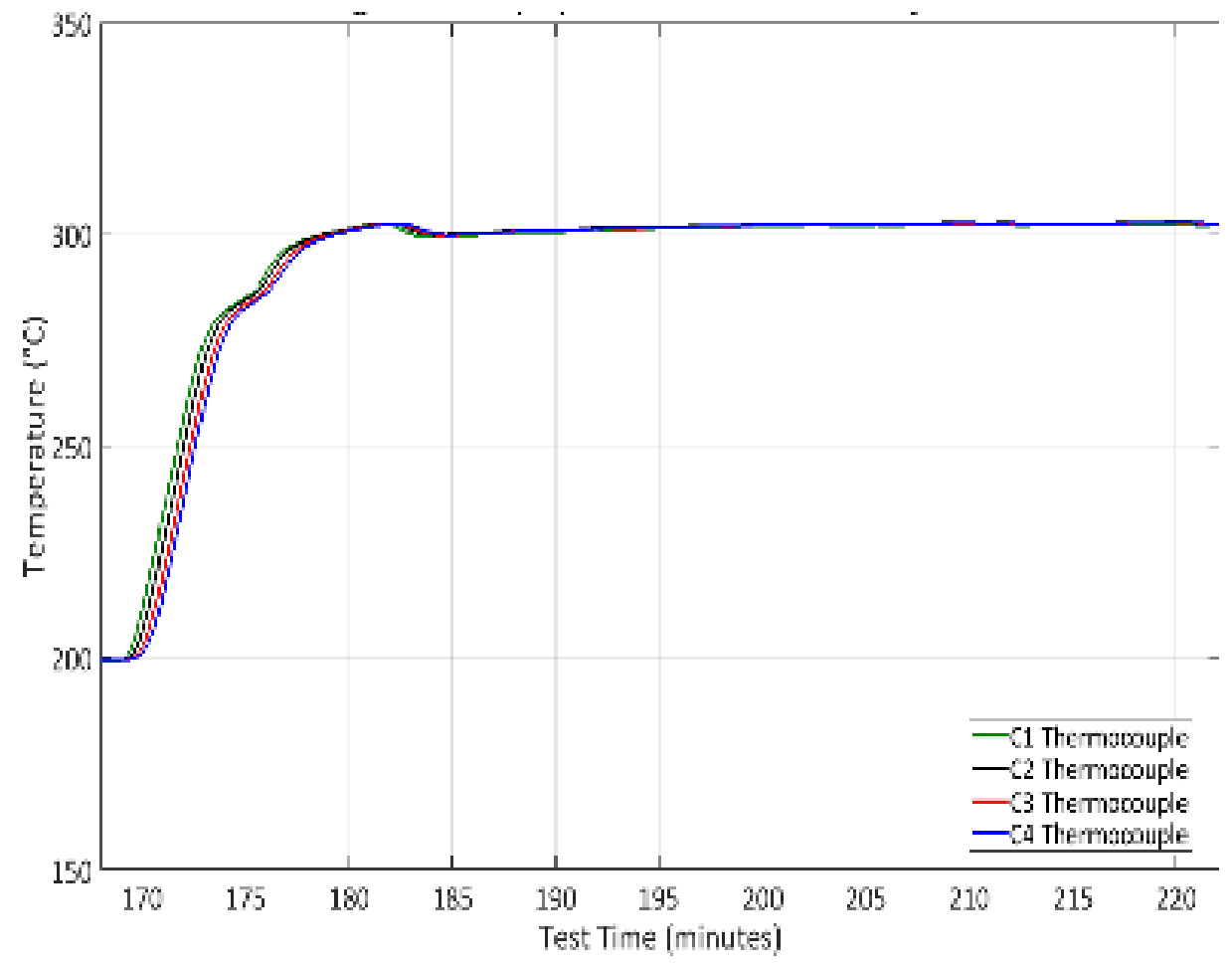

A.2 Watlow Heater Temperature Response Data After Tuning 


\section{Appendix B. $\quad$ Emissions Instrumentation}

\section{B.1 Pierburg 5-Gas Bench}

The Pierburg 5-Gas bench was utilized to measure exhaust gas concentrations of CO, $\mathrm{CO}_{2}, \mathrm{NO}, \mathrm{NO}_{2}$, and $\mathrm{O}_{2}$. In addition, the bench is setup to measure exhaust gas concentrations from two different locations within the ATS. With the control of solenoid valves, air pressure regulates one-way valves open or closed. By opening one valve and closing another, it is possible to switch from upstream dCSC ${ }^{\mathrm{TM}}$ sampling to downstream sampling in seconds. A list of the measuring methods for each exhaust gas constituent is in Table B.1.

Table B.1 Pierburg 5-Gas Bench Analyzer Types

\begin{tabular}{|c|c|c|}
\hline Exhaust Gas Constituent & Detection Method & Notes: \\
\hline $\mathrm{O}_{2}$ & Paramagnetic & \\
\hline $\mathrm{CO}_{2}$ & $\mathrm{IRD}$ & \\
\hline $\mathrm{CO}$ & $\mathrm{IRD}$ & \\
\hline $\mathrm{NO}$ & Chemiluminescence & \\
\hline $\mathrm{NO}_{2}$ & $\begin{array}{c}\mathrm{NO}_{2} \text { to NO converter, } \\
\text { Chemiluminescence }\end{array}$ & \\
\hline Total Hydrocarbons & Flame Ionization (FID) & $\begin{array}{l}\text { Not able to measure with } \\
\text { current sampling system. }\end{array}$ \\
\hline
\end{tabular}

$\mathrm{NO}_{2}$ is not directly measured, it is first converted from $\mathrm{NO}_{2}$ to $\mathrm{NO}$ and then measured with the Pierburg Chemiluminescence detection system. Due to the long lengths of sample line from the ATS, total hydrocarbons could not be measured with the Pierburg FID. 


\section{B.2 Cambustion Fast NO and NOx CLD}

Cambustion's fNO400 CLD Fast Response NO measuring system was used to measure $\mathrm{NO}$ and $\mathrm{NOx}$ downstream of the $\mathrm{dCSC}^{\mathrm{TM}}$. In order to measure total $\mathrm{NOx}, \mathrm{a} \mathrm{NO}_{2}$ to $\mathrm{NO}$ converter was placed in line with channel 2 of the fNO400 system. Figures B. 1 and B.2 illustrate the Cambustion sampling system. Figure B.1 shows the sampling locations of both Cambustion channels (Fast NO and Fast NOx), a production NOx sensor, and the downstream sample location for the Pierburg 5-gas bench and Thermo Fisher $\mathrm{N}_{2} \mathrm{O}$ analyzer.

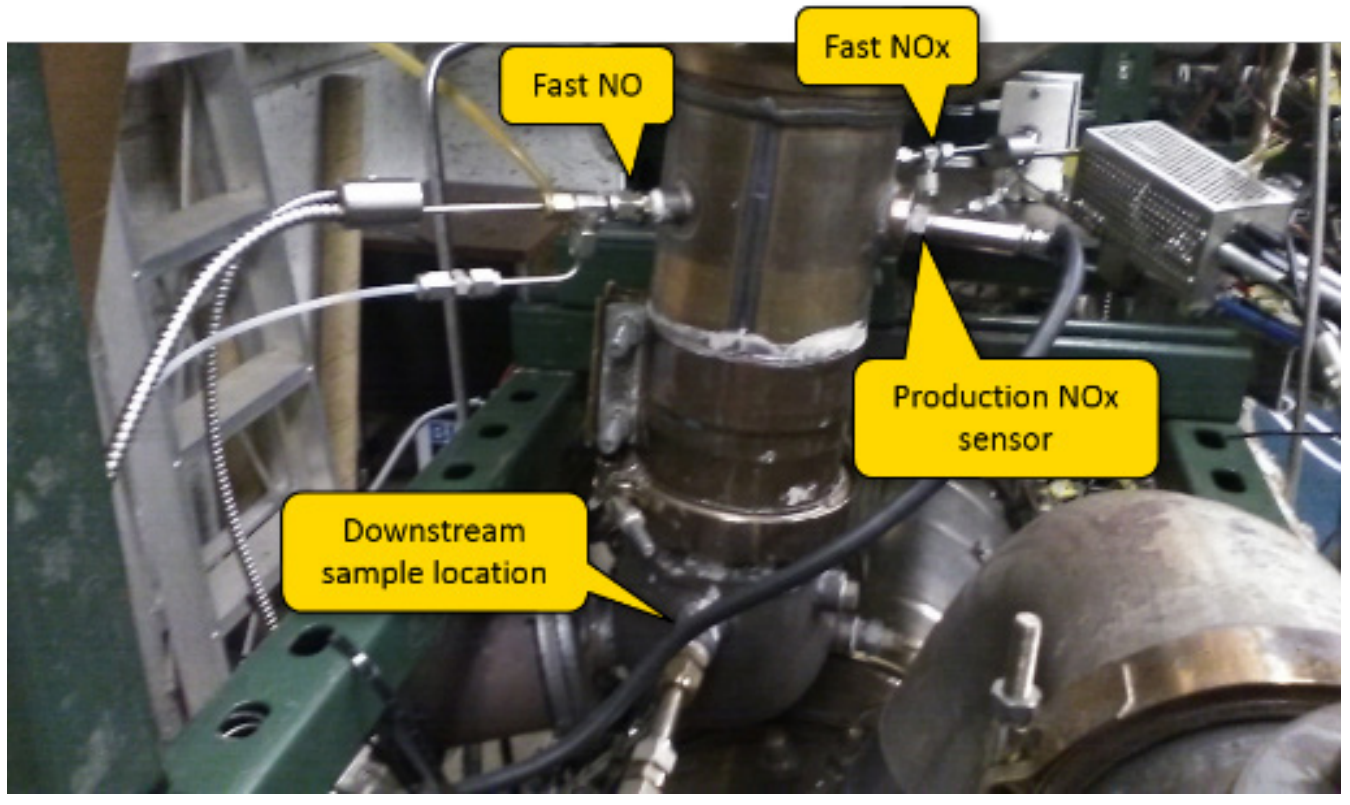

B.1 Downstream dCSCTM NOx Sample Locations.

Figure B. 2 shows the $\mathrm{NO}_{2}$ to $\mathrm{NO}$ converter placed directly in line with the Cambustion fNO400 channel 2 sampling system. Fittings were fabricated in order to allow the converter to be mounted in between the sample probe and sample head. 


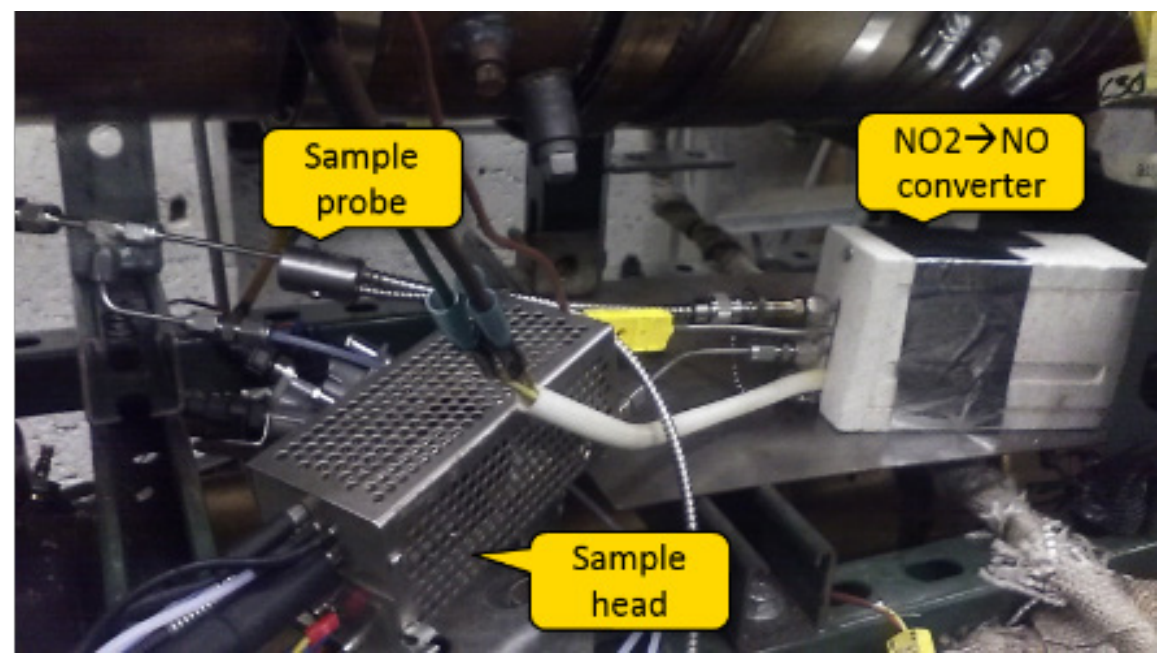

B.2 Cambustion fNO400 CLD NOx Channel Setup

The Cambustion fNO400 CLD Fast Response system has a 4 ms response time of the CLD output from $90 \%$ to $10 \%$ NO concentration. This is in response to a step input at the sample source. Insitu calibration is achieved via flooding the entire sampling system with calibration gas.

\section{B.3 Cambustion HFR 400 Fast FID}

A Cambustion HFR 400 Fast FID measured total hydrocarbon concentrations in the exhaust. Similar to the fNO400 CLD system the HFR 400 has two measuring channels, insitu calibration, and a $4 \mathrm{~ms} 10-90 \%$ response time of the FID output for a step input at the source. The FID fuel is pure hydrogen $\left(\mathrm{H}_{2}\right)$.

\section{B.4 Thermo Fisher 46i $\mathrm{N}_{2} \mathrm{O}$ IRD}

The range of this analyzer is 0 to $50 \mathrm{ppm}$ with a $60 \mathrm{~s} 10-90 \%$ response time to a step input. This system samples in parallel with the Pierburg 5-gas bench. It was initially a concern that $\mathrm{CO}_{2}$ might cause and interference while measuring $\mathrm{N}_{2} \mathrm{O}$. In Figure B.3, it is shown that the $\mathrm{N}_{2} \mathrm{O}$ analyzer does measure a concentration of $\mathrm{N}_{2} \mathrm{O}$ when exposed to a constant $\mathrm{CO}_{2}$ concentration. However, the $\mathrm{CO}_{2}$ concentration during testing is constant, therefore the interference is constant. By taking an upstream $\mathrm{dCSC}^{\mathrm{TM}}$ measurement with 
the $\mathrm{N}_{2} \mathrm{O}$ analyzer, the constant $\mathrm{CO}_{2}$ interference can be accounted for. The $\mathrm{N}_{2} \mathrm{O}$ measurement upstream of the dCSCTM is subtracted from the $\mathrm{N}_{2} \mathrm{O}$ measurements downstream of the dCSCTM. The $\mathrm{N}_{2} \mathrm{O}$ analyzer was logged in LabVIEW.

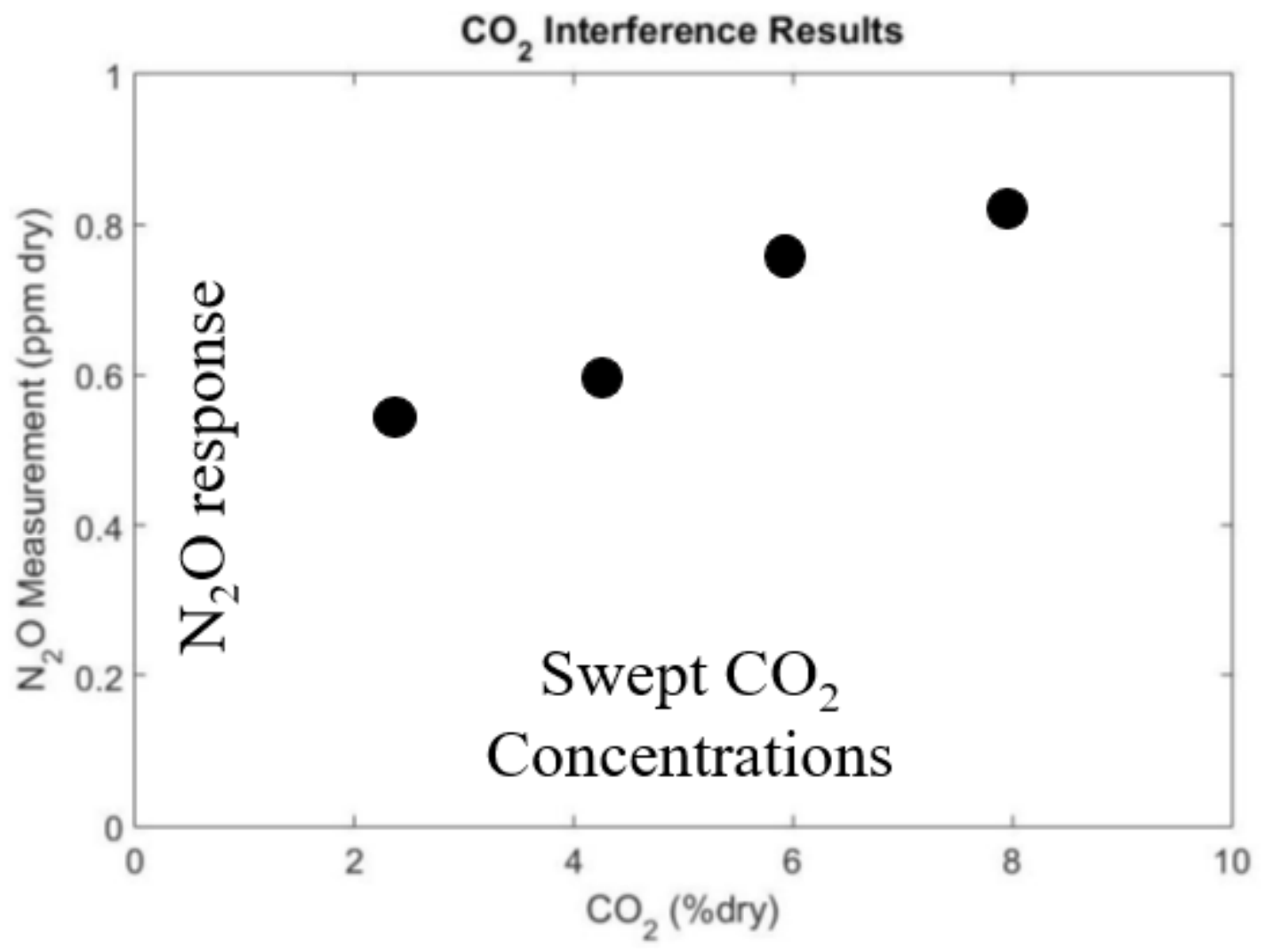

B. $3 \mathrm{~N}_{2} \mathrm{O}$ Analyzer $\mathrm{CO}_{2}$ Concentration Interference

\section{B.5 NOx Sensors}

Two production NOx sensors are setup to measure engine out NOx and downstream $\mathrm{dCSC}^{\mathrm{TM}}$ NOx concentrations. The error of these sensors is +-10 ppm or $10 \%$, whichever is greater. The sensors' output were logged using Cummins Calterm Software. In order to ensure the NOx sensors were on at all times, the ATS temperature sensors were clamped in a heater to keep them above $200{ }^{\circ} \mathrm{C}$ during testing. If these sensors dropped below 200 ${ }^{\circ} \mathrm{C}$, the NOx sensors would shut off to protect them from condensation. 


\section{Appendix C. $\quad$ Paragon ULSD \#2 Fuel Analysis Results}

Table C.1 Paragon ULSD \#2 Fuel Analysis Results

ANALYTICAL RESULTS

Workorder: $224870 \mathrm{MICH}$ TECH-080618

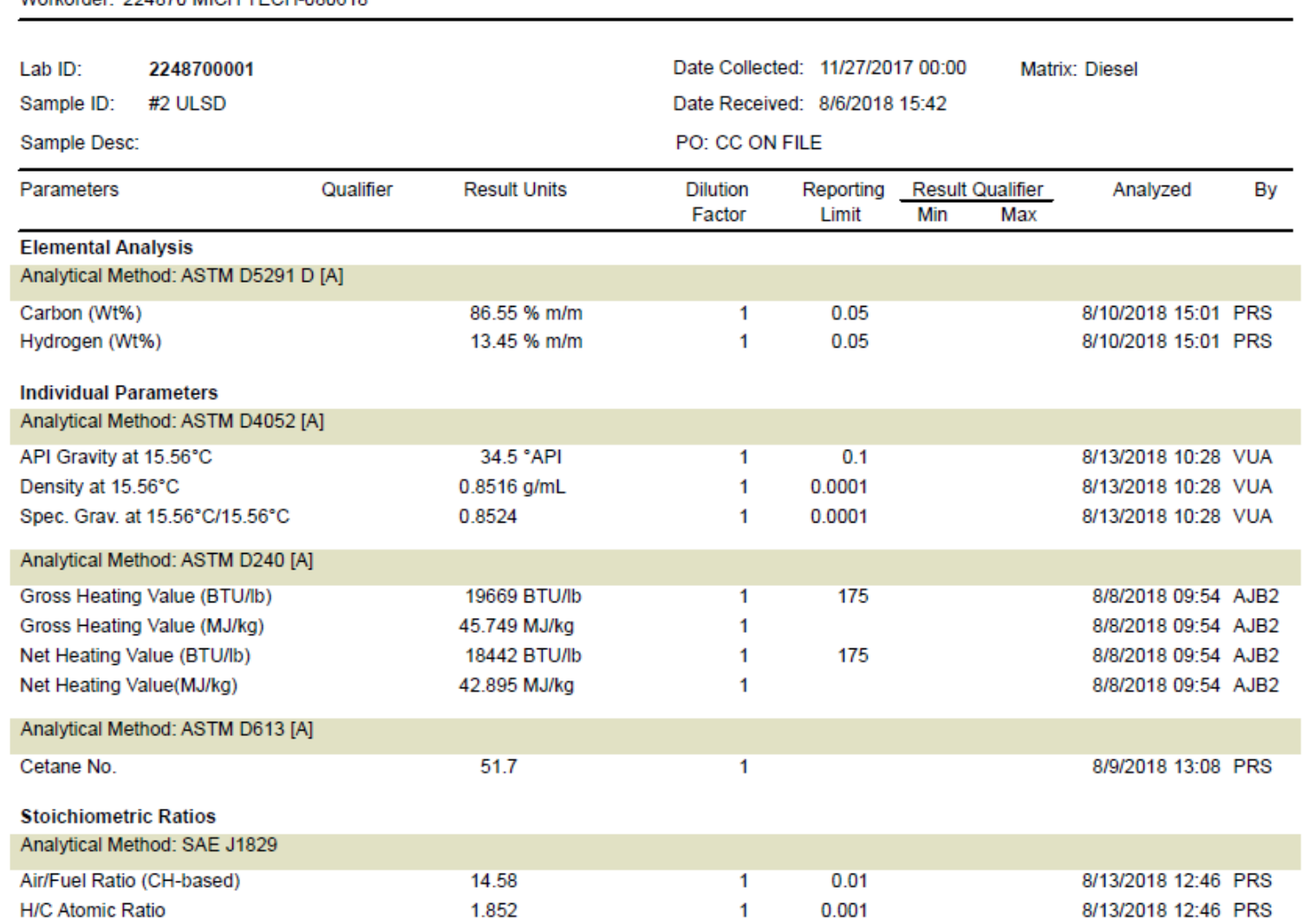


Table D.1 Experimental Testing Matrix

\begin{tabular}{|c|c|c|c|c|c|}
\hline $\begin{array}{c}\text { Run } \\
\text { Order }\end{array}$ & Test Name & $\begin{array}{c}\text { Engine } \\
\text { Condition }\end{array}$ & $\begin{array}{c}\text { Phase III } \\
\text { Storage } \\
\text { Temp. } \\
\left({ }^{\circ} \mathrm{C}\right)\end{array}$ & $\begin{array}{c}\text { Phase IV } \\
\text { Release } \\
\text { Temp. } \\
\left({ }^{\circ} \mathrm{C}\right)\end{array}$ & $\begin{array}{c}\text { Temp. } \\
\text { Ramp } \\
\left({ }^{\circ} \mathrm{C} / \text { minute }\right)\end{array}$ \\
\hline 22 & $\mathrm{C} 1 / 01 / \mathrm{S} 100 / \mathrm{R} 300$ & 1 & 100 & 300 & N/A \\
\hline 6 & $\mathrm{C} 1 / 02 / \mathrm{S} 125 / \mathrm{R} 300$ & 1 & 125 & 300 & N/A \\
\hline 3 & $\mathrm{C} 1 / 03 / \mathrm{S} 150 / \mathrm{R} 300$ & 1 & 150 & 300 & N/A \\
\hline 16 & $\mathrm{C} 1 / 04 / \mathrm{S} 200 / \mathrm{R} 300$ & 1 & 200 & 300 & N/A \\
\hline 11 & $\mathrm{C} 1 / 05 / \mathrm{S} 225 / \mathrm{R} 300$ & 1 & 225 & 300 & N/A \\
\hline 7 & $\mathrm{C} 1 / 06 / \mathrm{S} 250 / \mathrm{R} 300$ & 1 & 250 & 300 & N/A \\
\hline 17 & $\mathrm{C} 1 / 07 / \mathrm{S} 200 / \mathrm{R} 350$ & 1 & 200 & 350 & N/A \\
\hline 14 & $\mathrm{C} 1 / 08 / \mathrm{S} 250 / \mathrm{R} 350$ & 1 & 250 & 350 & N/A \\
\hline 8 & $\mathrm{C} 2 / 09 / \mathrm{S} 115 / \mathrm{R} 300$ & 2 & 115 & 300 & N/A \\
\hline 5 & $\mathrm{C} 2 / 10 / \mathrm{S} 150 / \mathrm{R} 300$ & 2 & 150 & 300 & N/A \\
\hline 21 & $\mathrm{C} 2 / 11 / \mathrm{S} 200 / \mathrm{R} 300$ & 2 & 200 & 300 & N/A \\
\hline 19 & $\mathrm{C} 2 / 12 / \mathrm{S} 250 / \mathrm{R} 300$ & 2 & 250 & 300 & N/A \\
\hline 15 & $\mathrm{C} 1 / 13 / \mathrm{S} 150 / \mathrm{R} 200$ & 1 & 150 & 200 & N/A \\
\hline 1 & $\mathrm{C} 1 / 14 / \mathrm{S} 150 / \mathrm{R} 250$ & 1 & 150 & 250 & N/A \\
\hline 23 & $\mathrm{C} 1 / 15 / \mathrm{S} 150 / \mathrm{R} 300$ & 1 & 150 & 300 & N/A \\
\hline 2 & $\mathrm{C} 1 / 16 / \mathrm{S} 150 / \mathrm{R} 350$ & 1 & 150 & 350 & N/A \\
\hline 4 & $\mathrm{C} 1 / 17 / \mathrm{S} 150 / \mathrm{R} 400$ & 1 & 150 & 400 & N/A \\
\hline 18 & $\mathrm{C} 2 / 18 / \mathrm{S} 150 / \mathrm{R} 300$ & 2 & 150 & 300 & N/A \\
\hline 13 & $\mathrm{C} 2 / 19 / \mathrm{S} 150 / \mathrm{R} 350$ & 2 & 150 & 350 & N/A \\
\hline 9 & $\mathrm{C} 1 / 20 / \mathrm{S} 125 / \mathrm{R} 300$ & 1 & 125 & 300 & N/A \\
\hline 20 & $\mathrm{C} 1 / 21 / \mathrm{S} 200 / \mathrm{R} 300$ & 1 & 200 & 300 & N/A \\
\hline 10 & $\mathrm{C} 1 / 22 / \mathrm{S} 150 / \mathrm{R} 350-\mathrm{TR} 1$ & 1 & 150 & 350 & 20 \\
\hline 12 & $\mathrm{C} 1 / 23 / \mathrm{S} 150 / \mathrm{R} 350-\mathrm{TR} 2$ & 1 & 150 & 350 & 40 \\
\hline 24 & $\mathrm{C} 3 / 24 / \mathrm{S} 080 / \mathrm{R} 300$ & 3 & 80 & 300 & N/A \\
\hline 25 & $\mathrm{C} 1 / 25 / \mathrm{S} 150 / \mathrm{R} 450$ & 1 & 150 & 450 & N/A \\
\hline & & & & & \\
\hline
\end{tabular}

*Engine Condition/Test Number/ Phase III Storage Temperature $\left({ }^{\circ} \mathrm{C}\right) /$ Phase IV Release Temperature $\left({ }^{\circ} \mathrm{C}\right) /$ Indicates \# of times the specific test has been run $(02=2$ nd time running test). -TR1 indicates $20^{\circ} \mathrm{C} / \mathrm{min}$ ramp rate. -TR2 indicates 


\section{Appendix E. Calculation of dCSCTM Volume Weighted Temperature}

First, the total volume of instrumented $\mathrm{dCSC}^{\mathrm{TM}}$ is calculated using Equation D.1.

$$
V_{T . V .}=\pi * r_{T . V .}{ }^{2} * L_{T . V .}
$$

Where $V_{T . V .}$ is the instrumented dCSCTM total volume, $r_{T . V}$ is the outermost radius of the instrumented dCSC ${ }^{\mathrm{TM}}$, and $L_{T . V}$. is the total length of the instrumented dCSC ${ }^{\mathrm{TM}}$. The radius of cylindrical volume that each thermocouple represents is calculated by Equation D.2.

$$
r_{W}=\sqrt{\frac{r_{O . T .}{ }^{2}+r_{T . C .}{ }^{2}}{2}}
$$

Where $r_{W}$ is the radius of cylindrical volume that the thermocouple represents. $r_{\text {O.T. }}$ is the radial location of the next outer thermocouple and $r_{T . C .}$ is the radial location of the thermocouple being weighted. The axial length of $\mathrm{dCSC}^{\mathrm{TM}}$ substrate each thermocouple represents is calculated using Equation D.3.

$$
L_{T . C .}=\frac{L_{U}}{2}-\frac{L_{D}}{2}
$$

$L_{T . C .}$ is the axial length of substrate that the thermocouple represents. $L_{U}$ is the axial length of substrate to the next thermocouple or $\mathrm{dCSC}^{\mathrm{TM}}$ edge upstream and $L_{D}$ is the axial length of substrate to the next thermocouple or dCSCTM edge downstream. Equation D.4 is then used to calculate the $\mathrm{dCSC}{ }^{\mathrm{TM}}$ volume that each thermocouple represents.

$$
V_{\text {T.C. }}=\left(\pi * r_{W}{ }^{2} * L_{T . C .}\right)-V_{\text {I.T.C. }}
$$


$V_{T . C .}$ is the $\mathrm{dCSC}^{\mathrm{TM}}$ volume each thermocouple represents and $V_{\text {I.T.C. }}$ is the volume represented by the next inner radial thermocouple. Equation D.5 is used to calculate the weight applied to each thermocouple reading.

$$
W_{T . C .}=\frac{V_{T . C .}}{V_{T . V .}}
$$

$W_{\text {T.C. }}$ is the weight applied to each thermocouple reading. $V_{T . C .}$ is the volume that each thermocouple represents and $V_{T . V}$. is the total volume of instrumented dCSC ${ }^{\mathrm{TM}}$. From Equation D.5 and the thermocouple readings, Equation D.6 was developed to calculate the $\mathrm{dCSC}^{\mathrm{TM}}$ volume weighted temperature.

$$
T_{V . W .}=\sum_{i=1}^{24}\left(W_{T . C .(i)} * T_{\text {T.C. }(i)}\right)
$$

Where $T_{V . W .}$, is the volume weighted temperature of the $\mathrm{dCSC} C^{\mathrm{TM}}$ substrate and $T_{T . C .(i)}$ is the reading of each thermocouple used in the calculation. $W_{\text {T.C.(i) }}$ is the weight applied to each corresponding thermocouple reading. The thermocouples' used in Equation D.6 are C1-20 and $\mathrm{C} 25-\mathrm{C} 28$. 


\section{Appendix F. $\quad$ Emissions Timeplots During Testing}

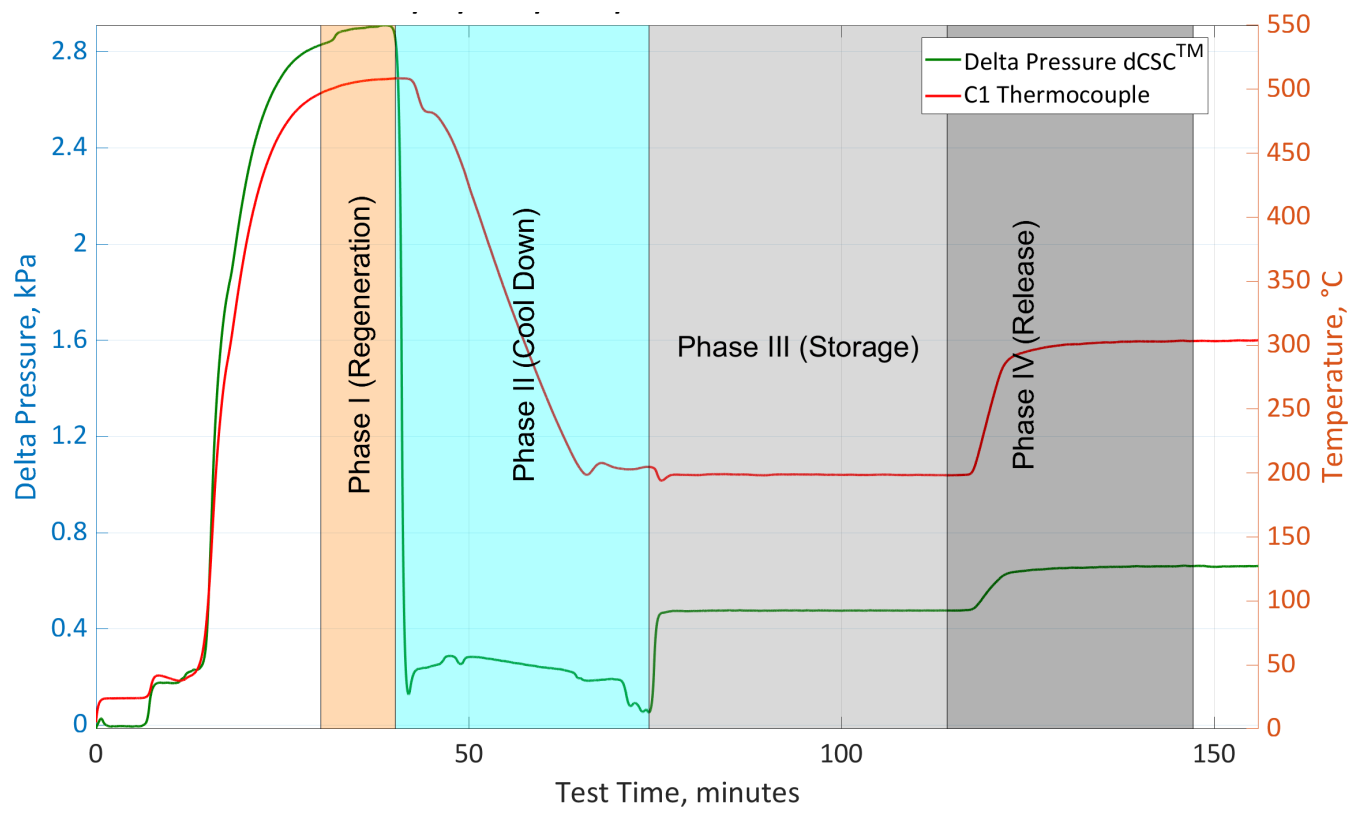

F.1 Control Test dCSC ${ }^{\text {TM }}$ Delta Pressure during Test Phases I-IV

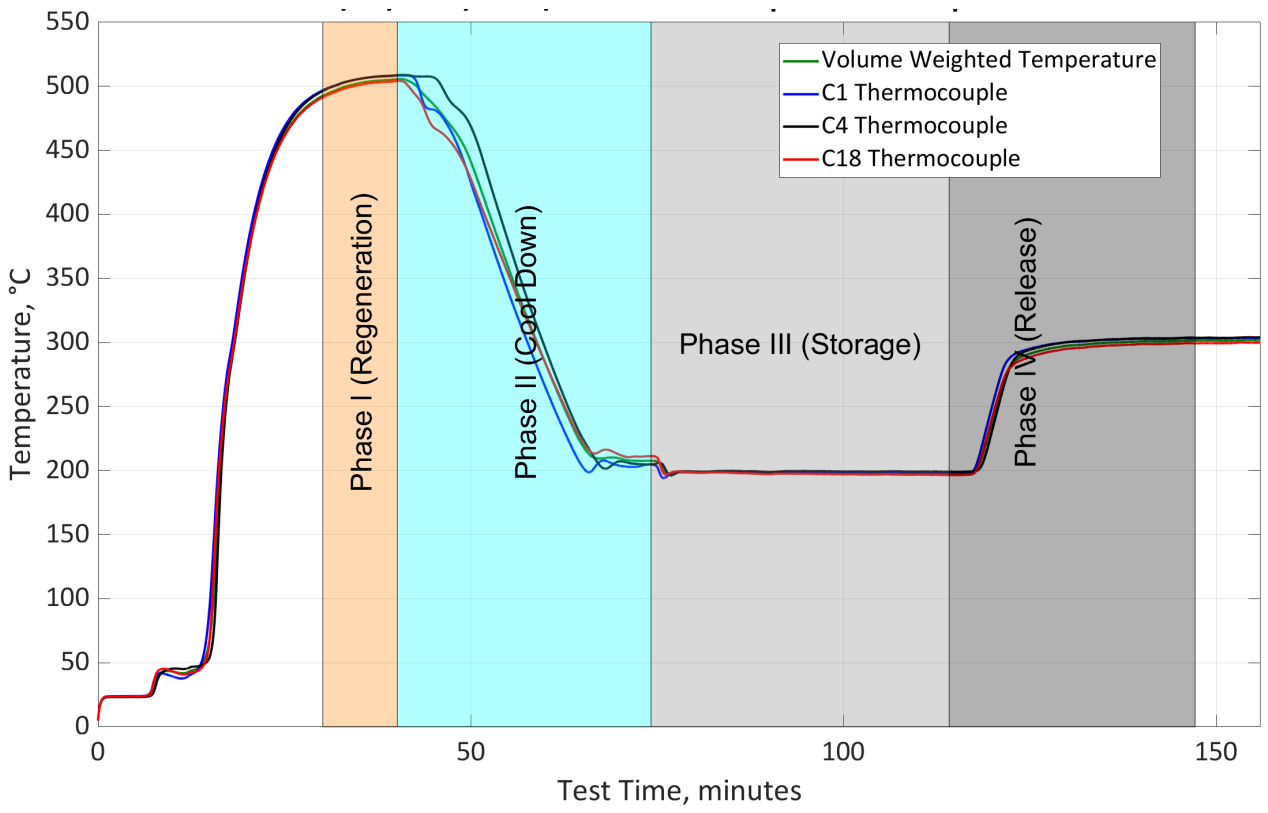

F.2 Control Test dCSC ${ }^{\text {TM }}$ Temperature during Test Phases I-IV 


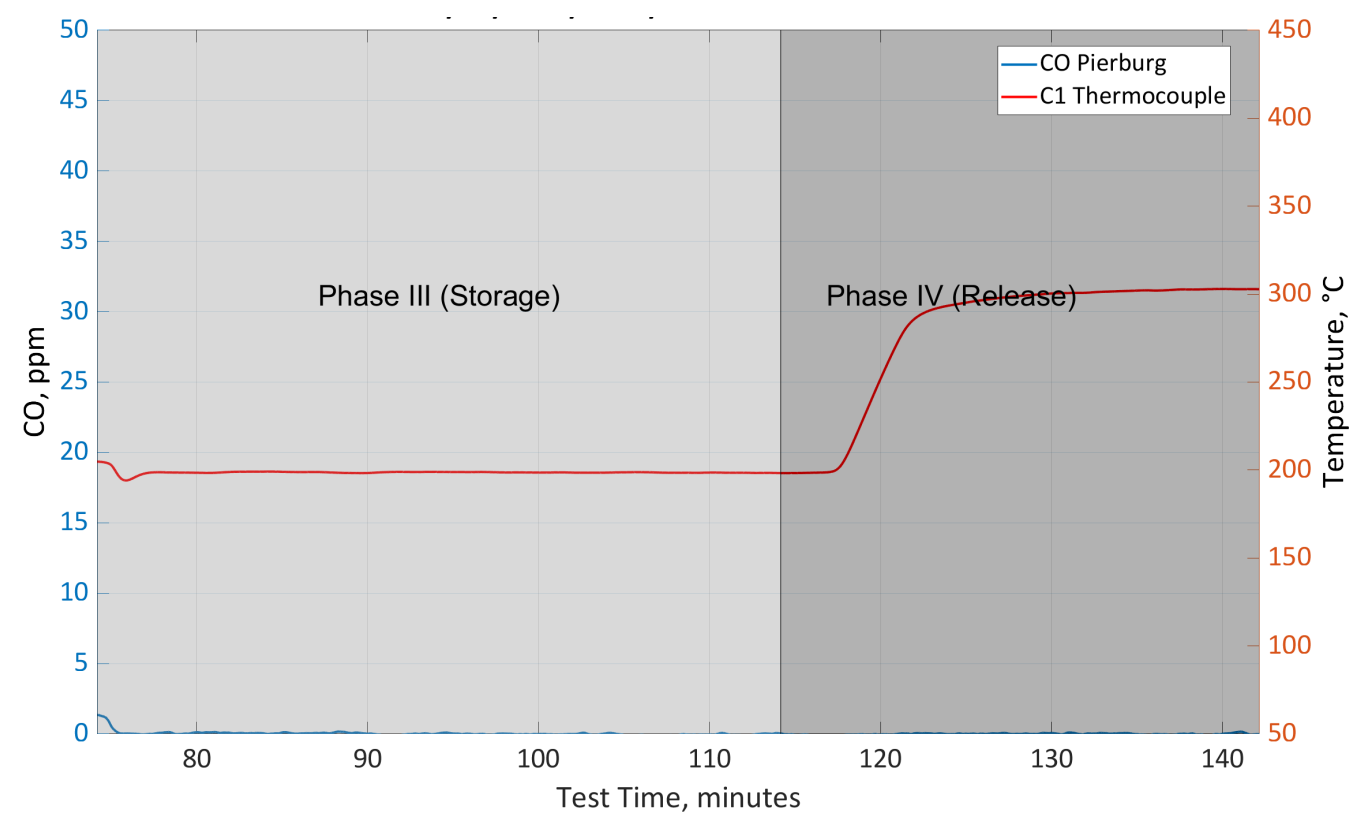

F.3 Downstream dCSCTM CO Concentration during a $200{ }^{\circ} \mathrm{C}$ Test Phase III and $300{ }^{\circ} \mathrm{C}$ Phase IV, at Engine Condition 1

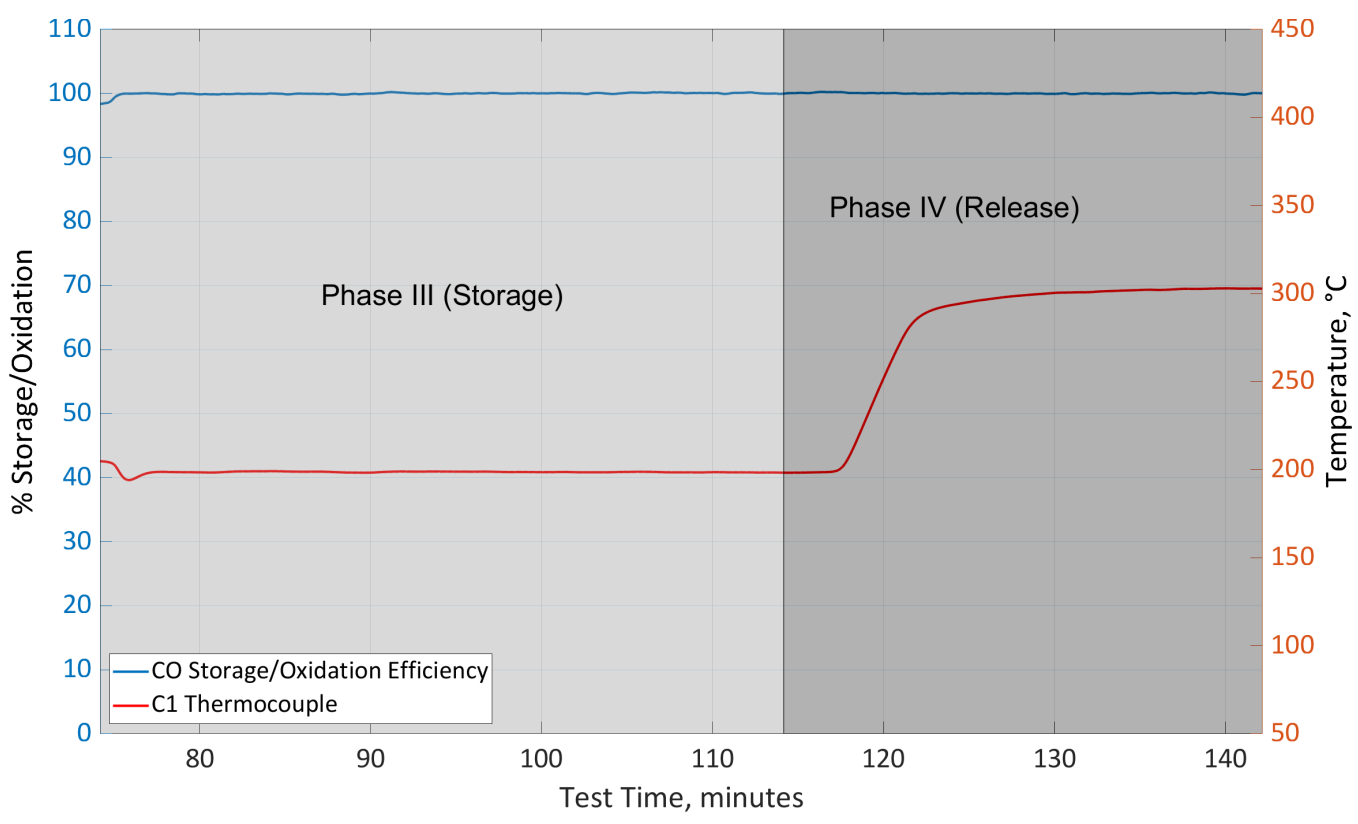

F.4 dCSC ${ }^{\text {TM }}$ CO Storage/Oxidation Efficiency during a $200{ }^{\circ} \mathrm{C}$ Test Phase III and $300{ }^{\circ} \mathrm{C}$ Phase IV, at Engine Condition 1 


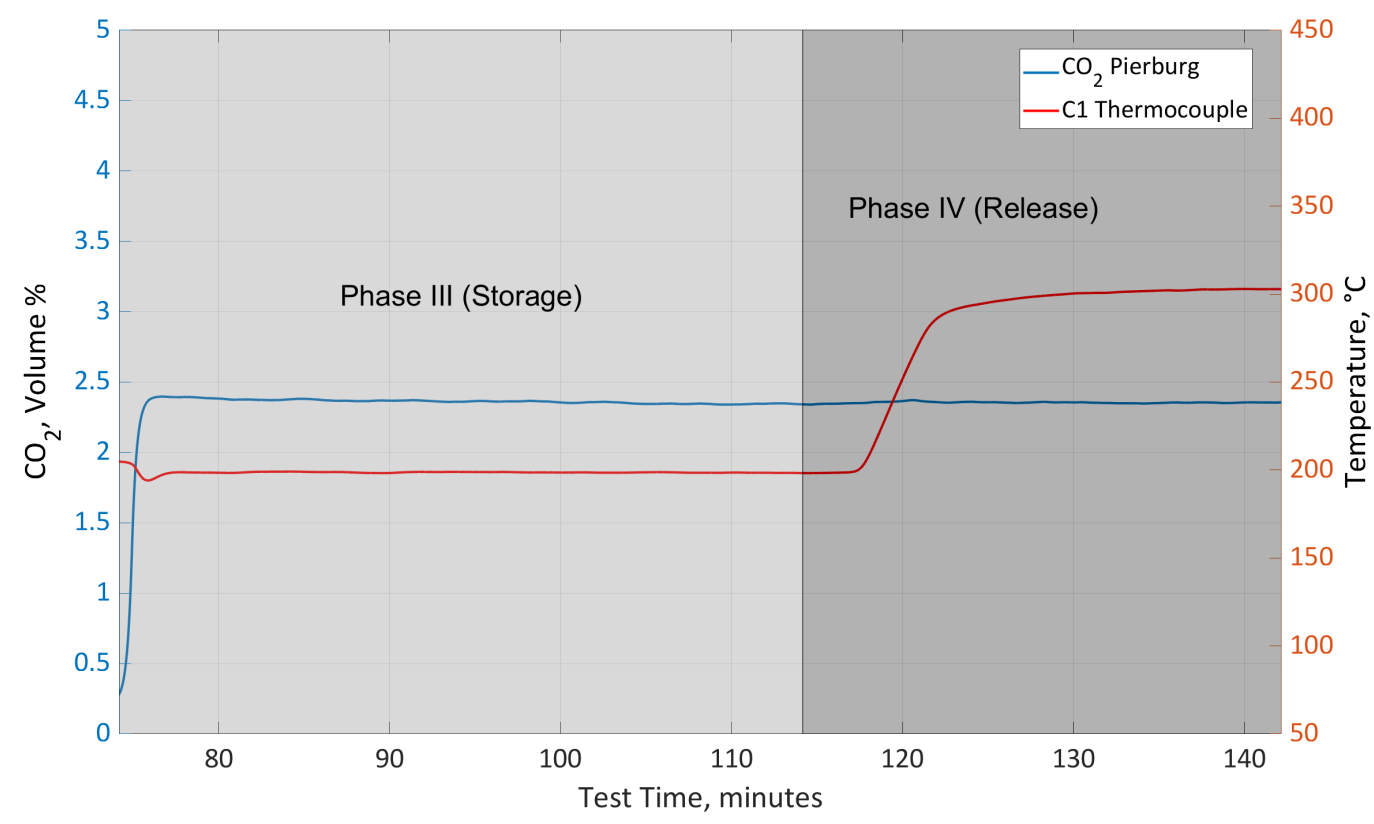

F.5 Downstream dCSC ${ }^{\mathrm{TM}} \mathrm{CO}_{2}$ Concentration during a $200{ }^{\circ} \mathrm{C}$ Test Phase III and $300{ }^{\circ} \mathrm{C}$ Phase IV, at Engine Condition 1

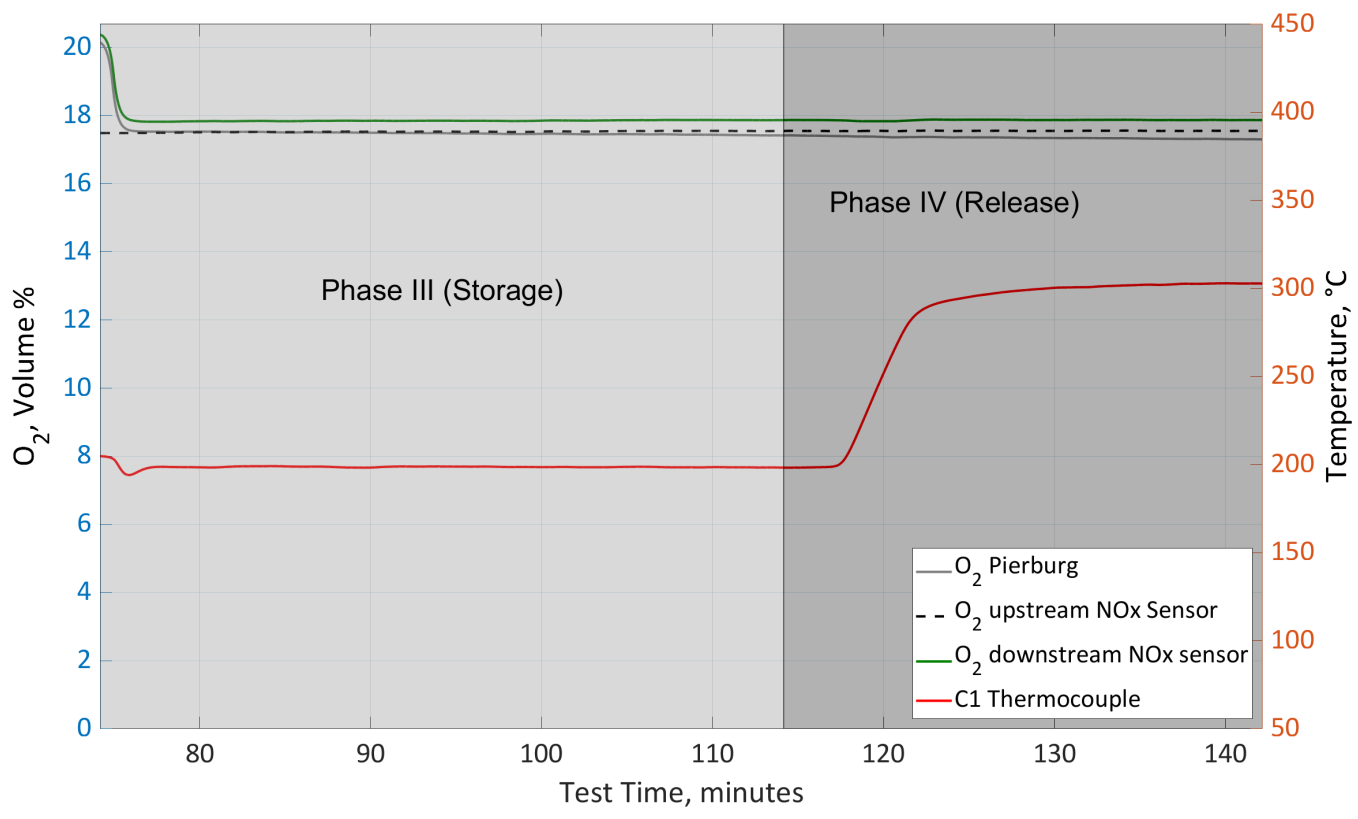

F.6 Downstream dCSC ${ }^{\mathrm{TM}} \mathrm{CO}_{2}$ Concentration during a $200{ }^{\circ} \mathrm{C}$ Test Phase III and $300{ }^{\circ} \mathrm{C}$ Phase IV, at Engine Condition 1 


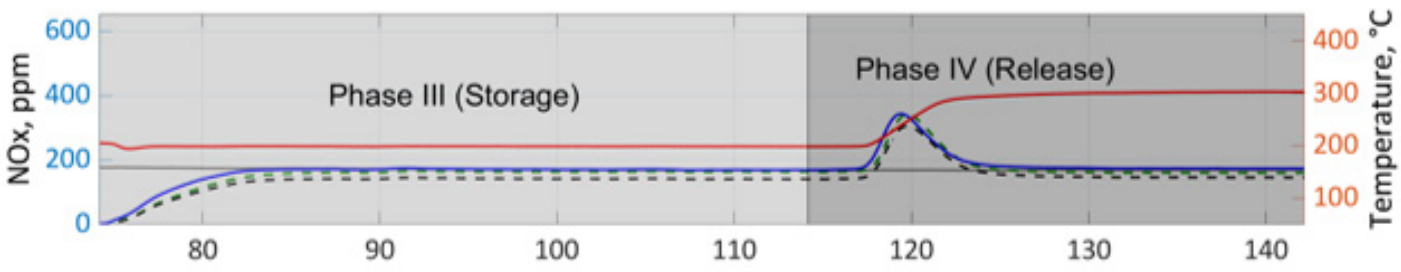

- NOx Sensor Upstream - - NOx Sensor Downstream — NOx Pierburg - - NOx Cambustion — C1 Thermocouple

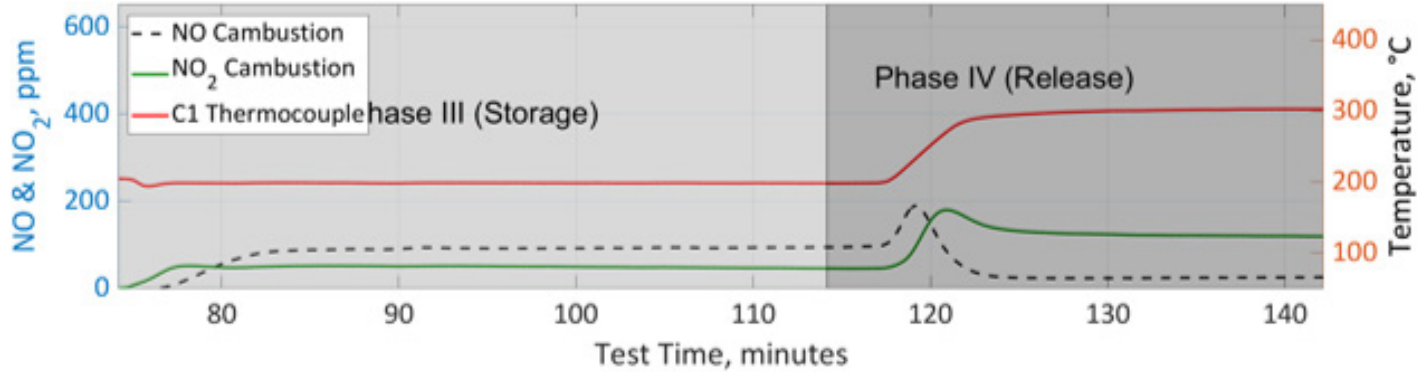

F.7 Downstream dCSC ${ }^{\mathrm{TM}} \mathrm{NO}, \mathrm{NO}_{2}$, and NOx Concentrations during a $200{ }^{\circ} \mathrm{C}$ Test Phase

III and $300{ }^{\circ} \mathrm{C}$ Phase IV, at Engine Condition 1

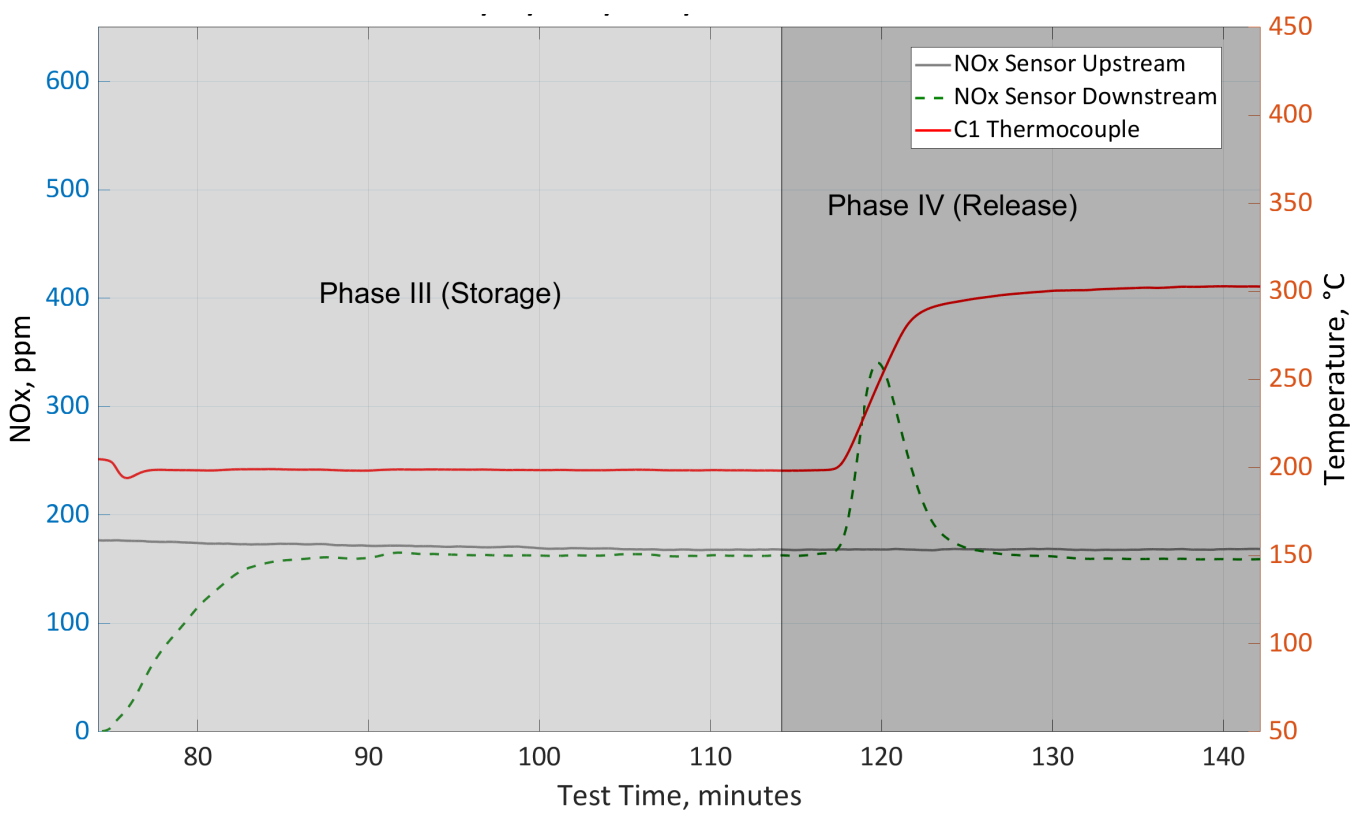

F.8 Downstream dCSCTM NOx Sensor Concentrations during a $200{ }^{\circ} \mathrm{C}$ Test Phase III and $300{ }^{\circ} \mathrm{C}$ Phase IV, at Engine Condition 1 


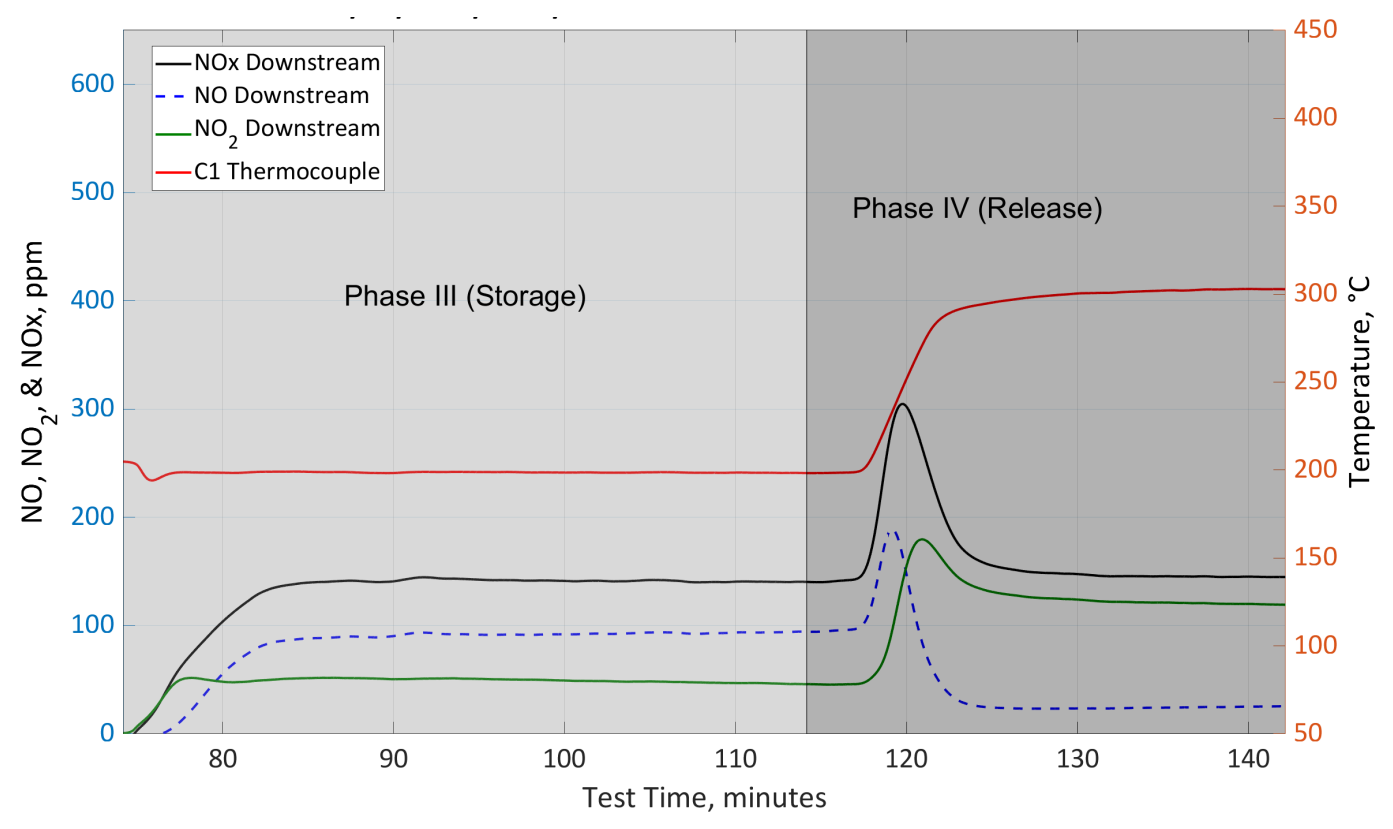

F.9 Downstream dCSC ${ }^{\text {TM }}$ Cambustion CLD NO, $\mathrm{NO}_{2}$, and $\mathrm{NOx}$ Concentrations during a $200{ }^{\circ} \mathrm{C}$ Test Phase III and $300^{\circ} \mathrm{C}$ Phase IV, at Engine Condition 1

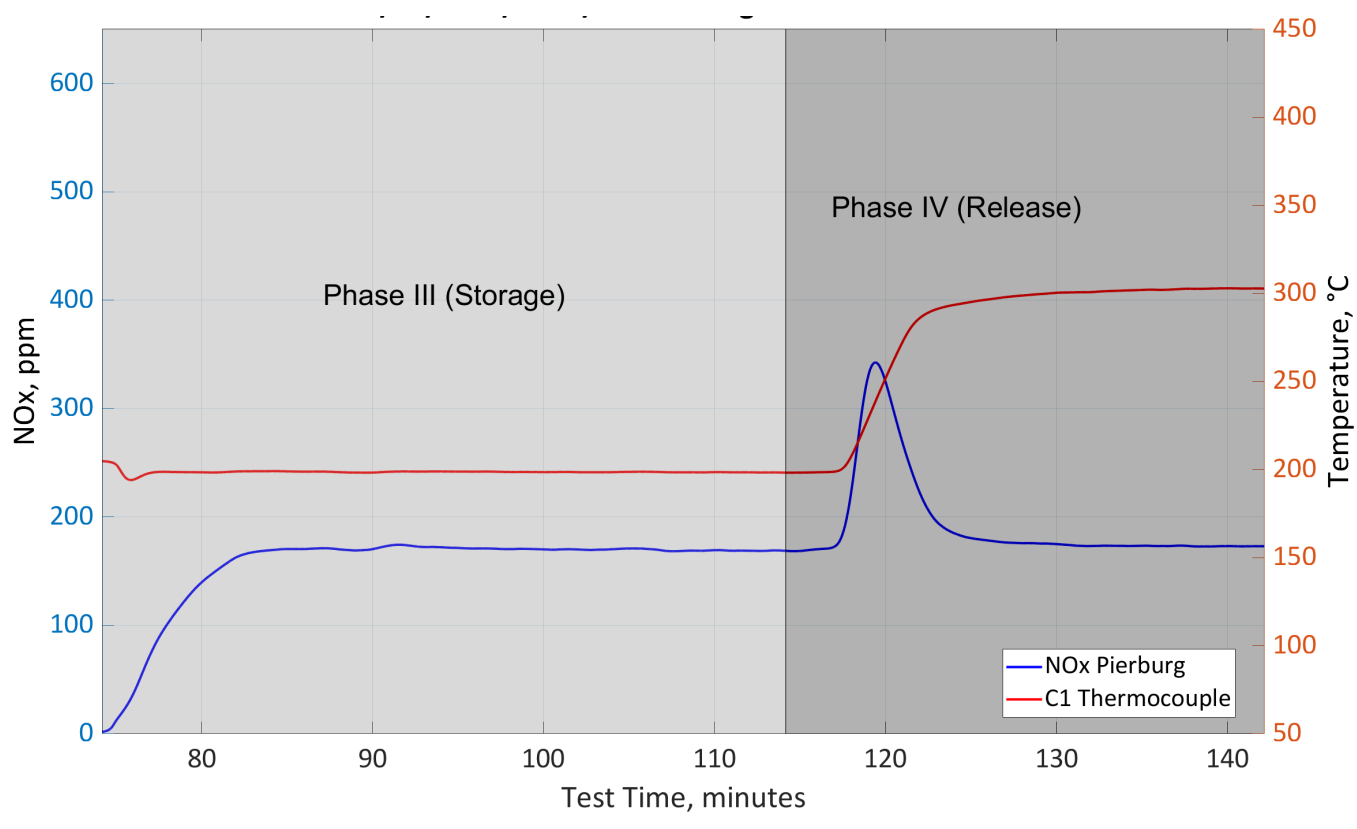

F.10 Downstream dCSC ${ }^{\mathrm{TM}}$ NOx Concentrations during a $200{ }^{\circ} \mathrm{C}$ Test Phase III and 300 ${ }^{\circ} \mathrm{C}$ Phase IV, at Engine Condition 1 


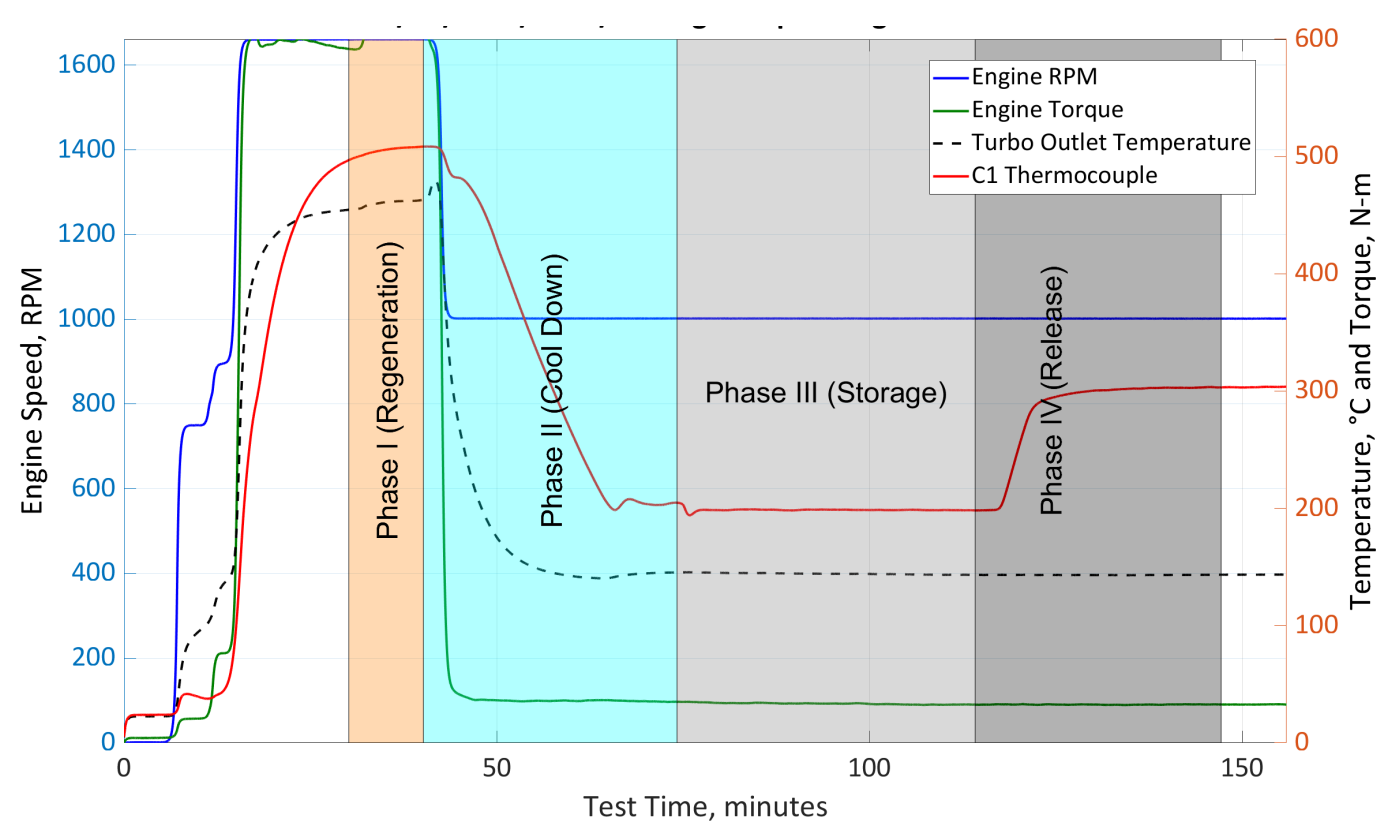

F.11 Engine Load and Speed, Turbo Outlet Temperature, and C1 Thermocouple Temperature during a $200{ }^{\circ} \mathrm{C}$ Test Phase III and $300{ }^{\circ} \mathrm{C}$ Phase IV, at Engine Condition 1

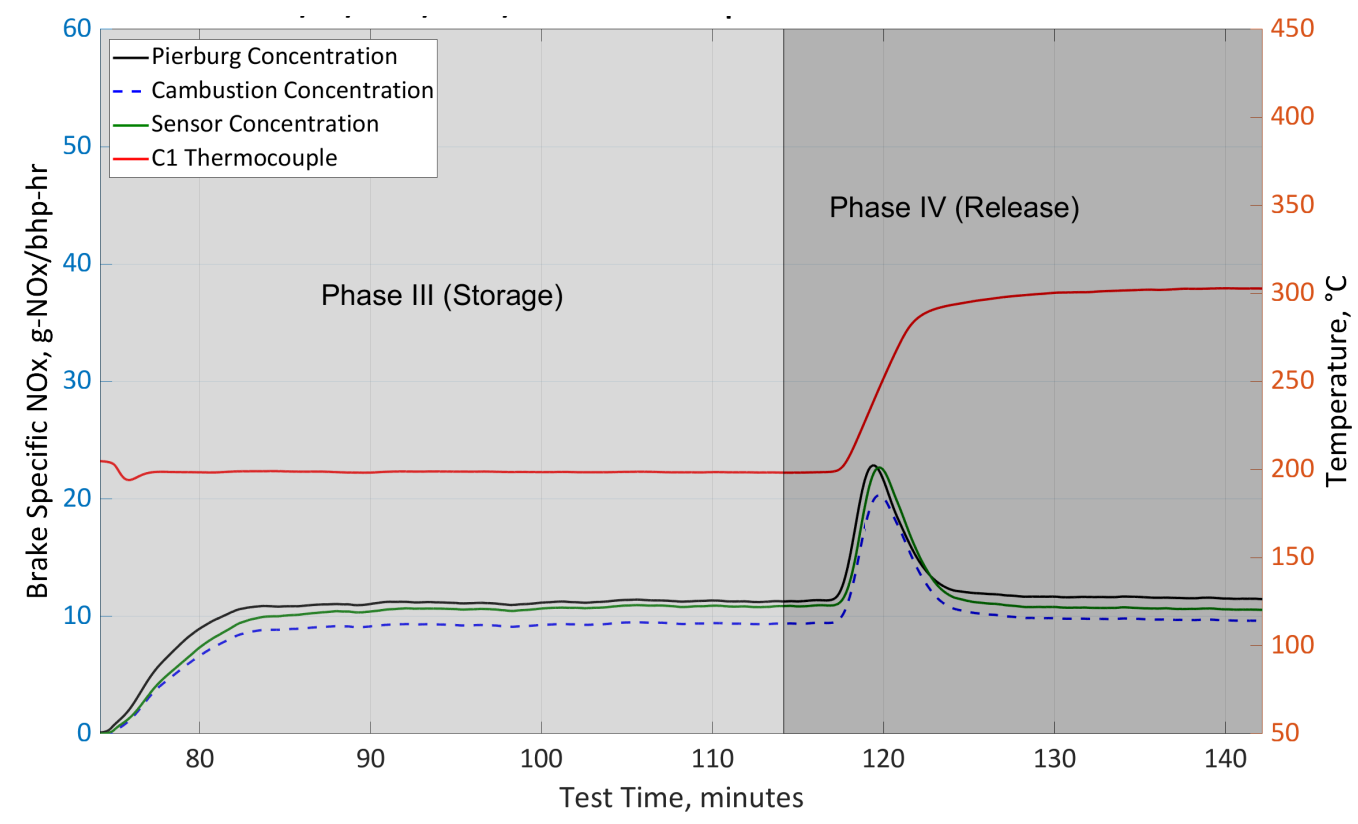

F.12 Downstream dCSC ${ }^{\mathrm{TM}}$ Brake Specific NOx during a $200{ }^{\circ} \mathrm{C}$ Test Phase III and 300 ${ }^{\circ} \mathrm{C}$ Phase IV, at Engine Condition 1 


\section{Appendix G. Control Plots}

Appendix $\mathrm{G}$ shows control plots for the various lab instrumentation and testing conditions monitored during testing. Test run order refers to the order in which the tests were run. Certain engine and test cell conditions were measured with lab instrumentation and are also measured with sensors on the engine or calculated by the Cummins Calterm calibration tool. The values measured with lab instrumentation were logged with NI LabVIEW DAQ hardware and software. These values are referred to in the plot legend as LabVIEW. The values measured with sensors on the engine or calculated by Calterm are referred to in the plot legend as Calterm.

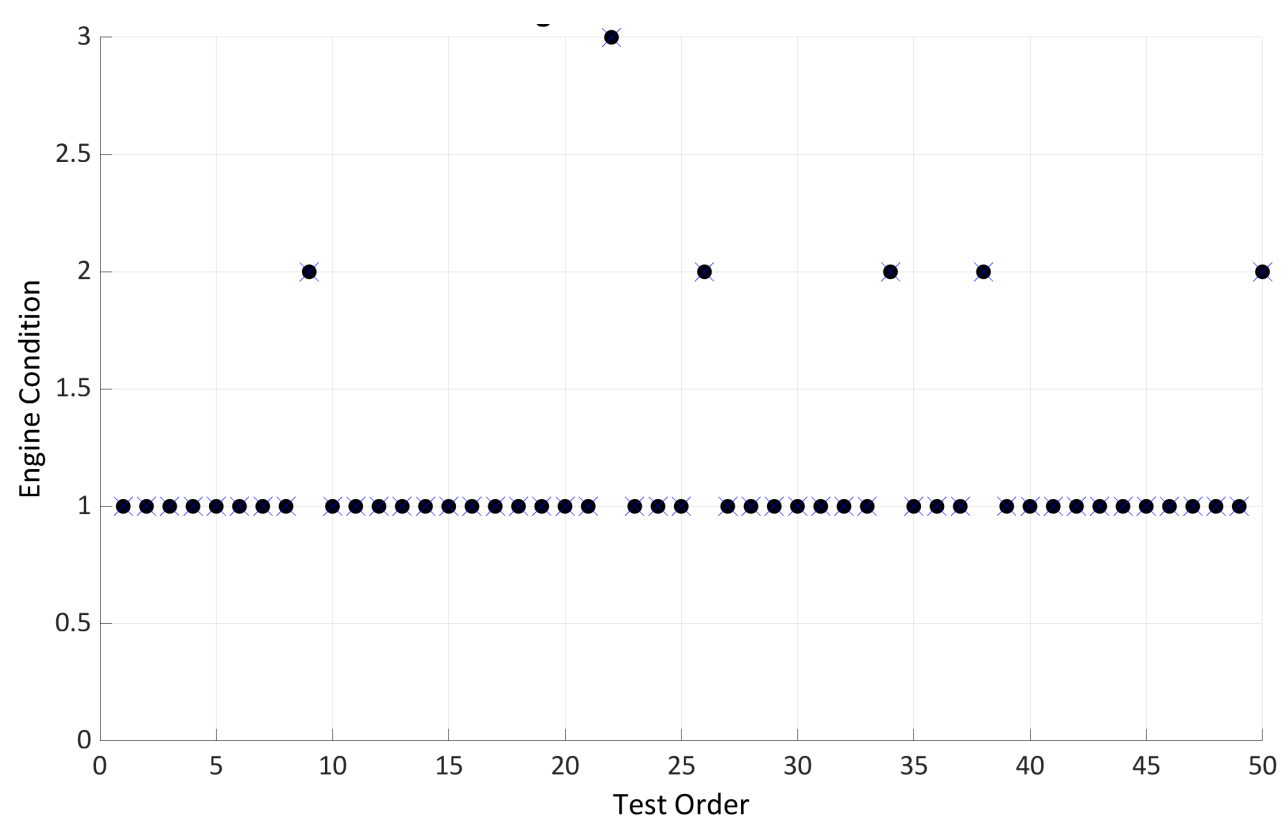

G.1 Engine Condition vs. Test Order 


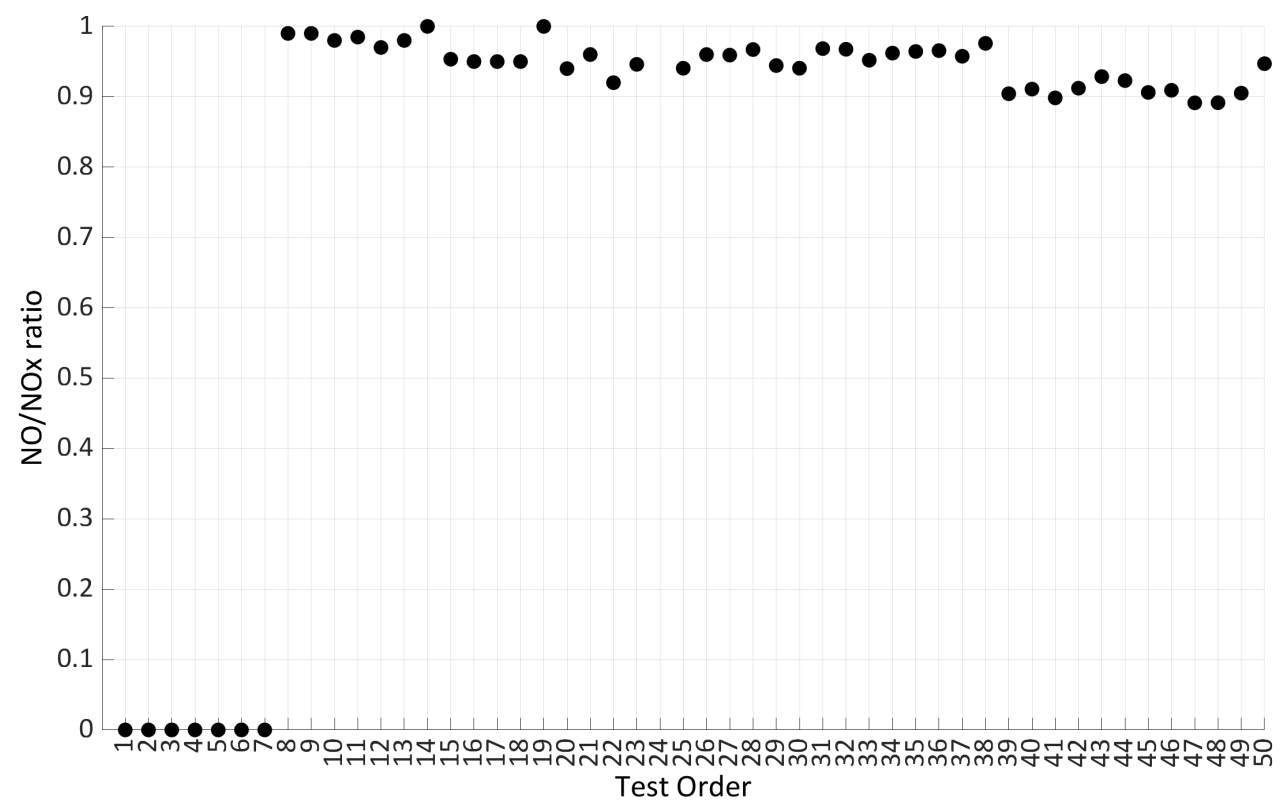

G.2 Upstream dCSC ${ }^{\text {TM }}$ NO/NOx Ratio vs. Test Order

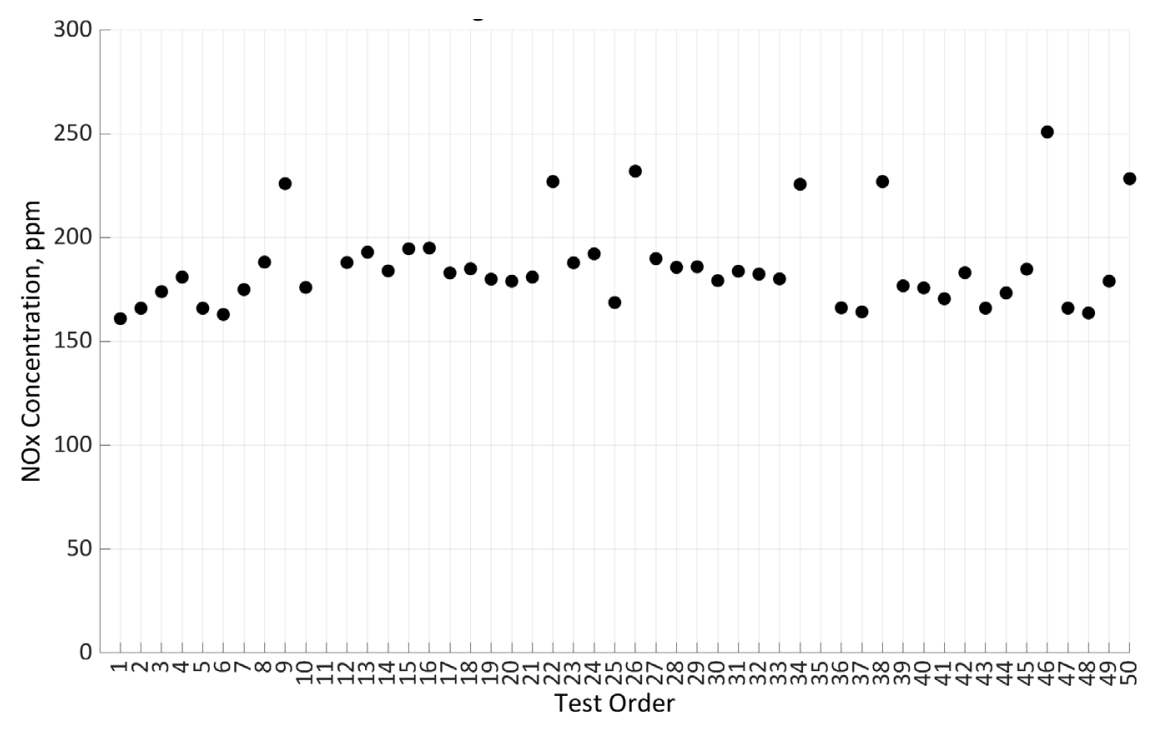

G.3 Upstream dCSC ${ }^{\text {TM }}$ NOx Sensor NOx Concentration vs. Test Order 


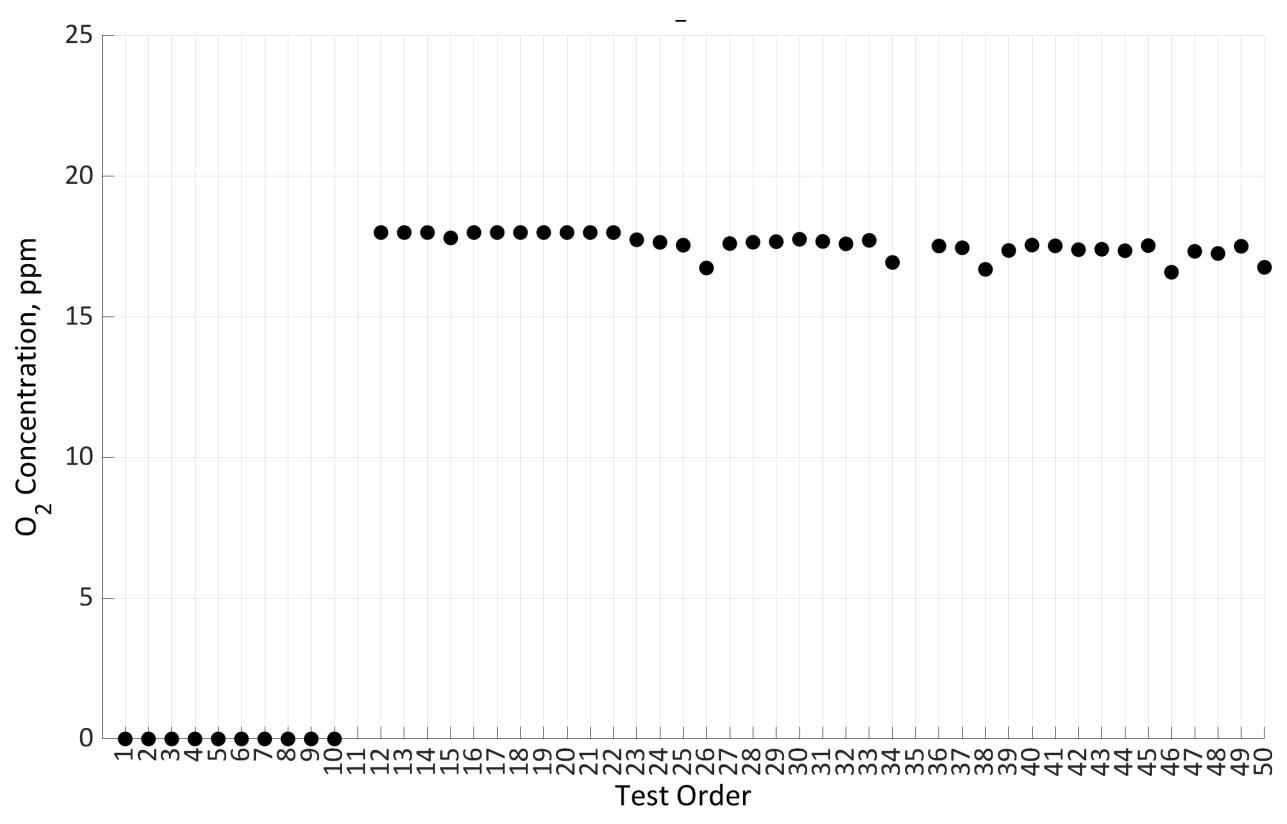

G.4 Upstream dCSCTM NOx Sensor $\mathrm{O}_{2}$ Concentration vs. Test Order

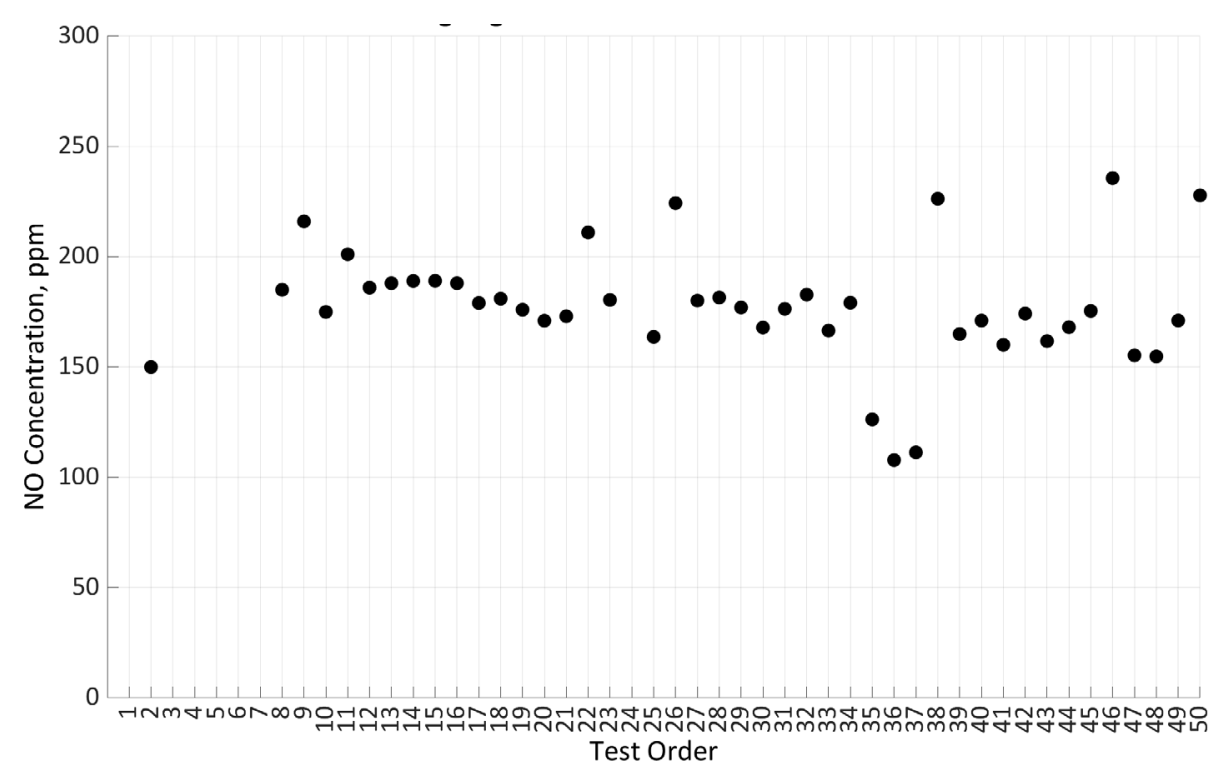

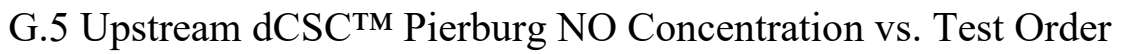




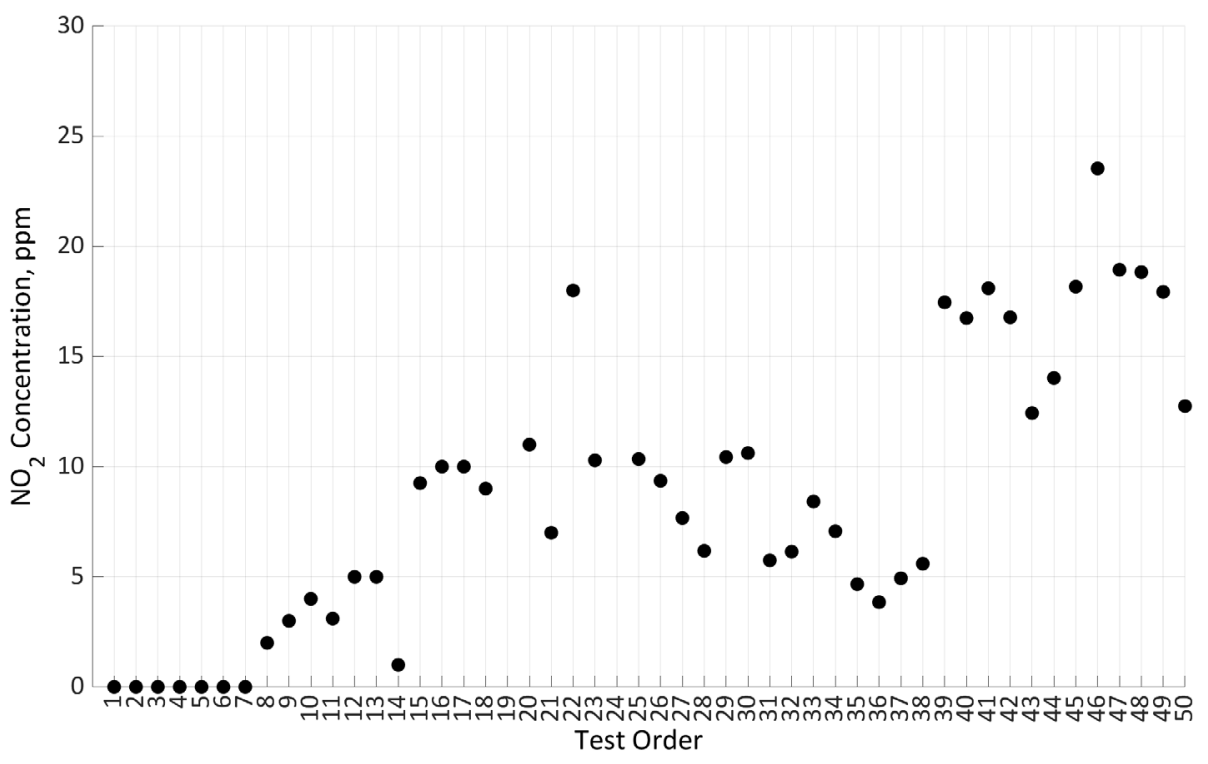

G.6 Upstream dCSC ${ }^{\mathrm{TM}}$ Pierburg $\mathrm{NO}_{2}$ Concentration vs. Test Order

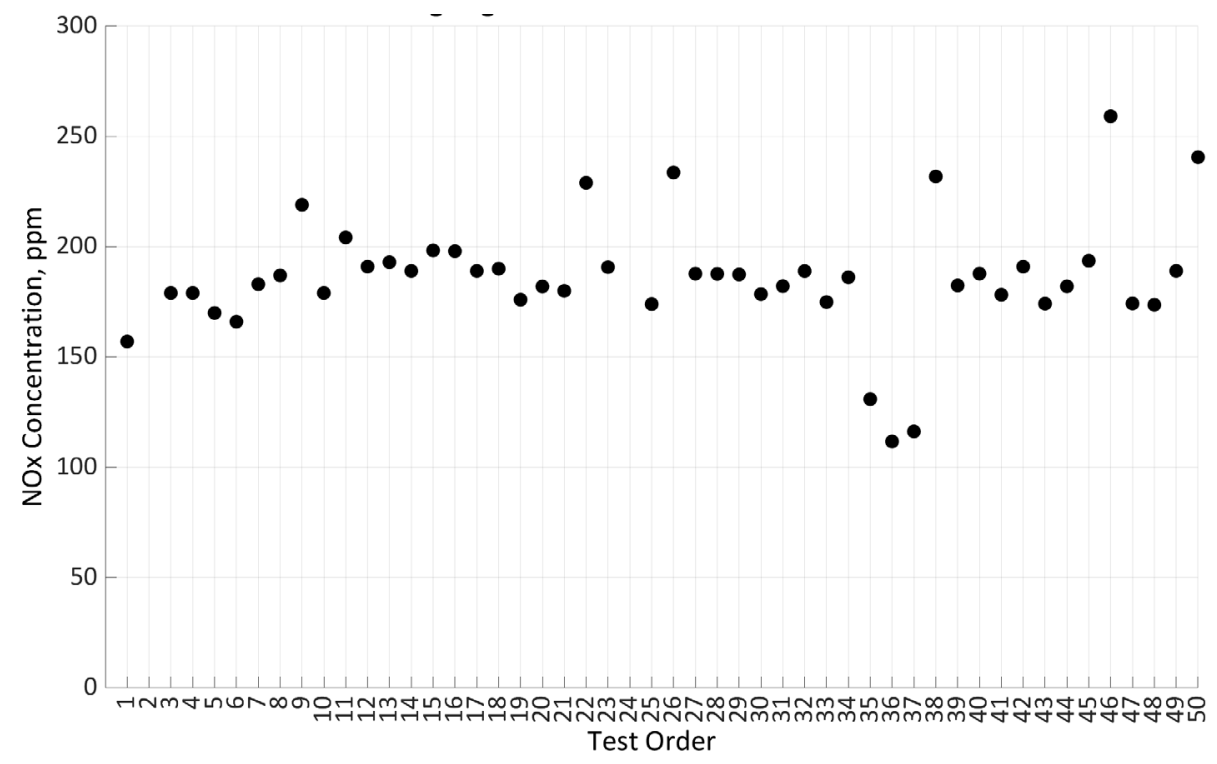

G.7 Upstream dCSC ${ }^{\text {TM }}$ Pierburg NOx Concentration vs. Test Order 


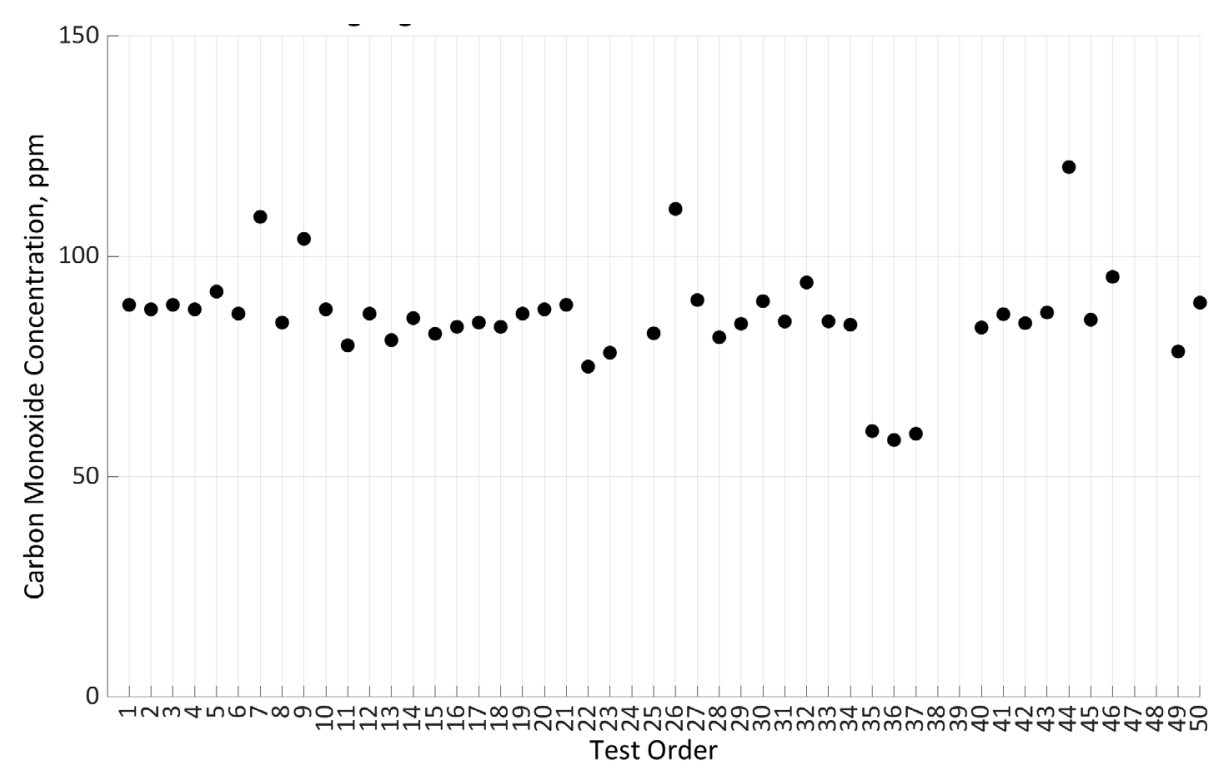

G.8 Upstream dCSC ${ }^{\text {TM }}$ Pierburg CO Concentration vs. Test Order

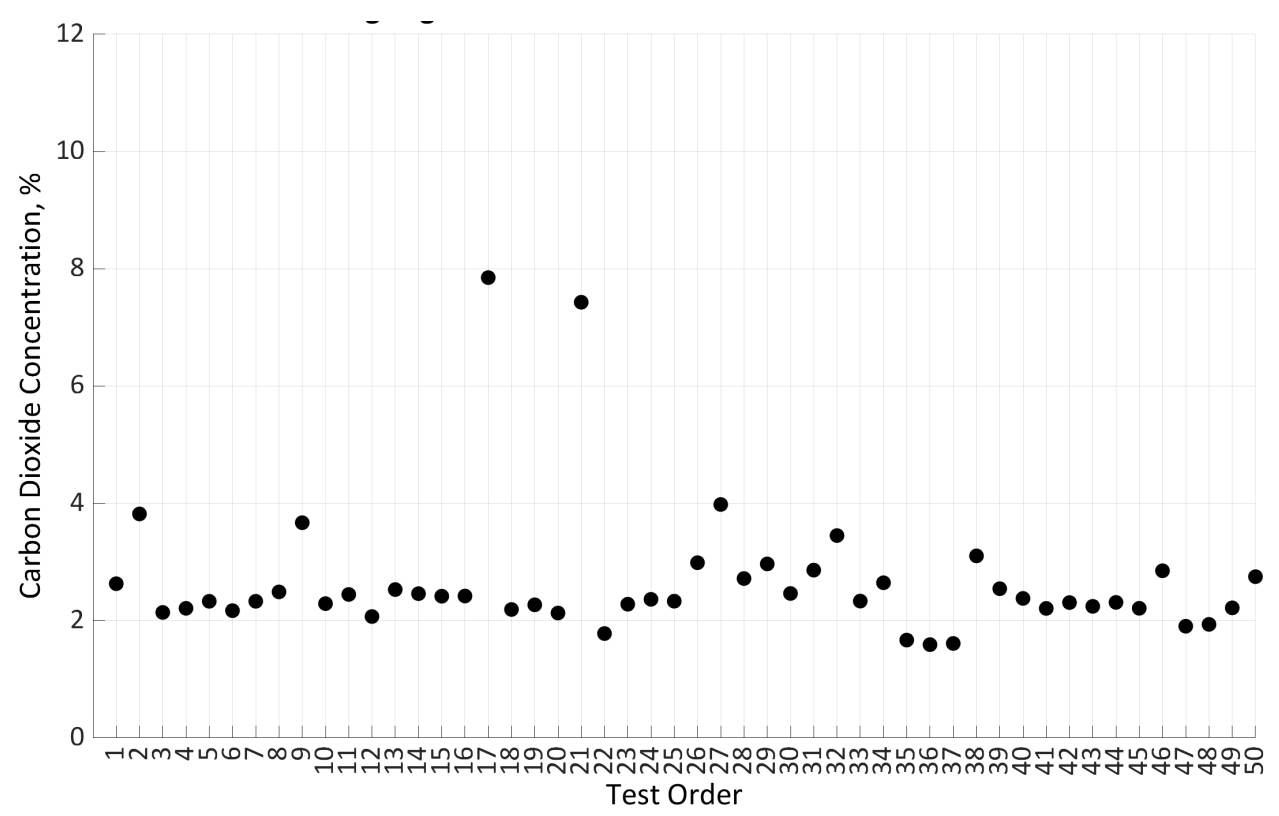

G.9 Upstream dCSC ${ }^{\mathrm{TM}}$ Pierburg $\mathrm{CO}_{2}$ Concentration vs. Test Order 


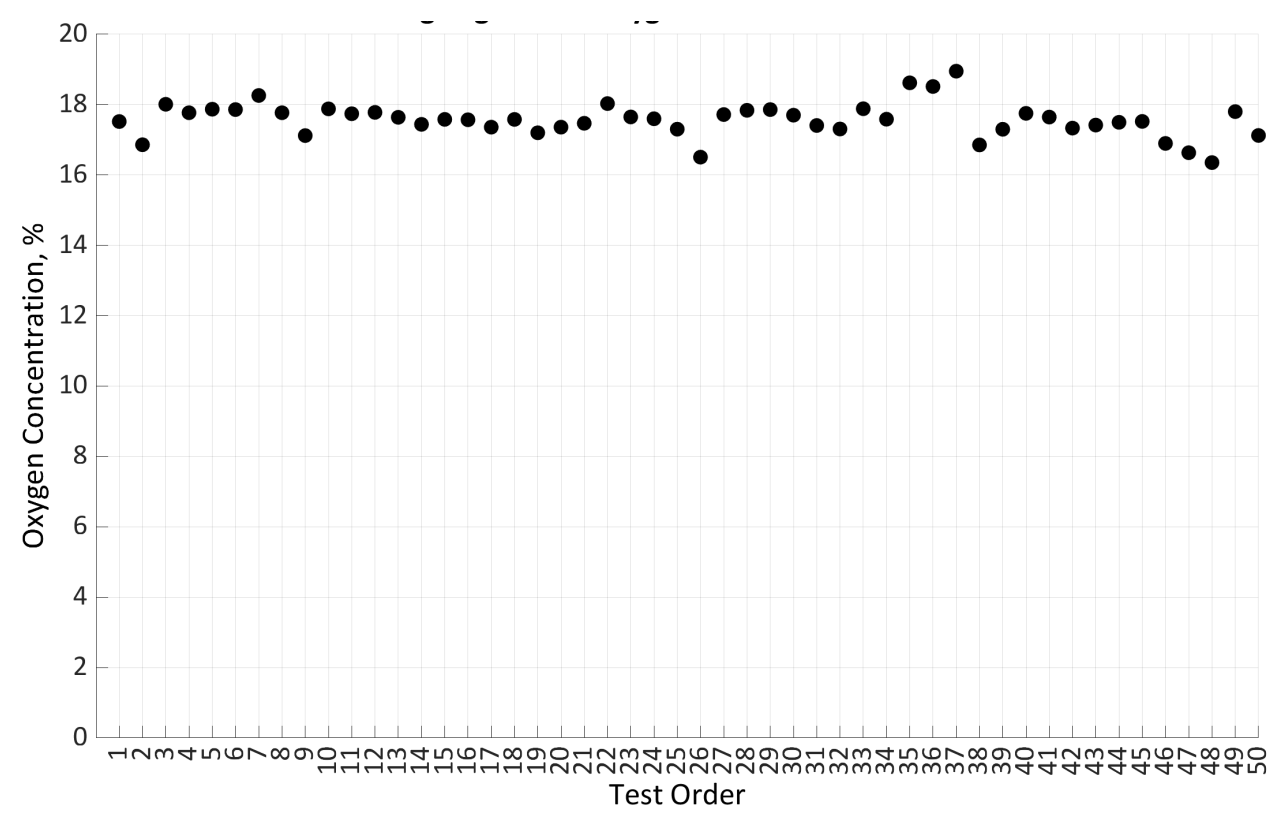

G.10 Upstream dCSC ${ }^{\text {TM }}$ Pierburg $\mathrm{O}_{2}$ Concentration vs. Test Order

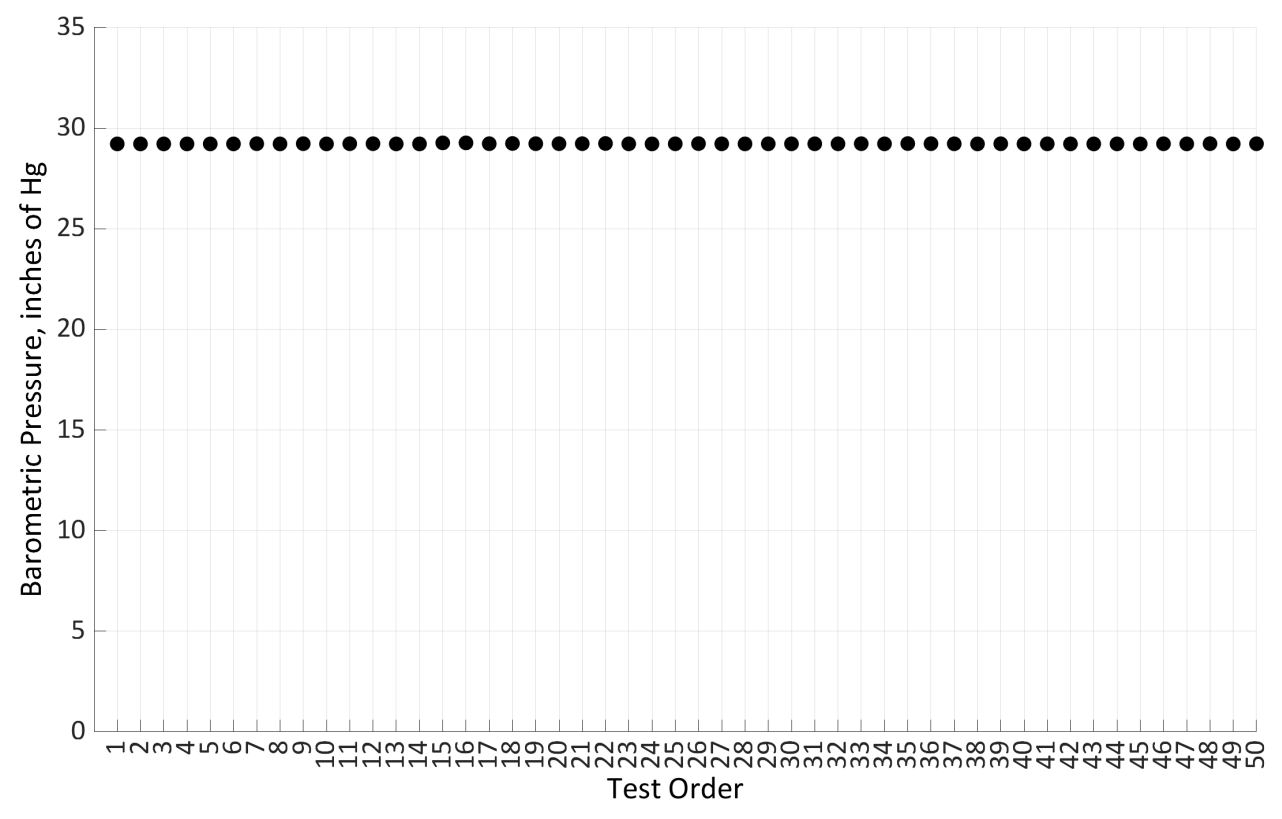

G.11 Test Cell Barometric Pressure vs. Test Order 


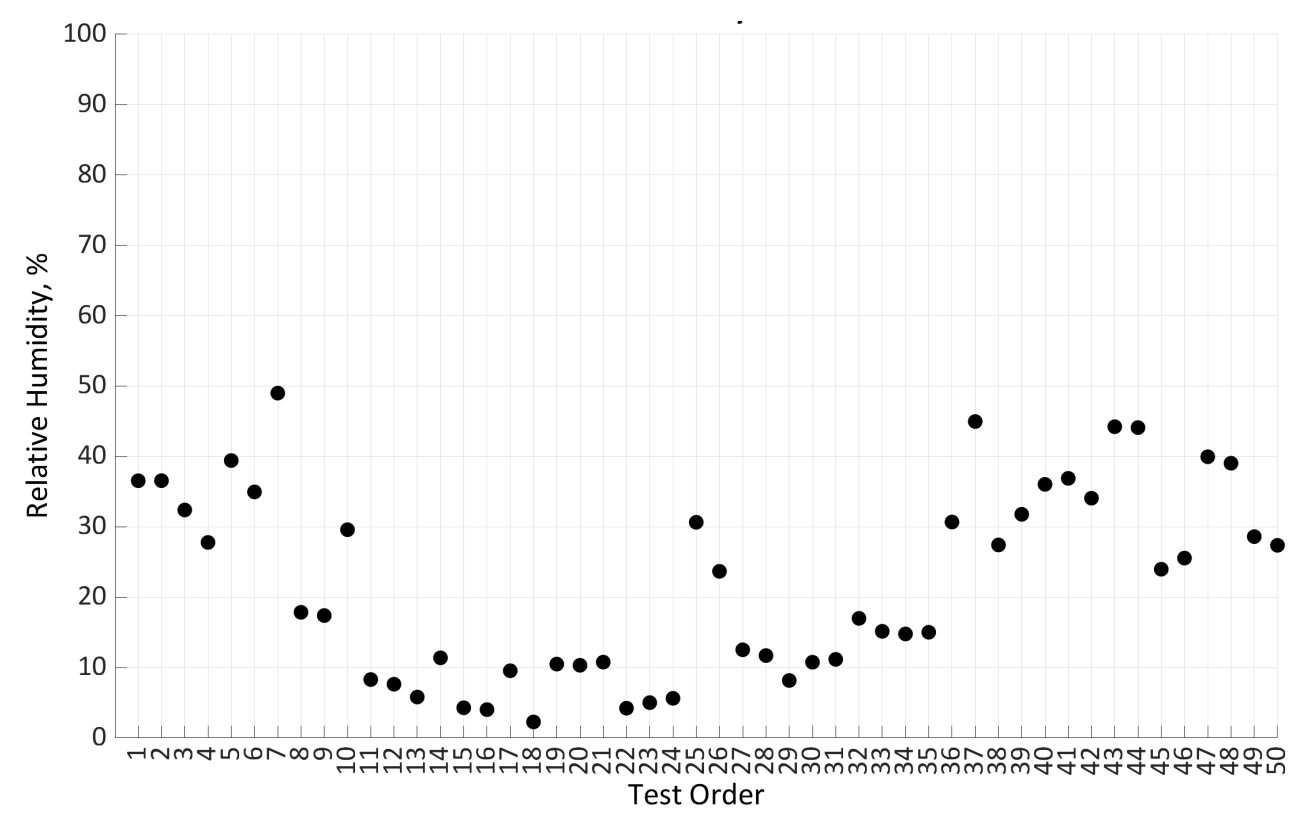

G.12 Test Cell Relative Humidity vs. Test Order

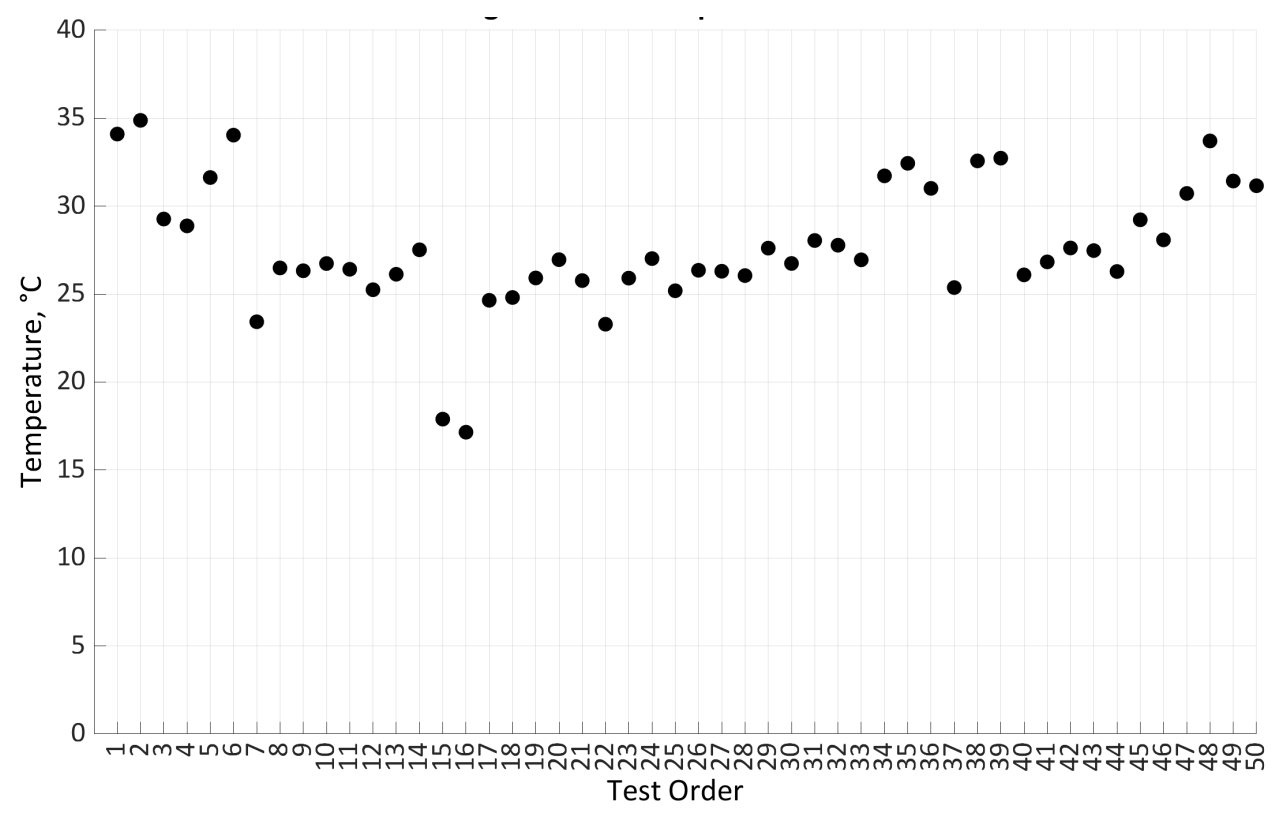

G.13 Average Test Cell Temperature during Test vs. Test Order 


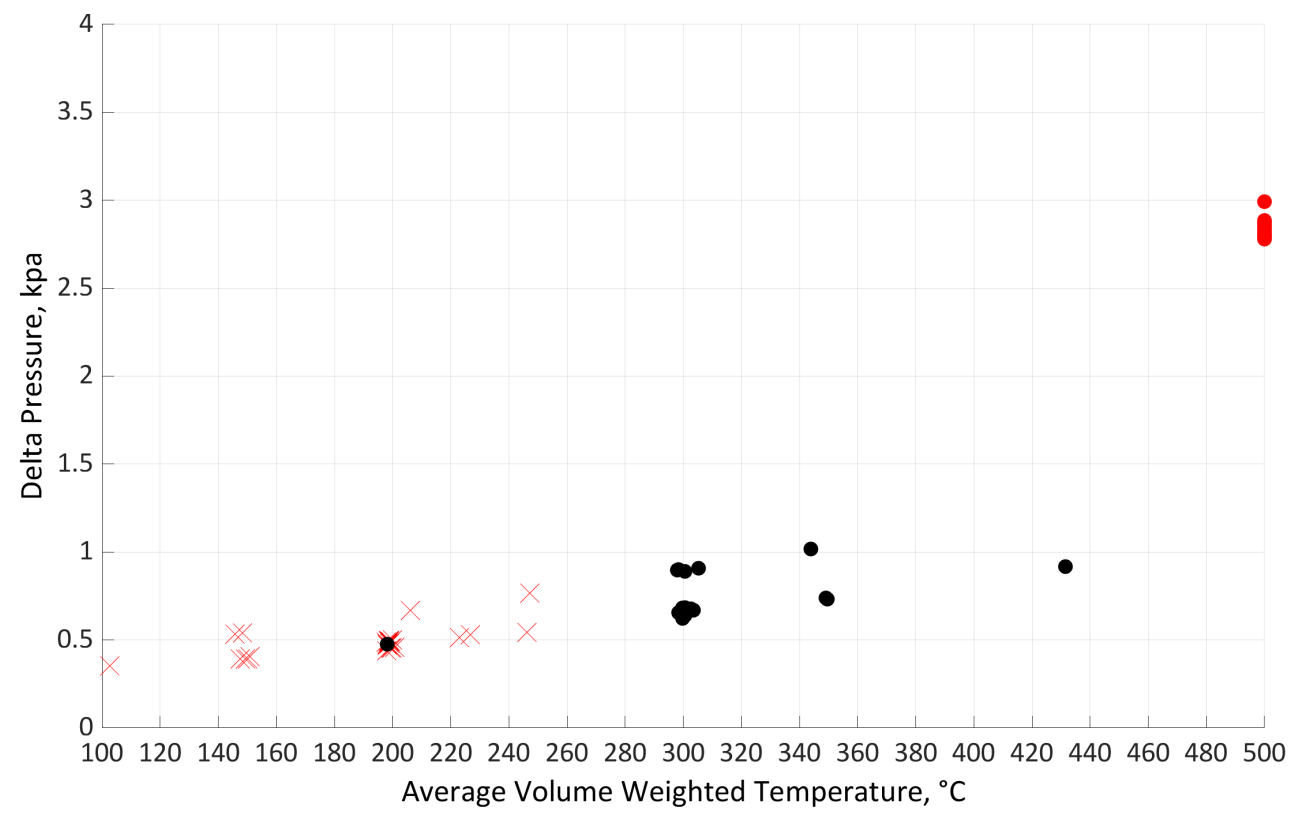

G.14 dCSCTM Delta Pressure vs. Average Volume Weighted Temperature

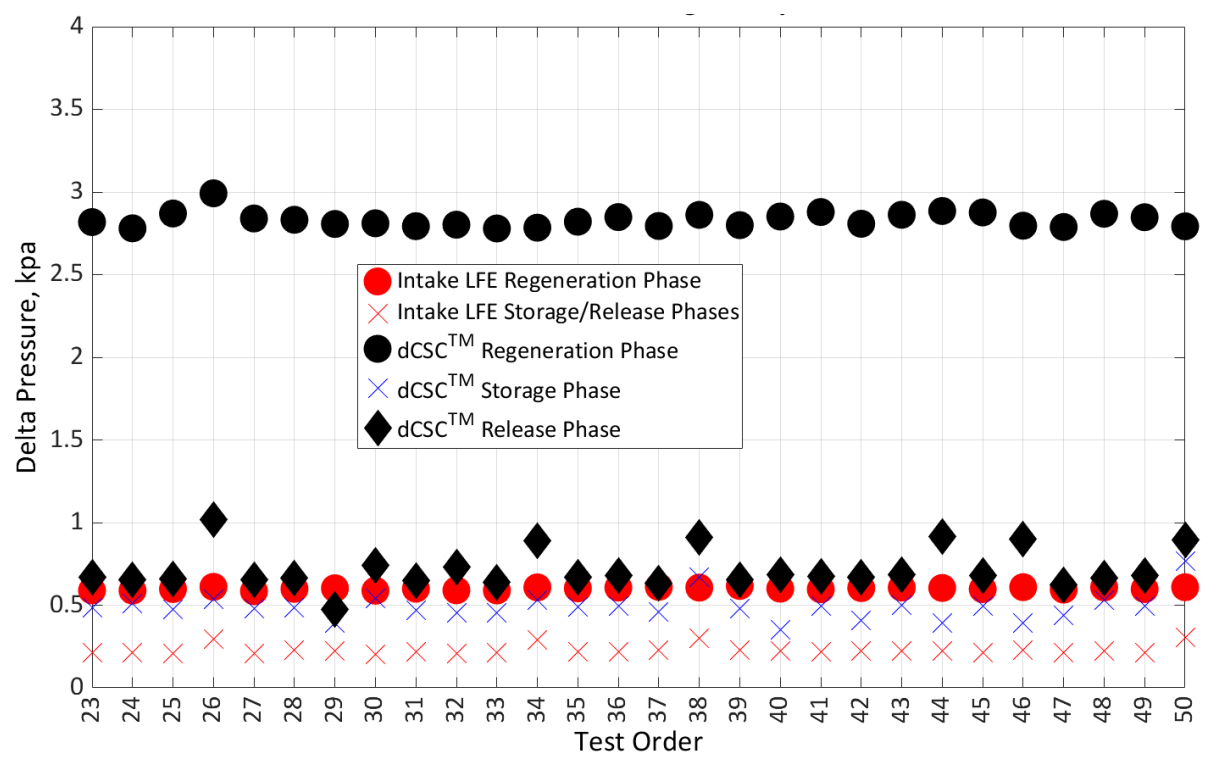

G.15 Engine Intake and dCSCTM Delta Pressures vs. Test Order 


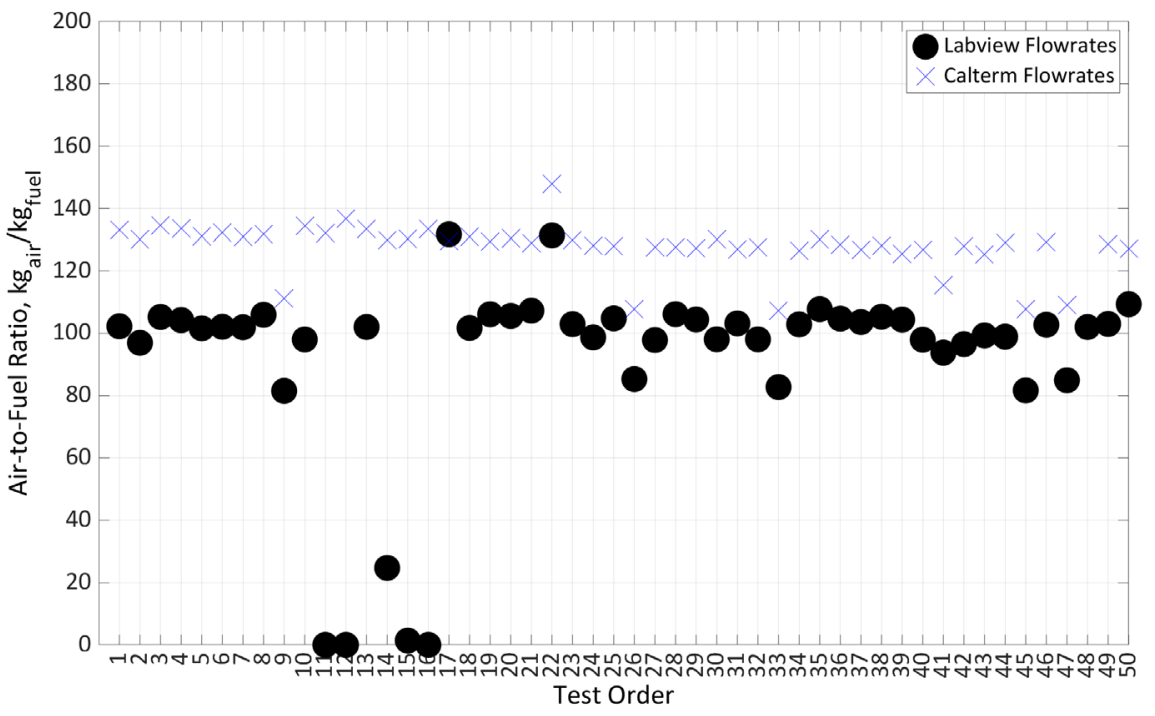

G.16 AFR Calculated from Fuel and Air Flow Rates vs. Test Order

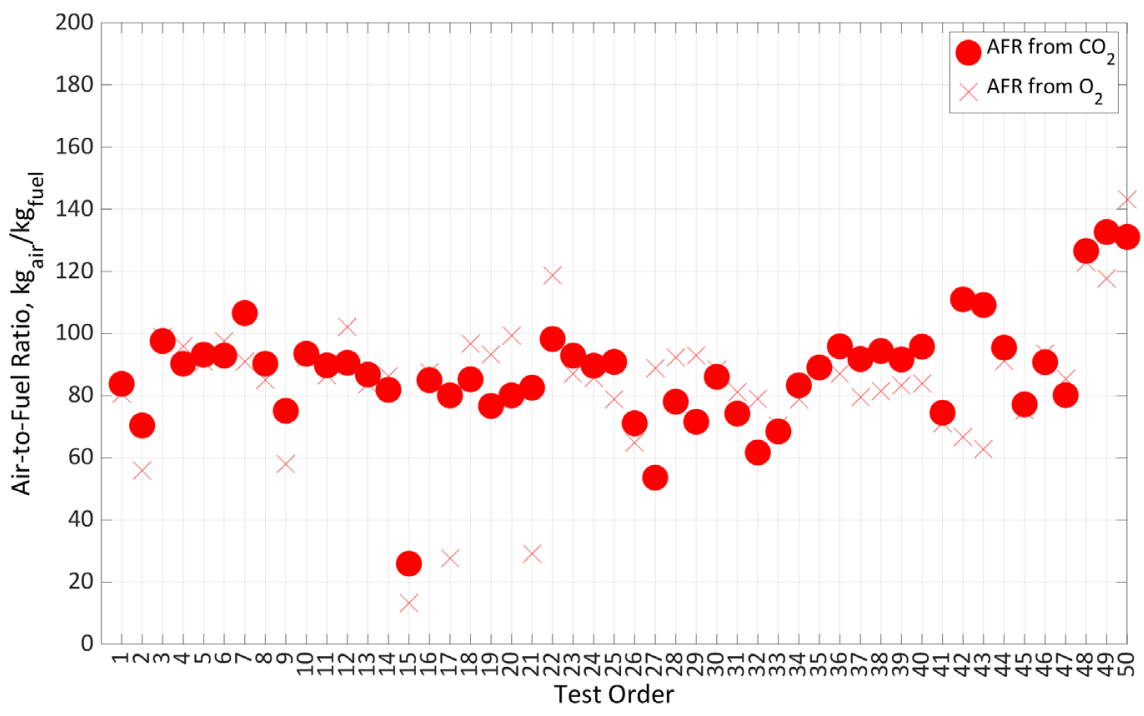

G.17 AFR Calculated from $\mathrm{O}_{2}$ and $\mathrm{CO}_{2}$ vs. Test Order 


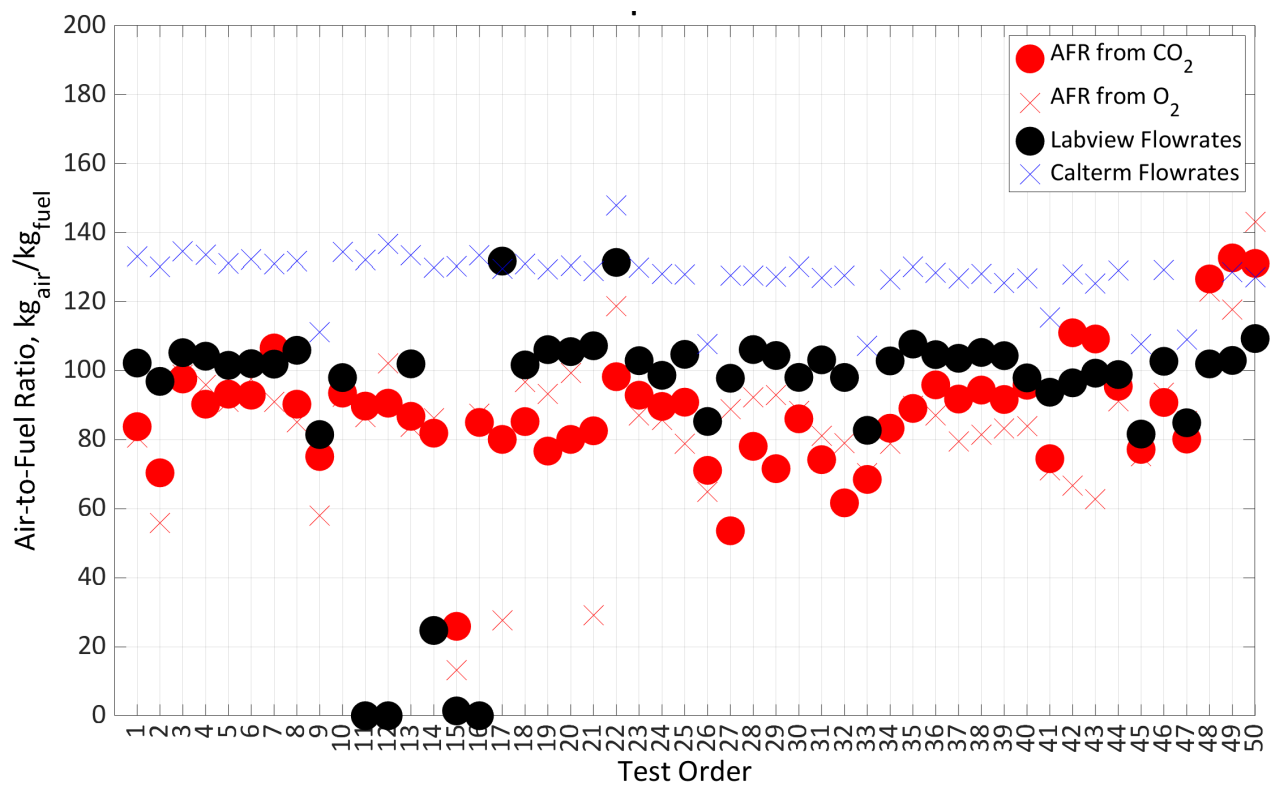

G.18 Comparison of all AFR Calculations vs. Test Order

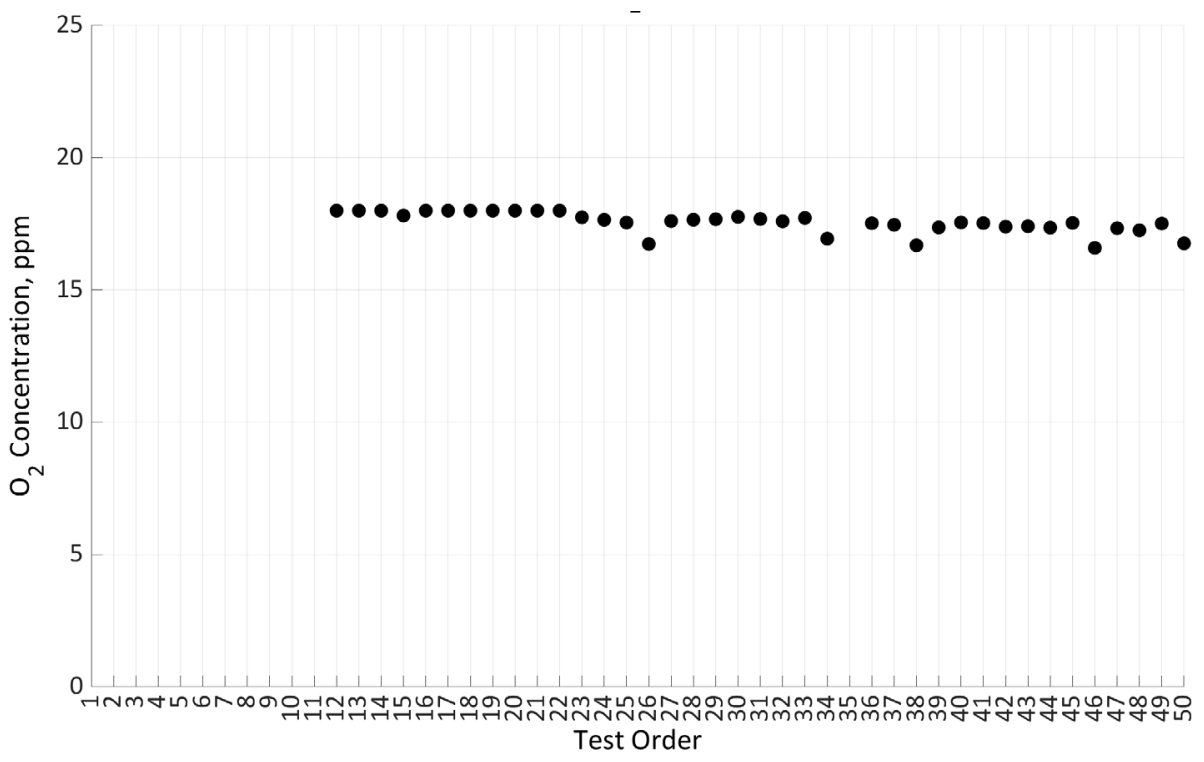

G.19 Upstream dCSC ${ }^{\text {тм }}$ NOx Sensor $\mathrm{O}_{2}$ Concentration vs. Test Order 


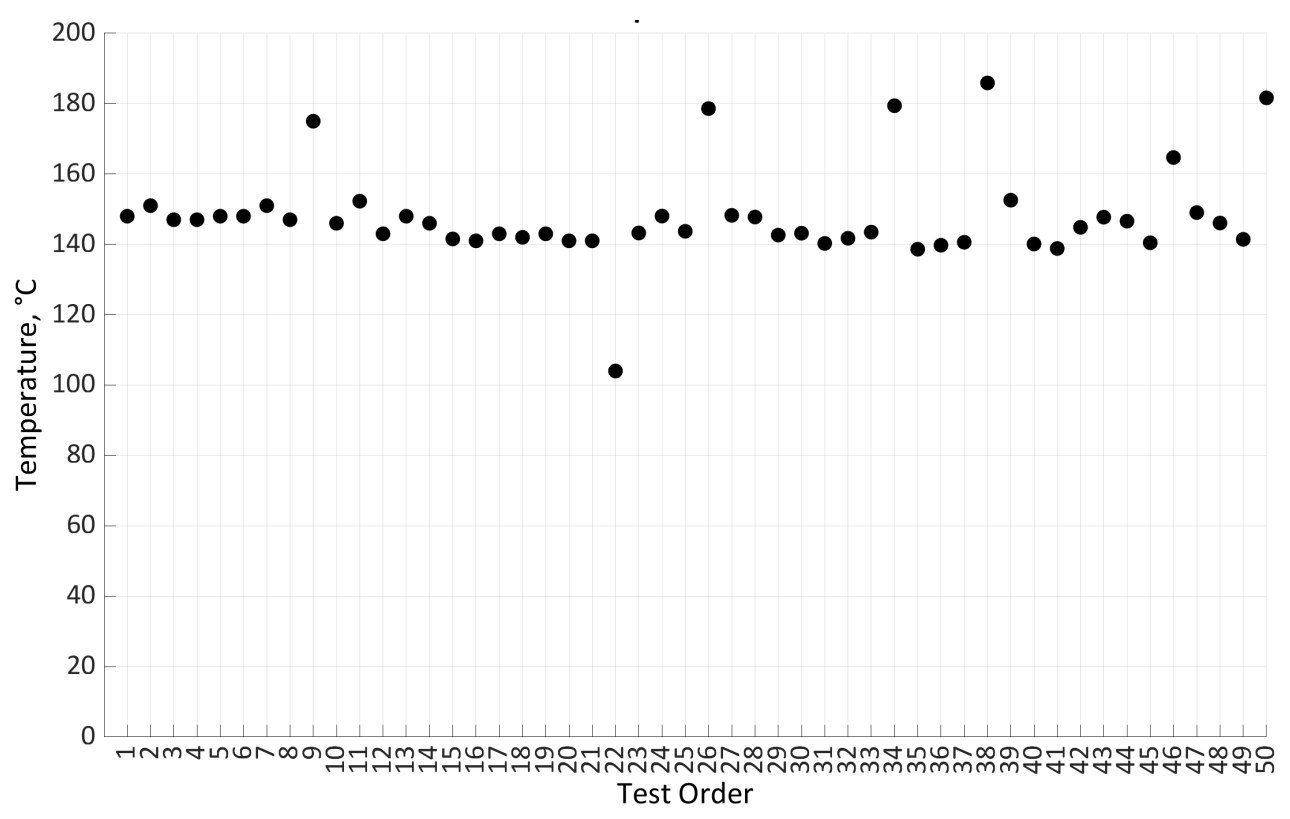

G.20 Engine Turbo Outlet Temperature vs. Test Order

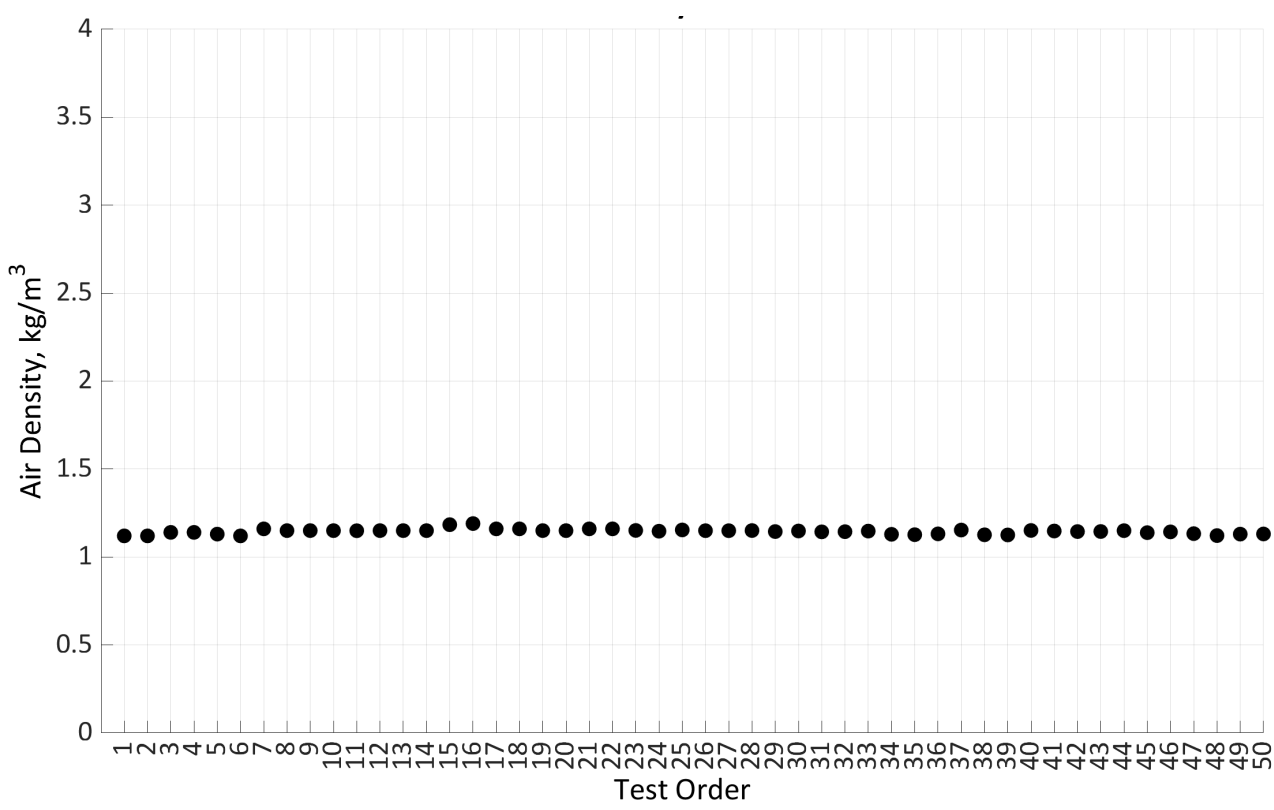

G.21 Engine Inlet Air Density vs. Test Order 


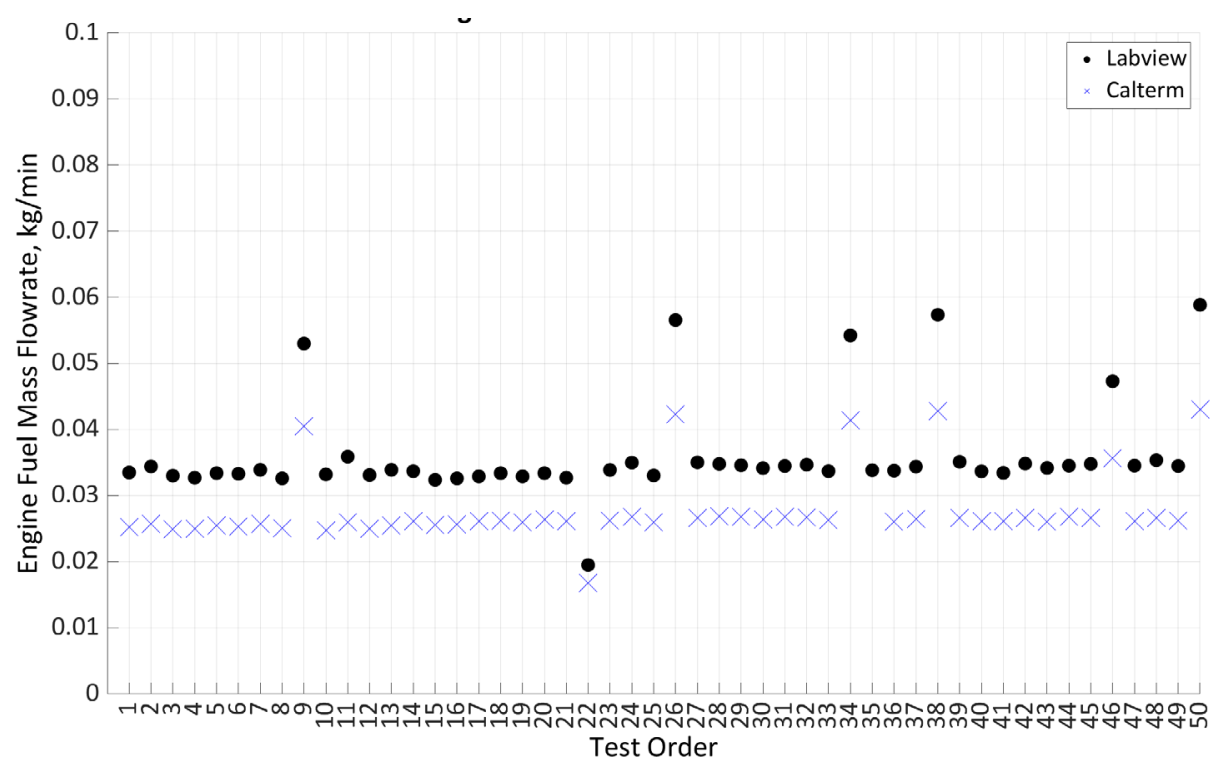

G.22 Coriolis Fuel Flow Meter (LabVIEW) and Calculated (Calterm) Fuel Flow Rate vs.

Test Order

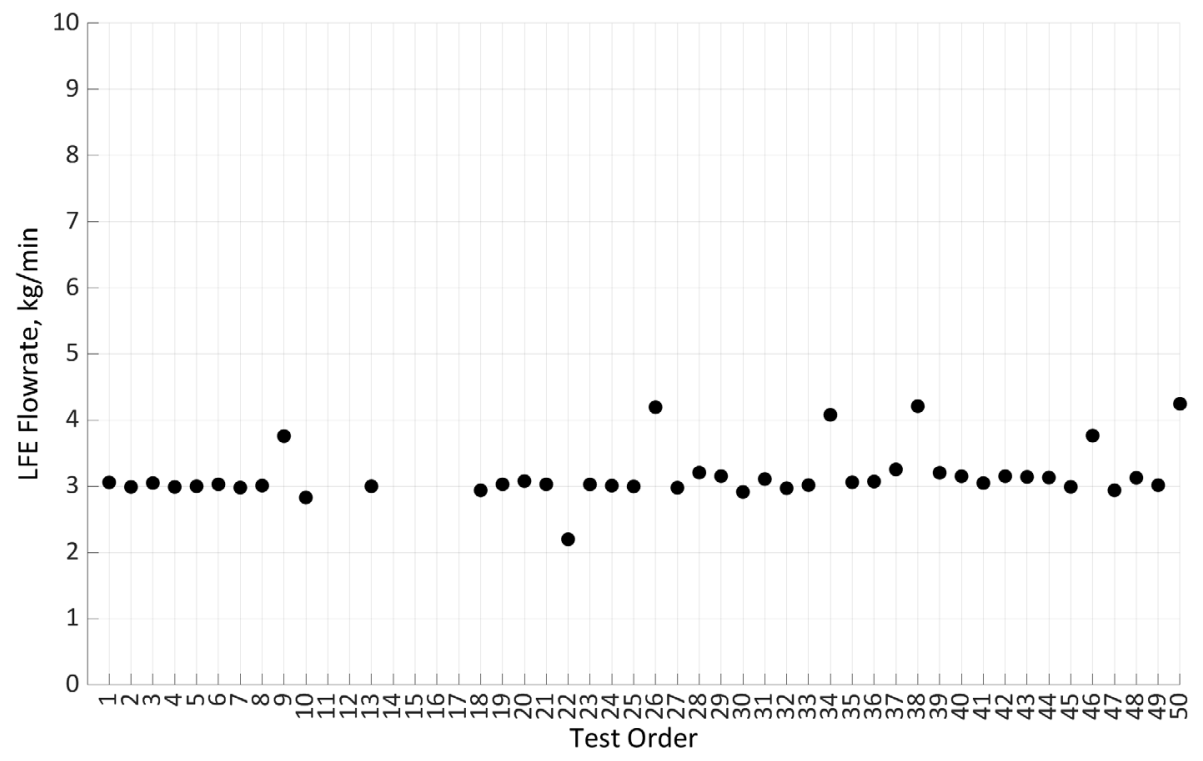

G.23 Laminar Flow Element Engine Intake Air Mass Flow Rate vs. Test Order 


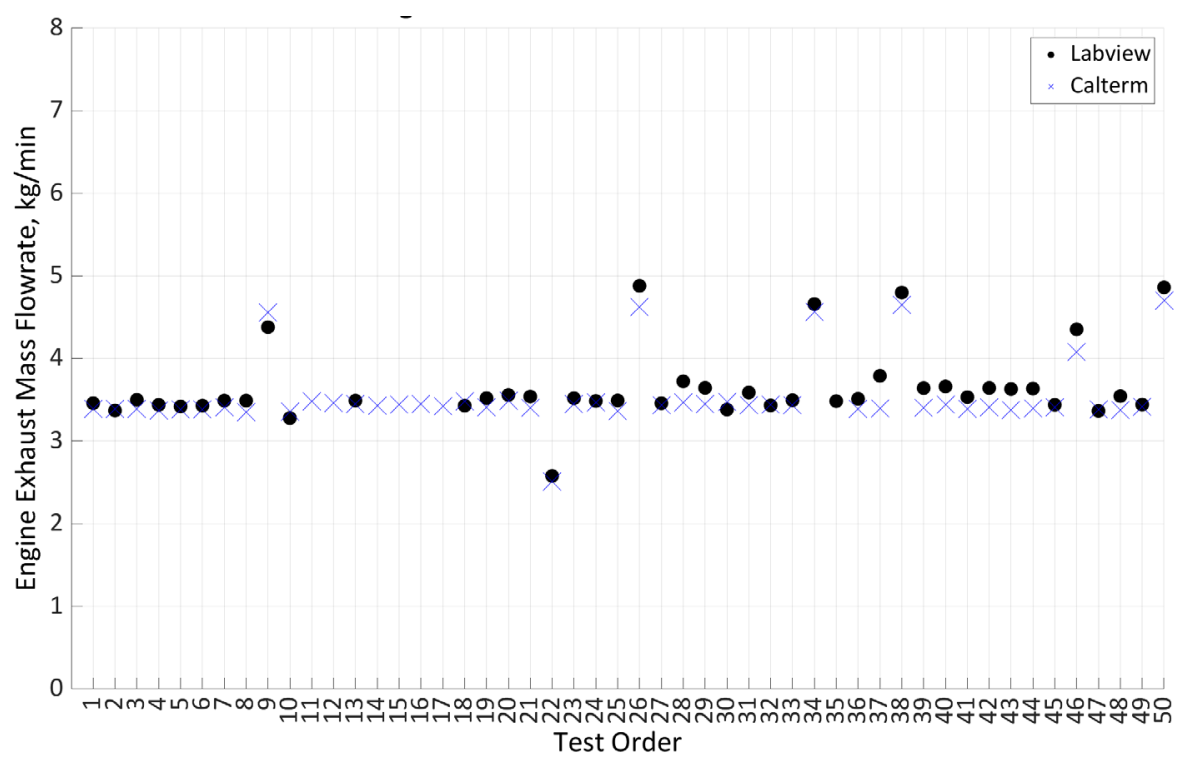

G.24 Engine Exhaust Mass Flow Rate Measured (LabVIEW) and Calculated (Calterm) vs. Test Order

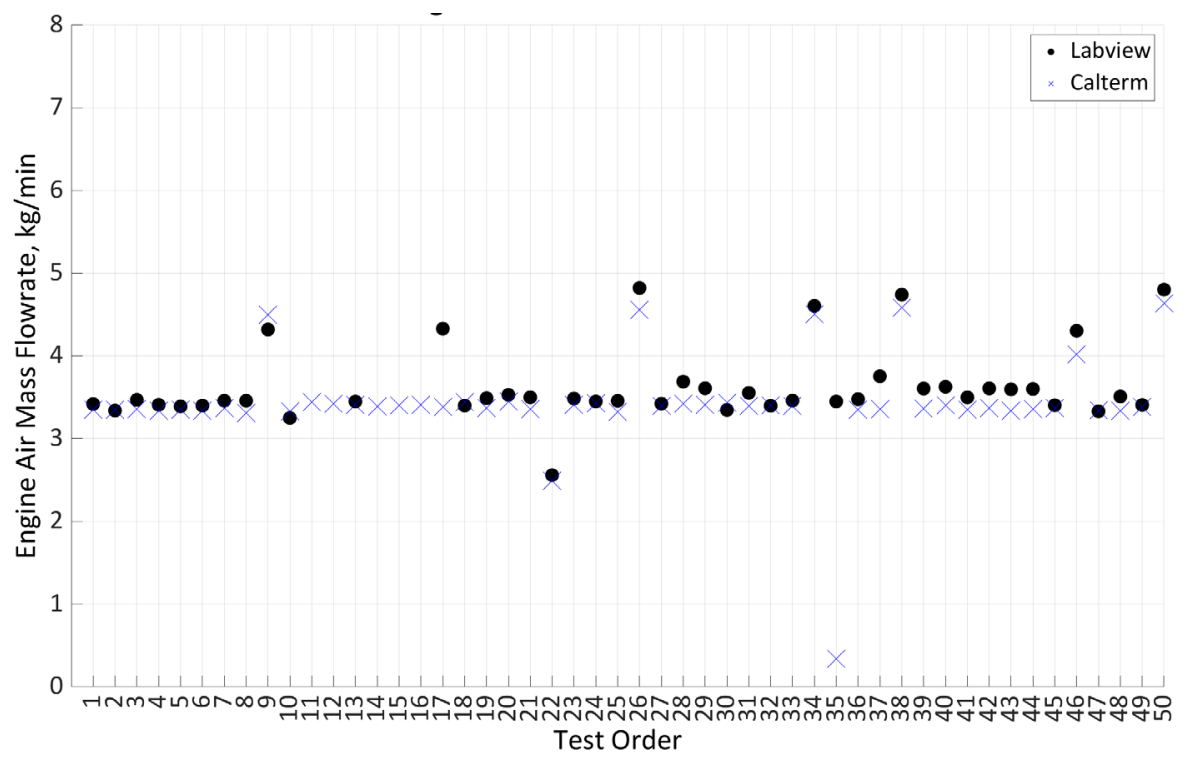

G.25 Engine Air Mass Flow Rate Measured (LabVIEW) and Calculated (Calterm) vs.

Test Order 


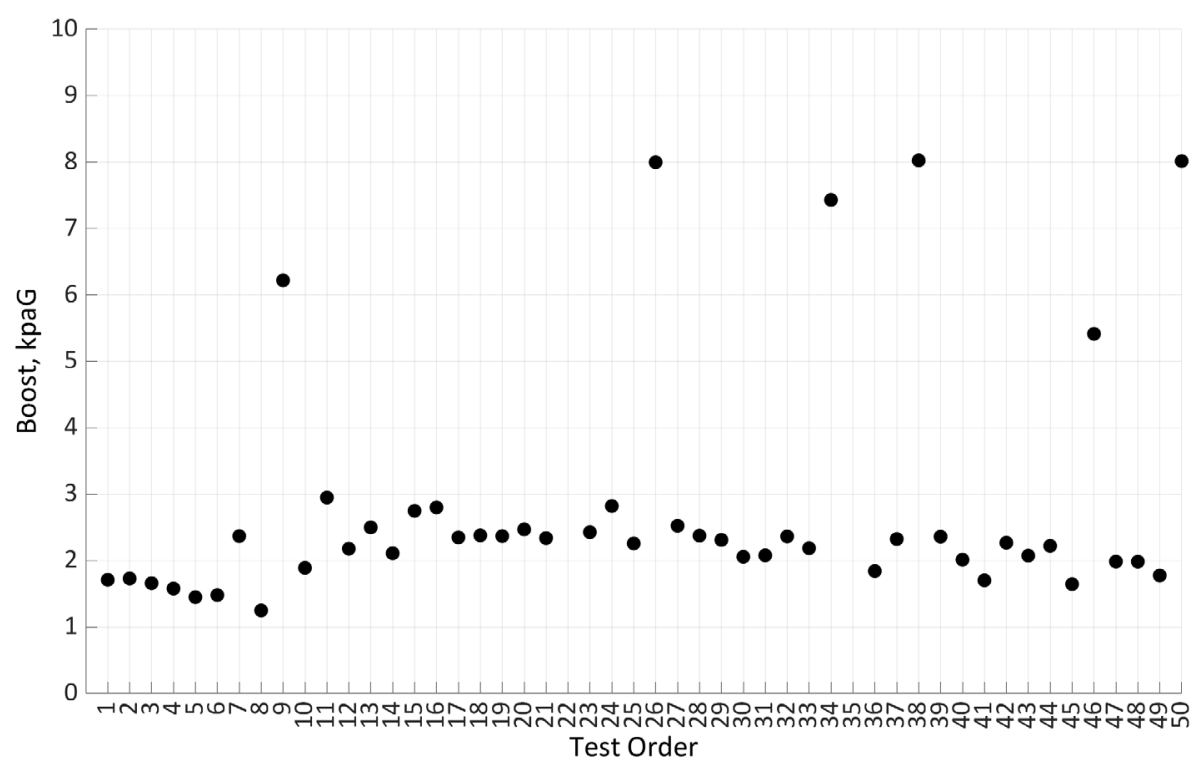

G.26 Engine Intake Boost (Calterm) vs. Test Order

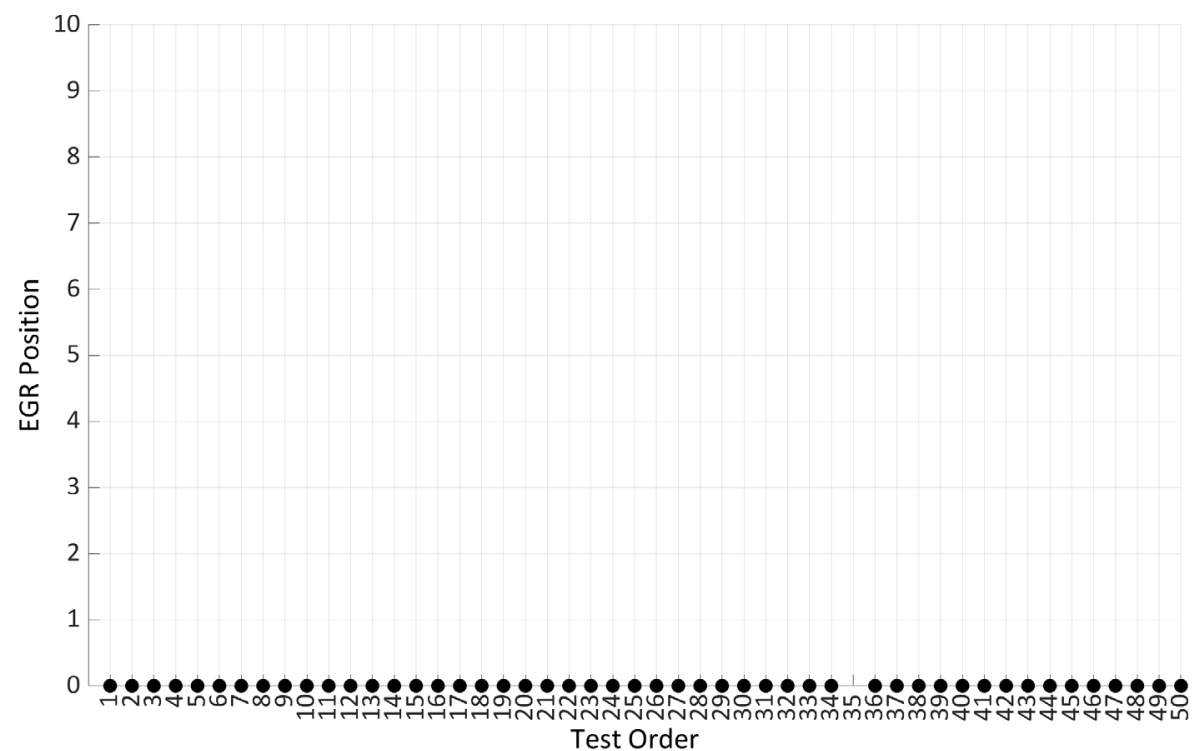

G.27 Engine EGR Position (Calterm) vs. Test Order 


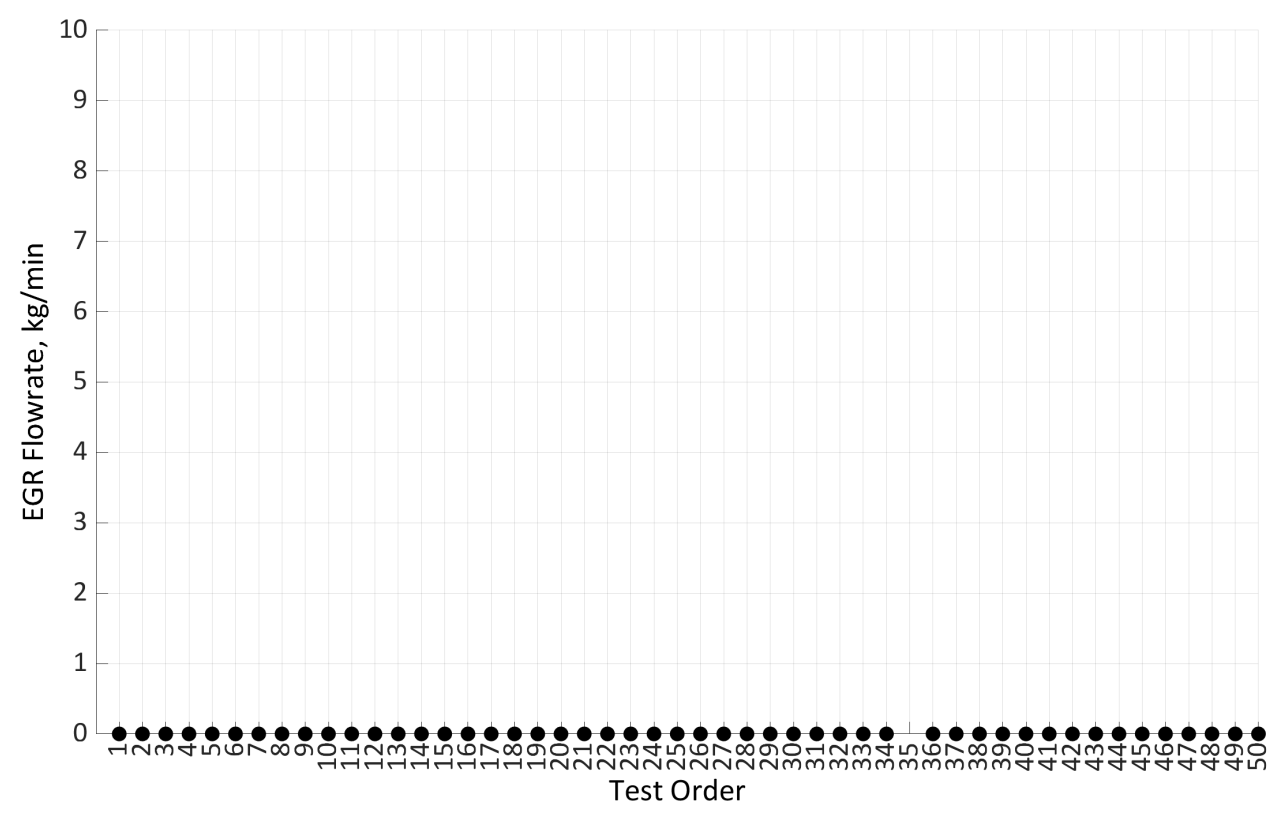

G.28 Engine EGR Flow Rate (Calterm) vs. Test Order

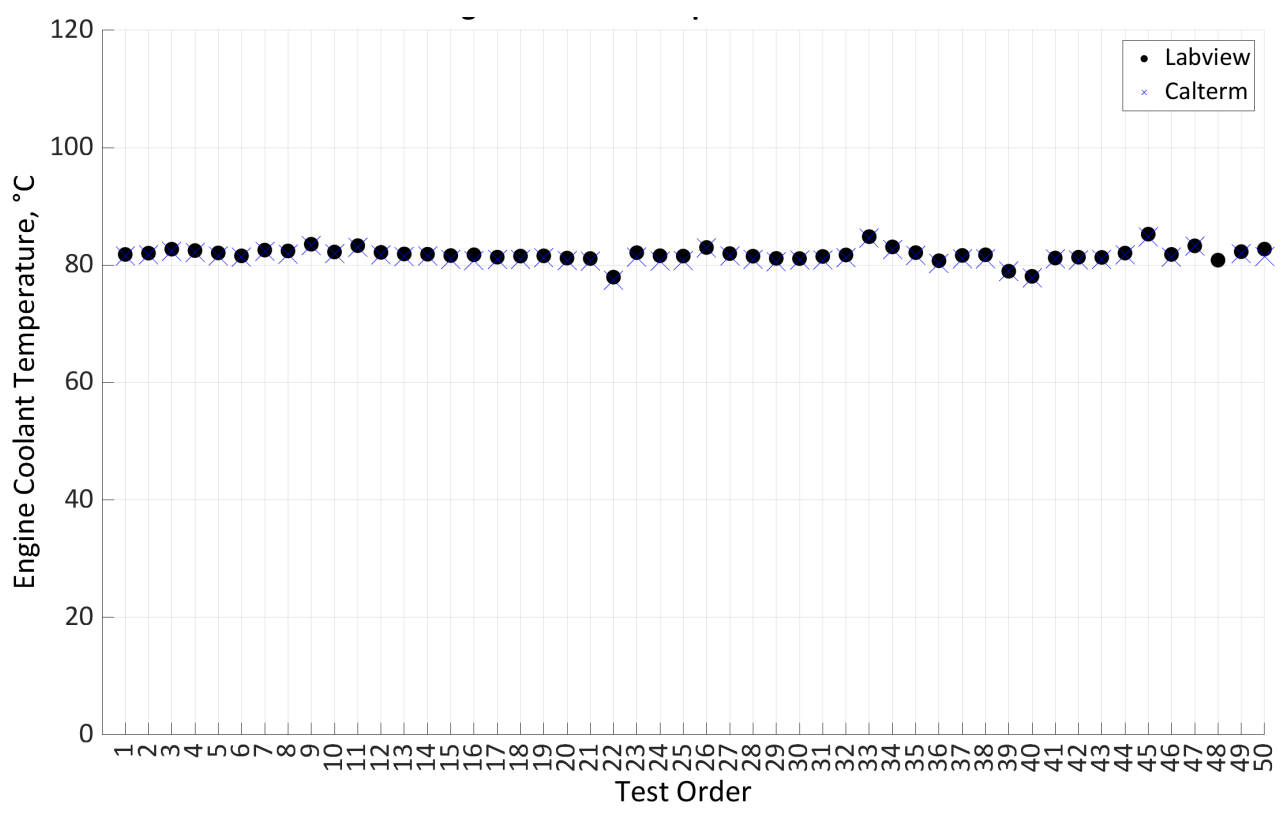

G.29 Engine Coolant Temperature (LabVIEW and Calterm) vs. Test Order 


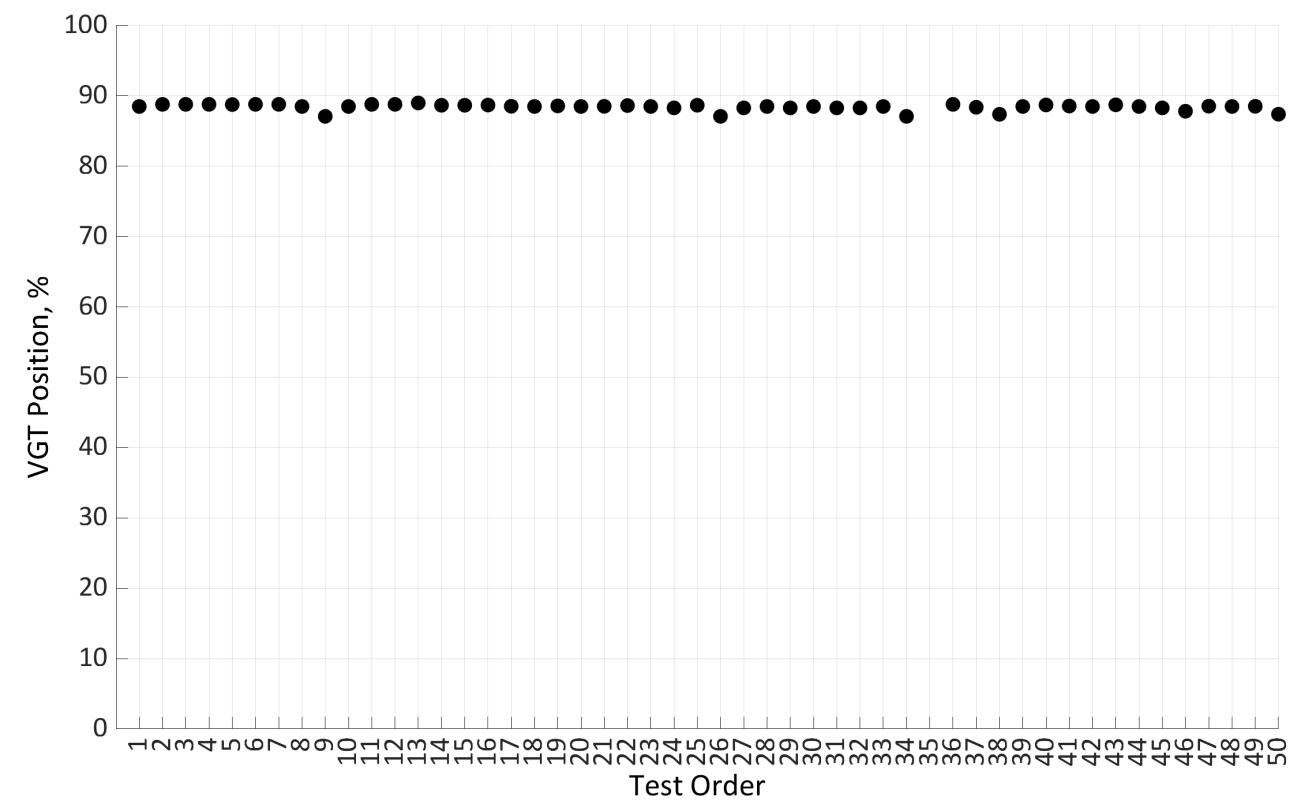

G.30 Engine Variable Geometry Turbo Position (Calterm) vs. Test Order

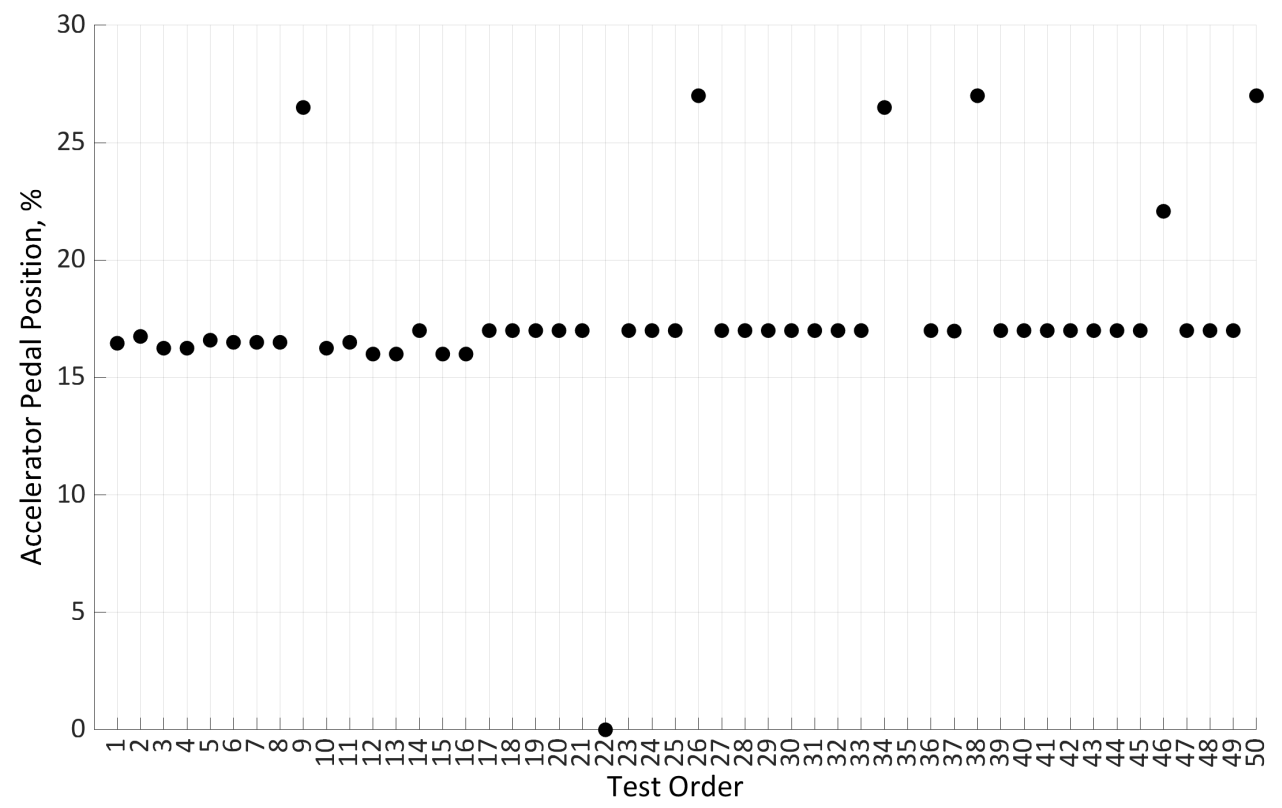

G.31 Engine Accelerator Pedal Position (Calterm) vs. Test Order 


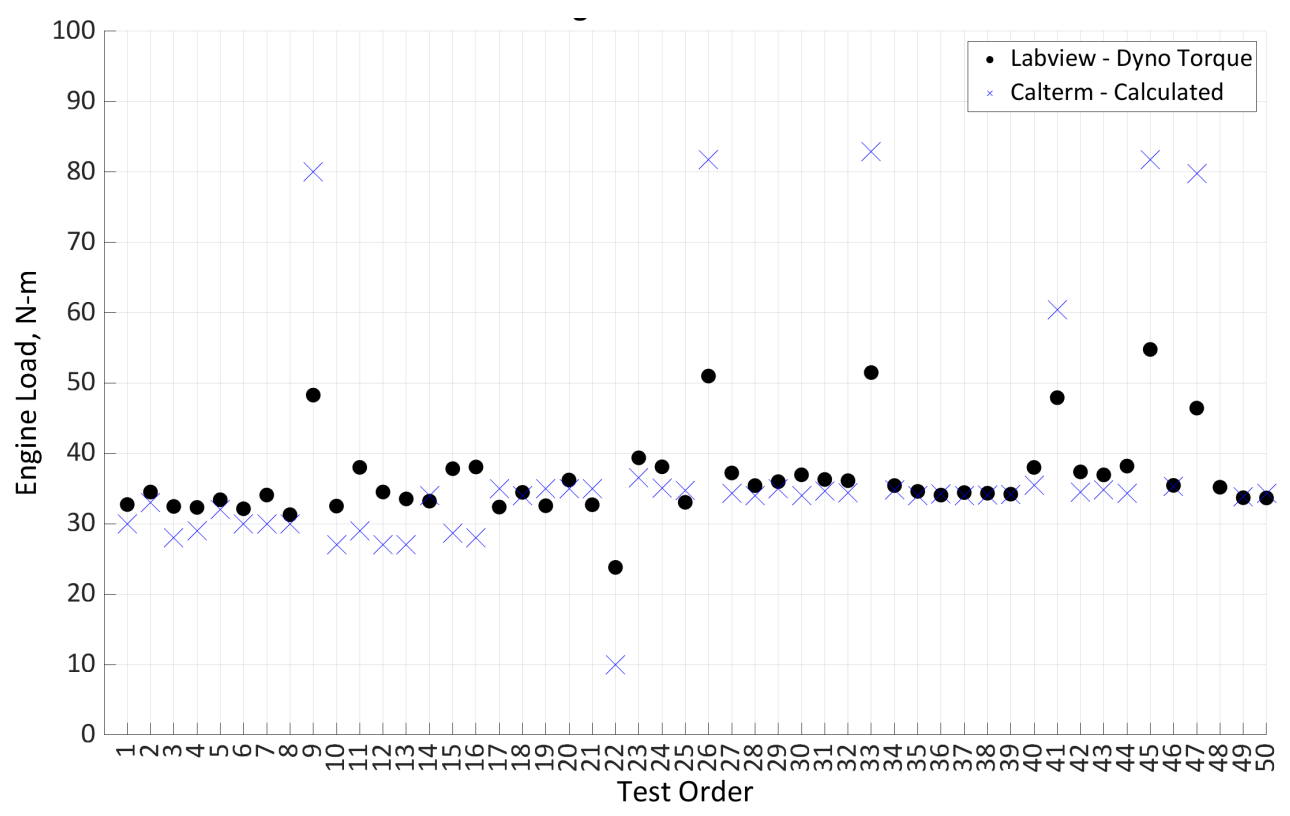

G.32 Engine Load vs. Test Order

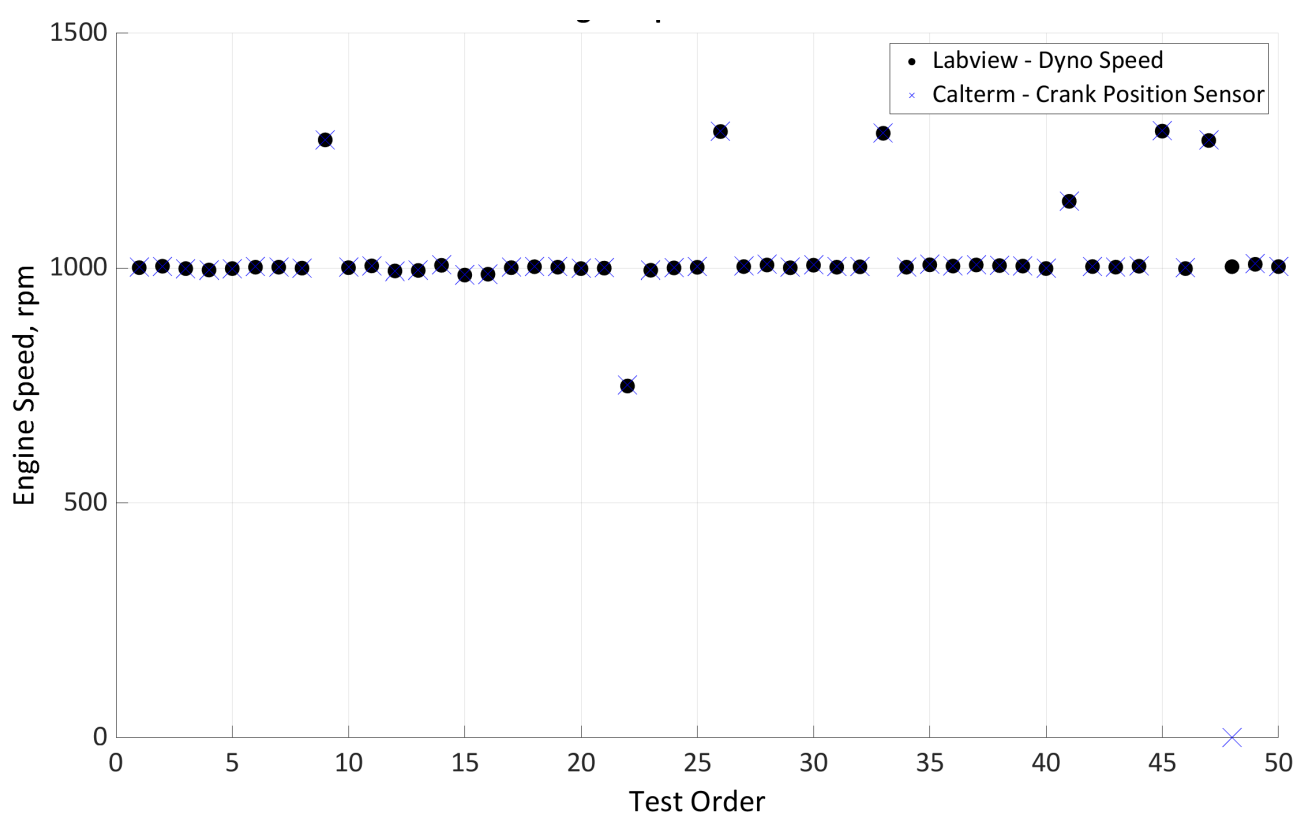

G.33 Engine Speed vs. Test Order 


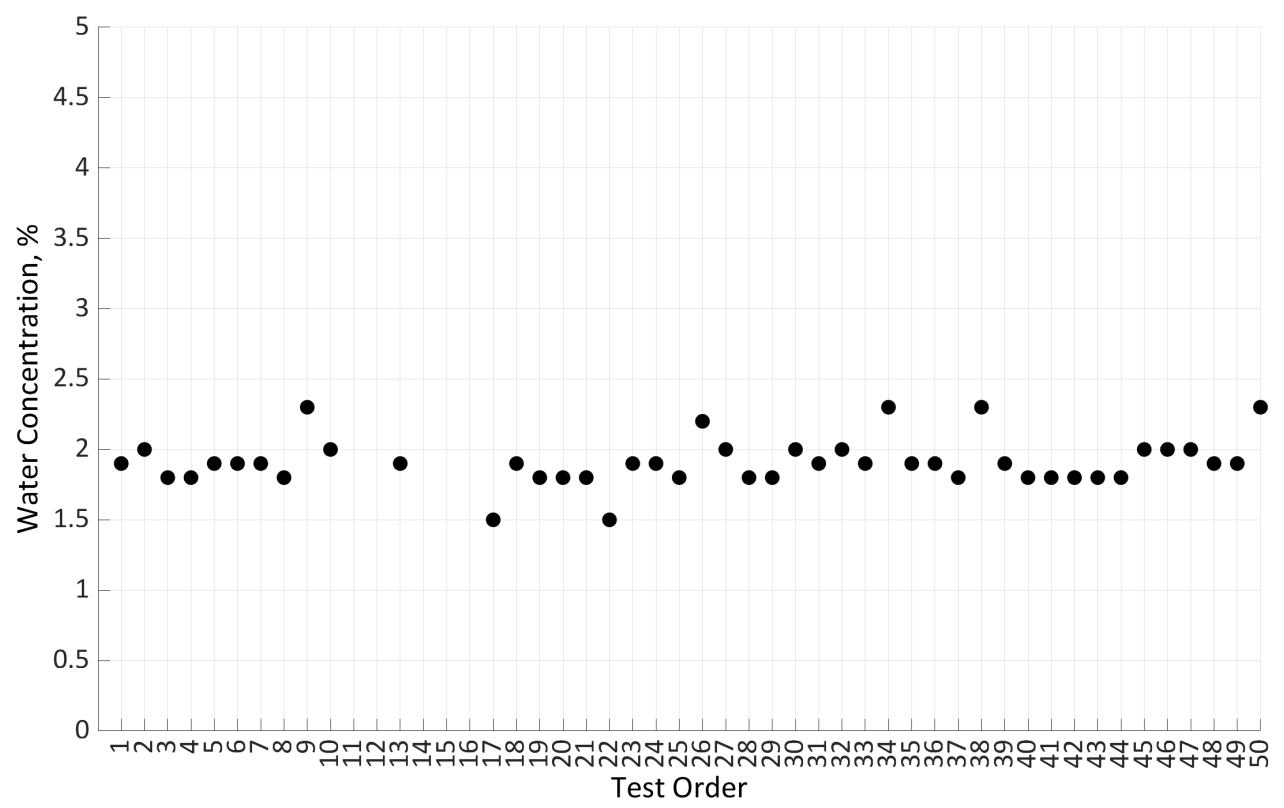

G.34 Engine Out $\mathrm{H}_{2} \mathrm{O}$ Concentration Calculated from LabVIEW Flowrate AFR vs. Test Order

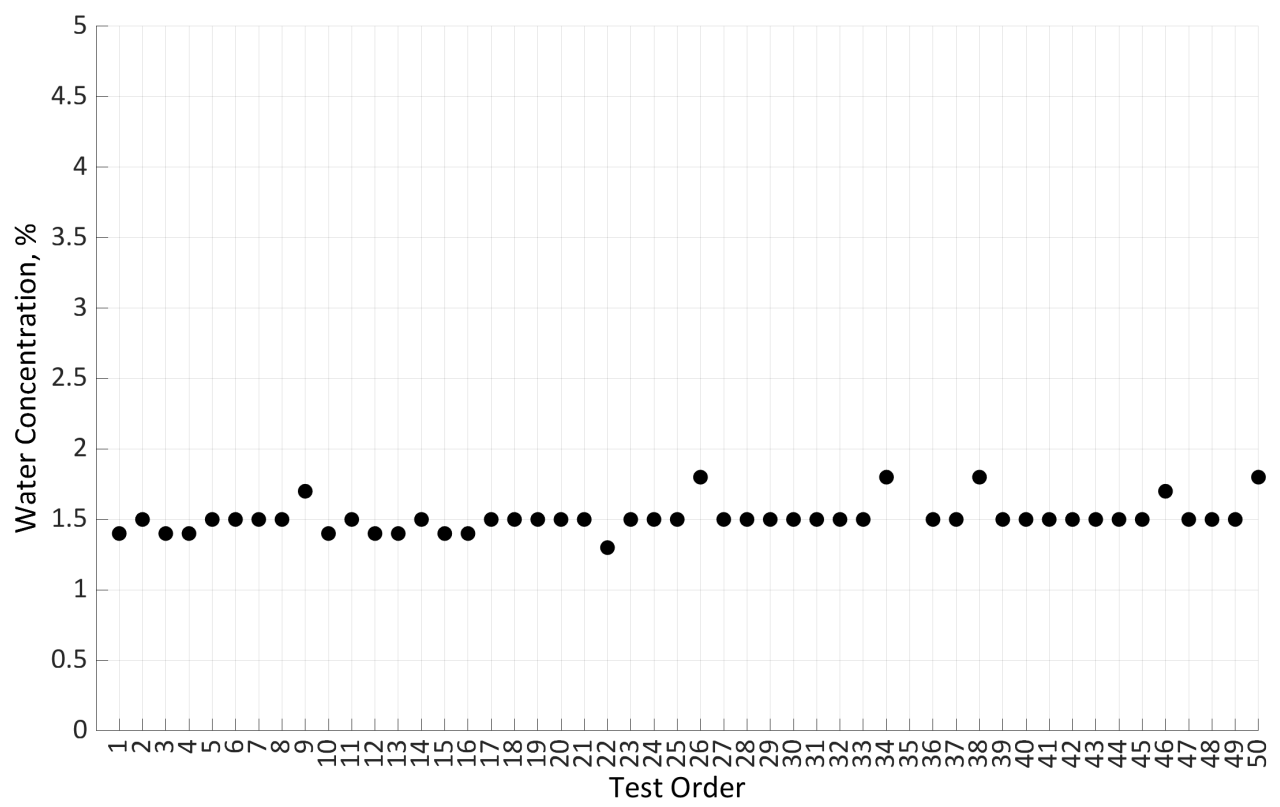

G.35 Engine Out $\mathrm{H}_{2} \mathrm{O}$ Concentration Calculated from Calterm Flowrate AFR vs. Test Order 


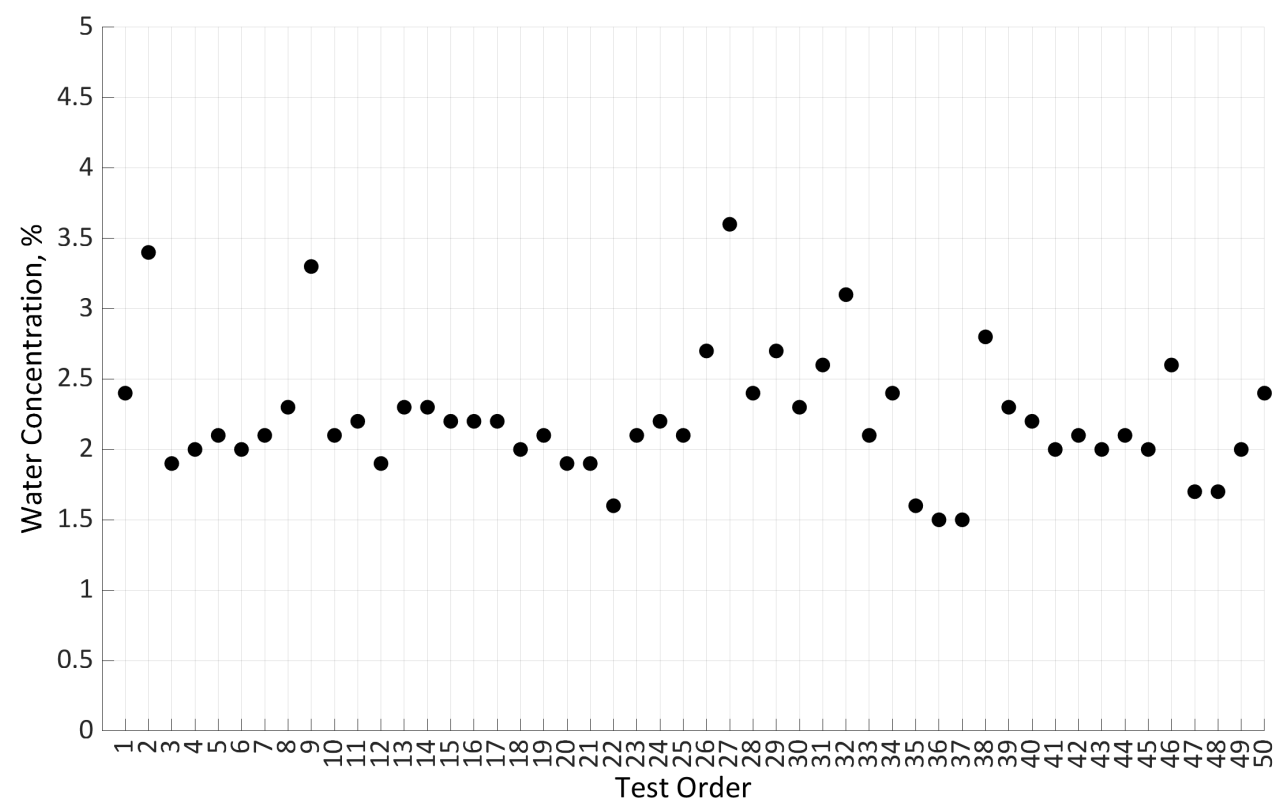

G.36 Engine Out $\mathrm{H}_{2} \mathrm{O}$ Concentration Calculated from Pierburg Engine Out $\mathrm{CO}_{2}$

Concentration vs. Test Order

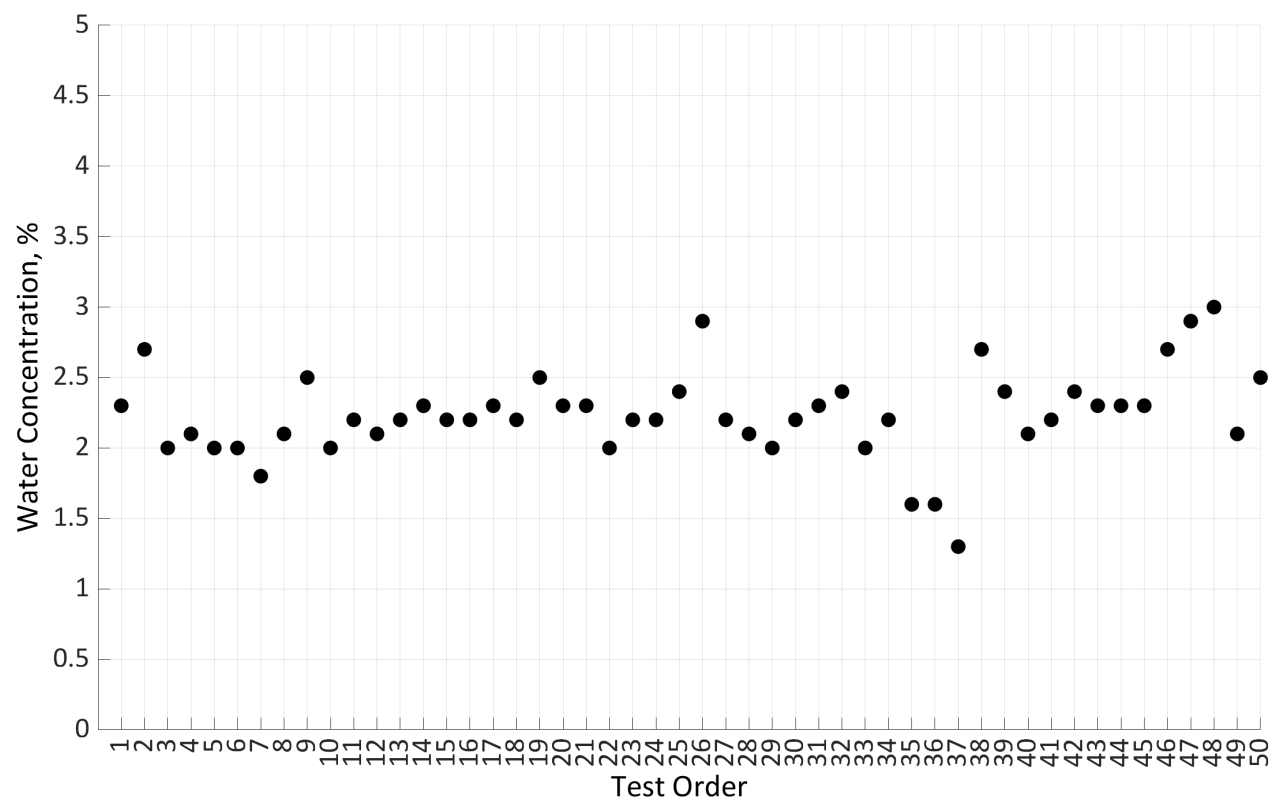

G.37 Engine Out $\mathrm{H}_{2} \mathrm{O}$ Concentration Calculated from Pierburg Engine Out $\mathrm{O}_{2}$ Concentration vs. Test Order 


\section{Appendix $\mathrm{H} . \quad \mathrm{N}_{2} \mathrm{O}$ Formulation Reactions}

The following equations are used to describe the $\mathrm{N}_{2} \mathrm{O}$ formulation reactions within the dCSC $^{\text {тM }}$ per reference $[19,28]$. Equation H.1 describes the NO reduction reaction that results in $\mathrm{N}_{2} \mathrm{O}$ production.

$$
2 \mathrm{NO} \rightarrow 0.5 \mathrm{O}_{2}+\mathrm{N}_{2} \mathrm{O}
$$

Where $\mathrm{NO}$ forms $\mathrm{N}_{2} \mathrm{O}$ and $\mathrm{O}_{2}$. Equation $\mathrm{H} .2$ describes the reaction between $\mathrm{C}_{3} \mathrm{H}_{6}$ and $\mathrm{NO}_{2}$ causing a formulation of $\mathrm{CO}, \mathrm{H}_{2} \mathrm{O}$, and $\mathrm{N}_{2} \mathrm{O}$.

$$
\mathrm{C}_{3} \mathrm{H}_{6}+4 \mathrm{NO}_{2} \leftrightarrow 3 \mathrm{CO}+3 \mathrm{H}_{2} \mathrm{O}+2 \mathrm{~N}_{2} \mathrm{O}
$$




\section{Appendix I. $\quad \mathrm{CO}, \mathrm{HC}$, and NO Oxidation Reactions}

The following equations describe the oxidation reactions within the $\mathrm{dCSC} \mathrm{CM}^{\mathrm{TM}}$. The equations were found in reference [27]. Equation H.1 defines the HC oxidation reaction.

$$
\mathrm{HC}+\mathrm{O}_{2} \rightarrow \mathrm{CO}_{2}+\mathrm{H}_{2} \mathrm{O}
$$

Where $1 \mathrm{HC}$ atom is oxidized with $1 \mathrm{O}_{2}$ atom to form carbon dioxide, $\mathrm{CO}_{2}$, and water vapor, $\mathrm{H}_{2} \mathrm{O}$. Equation $\mathrm{H} .2$ describes the oxidation reaction of $\mathrm{CO}$.

$$
\mathrm{CO}+\mathrm{O}_{2} \rightarrow 2 \mathrm{CO}_{2}
$$

Where $2 \mathrm{CO}$ atoms are oxidized with $1 \mathrm{O}_{2}$ to form $2 \mathrm{CO}_{2}$ atoms. Equation H.3 describes the oxidation reaction of NO.

$$
\mathrm{NO}+\frac{1}{2} \mathrm{O}_{2} \leftrightarrow \mathrm{NO}_{2}
$$

Where $1 \mathrm{NO}$ atom is oxidized with $1 / 2$ of an $\mathrm{O}_{2}$ atom to form $1 \mathrm{NO}_{2}$ atom. 


\section{Appendix J. $\quad$ Additional Substrate Thermocouples}

Additional substrate temperature instrumentation is needed in order to capture temperature gradient. Figure H.1 shows the dCSC $^{\text {тM }}$ radial temperature gradient measured during a steady state temperature condition of $250^{\circ} \mathrm{C}$. It is recommended for future testing to add rows of thermocouples at the locations indicated in Figure I.1.

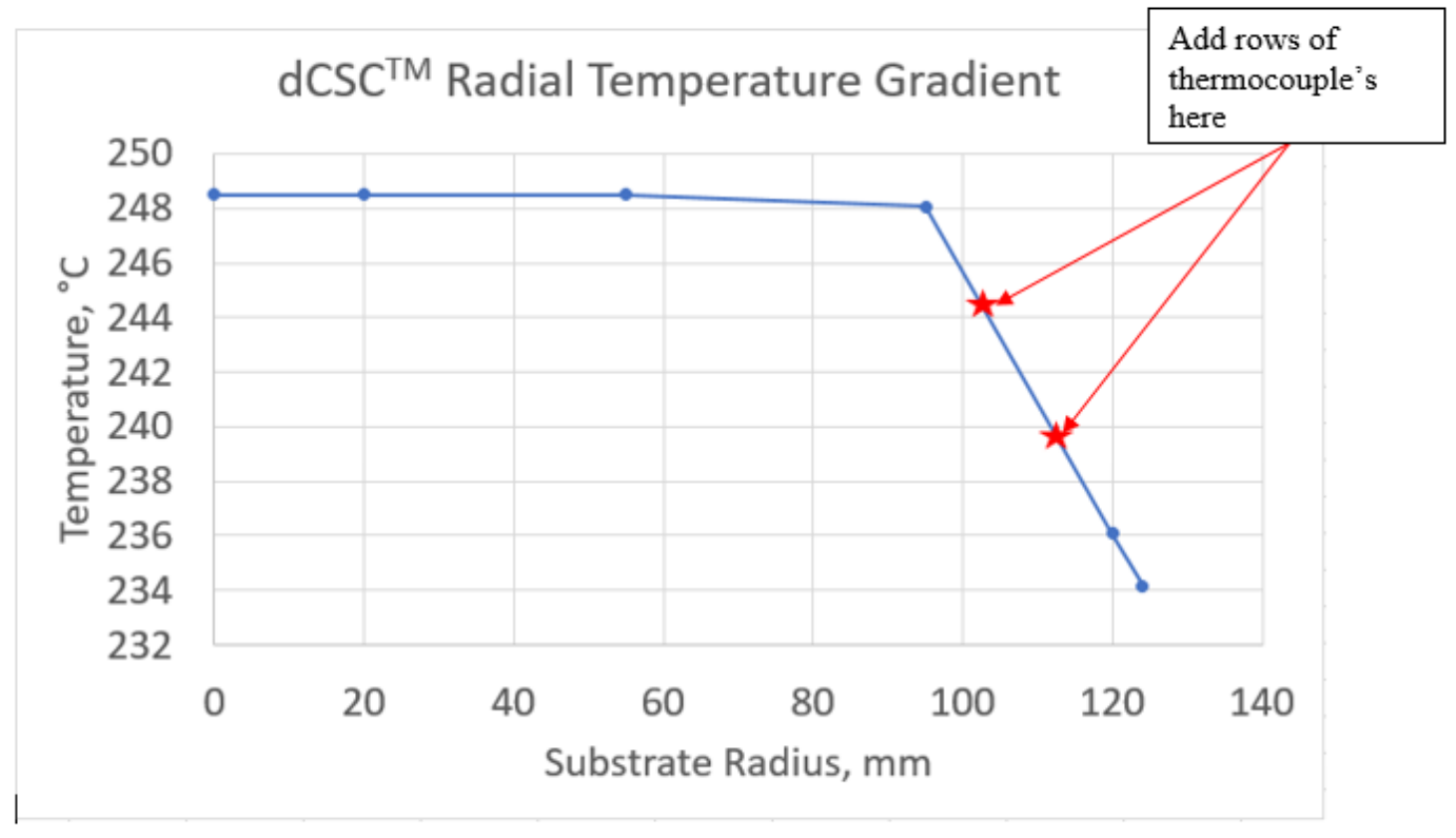

J.1 Recommended Additional Thermocouples to Measure Temperature 


\section{Appendix K. $\quad$ Copyright Documentation}

\section{K.1. \\ Figure 1.1 Possible ULN ATS Compared to Current ATS}

Conor Berndt <ctberndt@mtu.edu>

Tue, Oct 29, 2019 at 4:33 PM

To: alissa.recker@daimler.com

Dear Alissa,

I am writing to request permission to reference a figure from your presentation "Fuel contaminants, effects on aftertreatment, and their limits on NOx stringency and extended useful life" - from the UW Symposium. The figure is shown below.

The figure would appear in my thesis titled: "AN EXPERIMENTAL STUDY OF A PASSIVE NOX ADSORBER (PNA) FOR THE REDUCTION OF COLD START DIESEL EMISSIONS."

Is there a paper this figure appears in? Otherwise I would reference the presentation in the figure caption and text.

Thank you for your time,

\section{Conor Berndt}

Mechanical Engineering - Graduate Student

Michigan Technological University 
Email: ctberndt@mtu.edu

Phone: (906) 221-6485

MEEM B008

Conor Berndt <ctberndt@mtu.edu>

Wed, Nov 6, 2019 at 1:12 PM

To: alissa.recker@daimler.com

Hi Alissa,

I was wondering if you received my first email? Please let me know if you have any questions.

Thanks,

\section{Conor Berndt}

Mechanical Engineering - Graduate Student

Michigan Technological University

Email: ctberndt@mtu.edu

Phone: (906) 221-6485

MEEM B008 
To: ctberndt@mtu.edu

Hi Conor,

Sorry for the delayed response. Yes, you can use it. It's really just a simple schematic of some of the proposals we've been seeing from CARB and Southweast Research. You can find more of them in the CARB White Paper:

https://ww3.arb.ca.gov/msprog/hdlownox/white paper 04182019a.pdf

Thanks,

Alissa Recker

Catalyst Kit Engineer 
ATS Performance TP/PNF

Daimler Trucks Powertrain Engineering NAFTA

Cell: +1313 452-3926

Desk: +1 313 592-5689

[Quoted text hidden]

If you are not the addressee, please inform us immediately that you have received this e-mail by mistake, and delete it. We thank you for your support.

\section{K.2. Copyright Permission for Thesis Figure 1.2 Turbine Outlet}

\section{Temperature vs. AFR}

Conor Berndt <ctberndt@mtu.edu> Tue, Oct 29, 2019 at 3:31 PM

To: gshaver@purdue.edu

Dear Dr. Shaver,

I am writing to request permission to use Figure 2.2 from Mark Magee's masters thesis

"Exhaust Thermal Management

Using Cylinder Deactivation and Late Intake Valve Closing" as a reference for my own masters thesis at Michigan

Technological University.

My thesis will be titled "AN EXPERIMENTAL STUDY OF A PASSIVE NOX ADSORBER (PNA) FOR THE REDUCTION

OF COLD START DIESEL EMISSIONS". 
Any assistance in obtaining permission to use the figure would be greatly appreciated.

Thank you for your time and consideration,

Conor Berndt

Mechanical Engineering - Graduate Student

Michigan Technological University

Email: ctberndt@mtu.edu

Phone: (906) 221-6485

MEEM B008

Shaver, Gregory M < gshaver@purdue.edu> Tue, Oct 29, 2019 at 3:33 PM

To: Conor Berndt $<$ ctberndt@mtu.edu $>$

Dear Conor,

I approve. I assume you would add a citation to Mark's thesis in the caption?

Greg

[Quoted text hidden]

Conor Berndt <ctberndt@mtu.edu> Tue, Oct 29, 2019 at 3:34 PM

To: "Shaver, Gregory M" <gshaver@purdue.edu>

Greg,

Thank you very much. Yes, I would cite Mark's thesis in the figure caption and where mentioned in the text. 
Kind regards,

Conor Berndt

Mechanical Engineering - Graduate Student

Michigan Technological University

Email: ctberndt@mtu.edu

Phone: (906) 221-6485

MEEM B008

11/6/2019 Michigan Technological University Mail - Copyright Permission - Mark E.

Magee Master's Thesis

https://mail.google.com $/ \mathrm{mail} / \mathrm{u} / 0$ ?ik=8713e930df\&view=pt\&search=all\&permthid=threa

d-a\%3Ar2947794484981180417\&simpl=msg-a\%3Ar753846069 .. 2/2

[Quoted text hidden]

Shaver, Gregory M < gshaver@purdue.edu> Tue, Oct 29, 2019 at 3:36 PM

To: Conor Berndt <ctberndt@mtu.edu>

Sounds good, Conor. Best wishes finishing up.

Cheers,

[Quoted text hidden]

Conor Berndt <ctberndt@mtu.edu $>$ Tue, Oct 29, 2019 at 3:36 PM

To: "Shaver, Gregory M" < gshaver@purdue.edu>

Thank you! 
Conor Berndt

Mechanical Engineering - Graduate Student

Michigan Technological University

Email: ctberndt@mtu.edu

Phone: (906) 221-6485

MEEM B008

[Quoted text hidden]

K.3. Copyright Permission for Thesis Figure 2.2 NOx Adsorption/Storage, Figure 2.3 NOx Desorption/Release, and Figure 2.4 Effects of $\mathrm{H}_{2} \mathrm{O}$ on NOx adsorption

Conor Berndt $<$ ctberndt@mtu.edu> Fri, Oct 25, 2019 at 9:48 AM

To: mharold@uh.edu, samalamis@uh.edu

$\mathrm{Hi}$,

I am writing to request permission to reference figures from the attached presentation from the 2018 CLEERS

conference. They would appear in the Literature Review Chapter of my master's thesis titled "AN EXPERIMENTAL

STUDY OF A PASSIVE NOX ADSORBER (PNA) FOR THE REDUCTION OF COLD START DIESEL EMISSIONS".

The figures I would like to reference are the NOx adsorption, NOx desorption, and water inhibition of NOx storage 
figures.

Please let me know if you have any questions,

Thank you for your time,

Conor Berndt

Mechanical Engineering - Graduate Student

Michigan Technological University

Email: ctberndt@mtu.edu

Phone: (906) 221-6485

MEEM B008

\section{CLEERS_SamMalamis_Web.pptx}

$3109 K$

Harold, Michael P <MPHarold@central.uh.edu $>$ Fri, Oct 25, 2019 at 11:25 AM

To: Conor Berndt < ctberndt@mtu.edu>

Cc: "Malamis, Sotirios A" < samalamis@uh.edu>

Dear Conor,

That will be fine. Or you could reference the paper that is related to that presentation which will be accepted soon. It

is

S. Malamis, M.P. Harold, W.S. Epling, "Coupled NO and C3H6 Trapping, Release and Conversion on Pd-BEA: 
Evaluation of The Lean Hydrocarbon $\mathrm{NO} \neg x$ Trap,” in press, Ind. Eng. Chem. Res. (2019).

The paper should appear by mid November on the IECR website.

Best wishes,

11/6/2019 Michigan Technological University Mail - 2018 CLEERS Presentation

Reference

https://mail.google.com $/ \mathrm{mail} / \mathrm{u} / 0$ ?ik=8713e930df\&view=pt\&search=all\&permthid=threa d-a\%3Ar-7940216985565214836\&simpl=msg-a\%3Ar22165828 .. 2/2

Mike Harold

[Quoted text hidden]

Conor Berndt $<$ ctberndt@mtu.edu $>$ Mon, Oct 28, 2019 at 2:06 PM

To: "Harold, Michael P" < MPHarold@central.uh.edu>

Cc: "Malamis, Sotirios A" <samalamis@uh.edu>

Dear Mike,

Thank you very much! I will use the paper citation you have provided to cite the figures.

I appreciate the timely response.

Conor Berndt

Mechanical Engineering - Graduate Student

Michigan Technological University

Email: ctberndt@mtu.edu 
Phone: (906) 221-6485

MEEM B008

[Quoted text hidden]

\section{K.4. Copyright Permission for Thesis Figure 2.1 ULN ATS used on a Volvo MY 13.0L Diesel Engine at SwRI}

\begin{tabular}{|c|c|c|c|}
\hline \multicolumn{4}{|c|}{$\begin{array}{l}\text { Copyright } \\
\text { Clearance } \\
\text { Center }\end{array}$} \\
\hline \multicolumn{4}{|c|}{$\begin{array}{l}\text { This is a License Agreement between Conor Berndt, MS Candidate, Michigan Technological University ("You") and SAE International ("Publisher") provided by Copyright Clearance } \\
\text { Center ("СCC"). The license consists of your order details, the terms and conditions provided by SAE International, and the CCC terms and conditions. } \\
\text { All payments must be made in full to CCC. }\end{array}$} \\
\hline $\begin{array}{l}\text { Order Date } \\
\text { Order license ID } \\
\text { System ID }\end{array}$ & $\begin{array}{l}22-\text { Oct-2019 } \\
1000169-1 \\
2017-01-0958\end{array}$ & $\begin{array}{l}\text { Type of Use } \\
\text { Publisher } \\
\text { Portion }\end{array}$ & $\begin{array}{l}\text { Republish in a thesis/dissertation } \\
\text { SAE International } \\
\text { Image/photo/illustration }\end{array}$ \\
\hline \multicolumn{4}{|l|}{ LICENSED CONTENT } \\
\hline Publication Title & $\begin{array}{l}\text { Achieving Ultra Low NOX Emissions Levels } \\
\text { with a } 2017 \text { Heavy-Duty On-Highway TC } \\
\text { Diesel Engine and an Advanced Technology } \\
\text { Emissions System - NOX Management } \\
\text { Strategies }\end{array}$ & $\begin{array}{l}\text { Country } \\
\text { Rightsholder } \\
\text { Publication Type }\end{array}$ & $\begin{array}{l}\text { United States of America } \\
\text { SAE International } \\
\text { Report }\end{array}$ \\
\hline $\begin{array}{l}\text { Author/Editor } \\
\text { Date }\end{array}$ & $\begin{array}{l}\text { Sharp, Christopher } \\
01 / 01 / 2017\end{array}$ & & \\
\hline \multicolumn{4}{|l|}{ REQUEST DETAILS } \\
\hline Portion Type & Image/photo/illustration & Distribution & Worldwide \\
\hline Number of images / photos / illustrations & 1 & Translation & Original language of publication \\
\hline Format (select all that apply) & Electronic & Copies for the disabled? & No \\
\hline Who will republish the content? & Academic institution & Minor editing privileges? & No \\
\hline Duration of Use & Life of current edition & Incidental promotional use? & No \\
\hline Lifetime Unit Quantity & More than $2,000,000$ & Currency & USD \\
\hline $\begin{array}{l}\text { Rights Requested } \\
\text { NEW WORK DETAILS }\end{array}$ & Main product & & \\
\hline Title & $\begin{array}{l}\text { AN EXPERIMENTAL STUDY OF A PASSIVE } \\
\text { NOX ADSORBER (PNA) FOR THE } \\
\text { REDUCTION OF COLD START DIESEL } \\
\text { EMISSIONS }\end{array}$ & $\begin{array}{l}\text { Institution name } \\
\text { Expected presentation date }\end{array}$ & $\begin{array}{l}\text { Michigan Technological University } \\
\text { 2019-11-19 }\end{array}$ \\
\hline $\begin{array}{l}\text { Instructor name } \\
\text { ADDITIONAL DETAILS }\end{array}$ & Dr. Jeffrey D. Naber & & \\
\hline Order reference number & N/A & $\begin{array}{l}\text { The requesting person / organization to } \\
\text { appear on the license }\end{array}$ & $\begin{array}{l}\text { Conor Berndt, MS Candidate, Michigan } \\
\text { Technological University }\end{array}$ \\
\hline
\end{tabular}


Title, description or numeric reference of the portion(s)

Editor of portion(s)

Volume of serial or monograph

Page or page range of portion
Figure 4 Final Low NOx Aftertreatment System

SAE International Journal of Engines

1738
Title of the article/chapter the portion is

from

Author of portion(s)

Issue, if republishing an article from a

serial

Publication date of portion
N/A

Sharp, Christopher

2017-01-01

\section{Republication Terms and Conditions}

1. Description of Service; Defined Terms. This Republication License enables the User to obtain licenses for republication of one or more copyrighted works as described in detail on the relevant Order Confirmation (the "Work(s)"). Copyright Clearance Center, Inc. ("CCC") grants licenses through the Service on behalf of the rightsholder identified on the Order Confirmation (the "Rightsholder"). "Republication", as used herein, generally means the inclusion of a Work, in whole or in part, in a new work or works, also as described on the Order Confirmation. "User", as used herein, means the person or entity making such republication.

2. The terms set forth in the relevant Order Confirmation, and any terms set by the Rightsholder with respect to a particular Work, govern the terms of use of Works in connection with the Service. By using the Service, the person transacting for a republication license on behalf of the User represents and warrants that he/she/it (a) has been duly authorized by the User to accept, and hereby does accept, all such terms and conditions on behalf of User, and (b) shall inform User of all such terms and conditions. In the event such person is a deemed to have accepted and agreed to all such terms and conditions if User republishes the Work in any fashion.

3. Scope of License; Limitations and Obligations.

3.1. All Works and all rights therein, including copyright rights, remain the sole and exclusive property of the Rightsholder. The license created by the exchange of an Orde Confirmation (and/or any invoice) and payment by User of the full amount set forth on that document includes only those rights expressly set forth in the Order Confirmation and in these terms and conditions, and conveys no other rights in the Work(s) to User. All rights not expressly granted are hereby reserved.

3.2. General Payment Terms: You may pay by credit card or through an account with us payable at the end of the month. If you and we agree that you may establish a standing account with CCC, then the following terms apply: Remit Payment to: Copyright Clearance Center, 29118 Network Place, Chicago, IL 60673-1291. Payments Due: Invoices are payable upon their delivery to you (or upon our notice to you that they are available to you for downloading). After 30 days, outstanding amounts will be subject to a service
charge of $1-1 / 2 \%$ per month or, if less, the maximum rate allowed by applicable law. Unless otherwise specifically set forth in the Order Confirmation or in a separate written charge of $1-1 / 2 \%$ per month or, if less, the maximum rate allowed by applicable law. Unless otherwise specifically set forth in the Order Confirmation or in a separat

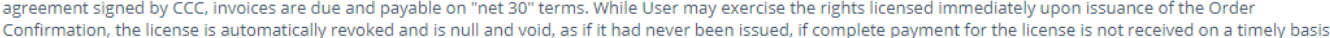
either from User directly or through a payment agent, such as a credit card company.

3.3. Unless otherwise provided in the Order Confirmation, any grant of rights to User (i) is "one-time" (including the editions and product family specified in the license), (ii) is nonexclusive and non-transferable and (iii) is subject to any and all limitations and restrictions (such as, but not limited to, limitations on duration of use or circulation) included in the Order Confirmation or invoice and/or in these terms and conditions. Upon completion of the licensed use, User shall either secure a new permission for further use of the Work(s) or immediately cease any new use of the Work(s) and shall render inaccessible (such as by deleting or by removing or severing links or other locators) any further copies of the Work (except for copies printed on paper in accordance with this license and still in User's stock at the end of such period).

3.4. In the event that the material for which a republication license is sought includes third party materials (such as photographs, illustrations, graphs, inserts and similar materials) which are identified in such material as having been used by permission, User is responsible for identifying, and seeking separate licenses (under this Service or otherwise) for, any of such third party materials; without a separate license, such third party materials may not be used. 
3.5. Use of proper copyright notice for a Work is required as a condition of any license granted under the Service. Unless otherwise provided in the Order Confirmation, a proper copyright notice will read substantially as follows: "Republished with permission of [Rightsholder's name], from [Work's title, author, volume, edition number and year of copyright]; permission conveyed through Copyright Clearance Center, Inc. " Such notice must be provided in a reasonably legible font size and must be placed either mmediately adjacent to the Work as used (for example, as part of a by-line or footnote but not as a separate electronic link) or in the place where substantially all other cedits or notices for the the Work as ther fees and charges specified.

3.6. User may only make alterations to the Work if and as expressly set forth in the Order Confirmation. No Work may be used in any way that is defamatory, violates the rights of third parties (including such third parties' rights of copyright, privacy, publicity, or other tangible or intangible property), or is otherwise illegal, sexually explicit or obscene. In addition, User may not conjoin a Work with any other material that may result in damage to the reputation of the Rightsholder. User agrees to inform CCC if it becomes aware of any infringement of any rights in a Work and to cooperate with any reasonable request of C८C or the Rightsholder in connection therewith.

4. Indemnity. User hereby indemnifies and agrees to defend the Rightsholder and CCC, and their respective employees and directors, against all claims, liability, damages, costs and expenses, including legal fees and expenses, arising out of any use of a Work beyond the scope of the rights granted herein, or any use of a Work which has been altered in any unauthorized way by User, including claims of defamation or infringement of rights of copyright, publicity, privacy or other tangible or intangible property.

5. Limitation of Liability. UNDER NO CIRCUMSTANCES WILL CCC OR THE RIGHTSHOLDER BE LIABLE FOR ANY DIRECT, INDIRECT, CONSEQUENTIAL OR INCIDENTAL DAMAGES (INCLUDING WITHOUT LIMITATION DAMAGES FOR LOSS OF BUSINESS PROFITS OR INFORMATION, OR FOR BUSINESS INTERRUPTION) ARISING OUT OF THE USE OR INABILITY TO USE A WORK, EVEN IF ONE OF THEM HAS BEEN ADVISED OF THE POSSIBILITY OF SUCH DAMAGES. In any event, the total liability of the Rightsholder and CCC (including their respective employees and directors) shall not exceed the total amount actually paid by User for this license. User assumes full liability for the actions and omissions of its principals, employees, agents, affiliates, successors and assigns.

6. Limited Warranties. THE WORK(S) AND RIGHT(S) ARE PROVIDED "AS IS". CCC HAS THE RIGHT TO GRANT TO USER THE RIGHTS GRANTED IN THE ORDER CONFIRMATION DOCUMENT. CCC AND THE RIGHTSHOLDER DISCLAIM ALL OTHER WARRANTIES RELATING TO THE WORK(S) AND RIGHT(S), EITHER EXPRESS OR IMPLIED, INCLUDING WITHOUT LIMITATION IMPLIED WARRANTIES OF MERCHANTABILITY OR FITNESS FOR A PARTICULAR PURPOSE. ADDITIONAL RIGHTS MAY BE REQUIRED TO USE ILLUSTRATIONS, GRAPHS, PHOTOGRAPHS, ABSTRACTS, INSERTS OR OTHER PORTIONS OF THE WORK (AS OPPOSED TO THE ENTIRE WORK) IN A MANNER CONTEMPLATED BY USER; USER UNDERSTANDS AND AGREES THAT NEITHER CCC NOR THE RIGHTSHOLDER MAY HAVE SUCH ADDITIONAL RIGHTS TO GRANT.

7. Effect of Breach. Any failure by User to pay any amount when due, or any use by User of a Work beyond the scope of the license set forth in the Order Confirmation and/or these terms and conditions, shall be a material breach of the license created by the Order Confirmation and these terms and conditions. Any breach not cured within 30 days of written notice thereof shall result in immediate termination of such license without further notice. Any unauthorized (but licensable) use of a Work that is terminated immediately upon notice thereof may be liquidated by payment of the Rightsholder's ordinary license price therefor; any unauthorized (and unlicensable) use that is not terminated immediately for any reason (including, for example, because materials containing the Work cannot reasonably be recalled) will be subject to all remedies available at law or in equity, but in no event to a payment of less than three times the Rightsholder's ordinary license price for the most closely analogous licensable use plus Rightsholder's and/or CCC's costs and expenses incurred in collecting such payment.

8. Miscellaneous,

8.1. User acknowledges that CCC may, from time to time, make changes or additions to the Service or to these terms and conditions, and CCC reserves the right to send notice to the User by electronic mail or otherwise for the purposes of notifying User of such changes or additions; provided that any such changes or additions shall not apply to permissions already secured and paid for.

8.2. Use of User-related information collected through the Service is governed by ccC's privacy policy, available online here: https://marketplace.copyright.com/rs-uiweb/mp/privacy=policy

8.3. The licensing transaction described in the Order Confirmation is personal to User. Therefore, User may not assign or transfer to any other person (whether a natural person or an organization of any kind) the license created by the Order Confirmation and these terms and conditions or any rights granted hereunder; provided, however, that User may assign such license in its entirety on written notice to $\mathrm{CCC}$ in the event of a transfer of all or substantially all of User's rights in the new material which includes the Work(s) licensed under this Service.

8.4. No amendment or waiver of any terms is binding unless set forth in writing and signed by the parties. The Rightsholder and CCC hereby object to any terms contained in any writing prepared by the User or its principals, employees, agents or affiliates and purporting to govern or otherwise relate to the licensing transaction described in the Order Confirmation, which terms are in any way inconsistent with any terms set forth in the Order Confirmation and/or in these terms and conditions or CCC's standard operating procedures, whether such writing is prepared prior to, simultaneously with or subsequent to the Order Confirmation, and whether such writing appears on a copy of the Order Confirmation or in a separate instrument.

8.5. The licensing transaction described in the Order Confirmation document shall be governed by and construed under the law of the State of New York, USA, without regard to the principles thereof of conflicts of law. Any case, controversy, suit, action, or proceeding arising out of, in connection with, or related to such licensing transaction shall be brought, at CCC's sole discretion, in any federal or state court located in the County of New York, State of New York, USA, or in any federal or state court whose geographical jurisdiction covers the location of the Rightsholder set forth in the Order Confirmation. The parties expressly submit to the personal jurisdiction and venue of each such federal or state court.If you have any comments or questions about the Service or Copyright Clearance Center, please contact us at 978-750-8400 or send an e-mail to info@copyright.com. 


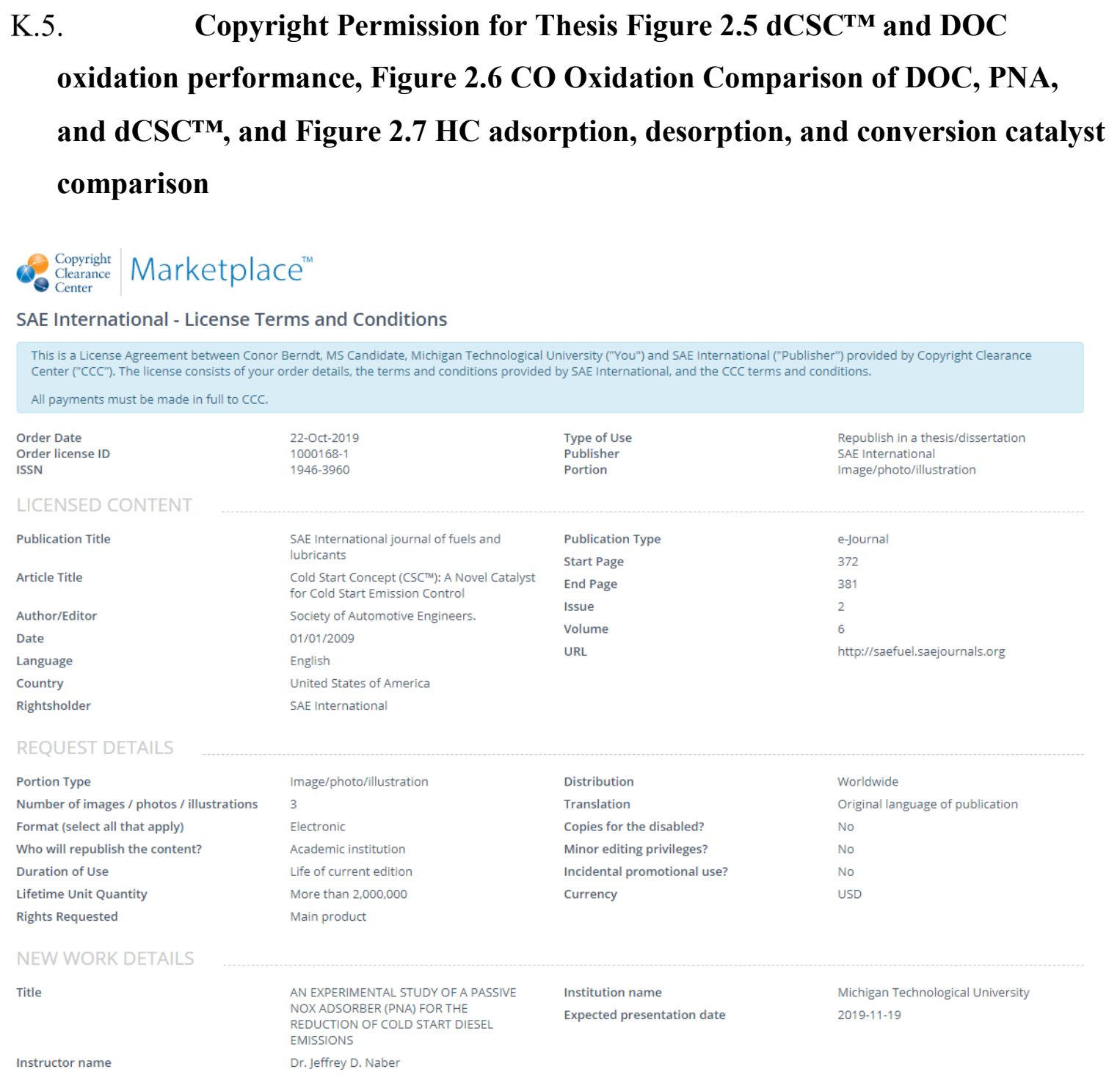


The requesting person / organization to appear on the license
Conor Berndt, MS Candidate, Michigan Technological University

\section{REUSE CONTENT DETAILS}

Title, description or numeric reference of the portion(s)

Editor of portion(s)

Volume of serial or monograph

Page or page range of portion
Figures 6,7 , and 8 .

Chen, Hai-Ying; Mulla, Shadab; Weigert, Erich: Camm, Kenneth: Ballinger. Todd Cox, Julian: Blakeman, Phil 372-381
Title of the article/chapter the portion is from

Author of portion(s)

Issue, if republishing an article from a

serial

Publication date of portion
Cold Start Concept (CSC'M): A Novel Catalyst for Cold Start Emission Control Chen, Hai-Ying; Mulla, Shadab; Weigert Erich: Camm, Kenneth; Ballinger, Todd: Cox, Julian: Blakeman, Phil 2

2013-04-08

\section{Republication Terms and Conditions}

1. Description of Service; Defined Terms. This Republication License enables the User to obtain licenses for republication of one or more copyrighted works as described in detail on the relevant Order Confirmation (the "Work(s)"). Copyright Clearance Center, Inc. ("CCC") grants licenses through the Service on behalf of the rightsholder identified on the Order Confirmation (the "Rightsholder"). "Republication", as used herein, generally means the inclusion of a Work, in whole or in part, in a new work or works, also as described on the Order Confirmation. "User", as used herein, means the person or entity making such republication.

2. The terms set forth in the relevant Order Confirmation, and any terms set by the Rightsholder with respect to a particular Work, govern the terms of use of Works in connection with the Service. By using the Service, the person transacting for a republication license on behalf of the User represents and warrants that he/she/it (a) has been duly authorized by the User to accept, and hereby does accept, all such terms and conditions on behalf of User, and (b) shall inform User of all such terms and conditions. In the event such person is a "freelancer" or other third party independent of User and CCC, such party shall be deemed jointly a "User" for purposes of these terms and conditions. In any event, User shall be deemed to have accepted and agreed to all such terms and conditions if User republishes the Work in any fashion.

3. Scope of License; Limitations and Obligations.

3.1. All Works and all rights therein, including copyright rights, remain the sole and exclusive property of the Rightsholder. The license created by the exchange of an Order Confirmation (and/or any invoice) and payment by User of the full amount set forth on that document includes only those rights expressly set forth in the Order Confirmation and in these terms and conditions, and conveys no other rights in the Work(s) to User. All rights not expressly granted are hereby reserved.

3.2. General Payment Terms: You may pay by credit card or through an account with us payable at the end of the month. If you and we agree that you may establish a standing account with CCC, then the following terms apply: Remit Payment to: Copyright Clearance Center, 29118 Network Place, Chicago, IL 60673-1291. Payments Due: Invoices are payable upon their delivery to you (or upon our notice to you that they are available to you for downloading). After 30 days, outstanding amounts will be subject to a service charge of 1-1/2\% per month or, if less, the maximum rate allowed by applicable law. Unless otherwise specifically set forth in the Order Confirmation or in a separate written agreement signed by CCC, invoices are due and payable on "net 30" terms. While User may exercise the rights licensed immediately upon issuance of the Order Confirmation, the license is automatically revoked and is null and void, as if it had never been issued, if complete payment for the license is not received on a timely basis either from User directly or through a payment agent, such as a credit card company.

3.3. Unless otherwise provided in the Order Confirmation, any grant of rights to User (i) is "one-time" (including the editions and product family specified in the license), (ii) is nonexclusive and non-transferable and (iii) is subject to any and all limitations and restrictions (such as, but not limited to, limitations on duration of use or circulation) included in the Order Confirmation or invoice and/or in these terms and conditions. Upon completion of the licensed use, User shall either secure a new permission for further use of the Work(s) or immediately cease any new use of the Work(s) and shall render inaccessible (such as by deleting or by removing or severing links or other locators) any further copies of the Work (except for copies printed on paper in accordance with this license and still in User's stock at the end of such period). 
3.4. In the event that the material for which a republication license is sought includes third party materials (such as photographs, illustrations, graphs, inserts and similar materials) which are identified in such material as having been used by permission, User is responsible for identifying, and seeking separate licenses (under this Service or otherwise) for, any of such third party materials; without a separate license, such third party materials may not be used.

3.5. Use of proper copyright notice for a Work is required as a condition of any license granted under the Service. Unless otherwise provided in the Order Confirmation, a proper copyright notice will read substantially as follows: "Republished with permission of [Rightsholder's name], from [Work's title, author, volume, edition number and year of copyright]; permission conveyed through Copyright Clearance Center, Inc. " Such notice must be provided in a reasonably legible font size and must be placed either immediately adjacent to the Work as used (for example, as part of a by-line or footnote but not as a separate electronic link) or in the place where substantially all other credits or notices for the new work containing the republished Work are located. Failure to include the required notice results in loss to the Rightsholder and CcC, and the User shall be liable to pay liquidated damages for each such failure equal to twice the use fee specified in the Order Confirmation, in addition to the use fee itself and any other fees and charges specified.

3.6. User may only make alterations to the Work if and as expressly set forth in the Order Confirmation. No Work may be used in any way that is defamatory, violates the rights of third partles (including such third parties' rights of copyright, privacy, publicity, or other tangible or intangible property), or is otherwise illegal, sexually explicit or obscen In addition, User may not conjoin a Work with any other material that may result in damage to the reputation of the Rightsholder. User agrees to inform CCC if it becomes aware of any infringement of any rights in a Work and to cooperate with any reasonable request of CCC or the Rightsholder in connection therewith.

4. Indemnity. User hereby indemnifies and agrees to defend the Rightsholder and CCC, and their respective employees and directors, against all claims, liability, damages, costs and expenses, including legal fees and expenses, arising out of any use of a Work beyond the scope of the rights granted herein, or any use of a Work which has been altered in any unauthorized way by User, including claims of defamation or infringement of rights of copyright, publicity, privacy or other tangible or intangible property.

5. Limitation of Liability. UNDER NO CIRCUMSTANCES WILL CCC OR THE RIGHTSHOLDER BE LIABLE FOR ANY DIRECT, INDIRECT, CONSEQUENTIAL OR INCIDENTAL DAMAGES (INCLUDING WITHOUT LIMITATION DAMAGES FOR LOSS OF BUSINESS PROFITS OR INFORMATION, OR FOR BUSINESS INTERRUPTION) ARISING OUT OF THE USE OR INABILITY TO USE A WORK, EVEN IF ONE OF THEM HAS BEEN ADVISED OF THE POSSIBILITY OF SUCH DAMAGES. In any event, the total liability of the Rightsholder and CCC (including their respective employees and directors) shall not exceed the total amount actually paid by User for this license. User assumes full liability for the actions and omissions of its principals, employees, agents, affiliates, successors and assigns.

6. Limited Warranties. THE WORK(S) AND RIGHT(S) ARE PROVIDED "AS IS". CCC HAS THE RIGHT TO GRANT TO USER THE RIGHTS GRANTED IN THE ORDER CONFIRMATION DOCUMENT. CCC AND THE RIGHTSHOLDER DISCLAIM ALL OTHER WARRANTIES RELATING TO THE WORK(S) AND RIGHT(S), EITHER EXPRESS OR IMPLIED, INCLUDING WITHOUT LIMITATION IMPLIED WARRANTIES OF MERCHANTABILITY OR FITNESS FOR A PARTICULAR PURPOSE. ADDITIONAL RIGHTS MAY BE REQUIRED TO USE ILLUSTRATIONS, GRAPHS, PHOTOGRAPHS, ABSTRACTS, INSERTS OR OTHER PORTIONS OF THE WORK (AS OPPOSED TO THE ENTIRE WORK) IN A MANNER CONTEMPLATED BY USER; USER UNDERSTANDS AND AGREES THAT NEITHER CCC NOR THE RIGHTSHOLDER MAY HAVE SUCH ADDITIONAL RIGHTS TO GRANT.

7. Effect of Breach. Any failure by User to pay any amount when due, or any use by User of a Work beyond the scope of the license set forth in the Order Confirmation and/or these terms and conditions, shall be a material breach of the license created by the Order Confirmation and these terms and conditions. Any breach not cured within 30 days of written notice thereof shall result in immediate termination of such license without further notice. Any unauthorized (but licensable) use of a Work that is terminated immediately upon notice thereof may be liquidated by payment of the Rightsholder's ordinary license price therefor; any unauthorized (and unlicensable) use that is not terminated immediately for any reason (including, for example, because materials containing the Work cannot reasonably be recalled) will be subject to all remedies available at law or in equity, but in no event to a payment of less than three times the Rightsholder's ordinary license price for the most closely analogous licensable use plus Rightsholder's and/or CCC's costs and expenses incurred in collecting such payment.

8. Miscellaneous.

8.1. User acknowledges that CCC may, from time to time, make changes or additions to the Service or to these terms and conditions, and CCC reserves the right to send notice to the User by electronic mail or otherwise for the purposes of notifying User of such changes or additions; provided that any such changes or additions shall not apply to permissions already secured and paid for.

8.2. Use of User-related information collected through the Service is governed by CCC's privacy policy, available online here: https://marketplace.copyright.com/rs-uiweb/mp/privacy=policy.

8.3. The licensing transaction described in the Order Confirmation is personal to User. Therefore, User may not assign or transfer to any other person (whether a natural person or an organization of any kind) the license created by the Order Confirmation and these terms and conditions or any rights granted hereunder; provided, however, that User may assign such license in its entirety on written notice to $\mathrm{CCC}$ in the event of a transfer of all or substantially all of User's rights in the new material which includes the Work(s) licensed under this Service.

8.4. No amendment or waiver of any terms is binding unless set forth in writing and signed by the parties. The Rightsholder and Ccc hereby object to any terms contained in any writing prepared by the User or its principals, employees, agents or affiliates and purporting to govern or otherwise relate to the licensing transaction described in the Order Confirmation, which terms are in any way inconsistent with any terms set forth in the Order Confirmation and/or in these terms and conditions or CCC's standard operating procedures, whether such writing is prepared prior to, simultaneously with or subsequent to the Order Confirmation, and whether such writing appears on a copy of the Order Confirmation or in a separate instrument.

8.5. The licensing transaction described in the Order Confirmation document shall be governed by and construed under the law of the State of New York, USA, without regard to the principles thereof of conflicts of law. Any case, controversy, suit, action, or proceeding arising out of, in connection with, or related to such licensing transaction shall be
brought, at CCC's sole discretion, in any federal or state court located in the County of New York, State of New York, USA, or in any federal or state court whose geographical jurisdiction covers the location of the Rightsholder set forth in the Order Confirmation. The parties expressly submit to the personal jurisdiction and venue of each such federal or state court. If you have any comments or questions about the Service or Copyright Clearance Center please contact us at 978-750-8400 or send an e-mail to info@copyright.com.

$\mathrm{v} 1.1$ 


\section{K.6. Copyright Permissions for Thesis Figure 2.8 200-Second dCSC}

\section{NOx Storage Capacity}

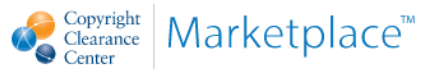

SAE International - License Terms and Conditions

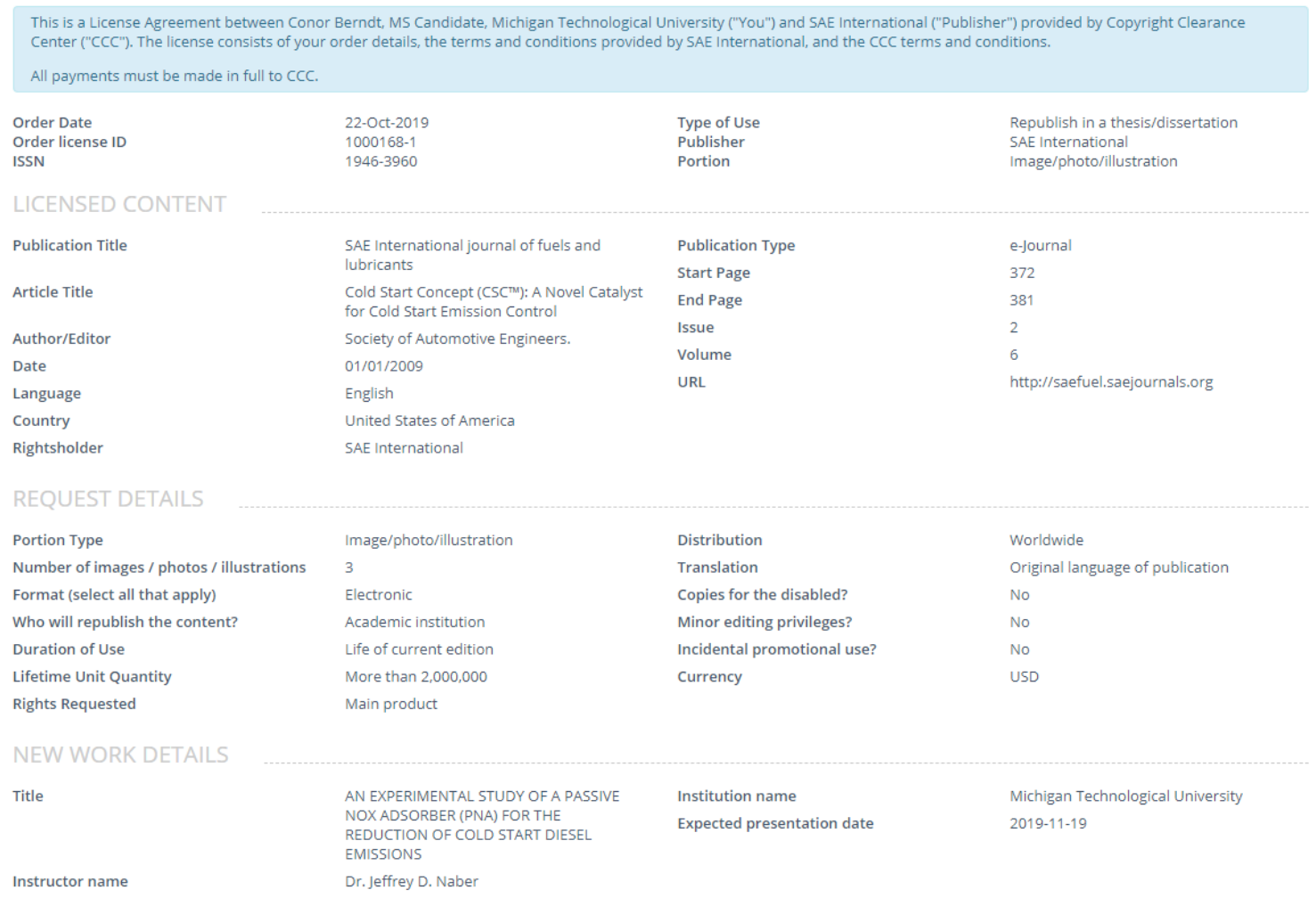


The requesting person / organization to appear on the license
Conor Berndt, MS Candidate, Michigan Technological University

\section{REUSE CONTENT DETAILS}

Title, description or numeric reference of the portion(s)

Editor of portion(s)

Volume of serial or monograph

Page or page range of portion
Figures 6,7 , and 8 .

Chen, Hai-Ying; Mulla, Shadab; Weigert, Erich: Camm, Kenneth: Ballinger. Todd Cox, Julian: Blakeman, Phil 372-381
Title of the article/chapter the portion is from

Author of portion(s)

Issue, if republishing an article from a

serial

Publication date of portion
Cold Start Concept (CSC'M): A Novel Catalyst for Cold Start Emission Control Chen, Hai-Ying; Mulla, Shadab; Weigert Erich: Camm, Kenneth; Ballinger, Todd: Cox, Julian: Blakeman, Phil 2

2013-04-08

\section{Republication Terms and Conditions}

1. Description of Service; Defined Terms. This Republication License enables the User to obtain licenses for republication of one or more copyrighted works as described in detail on the relevant Order Confirmation (the "Work(s)"). Copyright Clearance Center, Inc. ("CCC") grants licenses through the Service on behalf of the rightsholder identified on the Order Confirmation (the "Rightsholder"). "Republication", as used herein, generally means the inclusion of a Work, in whole or in part, in a new work or works, also as described on the Order Confirmation. "User", as used herein, means the person or entity making such republication.

2. The terms set forth in the relevant Order Confirmation, and any terms set by the Rightsholder with respect to a particular Work, govern the terms of use of Works in connection with the Service. By using the Service, the person transacting for a republication license on behalf of the User represents and warrants that he/she/it (a) has been duly authorized by the User to accept, and hereby does accept, all such terms and conditions on behalf of User, and (b) shall inform User of all such terms and conditions. In the event such person is a "freelancer" or other third party independent of User and CCC, such party shall be deemed jointly a "User" for purposes of these terms and conditions. In any event, User shall be deemed to have accepted and agreed to all such terms and conditions if User republishes the Work in any fashion.

3. Scope of License; Limitations and Obligations.

3.1. All Works and all rights therein, including copyright rights, remain the sole and exclusive property of the Rightsholder. The license created by the exchange of an Order Confirmation (and/or any invoice) and payment by User of the full amount set forth on that document includes only those rights expressly set forth in the Order Confirmation and in these terms and conditions, and conveys no other rights in the Work(s) to User. All rights not expressly granted are hereby reserved.

3.2. General Payment Terms: You may pay by credit card or through an account with us payable at the end of the month. If you and we agree that you may establish a standing account with CCC, then the following terms apply: Remit Payment to: Copyright Clearance Center, 29118 Network Place, Chicago, IL 60673-1291. Payments Due: Invoices are payable upon their delivery to you (or upon our notice to you that they are available to you for downloading). After 30 days, outstanding amounts will be subject to a service charge of 1-1/2\% per month or, if less, the maximum rate allowed by applicable law. Unless otherwise specifically set forth in the Order Confirmation or in a separate written agreement signed by CCC, invoices are due and payable on "net 30" terms. While User may exercise the rights licensed immediately upon issuance of the Order Confirmation, the license is automatically revoked and is null and void, as if it had never been issued, if complete payment for the license is not received on a timely basis either from User directly or through a payment agent, such as a credit card company.

3.3. Unless otherwise provided in the Order Confirmation, any grant of rights to User (i) is "one-time" (including the editions and product family specified in the license), (ii) is nonexclusive and non-transferable and (iii) is subject to any and all limitations and restrictions (such as, but not limited to, limitations on duration of use or circulation) included in the Order Confirmation or invoice and/or in these terms and conditions. Upon completion of the licensed use, User shall either secure a new permission for further use of the Work(s) or immediately cease any new use of the Work(s) and shall render inaccessible (such as by deleting or by removing or severing links or other locators) any further copies of the Work (except for copies printed on paper in accordance with this license and still in User's stock at the end of such period). 
3.4. In the event that the material for which a republication license is sought includes third party materials (such as photographs, illustrations, graphs, inserts and similar materials) which are identified in such material as having been used by permission, User is responsible for identifying, and seeking separate licenses (under this Service or otherwise) for, any of such third party materials; without a separate license, such third party materials may not be used.

3.5. Use of proper copyright notice for a Work is required as a condition of any license granted under the Service. Unless otherwise provided in the Order Confirmation, a proper copyright notice will read substantially as follows: "Republished with permission of [Rightsholder's name], from [Work's title, author, volume, edition number and year of copyright]; permission conveyed through Copyright Clearance Center, Inc. " Such notice must be provided in a reasonably legible font size and must be placed either immediately adjacent to the Work as used (for example, as part of a by-line or footnote but not as a separate electronic link) or in the place where substantially all other credits or notices for the new work containing the republished Work are located. Failure to include the required notice results in loss to the Rightsholder and CcC, and the User shall be liable to pay liquidated damages for each such failure equal to twice the use fee specified in the Order Confirmation, in addition to the use fee itself and any other fees and charges specified.

3.6. User may only make alterations to the Work if and as expressly set forth in the Order Confirmation. No Work may be used in any way that is defamatory, violates the rights of third partles (including such third parties' rights of copyright, privacy, publicity, or other tangible or intangible property), or is otherwise illegal, sexually explicit or obscen In addition, User may not conjoin a Work with any other material that may result in damage to the reputation of the Rightsholder. User agrees to inform CCC if it becomes aware of any infringement of any rights in a Work and to cooperate with any reasonable request of CCC or the Rightsholder in connection therewith.

4. Indemnity. User hereby indemnifies and agrees to defend the Rightsholder and CCC, and their respective employees and directors, against all claims, liability, damages, costs and expenses, including legal fees and expenses, arising out of any use of a Work beyond the scope of the rights granted herein, or any use of a Work which has been altered in any unauthorized way by User, including claims of defamation or infringement of rights of copyright, publicity, privacy or other tangible or intangible property.

5. Limitation of Liability. UNDER NO CIRCUMSTANCES WILL CCC OR THE RIGHTSHOLDER BE LIABLE FOR ANY DIRECT, INDIRECT, CONSEQUENTIAL OR INCIDENTAL DAMAGES (INCLUDING WITHOUT LIMITATION DAMAGES FOR LOSS OF BUSINESS PROFITS OR INFORMATION, OR FOR BUSINESS INTERRUPTION) ARISING OUT OF THE USE OR INABILITY TO USE A WORK, EVEN IF ONE OF THEM HAS BEEN ADVISED OF THE POSSIBILITY OF SUCH DAMAGES. In any event, the total liability of the Rightsholder and CCC (including their respective employees and directors) shall not exceed the total amount actually paid by User for this license. User assumes full liability for the actions and omissions of its principals, employees, agents, affiliates, successors and assigns.

6. Limited Warranties. THE WORK(S) AND RIGHT(S) ARE PROVIDED "AS IS". CCC HAS THE RIGHT TO GRANT TO USER THE RIGHTS GRANTED IN THE ORDER CONFIRMATION DOCUMENT. CCC AND THE RIGHTSHOLDER DISCLAIM ALL OTHER WARRANTIES RELATING TO THE WORK(S) AND RIGHT(S), EITHER EXPRESS OR IMPLIED, INCLUDING WITHOUT LIMITATION IMPLIED WARRANTIES OF MERCHANTABILITY OR FITNESS FOR A PARTICULAR PURPOSE. ADDITIONAL RIGHTS MAY BE REQUIRED TO USE ILLUSTRATIONS, GRAPHS, PHOTOGRAPHS, ABSTRACTS, INSERTS OR OTHER PORTIONS OF THE WORK (AS OPPOSED TO THE ENTIRE WORK) IN A MANNER CONTEMPLATED BY USER; USER UNDERSTANDS AND AGREES THAT NEITHER CCC NOR THE RIGHTSHOLDER MAY HAVE SUCH ADDITIONAL RIGHTS TO GRANT.

7. Effect of Breach. Any failure by User to pay any amount when due, or any use by User of a Work beyond the scope of the license set forth in the Order Confirmation and/or these terms and conditions, shall be a material breach of the license created by the Order Confirmation and these terms and conditions. Any breach not cured within 30 days of written notice thereof shall result in immediate termination of such license without further notice. Any unauthorized (but licensable) use of a Work that is terminated immediately upon notice thereof may be liquidated by payment of the Rightsholder's ordinary license price therefor; any unauthorized (and unlicensable) use that is not terminated immediately for any reason (including, for example, because materials containing the Work cannot reasonably be recalled) will be subject to all remedies available at law or in equity, but in no event to a payment of less than three times the Rightsholder's ordinary license price for the most closely analogous licensable use plus Rightsholder's and/or CCC's costs and expenses incurred in collecting such payment.

8. Miscellaneous.

8.1. User acknowledges that CCC may, from time to time, make changes or additions to the Service or to these terms and conditions, and CCC reserves the right to send notice to the User by electronic mail or otherwise for the purposes of notifying User of such changes or additions; provided that any such changes or additions shall not apply to permissions already secured and paid for.

8.2. Use of User-related information collected through the Service is governed by CCC's privacy policy, available online here: https://marketplace.copyright.com/rs-uiweb/mp/privacy=policy.

8.3. The licensing transaction described in the Order Confirmation is personal to User. Therefore, User may not assign or transfer to any other person (whether a natural person or an organization of any kind) the license created by the Order Confirmation and these terms and conditions or any rights granted hereunder; provided, however, that User may assign such license in its entirety on written notice to $\mathrm{CCC}$ in the event of a transfer of all or substantially all of User's rights in the new material which includes the Work(s) licensed under this Service.

8.4. No amendment or waiver of any terms is binding unless set forth in writing and signed by the parties. The Rightsholder and Ccc hereby object to any terms contained in any writing prepared by the User or its principals, employees, agents or affiliates and purporting to govern or otherwise relate to the licensing transaction described in the Order Confirmation, which terms are in any way inconsistent with any terms set forth in the Order Confirmation and/or in these terms and conditions or CCC's standard operating procedures, whether such writing is prepared prior to, simultaneously with or subsequent to the Order Confirmation, and whether such writing appears on a copy of the Order Confirmation or in a separate instrument.

8.5. The licensing transaction described in the Order Confirmation document shall be governed by and construed under the law of the State of New York, USA, without regard to the principles thereof of conflicts of law. Any case, controversy, suit, action, or proceeding arising out of, in connection with, or related to such licensing transaction shall be
brought, at CCC's sole discretion, in any federal or state court located in the County of New York, State of New York, USA, or in any federal or state court whose geographical jurisdiction covers the location of the Rightsholder set forth in the Order Confirmation. The parties expressly submit to the personal jurisdiction and venue of each such federal or state court. If you have any comments or questions about the Service or Copyright Clearance Center please contact us at 978-750-8400 or send an e-mail to info@copyright.com.

$\mathrm{v} 1.1$ 